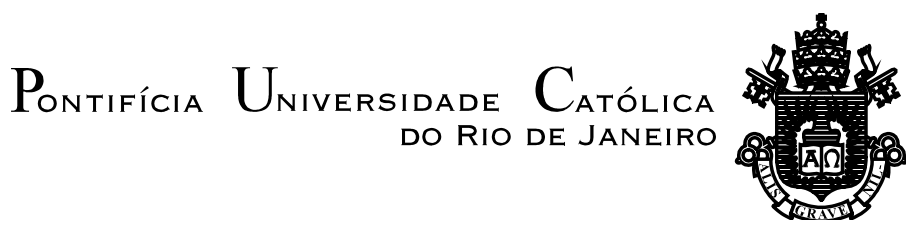

Sueli Rios e Silva

\title{
EXPERIMENTO DE AUTOFICÇÃO
}

\section{Dissertação de Mestrado}

Dissertação apresentada ao Programa de PósGraduação em Literatura, Cultura e Contemporaneidade da PUC-Rio como requisito parcial para obtenção do título de Mestre em Letras/Literatura, Cultura e Contemporaneidade.

Orientadora: Profa. Marília Rothier Cardoso 


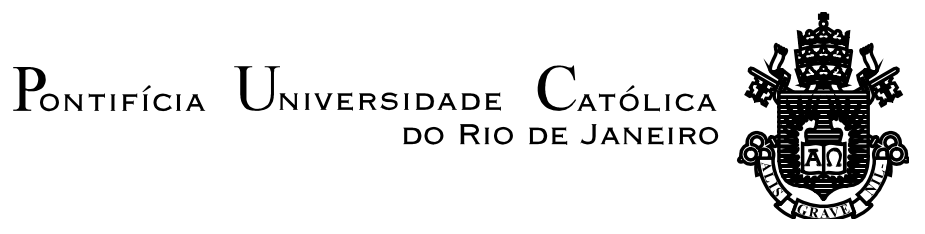

Sueli Rios e Silva

\title{
EXPERIMENTO DE AUTOFICÇÃO
}

Dissertação apresentada como requisito parcial para obtenção do grau de Mestre pelo Programa de PósGraduação em Literatura, Cultura e Contemporaneidade do Departamento de Letras do Centro de Teologia e Ciências Humanas da PUCRio. Aprovada pela Comissão Examinadora abaixo assinada.

\author{
Profa. Marilia Rothier Cardoso \\ Orientadora \\ Departamento de Letras - PUC-Rio
}

Profa. Ana Paula Veiga Kiffer

Departamento de Letras - PUC-Rio

Profa. Maria Teresa Ferreira Bastos

UFRJ

Profa. Denise Berruezo Portinari

Coordenadora Setorial do Centro de Teologia

e Ciências Humanas - PUC-Rio

Rio de Janeiro, 05 de abril de 2013. 
Todos os direitos reservados. É proibida a reprodução total ou parcial do trabalho sem a autorização da universidade, da autora, e da orientadora.

\section{Sueli Rios e Silva}

Graduou-se em Direito pela Universidade Cândido Mendes-Ipanema (UCAM) e em Letras pela Pontifícia Universidade Católica do Rio de Janeiro (PUC-Rio). Publicou o livro de contos Não foi por acaso, 7Letras, 2010. Foi premiada no "Concurso Machado de Assis (1908-2008)", realizado pelo Departamento de Letras da PUC-Rio e pela Globo Universidade, com o ensaio "Variando com Machado", (3 $3^{\circ}$ lugar). Foi uma das vencedoras do IV Concurso Crônica e Literatura: prêmio literário Adélia Prado, com a crônica "Isso... e muito mais", In--Veredas Literárias, org. Ivone Gomes de Assis, Uberlândia: Assis, 2011. Contribuiu com o poema "Lobacho" para Antologia Vozes da Paisagem II, org. Marcia Pereira, Rio de Janeiro, Galo Branco, 2011. É autora do poema "Mensagem de aniversário", publicado no Jornal "Diário de Catalão" e de vários poemas publicados no jornal literário "Plástico Bolha", do Rio de Janeiro. Concluiu o Mestrado em Literatura Cultura e Contemporaneidade (PUC-Rio) em 2012. Atualmente cursa o Doutorado em Literatura Cultura e Contemporaneidade na (PUC-Rio).

\section{Ficha Catalográfica}

Silva, Sueli Rios e

Experimento de autoficção / Sueli Rios e Silva ; orientadora: Marília Rothier Cardoso. - 2013.

250 f. ; $30 \mathrm{~cm}$

Dissertação (mestrado)-Pontifícia Universidade Católica do Rio de Janeiro, Departamento de Letras, 2013.

Inclui bibliografia

1. Letras - Teses. 2. (Auto)Fiç̧ão. 3. Fabulação. 4. Memórias de infância. 5. Autoria. 6. Geografia do cerrado goiano. 7. Tradições de catalão. I. Cardoso, Marília Rothier. II. Pontifícia Universidade Católica do Rio de Janeiro. Departamento de Letras. III. Título. 
Para Marília, orientadora competente, cuidadosa, firme, confiável, sensível, que perpassou cada palavra deste trabalho com a luz constante e generosa do seu alto conhecimento e olhar de estrela guia, endireitando a rota e evitando que eu me perdesse pelo caminho, até o fim da travessia. 


\section{Agradecimentos}

A Marília Rothier Cardoso pela paciência, zelo, confiança e força que me infundiu desde a graduação até a coroação do Mestrado.

A Ana Kiffer pela riqueza do seu conhecimento que anda de mãos dadas com sua intuição aguda e deixou pegadas visíveis neste trabalho.

Aos professores da graduação e da pós-graduação pelos ensinamentos que me trouxeram até aqui.

A Daniele, Francisca e Digerlaine pela presteza e cortesia.

Aos meus filhos, Rickson e Roney, pelo estímulo incondicional.

Ao meu cunhado Wiliam Caixeta, ao Professor João Martins e ao Dr. João Sebba, pelas contribuições nas pesquisas.

Ao meu velho amigo José Antonio pelas boas conversas sobre fatos históricos.

Ao meu jovem amigo Lucas Viriato pelo apoio contínuo.

Aos colegas pelo firme incentivo.

A Marilena Moraes pela disponibilidade constante.

À Pontifícia Universidade Católica do Rio de Janeiro e, em especial, à ViceReitoria de Assuntos Acadêmicos da instituição, pela concessão da Bolsa VRAC, que permitiu a isenção das taxas escolares durante o período do meu curso de mestrado. 


\section{Resumo}

Silva, Sueli Rios e; Cardoso, Marília Rothier. Experimento de Autoficção. Rio de Janeiro, 2013. 250p. Dissertação de Mestrado - Departamento de Letras, Pontifícia Universidade Católica do Rio de Janeiro.

Este trabalho é composto por duas partes distintas e complementares: a primeira apresenta o romance autoficcional Menina do Cerrado, colagem de resíduos da memória e da fabulação criativa engendrada especialmente para a presente composição. A segunda agrega um posfácio com considerações sobre elementos de cunho prático-teórico que alicerçam a ficção. A união das duas partes realça o esforço de fazer a aproximação de percepções artísticas a determinados conceitos da filosofia recente.

\section{Palavras-chave}

(Auto)Ficção; Fabulação; Memórias de infância; Autoria; Geografia do cerrado goiano; Tradições de Catalão. 


\section{Abstract}

Silva, Sueli Rios e; Cardoso, Marília Rothier (Advisor). Self-fiction Experiment. Rio de Janeiro, 2013. 250p. MSc. Dissertation - Departamento de Letras, Pontifícia Universidade Católica do Rio de Janeiro.

This work consists of two distinct but complementary sections: the first presents the auto-fictional novel Menina do Cerrado (The Girl from the Cerrado), a collage of bits of memories and the creative figment specially designed for this composition. The second one adds an afterword with considerations about practical and theorectical elements which support the fiction. Both parts together highlight the application of approaching artistic perceptions and some concepts of new philosophy.

\section{Keywords}

(Self) Fiction, Figment; Childhood Memories; Authorship; Geography of Cerrado; Vegetation of the State of Goiás; Traditions of Catalão. 


\section{Sumário}

1. Menina do Cerrado

2. Referências Bibliográficas

3. Autocrítica

234

4. Referências Bibliográficas 


\section{1 \\ Menina do Cerrado}

\section{1}

$\mathcal{L} a_{\text {vem a menina subindo a rua afogueada na volta para casa depois da }}$ correria do pique-esconde. Diminui os passos. Aproxima-se do retângulo iluminado de mansinho.

Para e fica vendo a avó sentada sozinha na sala conduzindo com habilidade sua agulha de ponta em gancho. No rosto de pele clara e quase sem rugas de Vó Mina, o alheamento de quem seleciona retalhos na arca da memória. Abarrotada. A neta na porta não pensa nisso. Claro. Tem apenas dez anos. Pouco sabe de certos assuntos. Para ela a figura da mulher à meia distância no silêncio da noite naquela posição meio curvada com os olhos perdidos no trabalho não é outra senão... Penélope! Cenas do filme que assistira havia pouco tempo no Cine Real desfilam sucessivamente pela sua cabeça e trazem a heroína... tecendo de dia... desmanchando de noite... refazendo ao amanhecer... desfazendo ao entardecer... A vovó não desmancha... Leva sempre adiante o seu crochezinho... Se o trabalho dela fosse um só, acho que já daria até pra cobrir o campo do CRAC $^{1}$ com ele. Ela é meio Penélope então... Coitada da vovó... O Ulisses dela não vai mais voltar...

- Ah, Luise, você chegou.

- Vem cá, Vó. Tá correndo uma aragem deliciosa, aqui fora.

Sorriso esboçado. Trabalho posto na mesa. Passos para a porta. Abraçada pela brisa fresca trazendo do cerrado o cheiro do pequi maduro, a mulher inspira com força e parece satisfeita por encher os pulmões com o ar friinho. Desliza as

\footnotetext{
${ }^{1}$ Clube Recreativo Atlético Catalano.
} 
mãos pelos braços cruzados e deixa o olhar passear pela rua deserta. Casas quase todas adormecidas. Apenas uma ou outra luz acesa.- A meninada toda já entrou?

- Na quaresma é assim, Vó, as mães nem precisam chamar. Cada um tem um caso pra contar... Aconteceu não sei com quem... Histórias de mula-semcabeça... Lobisomem... Todo mundo entra cedo e fica essa calma.

Oops! Calma aparente... Sertão incerto. Superfície lisa de rio de locas profundas... Redemoinhos... Labirintos... Catalão. Sudeste goiano. Divisa com Minas Gerais. Cidade por muito tempo situada longe da capital. Distante do comando do governo goiano, quatro dias a cavalo. Fora da jurisdição das decisões administrativas do governo mineiro. "Gente diferente", diziam os forasteiros que lá apareciam. "Povo com identidade própria". "Marcante". "Nem goianos nem mineiros: Catalanos." Lugar por muito tempo regido por leis próprias. O "Código de Catalão." Pendengas maiores picadas à faca ou estraçalhadas à bala. A gente tem fama de braba. $\mathrm{O}$ adjetivo varonil no hino. Há mais coisa no entre da noitedia do que a inexperiência supõe... Numa noite "calma", assim, a terra seca vermelha embebe o sangue do poeta arrancado da cadeia e esfaqueado no meio da rua. Noutra igual, o bêbado barrado no baile na semana anterior, volta trazendo a cascavel, abre a boca do saco, dá o safanão violento e arremessa a víbora pela porta no meio do salão. O povo raleia. Dançando miudinho. Em mais uma noite parecida, o sanfoneiro escapa, no intervalo, mata o assassino do cunhado e volta furtivamente para continuar a tocar como se não tivesse saído dali. Em muitas de outros tempos, o chefe do executivo, revólver em punho, perambula pelas ruas com a turma, apostando atirar nas poucas lâmpadas existentes para mandar trocar no dia seguinte e quebrar noutra noite qualquer.

Histórias viajam. Nas falas. Nas lendas. Nos livros. Que o diga, os do escritor Bernardo Guimarães, juiz na cidade, por duas vezes. Fora do expediente, o juiz-escritor escrevia sua literatura. Fez da cidade, cenário de romance. Criou personagem, inspirado em tipos daqui. Relacionava com as pessoas sem preconceito. Tanto podia agachar em volta da fogueira, fumar cachimbo ou cigarro de palha, escutando crimes contados pelos próprios facínoras e aconselhando a eles muita prudência, porque "a justiça poderia tomar conhecimento daquilo". Quanto podia sair pelas ruas com outros intelectuais soltando a voz nas primeiras serenatas que a cidade ouviu. A menina observadora 
começa a ficar intrigada com certas conversas... "Quem está sendo cogitado para ter o oco atochado de pimenta?" "O nome de quem é costurado em boca de sapo?" Na calada da hora, armação de vingança, urdidura de tocaia... No recolhimento, ruminar de enredo, futrica de travesseiro... E na charqueada, é hora da matança... Num repente, sintomas de desejo e de paixão inflamada, irrompem cavalgando o vento:
Abra a porta ou a janela
Venha ver quem é que eu sou
Sou aquele desprezado
E foi você quem desprezou. ${ }^{2}$

A viola chora. A voz clama.

— Bonito demaais, né, Vó?

O olhar desvia. A cabeça sacode a resposta. - Daquele lado, Luise, o céu parece até mais pesado. - Rosto perscrutado. Brilho de lágrima? A dúvida estoca o pequeno coração. Perturba o momento de respiro da menina que desde pequena não tem vidinha muito fácil.

— Lá, a primeira estrela... Bem alta.

- Sabe que é a que mais tempo fica no céu, a que mais brilha, Vó? Diz que realiza desejo que nem a cadente. No finzinho da tarde, quando sozinha, a gente recita: 'Primeira estrela que vejo, me dá tudo que desejo' e faz pedido. Olha o Cruzeiro do Sul ali... Bem na direção do meu dedo. Até a Intrometida, sempre apagadinha, tá exibida.

— Lua nova... Céu mais escuro...

- Se a lua empana estrelas... Pode imaginar quanta coisa o sol pode embaçar? É esquisito pensar que a luz esconde coisas... Cadê as Três-marias?

O corpinho rodopiando... O indicador espetando o ar... "Lá... Lá... Lá elas, Vó! Entusiasmo contagia. Entremostra dentes fortes marfim. Alegre, vovó parece mais nova. Devia poder rir mais... Fragmentos de conversa, entreouvidos aqui e

\footnotetext{
${ }^{2}$ Estrofe de canção sertaneja.
} 
acolá, fazem a neta começar a compreender que a avó tem motivos fortes para não afrouxar o riso. $\mathrm{O}$ ensimesmar. $\mathrm{O}$ exame das mãos espalmadas.

- É verdade que apontar estrelas faz nascer verruga nos dedos?

— Pura invenção. Escuto essa bobagem, desde que tinha sua idade.

- O povo inventa tanta coisa, né... Falar que o Zecão é tarado... Acredita, Vó? Deve ser mentira. É tio da Delzita e...

A avó coloca as mãos na cintura e chega mais perto.

— O que é verdade... O que é mentira... Quem é que sabe? 'Onde tem fumaça costuma ter fogo.' Você já é uma mocinha, e todo "coidado" é pouco. A Pitida também tá crescendo... 'É melhor prevenir do que remediar'. Vou alertar sua mãe. Ela foi colocar os meninos na cama e, pela hora, decerto já dormiu, também. É tarde. Vamos entrar.

Porta taramelada. Trabalho sendo ajeitado para ser guardado.

- Pra quem é esse crochê?

- É parte da encomenda do enxoval da filha da D. Carmem.

— Desenho lindo... Faz igual pra mim?

- Decerto, faço, um dia. É cedo pra pensar em coisas de enxoval. Não passa de uma menina.

Ai-Ai... De novo isso! Há pouco, lá fora... "Você já é uma mocinha." Aqui, agora... "Você não passa de uma menina". A Mãe faz a mesma coisa: uma hora... "Luise desça já dessa árvore, uma moçona dessas, com efeito!" Fala assim mesmo... "Mo-ço-na!" Fico danada da vida! Outra hora... “Cinema de noite não pode, é muito menina ainda.” Ai, que raiva!

— As minhas amigas já começaram...

— A gente não tem que ficar imitando os outros, tem? Se alguém quiser cair no buraco, vai querer cair junto?

\section{Hoje nada dá certo... Inferno!}


J'ouviu, Luise?

- Ouvi, ouvi!

Engole a raiva. Tem motivos de sobra para gostar da avó.

- Queria ver de novo o retrato de casamento dos meus pais. A Mãe ficou linda de noiva. Fez muita coisa bonita pra ela?

Uma mudança gradual tarda a resposta, operando efeitos no velho rosto emoldurado pelos finos cabelos apanhados em coque ralo: a seriedade dando lugar ao endurecimento, os olhos virando buraquinhos encravados, o semblante sendo velado pelo véu da tristeza - Mal se conheceram e inventaram aquele casamento.

As palavras proferidas em tom baixo e seco parecem arrastadas pelo fio de voz, passando por entre as linhas estreitas dos lábios pesadas como tijolos.

- 'Quem come depressa, come cru'. O dito popular arremata a conversa —Venha, vou fechar a cozinha.

No ar do ambiente o aroma não deixa dúvidas... A mãe torrou café. Pousado no rabo do fogão o torrador novo para confirmar. É melhor aprender a lidar logo com isso. Girar manivela é mais fácil do que mexer panela e receber a quentura do fogo até os grãos ganharem a cor certa do ponto. Sem descuidar um minuto. Pra não virar carvão. Esse torrador lembra o escafandro do filme do mergulhador... A bola é grande... Cabe boa quantidade... É só abrir a portinhola... Ui! Ainda tá quen...

- Pra cama, Luise. 
Noite clara. Muito clara. Lua enorme luando coisas ao redor... Pedaços da rua... Lados das casas... Pontas dos quintais... Nesgas dos pastos... Cadê as pessoas? Ninguém perto... Ninguém longe... Nem de um lado... Nem do outro. Coisa esquisita! Eu aqui fora sozinha no meio da noite fazendo o quê? Onde foi parar todo mundo? Ah, tem um vulto lá perto da charqueada... Nem apertando os olhos desse jeito, consigo ver quem é... É um homem. Agora tá virando pra cá... Ai! Deus do Céu! A cabeça é de lobo... O lobisomem! O quêêê... O lobisomem é o Zecão!? Ai-ai-ai... Ele já me viu e vem vindo pra cá... Ai-ai-ai... Preciso fugir depressa! Ahn... Minhas pernas não saem do lugar? Parecem grudadas no chão! Preciso correr [Socorro] Ahn...[Socorro!] [Socorro!] Senhor! Nããão... Quero gritar... [Vó!]... Não posso... [Vóóó!]... Minha voz também tá presa! Vóóóó!!! Vóóóó!!!

— Luise! Acorda, Luise! Eu tô aqui, filha.

$$
3
$$

Luise precisa andar muito para chegar à escola. Sai de casa cedo. Poucas pessoas na rua. Quase todas entrando ou saindo da venda do Seu Zé Alvarino... Atrás do pãozinho de cada dia... Uns querem mais moreninhos... Outros mais branquinhos... Vovó, sempre os mais clarinhos... Às vezes, acho com gosto de cru. A um terço da caminhada, resolve dobrar à esquerda. Menos por ser o caminho mais direto e mais pela certeza de que as trombetas brancas estarão lá, acenando por cima do muro. Passa e dá... Tchau! ...para as flores da beladona. Desce. Alcança a paralela embaixo. Na esquina da Rua do Pio, o verdureiro apóia o pé no degrau do sobradinho e suporta o jacá na coxa, esperando com a maior paciência do mundo, a freguesa escolher...alface, almeirão, salsa, cebolinha, 
couve, abobrinha, jiló, tomate, pepino quiabo... Como são fresquinhas as verduras do japonês!

Cresce o toc-toc das passadas apressadas. Aumenta o frufru das pregas azulmarinho, agilmente movimentadas. Multiplica o número de brancas mangas trêsquartos, abraçadas a livros e cadernos. Magotes de mocinhas entram sob o arco do portão no qual está escrito Colégio Nossa Senhora Mãe de Deus, com as letras acompanhando sua forma arqueada. Galgam os degraus da pequena escadaria e desaparecem pela porta escancarada. Na parede acima dela, o altaneiro emblema da escola é ostentado em alto relevo. Diz que depois dessa entrada tem um esqueleto ... Verdade... Invenção... Não sei. Só sei que deve ser muito bom estudar aí... Aprender canto... Dança... Muitas filhas de fazendeiros estudam e moram internas. Entrei aquela vez, com a Mãe... Não por essa porta. Era aniversário da escola... Que festa! Todo mundo podia assistir... Passamos pelo portão... Ficamos na balaustrada que dá pro pátio interno... Mais me encantou ver a 'A Dança das Flores', representada pelas alunas embaixo... Linda demais! Duas mocinhas passam quase correndo. Luise também aperta o passo. Vence as quadras que ainda faltam, passando pela cadeia, pelo pé de cajazinho, dobrando à esquerda e dando mais alguns passos. Pronto. Engolfa no burburinho familiar dos rapazinhos do ginásio, meninas e meninos da escola paroquial, no pátio do São Bernardino de Siena, esbanjando movimento... Uniforme marrom... Bando de rolinhas. Subindo a escadaria frontal, a menina vê o cordão franciscano dançar de um lado para o outro, no topo. Irmã Paulita atravessa o patamar apressada, sininho na mão. Logo está postada no alto, brandindo vigorosamente a sineta e alinhando o primário ao pé da escada lateral. Luise, na fila embaixo, observa a freira comandar a oração... Que nem santa em altar ...e depois instigar a cantoria... "Happy birthday to you..." Abris bocas! Abris bocas!" Faz explodir o eco das "maritacas."

\author{
Happy birthday to you \\ Happy birthday to you \\ Happy birthday to Frei Benício \\ Happy birthday to you \\ May The Dear Lord bless you \\ May The Dear Lord bless you \\ May The Dear Lord Bless Frei Benício \\ Happy birthday to You
}


Braços esticados. Dedos fechando e abrindo... "Abris bocas... Abris bocas!" Os gestos da freira expressam melhor o que quer dos alunos... "Abris bocas... Abris bocas!" Sotaque carregado. Mistura das línguas. "Open bocas... Abris bocas! The birthday is next week. "Para homenagear o diretor do Curso Ginasial no dia do aniversário, a diretora da Escola Paroquial faz os alunos decorarem a canção. "Happy birthday to Frei Benício". Persiste. "I would like a perfect surprise." "Happy birthday to You." A missa também é repetição de papagaios... Dominus Vobiscum et Espíritum tuuum... Aaaamééém... "Good job. Entrando now. Devagar, quiet!"

$\mathrm{Na}$ sala, uma reza mais. Começa a aula. Primeiras noções de fração. "Na figura um, a fruta inteira." Luise, livro aberto sobre a carteira, admira os desenhos de pequeninas maçãs... Pra todos os gostos, inteiras, fatiadas, reunidas, separadas... A maçã é um encanto! E o cheirinho então? Quando passo lá na frente da venda do $\mathrm{Sr}$ Nicolau, dou sempre uma espiadinha no caixote... Manzanas... Outro dia, vi quando desenrolou o macio papel de seda roxo, tirou uma bem vermelhinha, segurou pelas pontas dos dedos e exibiu pra freguesa... "Da Argentina" ...huumm! "Na figura dois a fruta aparece partida. Observem que são duas partes exatamente iguais. No desenho três podem ver que duas meias maçãs juntas, formam fruta inteira. Então, meia maçã, mais meia maçã é igual..." A lição estimula a lembrança da menina a refazer certo episódio... Duas meninas... Uma maçã... Meia pra cada uma devia ser... Tinha que ser! Até hoje, tenho raiva das bizarrias da Tita naquele dia. Primeira vez que ia lá em casa. A Mãe convidou. Filha do Sr. Esteves não queria que o pai, viúvo, casasse de novo. Zombeteira e discordante, a tarde inteira... Na hora de ir embora... Pendurou num braço da Mãe e a Mãe me puxou pelo outro pra ir junto. Precisava? Lá ia eu firmemente segura de um lado, e a nojentinha agarrada no outro. Morava numa casa da colônia da charqueada, com o pai, os dois irmãos e a avó. Não era perto. No meio do caminho, começou de 
repente a dar pulinhos e a soltar grunhidinhos. Muito esquisito. Eu não sabia que fazia aquilo pra chamar minha atenção. Curiosa. Bobona. Mordi a isca. Mesmo presa, joguei o corpo pra frente e consegui olhar pra ela. Era o que queria. Fazia sinal com o olhar indo e vindo de mim para a mão da Mãe, na qual andava pendurada. Guiava a minha vista. Vi. Vermelha. Inconfundível. Mal encoberta pelos dedos da Mãe, a maçã! Levantei os olhos. Seguia séria. Olhava pra frente. Não devolveu o olhar. Baixei a cabeça. Não passei recibo. Do outro lado, pararam as estripulias. Disfarcei até o fim. Fiz de conta que não vi a vitória estampada na cara da capetinha quando se despediu, virou as costas e foi embora com o mimo. Maçãs custam caro. Vêm da Argentina. A fruta-do-lobo bem podia ser maçã. É tão parecida. O lobo-guará ia gostar? Será que a macieira é tão bonita quanto a lobeira? Folhas aveludadas... Flores violetas... Tantas no cerrado... Tomara um dia plantem maçãs no Brasil... Já pensou? Cestas cheiiinhas... Comer quantas quisesse... Delícia maior haveria de ser? Um dia quem sabe... A gente vai poder até fazer doce... A torta que faz a mãe do Hans e do Fritz, na revistinha..." Os sobrinhos do Capi..."

— Luise, venha ao quadro fazer essa operação.

- Hã!?

— Não sabe. Também, "voando" desse jeito, como vai poder entender qualquer explicação? Ah, mas vai aprender, copiando a frase: "Devo prestar atenção à aula." Duzentas linhas. Pra segunda-feira. Sem falta! Duzentas... Passar o fim de semana inteiro copiando linha... Inferno!

A jornada continua depois do recreio. Aula de religião. Luise procura no livro a lição anunciada pela Irmã Maria. No alto de uma folha, vê o desenho do grande olho emitindo raios em direção ao pé da página e fica como se hipnotizada. Lembra palavras da freira um dia... "Não esqueçam que Deus tudo vê." Mal ouve o que diz agora... "Para criar o ser humano, o Deus criador de todas as coisas moldou primeiro o homem à sua imagem e semelhança, chamou de Adão. Depois, tirou uma costela dele pra fazer a mulher a quem deu o nome de Eva. Deixou os dois livres no Paraíso, proibindo apenas que comessem o fruto da macieira..." Macieira? A palavra faz a menina reagir ao magnetismo do olho emissor de 
raios. A árvore da maçã! Será possível que hoje só se fala nisso? Passa a folhear o livro rapidamente. Encontra a página. Nela está desenhada uma serpente enrolada no tronco de uma árvore carregada de frutos, lançando um olhar esquisito para uma mulher com a cabeleira enorme cobrindo o corpo dela até os pés. Ao seu lado tem um homem com olhos postos no chão, ar envergonhado e arrependido. "Tentada pelo demônio em forma de serpente, Eva não resistiu, comeu a fruta do pecado e ainda deu para o Adão. Fruta do pecado, a maçã!? Gostosa do jeito que é... Ah, não pode ser. “Os Mistérios de Deus se dividem em três grupos..." Irmã Maria passa a falar dos Mistérios da Fé. Luise se envereda pelos mistérios da vida... Naquele dia, quando a Mãe deu a maçã pra filha... Queria mesmo era dar pro pai. “...Dolorosos, Gloriosos e Gozosos...” A hora avança. O relógio... Triiiiiimmm! Fim da jornada. "Não se esqueçam da missa dominical!"

\section{5}

Luise desce a escadaria no meio da algazarra de muitas crianças... Passarinhada. A menina sai conversando com algumas coleguinhas. Na medida em que cada uma precisa tomar rumo certo de casa, o grupo vai se desfazendo. Primeira esquina, uma sobe a rua, as outras descem; segundo cruzamento, Luise dobrando à direita se despede das que seguem em frente... "Tchau" Na ida, a menina sempre meio apressada. Na volta, pode cismando livremente... Sempre que passo na porta dessa cadeia, o preso tá ali na janela. Deve ser horrível ver a vida enquadrada desse jeito... Escutar os passarinhos cantando perto e não poder ver... A não ser que um ou outro pouse naquele galho mais baixo do pé de cajazinho... O que será que aquele homem fez? Nesta rua 'passa boi, passa boiada' pra charqueada, rapazinhos pro São Bernardino, mocinhas pro Mãe de Deus, mulheres pra igreja, homens pro trabalho, enterro... E o preso ali. Vendo a vida da janela lateral... Marginal? E se for inocente? Diz que o Antero era. Coisa mais triste o sofrimento do poeta... Arrancado dessa cadeia... Empurrado à ponta de faca por esse caminho que 
espicha até a saída de Goiandira... Iiih, lá vem o Bastião Molafaca. Calça quase caindo... Umbigo de fora... Como sempre. Por que não ensinam a ele passar a correia por dentro e não por fora das presilhas? Diz que só fica brabo se alguém assobiar... Sei lá. A vovó diz que sempre tem um ou outro que gosta do mal feito. E se algum engraçadinho der um assobio de zunir, só pra azucrinar o Bastião... Já pensou? O coitado vai ficar fulo da vida... Pular pra cima... Xingar todo mundo de tudo quando é nome... É melhor não facilitar... Sabe de uma coisa? Vou procurar cajazinho e dar um tempo pra ele passar. Tenho medo e tenho dó... Do Molafaca... Do Lenheiro... Por que será que existe gente assim no mundo? 'Pagando pena na Terra', dizem alguns por aí. Será? A menina desvia para a cerca que separa a rua do grande quintal sombreado. Passa facilmente por baixo do arame farpado no ponto bambo de tanto ser levantado pelas mãozinhas ávidas da meninada atraída pelas irresistíveis frutinhas caídas de maduras. Entra e sai, contando com o beneplácito dos donos da casa, acostumados a ver da janela movimento no gramado deles, pintalgado sempre de pássaros bicando e de crianças bicotando as bolotinhas amarelas que se espalham pelo chão.

\section{6}

Depois de saborear alguns cajazinhos esperando o Molafaca passar, Luise volta para casa e vai direto para o quarto se desvencilhar dos objetos. Sobre o travesseiro encontra... A fotografia! Será que foi o Sr. Zé de Brito quem tirou? No retrato em preto e branco, o rapaz beira vinte anos, moreno, cabelos encaracolados, boca bem desenhada, lábios cheios, olhos escuros com um pequeno desvio que empresta a ele um ar de atrevido. Posando ao lado, a jovem de tez muito clara, pequeninas sardas pontilhando em volta do nariz bem feito, cabelos negros e fartos escorrendo pelos ombros adornados com singela grinalda de flores de laranjeiras, simbolizando com o vestido branco, virgindade, pureza da mocinha de dezesseis anos, então, verdadeiramente apaixonada. João e Joana... Encontraram por acaso? Tinha de acontecer de qualquer jeito? O meu pai 
vir lá do Maranhão encontrar a minha mãe aqui em Goiás... Coincidência? Não? Luise lembra reação da avó na noite anterior. A vovó é a melhor pessoa do mundo... Mas, às vezes, fala umas coisas... Quando pergunto pra entender, muda de assunto. A vida tem mistérios, que a gente não pode entender... Mas tem coisas que só parecem mistérios porque ficam escondidas. Eu queria saber coisas do meu pai... Não quer conversa sobre o assunto. Deixou a fotografia, sem falar nada... Por quê? Por quê?

Muitas respostas para as inquietações de Luise estão no passado dela... Passado... Que passado? Tem apenas dez anos. Melhor dizer talvez que a existência da menina está ligada a fatos graves que ela ainda desconhece. Alguns aconteceram quando a mãe era ela mesma pouco mais que criança e morava na pequena Goiandira emancipada da sede na qual a filha um dia viria nascer.

Catalão é cortada por duas paralelas: o Rio Pirapitinga e os trilhos do trem. Entre as duas linhas, o jardim bem plantado, coração da cidade. Nas proximidades, a área comercial, atraindo compradores, como Vó Mina, que às vezes vinha de trem com a filha fazer comprinhas na cidade maior. Saltavam na estação, atravessavam a linha, desciam a rua e logo ganhavam o centro. Luise sabe que numa dessas travessias os olhos de água-mel da mãe e os olhos estrábicos do pai se cruzaram... Por acaso? Ou tinha que ser assim mesmo? Alguma coisa selou os destinos dos dois? A menina não sabe o tamanho da contrariedade da avó com a filha e o desconhecido se olhando daquele jeito, na ocasião e a cada dia que tinha o desgosto de ouvir... "Ainda vou me casar com essa moça." As palavras soavam nos ouvidos dela como uma espécie de ameaça e tiravam a graça de tudo. Ponderações. Conselhos. Súplicas. Nada impediu o casamento. O novo casal passou a morar em Catalão, vivendo do pequeno comércio de frutas e hortaliças que João montou no largo da matriz. Joana logo engravidou. Deu à luz a um menino. Hélio. Morreu antes de completar o primeiro ano de vida. Sofrimento desabou. As costas de Vó Mina arqueando sob o fardo de 
ver a filha amadurecendo no sofrimento da perda. Um dia a esperança voltou. Joana esperava outra vez. Outro menino. Joston. Para quem duvidava que um raio pudesse cair duas vezes no mesmo lugar, a certeza. Caiu. O segundo filho do casal Joana-João não sobreviveu mais tempo do que o primogênito. De novo, o destino bateu neles com mão pesada. Sobrecarregou seus ombros cansados com o peso incomensurável do duplo luto. Sabendo que 'não adiantava chorar sobre leite derramado', Vó Mina não tirava da cabeça os pressentimentos que tivera antes da filha casar. Dias sucederam noites. Passaram semanas. Meses. Joana chorando suas lágrimas de sangue. Um dia as regras dela sumiram outra vez. A boa nova confirmada. A alegria não veio plena. Misturada com a ansiedade. Escoltada pela cautela. Mesmo depois da chegada da menininha a esse mundo, esperança e expectativa confundidas.

A boa localização do comércio de João favorecia a convivência com os moradores do centro. Dentre eles, escolhidos os padrinhos para a menininha. O respeitado dentista, Miguel Aziz e a mulher dele, Maria, o casal convidado para batizar Maria Luise. Maria porque, na ocasião, a igreja só batizava menina com o nome antecedido pelo da Mãe de Deus, Luise por sugestão da madrinha, apreciadora de nomes estrangeirados. O escrivão Antonio Rodovalho e sua mulher, Samya crismaram. Gatos-escaldados por duas vezes que eram, os pais cercando a menininha com o maior cuidado e desvelo. Primeiro aniversário. A mãe tentou experimentar sapatinhos novos. $\mathrm{O}$ grito infantil a fez recuar. Ao entrar em casa e saber da dor no dedo de um dos pezinhos, o pai reagiu. "Leva a menina ao Doutor!" A perda dos filhos, um atrás do outro, deixava os jovens pais inseguros, angustiados, sofridos. A luta deles parecia não ter fim. A providência imediata do atendimento. A competência do médico. $\mathrm{O}$ tratamento adequado. A dedicação do Doutor. Fatores determinantes na vida da menininha. Sem faltar ajuda dos santos. Claro. Todos, invocados pelos amigos e vizinhos prestativos. Benzeduras. Rezas. Promessas. Correntes de fé. E veio alívio. A menininha restabelecida. O acerto de contas. A partir dali, em cumprimento a promessa feita pela parteira dela, uma fogueira a ser acesa no dia de São João durante os anos de sua existência. Para facilitar o pagamento e evitar quebra do contrato, a experiente mulher estabeleceu uma cláusula preventiva, deixando claro para o Santo que o fogo poderia ser aceso até com sabugos de milho. A menininha venceu o primeiro ano. Saúde recobrada. Os pais mais aliviados. Todos pensando que a vida do 
casal caminharia tranquila, enfim. Até o dia que João fugiu de casa com a vizinha. "No meio de quem ajuda, há sempre quem atrapalha". "Joana mesma botou dentro de casa a cobra que haveria de picá-la." Ocupada demais naqueles dias difíceis para perceber que a mulher que recebia em casa e se fazia de prestativa, roubava o marido dela...

Sem poder mais ver os estrábicos amados, os olhos de mel azedavam, fitando os restos do sonho... O retrato do casamento... Os traços na filhinha...

Anos mais tarde, a menina ouviria da madrinha Maria, que o pai, naquela ocasião, antes de sumir para sempre passara na casa dela em Goiânia, e fizera um pedido: "Comadre, estou indo embora e não vou voltar mais, cuida da minha filha pra mim."

A alternativa de Joana, voltar para a casa da mãe. Naquela época, Vó Mina já morava em Catalão com o filho mais novo, Eurípedes. Os dois mais velhos eram sitiantes e estavam casados. Eufrísio e Odília viviam próximos a Formosa, cidade natal de Vó Mina. Zeca e Maria, nos arredores de Goiandira, onde os pais passaram a morar depois de casados, tiveram os filhos e fizeram as boas amizades que Vó Mina lá conserva. “Goiandira, Terra Branca!” Luise escuta a mãe suspirar sempre que a saudade da terra natal bate nela.

Muitos dizem: “Joana é a mais parecida com Eurípedes.” Próximo dos vinte anos, estatura mediana, corpo malhado pelo trabalho, pele alva da família, olhos e cabelos escuros. Bonito. Alegre. Espirituoso. Brincalhão. Nesse tio, a menininha encontrou substituto para o genitor fugido. Eurípedes não perdia chance de se mostrar pai verdadeiro. Dava colo. Mimava. Ensinava.

\footnotetext{
Meu limão

Meu limoeiro

Meu pé de jacarandá

Uma vez tindolelê

Outra vez tindolalá

Lá lá lá lá lá lá
} 
Lá lá lá lá lá lá ${ }^{3}$

Na vivência do quintal murado, a menininha crescia e aprendia a amar a terra. Ainda não se expressava com as palavras. Não precisava. Externava respeito na contemplação embevecida daquele mundo encantado... A profusão da folhagem... A alternância das cores... A exuberância da floração... No canteiro multicolorido, sabia que o girassol era rei. Flor preferida do Tio. Ainda não subia nas árvores. Sentava à sombra delas. Prestava atenção ao som do vento... Escutava passarinhos, cigarras... Observava a vida miúda - tatuzinho-bola, joaninha, centopéia, lagarta, minhoca, caramujo, borboleta azul, branca, preta, amarela... Fuxicava a terra. Sujava as mãos. Fazia arte. Algumas manguinhas caídas, poucos gravetos... Pronto... Rica dona de rebanhos de vaquinhas verdes. Um dia, grande descoberta. Meio escondida entre folhas... Baita melancia! Quis tirar. Mostrar ao Tio. O cabo grosso não partia. Precisava levar a fruta. Era a primeira. Ele ia gostar de ver. Puxou. Sentou. Puxou. Empurrou. Puxou... Nem assim. Tornou a empurrar... Puxar... Empurrar... O talo não saía! Persistiu. Puxando... Empurrando... Puxando... Empurrando... "Ai!" De repente cedeu. A fruta rolando para frente. A menininha caindo para trás. Levantou. Atarantada. Viu a bola verde lá embaixo. Foi pegar. Não dava jeito. Era pesada. Abaixou. Abraçou. Levantou. Desequilibrou. Em pé, com esforço. Caminhou devagar. Trôpega. Venceu a distância. Alcançou o terreiro. A mãe viu a cena. "Tirou a melancia verde?" Parou. "A fruta nem cresceu direito.” Desequilibrou de vez. "Seu tio não vai gostar nada disso." O peso insuportável. A fruta caiu. Rolou. Parou no lameiro. A sensação ficou. Oprimia o pequeno peito. Parecia fardo maior. O cansaço tomou conta dela. Cochilou. Pouco adiantou. Acordou. Não quis comer. Não voltou ao quintal. Esperou. O resto da tarde. Cara amuada. Foi à porta da rua, uma, duas vezes. Espiou. Não vinha, ainda. Deu a hora, chegou! Só ele tinha aquela voz. Botou meia carinha fora da porta. Um ombro junto com ela. Não correu para o abraço. Soubesse falar como gente grande, não precisaria. “Luise tá doente?" Transbordava dos lagos, alargados. "Por que tá triste desse jeito?" A mãe contou a proeza. O Tio só fez gargalhar. "Cadê o toicinho que tava

\footnotetext{
${ }^{3}$ Cantiga popular.
} 
aqui?” Erguida pelos braços fortes. Rodada pela sala. Tristeza enxotada. Alegria na carinha. A menininha voando leve, que nem os passarinhos, gorjeando lá fora.

Eurípedes trabalhava na fábrica de manteiga. A casa cheirava fartura sortida... Leite... Queijo... Creme fresco batido... Manteiga... Ele cuidava também da plantação do quintal. Empurrava um graveto aqui. Tirava uma folha seca ali. Arrancava uma praga lá.

A pouca terra retribuía variedade... Feijão... Pepino... Tomate... Jiló... Quiabo... Abóbora... "Lá vai o pé, alastrando e tomando o espaço que encontra." Ajeitava a estaca. "A ramagem de chuchu subiu a laranjeira e já tá passando pra jabuticabeira." Cuidava dos canteiros das flores e com o mesmo capricho tratava dos das verduras... Couve... Alface... Salsa... Cebolinha... Hortelã...

O tio ensinava. "Plantio tem tempo certo." Viração da tarde, redemoinho... "Ventos de outubro". Certo trinado... revoada de saúva... boop-boop de sapo. "Sinais marcados". Lua distanciada. "Planta de milho é na lua-nova." Trovão surdo seguido de relampejo, tempo mudado, chuva chamada. "Escuta só. Vem noite molhada." Domingo nublado. Lá o tio. Calça de tecido grosso, camisa listrada... "Milho é planta de enxada." Tac-Tac... Mão firme no cabo, golpeando a moitinha. Tac-Tac... Movimentos certeiros... Afastando o cascalho. Derrubando a praga. Lanceando a enxada. Tac-Tac... Que cheiro bom de mato! A terra revirada. O tio suado. Capanga a tiracolo. Abrindo covinhas. Entre uma fileira e outra, a distância devida. "Para as folhas se acomodarem no crescimento." Pausa. Apoiado no cabo do enxadão. Olhava para a menininha. "Boa semente é a garantia primeira da boa colheita." Perguntava: "Entende?" A cabeça dela sacudia, sim. "Entende nada... Ha-ha-ha... Não passa de uma menininha... "Menina dos olhos do Tio". Ha-ha-ha... Recomeçava. Tirava da capanga os grãos selecionados das melhores espigas da safra anterior. Semeava... "seis grãos na cova, quatro na regra, dois de quebra." Arrastava terra. Cobria os pingos dourados. Fazia montinhos. Pausa. "Quer ajudar?” A cabeça respondia: "Sim". "Vem.” Ela ia correndo. "Pisa firme. 
Calca bem o pé. Pra enxurrada não levar". Sapateava. Trabalho terminado. “Agora é esperar a chuva e o sol fazer o resto".

10

Um canudinho enrolado,

Amarelo-pálido,

Frágil, dourado, se levanta,

Cria a sustância,

Passa a verde.

Liberta-se. Enraiza* ${ }^{4}$

Numa bela manhã. “Tii, tii... Lá!” Como se bordado por mãos caprichosas, sem que ninguém estivesse vendo, o quintal salpicado. "Ha-ha-ha... Mais bonito que o tapete da sala do seu padrinho, que é das Arábias, heim... "Ha-ha-ha..." Canutilhos verdes. Relevo encantador. Milagre da vida. Pé de milho esfolha. Cresce. Encorpa. Encana. Apendoa. Desfralda bandeiras verdes. "He-he... Milharal!" Batalhão do Tiro de Guerra. Formado. Pronto para sair em marcha: "Marcha soldado, cabeça de papel, se não marchar direito, vai preso pro quartel." Acompanhando de perto o efeito da parceria do tio com a natureza, a menininha quase sempre a primeira a anunciar mudança no quintal. "O milho ganhou boneca!" Embonecamento. Perfume quente no ar. Desfile de mães orgulhosas, rebentos nos regaços. Variedade. Tempo de brincar. “Quer qual?” A mais gorda? A mais magra? Bonecas de milho. Elegantes nas roupas 0verdes de palha... Vestido. Túnica. Sobretudo. Diversidade. Cabelos bastos... Lavados pela chuva... Soltos ao vento... Despenteados... Curtos... Compridos. Verde... Vermelho... Amarelo... Roxo... Prateado... Graça múltipla da florada.. Cheiro bom! Tempo de brincar... Qual escolher? "Aquela! Aquela! Aquela!” Tempo de insistentes pedidos... "Amarra a fita no cabelo dela, amarra." Brincando. Crescendo. Aprendendo. Pendão ressecado... Boneca empinada na haste... Não é mais boneca é espiga, decidida. Uma ou outra, nem lá nem cá. No meio do caminho. Não resolvida. Cabelos secos... Milho granado. Pronto para ser colhido. Transformado.

\footnotetext{
${ }^{4}$ Trecho do "Poema do Milho", Poemas dos Becos de Goiás e Estórias Mais, da Cora Coralina
} 
Pamonha. Curau. Cozido. Assado, no braseiro da cozinha, na fogueira de São João.

\section{1}

Hoje, a quase senhorita Luise chega em casa com seu olfato apurado nos cheiros dos alimentos frescos e pode sentir o perfume do milho fresco ralado antes mesmo de entrar na cozinha, onde encontra a avó às voltas com a gamela de massa dourada.

- Curau ou pamonha, Vó?

- Curau.

Prato pronto em cima da trempe. Almoço quentinho estendido. A menina come com vontade. A avó espreme bocados da massa ralada num pano seco. Separa o bagaço. Leva o leite de milho ao fogo. Junta uma porção de açúcar e uma pitada de sal. Mexe com colher de pau. Luise acaba de almoçar. Quer ser de alguma serventia.

— Essa casca é pro Ducho?

- É sim. Não há comida que chegue pra aquele porco.

— O danadinho não rejeita nada.

- Por isso engorda depressa. Lembra como chegou aqui? O leitão mais magro e feio que já vi.

- Naquele dia, você falou que ia precisar de muita comida pra ficar gorducho, e o Ruiz apontou pra ele: "Ducho!" Pronto, o bicho tava batizado.

- Parece até que foi ontem, não parece...Ainda posso ver o dedo rechonchudo e a voz de quem mal começava falar pegar todo mundo de surpresa.

Luise recolhe a fibra. Aproveita e dá uma espiadinha dentro do tacho. A avó mexe e remexe com a colher de pau. O leite de milho ferve e engrossa sobre o fogo crepitante alimentado pela boa lenha do Lenheiro. 
- Como é que a gente sabe o ponto certo?

- É o ponto de um mingau grosso. Mas não pode ser demais. Tem que ficar macio depois de frio. Tremer na colher, na hora de comer. Com a prática, fica fácil.

- Curau é bom, mas prefiro pamonha... Huum... Água na boca só de pensar.

- Dia desses, encomendo milho que chegue. Curau a gente faz até com três "atios". Pamonha, você sabe, é preciso bem mais.

- Hum-hum... Vó... Deixa eu te explicar uma coisa... O certo é falar a-tilho e não "atio".

- A-ti-lho?

- Isso mesmo, atilho. Pensa na D. Quetita, que a senhora não esquece mais.

Com a menção da vizinha, Vó Mina balança a cabeça de um lado para o outro em branda censura. A neta disfarça o riso e sai baldeando a comida do Ducho.

Luise segue lembrando o tempo do milho fartamente colhido no quintal do tio. A gente não precisava comprar atilhos. A Vó tem razão, pamonha precisa de muitas espigas. Custosa de fazer! Aprendera vendo repetidas vezes. Na sua cabeça, imagens do passo a passo. Primeiro, cortar um rolete no pé de cada espiga, tentar soltar a palha sem rasgar, reservar as mais perfeitas. Às vezes, a gente abre a palha e encontra uma lagarta nojenta, morando na espiga... Eca! Depois, ralar o milho, passar parte da massa pela peneira grossa para eliminar a fibra e juntar só o leite de volta, para não ficar pesada e grosseira. Acrescentar uma colher de manteiga e uma pitada de sal. Dividir a massa, juntar o açúcar na parte da pamonha doce e ajustar o sal na outra. Empalhar é que são elas! Vê tantas vezes a avó fazer isso. Pega a palha reservada. Enrola em canudo. Dobra 
uma ponta. Obtém uma espécie de copo. Enche de massa. Coloca um generoso pedaço de queijo minas dentro. Faz cilindro igual. Encaixa sobre o primeiro. Amarra a pamonha pela cintura firmemente com uma tirinha de palha. Usando uma tira a mais pra marcar as de sal, vovó não confunde doce e salgada cozinhando juntas, no panelão d'água fervente. Cozidas em pouco tempo. Pescar, desatar num prato, sentir o cheirinho e se deliciar com o manjar dourado quentinho... O queijo minas derretendo... Huum... Bom demaais! A vovó deve achar que só sei fazer cozinhadinho ou doce de leite no meu tachinho de cobre... Qualquer dia, ainda faço surpresa pra ela.

Luise mal começa a despejar o conteúdo do balde, o porquinho já avança... roonc-roonc... Focinha. Mastiga de boca aberta. Barulhão danado. Sei muito bem no que esse come-come vai dar... Lembra o dia do tempo de menininha, acordada antes da hora por altas vozes e o roonc-roonc, desceu da caminha, atravessou o quarto, chegou à cozinha e da porta viu, o porco derrubado e imobilizado no chão do terreiro... $\mathrm{O}$ homem apoiado num joelho e debruçado sobre o animal com uma faca na mão... A mãe e a avó estavam lá... Outra mulher também... Alguma vizinha, decerto. Ninguém deu sinal de perceber a nova presença no cenário. Que diferença fazia ter ou não uma menina por perto? Coisa mais comum, um porco ou outro ser morto, num quintal ou noutro, como aquele estava sendo ali, naquela hora. $\mathrm{O}$ homem desferiu o golpe. O bicho pareceu triplicar forças. Escapou gritando. O rastro de sangue ficando no chão. Adiantou o quê? Perseguido. Capturado. Silenciado. O corpo aspergido com uma garrafa inteira de álcool. Fogo ateado. Cheiro de sapecado no ar. Sufocante. O porco levantado. Depositado no jirau. Ensaboado. Esfregado. Enxaguado. Talhado de cima a baixo. A barrigada escorrendo para o balde posicionado. Com seu trabalho terminado, o homem vai embora com o pagamento nas costas: um quarto do bicho. Os vizinhos mais chegados tinham carninha destinada. A ajudante, quinhão reservado. As três mulheres dividiam o trabalho, apenas começado. Uma descarnava. Separava. Temperava. Cozinhava. Outra usava uma vareta de bambu para virar tripas finas do avesso. Limpava. Lavava. Raspava. Punha de molho num balde cheio de caldo de limão vermelho. Preparava o sangue do chouriço. A terceira cortava toicinho. Fritava. Enchia grandes latas de querosene de banha. Guardava pedaços grandes de carnes cozidas dentro, para conservar e durar muito tempo. Serviço de dia inteiro. Cheiro de tempero por todo lado. A noite pegou as 
mulheres enchendo tripas cor de rosa com porções de carne picadinha temperada e misturada com pedacinhos de toicinho... Apertavam-soltavam-apertavamsoltavam... Empurrando os bocados de carne até esbarrar no nó antes dado numa das pontas. Com a tripa cheia, davam o nó de remate na outra ponta. Encher linguiça exige tempo. Paciência-paciência-paciência. As mulheres pareciam dispostas a entrar noite à dentro. Para a menininha, o longo dia estava terminado. Voltou para a cama com a cabeça cheia de lembranças armazenadas. Na manhã seguinte, acordou, levantou e foi até a cozinha. Mantas de carne, toicinho e linguiças pendiam do varal, lambidas pela fumaça que subia do fogão.

\section{3}

A mãe de Luise é a terceira dos quatro filhos do casal Isídio de Souza Naves e Mina de Souza Gordo. Ouvindo um dia o nome completo da avó, a menina meio séria e meio na brincadeira reage.

— Ah, não Vó, tem dó... Mina de Souza Gordo... Gordo... Sobrenome mais esquisito!

— Diz que é de Gordon... Um parente das estranjas... Houve uma época que vinha muita gente atrás do ouro, das pedras...

— Eu já estudei o Movimento de Expansão. Os bandeirantes vinham de São Paulo, buscar índios pra trabalhar, encontraram as riquezas e...

- Os antigos falavam num tal Bartolomeu...

- Bartolomeu Bueno da Silva

- Contavam que ele e os companheiros vieram guiados pelos montes, chegaram à beira do Paranaíba... Na época, um matagal só. Diz que os homens margearam até achar lugar que desse pra passar a vau, pisaram o chão goiano, bem perto daqui. Marcaram o lugar bom pra travessia fincando uma cruz de madeira, ali na Borda da Mata. Descansaram e 'pernas pra que te quero?' Adentraram o mato outra vez, enfrentando dificuldades pelo caminho e acharam 
lugar bom de pouso perto do Córrego do Almoço. Gostaram. Quiseram conservar. Quando se embrenharam de novo, desviando caminho pelo Espigão do Rio São Marcos até Mestre D'armas, a Planaltina de hoje, deixaram um dos capelães cuidando das roças. Padre espanhol. Alcunha de "Catalão". O lugar ficando conhecido "Sítio do Catalão."

- Ahá! Agora sei de onde veio o nome da nossa cidade. Os meninos não vão mais poder enrolar com aquela bobojada... Eles falam, Vó... Que vinha um tal Lão e o pai pela rua, cada qual com um saco de feijão. $O$ filho deixou cair o dele e ficou parado, cara de bobo, olhando pros grãos esparramados no chão, até o velho gritar: "Cata, Lão!"

- Ha-ha... Brincadeira deles.

- Eu sempre quis saber de onde veio esse nome.

- Os antigos contavam assim.

- Gosto das suas histórias... Aquela do pescador pobre que pegou um peixe grande e teve a sorte de achar uma pedra enorme de diamante dentro da barriga dele é uma das melhores... E a cruz de madeira? Tá lá na beira do Paranaíba?

- Foi levada pra Goiás Velho.

- Por que tirar a cruz daqui e levar pra lá?

- Iiih... Aquilo deu uma confusão danada... De um lado, o juiz dando a ordem pra levar... Do outro, advogado insistindo pra deixar aqui, escrevendo no Correio de Catalão que era um "marco histórico" importante nosso e devia ficar. Randolfo não teve o apoio necessário.

- Tiraram a cruz do lugar que o Anhanguera fincou, e povo permitiu?

- Política... Sabe como é... A questão tratada como disputa partidária... Quem dominava tirando proveito... A cabeça do povo confundida... Deixaram o marco algum tempo no cinema antigo, as pessoas iam assistir aos filmes mudos e podiam ver também a cruz escura lá. Um dia veio uma automotriz especialmente pra buscar. Foi num domingo... Fizeram festa... A banda de música tocando... Os foguetes espocando... As moças e os rapazes da fina flor da sociedade catalana carregando a cruz pra estação de trem... O tal juiz que deu a ordem pra levar pra Goiás Velho era de lá e trabalhava aqui.

— Ladrão de cruz!

— Luise, isso é lá jeito de falar? 
- Pensa bem, Vó... A Expansão Bandeirante em Goiás começou aqui, a cruz era nossa, ele mandou tirar e levar pra cidade dele... Tá bom Vó... Como foi que o Gordon virou Gordo?

- Escreveram errado no cartório. Acontece muito.

- Que sorte, a minha, escapar desse sobrenome esquisito. Meus colegas de escola... 'Luise Gordo, pra cá, Luise Gorda pra lá.' Já pensou? Ainda bem que tenho o sobrenome do meu pai.

"Pelo menos isso" A frase escorregou sussurrada entre dentes e logo a voz da avó volta ao tom normal.

— Do lado de cá, herdou os olhos.

- A D. Carmem diz que são cor de folha seca.

- Bonita cor.

- Acho esquisita.

— Diziam que os do seu avô Isídio eram cor de anil.

O tom do azul não é novidade para a menina. Sempre vê o quadradinho desmanchando e tingindo a água de enxaguar roupa branca. Do avô, que não conhecera, sabia o pouco que ouvira pela boca da avó. Voz rouca. Olhos rasos d'água. Dor renovada pela lembrança, contando para alguém certa vez... “A história do meu marido é a mesma de qualquer outro camponês que precisou trabalhar duro desde cedo, morou em muitos lugares, tendo sempre que procurar terra mais fértil. Ouviu dizer que aqui tudo que plantava dava. As melhores terras já tinham sido ocupadas. As terras boas não eram pra camponês. Os fazendeiros iam tomar. E iam armados. Isídio queria viver dignamente. 'Morrer de fome é 'desavergonha' pra quem sempre trabalhou duro.' Quando a gente se conheceu, trabalhava do jeito que fosse preciso: meeiro, posseiro, parceiro, assalariado... Não tinha garantia. A cada colheita, mal fazia pro gasto. A maleita era braba. Foi um pouco mais longe, procurando terra de cultura. Goiandira ainda distrito. Fazia a derrubada pra roça. O tronco caiu pelo lado imprevisto. Isídio imprensado. Eufrísio rapazinho ainda. Lembrou o pai dizendo da terra boa nos arredores de Formosa, onde eu tinha família. Meu filho resolveu ir prá lá. Conseguiu um pedaço de terra. Disposto a lutar pra defender o que conquistou com sacrifício que 
fosse preciso. Conheceu Odília. Juntou com a família dela, trabalhando muito. A intenção era levar todos nós. Nesse meio tempo, Zeca conheceu Maria, se assentou por aqui mesmo. Mais tarde Nenzinha casou, como sabe...." $\mathrm{Na}$ intimidade a filha Joana era chamada assim. Com a perda do companheiro Vó Mina precisou trabalhar muito para acabar de criar os filhos. De dia, quitanda para fora. De noite, crochê à luz de lamparina de querosene. Sonhava ver um dia todos casados. "Com gente de família boa, honesta, trabalhadora e não que se envolvesse com qualquer." Falava, às vezes, de um jeito... As palavras pareciam pular boca afora como se cuspisse pensamento aos pedaços... "Apareceu na cidade assentando dormentes na estrada de ferro." "Um aventureiro de olhos vesgos!" "Ninguém sabia ao certo de onde vinha."

— Quem, Vó?

- Sua mãe também tem olhos claros... Meio transparentes... Como o mais fino mel da flor do mata-pasto.

- Mata-pasto?

- Florinhas que tomam conta dos campos. Lá pra janeiro, quando a gente cata as últimas gabirobas já tão lá... Florescendo por todo lado... Até abril.

— Sei quais. São lindas. Não sabia o nome. Por que chamam mata-pasto?

- É erva daninha. Espalha por toda parte... Toma terrenos baldios, invade pastagens, lota beiras de estrada... Traz prejuízo pro gado.

— Vó, quando é mesmo o tempo certo da gabiroba?

- Floresce de setembro a novembro... As frutas maduram de outubro a dezembro.

— Já viu flor mais linda e delicada?

Luise cantarola: “Quebra, quebra gabiroba, eu quero ver quebrar, quebra lá que eu quebro cá, quero ver quebrar.”

- É melífera, também. Mel de gosto bom, cor bonita...

- Ai-Ai... O mel depende da abelha e da flor... Com tantas espécies, de uma e de outra... É preciso provar muito mel até saber qual o melhor. 
Luise escuta a mãe e a avó conversando. Conhece o tema. A saudade acumulada que Vó Mina sente do filho mais velho, morando longe e que há muitos anos não vê. Não entra na conversa dos mais velhos. Ouve o assunto rebatido, agora com uma novidade.

— Sei que é longe, mas, sabe como é... A idade chegando... Se não for $\operatorname{logo...~Posso~até~não~ir~mais.~}$

- Ah, mãe... Para com isso.

— Tudo é muito custoso. A comadre facilitou. Tenho que aproveitar.

- Ninguém melhor que a Madrinha pra compreender sua situação.

- Só que, no caso dela, coitada... Não pode nem pensar.

- Com essa carestia... Viajar pro estrangeiro... Não dá nem pra fazer ideia do dinheirão.

— Da última vez em Goiandira, só deu esse assunto. Ela no seu jeito de falar... "Saudades da minha terrinha, dos parentes que lá 'daixei." Não pensa voltar a morar lá... Que a essa altura da vida não seria louca de deixar a boa casinha e viver noutro lugar 'sem eira e nem beira'. Queria apenas rever a terrinha onde nasceu... "Pelo menos uma vez antes de morrer."

— Ela gosta daqui. Diz que os netos são 'brasilairos'.

— Eu falando da minha necessidade de ver o Eufrísio... Do dinheirinho que venho juntando e que para o ano... Não me deixou terminar. "Contigo é diferente. Viajar pra Formosa não é como ir a Portugal. Não podes comparar. Tua terra é logo ali. A gente tá ficando velha, comaadre... Não percas mais o teu tempo. Vá logo ver o teu menino!"

— Também não é assim, Mãe.

- Ela tá certinha, Nenzinha. Foi direto ao ponto das minhas preocupações. Quem é que sabe o dia de amanhã? Teve uma hora que ficou calada com aquele olho dela correndo de um lado para o outro...

\section{Como um bichinho querendo escapar do alçapão.}

... de repente, a ideia... "Tu sabes d'uma coisa? Meus parentes têm lá em Goiânia uma pensão. Tu pegas o trem, que vai pra Capital... Vais ter de fazer 
baldeação... Te hospedas com eles, por uns dias... Depois viaja de "jardinaira" pra tua terra. Ora, pois, pois, deixa comigo, que eu me arranjo com eles. Hoje mesmo, vou mandar o Augustinho escrever uma carta pra minha sobrinha Irene." Deu aquela piscada que você conhece e continuou. "Podes ficar sossegada, Comadre. Sabes como é... Gostas de trabalhar... És caprichosa... Podes dar uma mãozinha pra Irene na cozinha... Garanto que ela vai gostar"

- Posso até ver a Madrinha fechando o olho são e deixando só o outro todo branco aparecer.

- A ideia dela deu certo. Chegou a hora de ir. Mal posso acreditar.

- Sonha com essa viagem há tanto tempo.

- Estava pensando em levar a Luise.

— Ela já acabou as provas e vai logo entrar em férias... Não é Luise?

Pronto, já tô livre pra viajar com a vovó. Faltava só entregar o bordado da D. Odete. Ela foi tão boazinha, comigo... Mandou entrar... Apresentou a mãe... Ofereceu aquele doce... Diferente! Casca de bolo grossa, empapada de mel? Bom passaado!* ${ }^{5}$ Depois, a surpresa maior. Na hora da despedida, ao invés de caminhar para a porta que leva ao portão da rua... "Por aqui, Luise." Entrou na outra... Nooossa! Podia imaginar um dia ser convidada a ficar dentro do balcão da Casa Sultão, a melhor loja de tecidos da cidade? A D. Odete falou qualquer coisa com o pai dela, naquela língua enrolada deles e começou a futucar peças de panos nas prateleiras. $O$ velho voltou a dar atenção pra freguesa, e eu fiquei encostada no balcão, diante das três portas escancaradas, podendo ver tudo lá fora... As pessoas indo e vindo... O cruzamento das ruas... O largo... A Igreja do Rosário... Que maravilha deve ser ver a Festa dali... O levantamento do mastro... Os estandartes... N. Sra. do Rosário, São Benedito... O povo emocionado...

\footnotetext{
5 Expressão local.
} 
Barraquinhas vendendo tudo... $O$ rancho grande... $O$ alto-falante tocando música e mandando recado pros namorados... O correio-elegante... O pau-desebo com o dinheiro pendurado no alto, sempre com algum rapaz tentando subir e pegar... Quando a gente pensa que um vai conseguir... Sssssss... Lá vem escorregando e...

Buumm!...s'esparrama no chão todo lambuzado sem ter alcançado a nota. É custoso conseguir. Se fosse fácil qual a graça? Enfrentar a dificuldade... Vencer o desafio... Aumenta o valor do prêmio. E a procissão? Tantas velas acesas. O povo de roupa nova. Os tambores. Os Congos dançam... Abaixam, levantam, viram de um lado pro outro... Cada um dando o seu melhor. Fitas de toda cor bailando loucamente com os movimentos... Encanto de ver... E o barulhinho de longe ouvir... O que é, o que é... Começa a crescer de repente... Os Moçambiques... Claro. O que mais haveria de ser? Chocalhinhos amarrados aos tornozelos... tchique-tchique nas mãos... Encanto de escutar. O corpo todo acompanhando a marcha... Os pés parecendo conhecer a harmonia de cor... Que ritmo! De repente...

\section{- Obrigada! \\ - Olha o troco. \\ - Muito agradecida.}

Alheada e absorvida pela festa, Luise volta a si com a freguesa se despedindo e saindo. A professora dela ainda virando e revirando peças nas prateleiras. Agora, parece que resolveu... Tá pondo no balcão aquele bem alegrinho... Medindo... Cortando... Embrulhando...

— Toma Luise. Esse corte é pra você.

- Pra...?!

— Fala pra sua mãe fazer um vestido.

— Não precisava... D. Odete. 
Naquele dia, no fim da aula, a professora chamou Luise à mesa dela, com o pedaço de linho e as meadas na mão... "Pode bordar isso pra mim?" A menina ficou sem saber o que responder. Tive receio de não dar conta. $O$ risco era grande. Dava volta no quadrado inteiro. Parecia pedir até ponto cheio, talvez até rococó e sombra... Já tinha bordado um ou outro paninho de prato... pontoatrás... maria-preguiçosa... correntinha... Só. Mas não podia ir logo dizendo não pra D. Odete, sem pelo menos tentar. Não foi fácil. Passei bons apertos escolhendo as linhas, combinando as cores... No fim, acho que deu certo. Bom demais provar aquele doce gostoso, ganhar o estampado de bolas, bonecas e bichinhos espalhados... Só ficou faltando uma coisa... A D. Odete dizer se o bordado ficou bom ou não. Será que vai dar tempo de fazer o vestido para levar na viagem? Ah, viajar... Coisa boa... Ver coisas novas... Aprender... Quando fui a Araguari, fiquei muito curiosa pra saber o que era o tijolinho marrom com recheio branco que todo mundo andava mordendo pelas ruas com as melhores caras do mundo. Nunca tinha visto aquela casca seca e fininha de chocolate... Na caixinha amassada no chão, escrito... 'Eski-bom'. Sem palito... Como é que eu podia adivinhar que era um tipo novo de picolé? Demaais! Dessa vez vou conhecer Goiânia, nossa moderna capital e Formosa, cidade da vovó... Que novidades me esperam por lá?

No dia da viagem avó e neta vão cedo para a estação. O trem chega no horário. Sobem logo nele. Procuram os lugares no final do vagão. Do outro lado do corredor, viaja uma família. No banco, o pai, a mãe, um bebê de colo e dois meninos de pé, espiando pela janela. Eles se voltam para Luise entrando, cheios de risinhos, cochichos e cutucadinhas. Ela fecha a cara... Ara... Tomara esses meninos não... Desvia o olhar e percebe a bela toalha franjada sobre a qual os 
pais estão sentados... Nossa que capricho... Forrar o banco inteiro só pra não sujar as roupas! Não. Deve ser pro nenê... branquinha-branquinha... lambendo o chão desse jeito... Dá pena. Bleim! O sino anuncia a partida. "Vamos com Deus." Dona Mina se concentra em orações. Luise se distrai com o rebuliço das despedidas. Os de dentro botam a cara fora da janela, lançando olhares ansiosos... Os de fora levantam os braços na plataforma, acenando mãos e lenços... Dois apitos mais. O trem deixa a estação. Todo mundo se acomoda nos lugares... Menos... A menina cutuca a avó no ombro e cochicha... "Os meninos não têm lugar pra sentar. Será que vão viajar o tempo todo em pé?" Vó Mina põe o indicador em riste sobre os lábios e franze as sobrancelhas. O sinal faz a neta compreender que não deve falar sobre o assunto. A locomotiva uiva. Cospe fogo. Arrasta os vagões, sacolejando.

\author{
Café com pão \\ Café com pão. \\ Café com pão \\ Virgem Maria, que foi isto Maquinista? \\ Agora sim \\ Café com pão \\ Agora sim \\ Voa fumaça \\ Corre cerca \\ Ai seu foguista \\ Bota fogo \\ $\mathrm{Na}$ fornalha \\ Que eu preciso \\ Muita força \\ Muita força \\ Muita força ${ }^{6}$
}

Luise quieta no banco. De vez em quando enviesa o olhar para os meninos, brincando no corredor. Acha graça deles fingindo luta, quase sem fazer barulho. Não incomodam ninguém. Piuiiiiiii.. O trem vomita faíscas flamejantes. Morrem gris. As que entram pelas janelas, infernizam os passageiros... Invadem

\footnotetext{
${ }^{6}$ Primeiras estrofes de "Trem de Ferro", Estrela da Manhã, Libertinagem, de Manuel Bandeira.
} 
olhos. Chamuscam cabelos... Furam roupas. Noossa... Esse trem parece um bicho e dos grandes! Uma sucuri. Credo. A gente aqui, na barriga da sucuri. Engraçado... A gente fala sucuri... fazendo biquinho que nem a língua do... Merci. Ano que vem, a D. Ivete vai dar aula pra gente. Ela nem parece irmã da D. Odete. É bem diferente. Diz que a D. Ivete é mais braba. Cara disso, ela tem. Ensinando língua estrangeira então... Não deve ser fácil. Ainda bem que castigo lá no São Bernardino é só ficar em pé... Cara pra parede... Braços abertos, às vezes. Aquela professora... Esqueci o nome dela Costumava beliscar. Dar reguadas. Botar de joelhos. Bater... Bater mesmo... Só vi aquela vez, lá no Externato Santo Antônio. Irmã Maria Jacinta... Minha primeira professora no São Bernardino... Que paciência para explicar! Saudade. A D. Odete é educada, viajada... Mostrou pra gente, no mapa, o lugar de onde os pais vieram. Disse que já voltaram lá muitas vezes. Difícil entender certas coisas... a família Sultão viaja pelo mundo a hora que quiser... a D. Maria não poder voltar à terrinha dela nem uma vezinha só... esses meninos aqui, nessa viagem comprida... Luise vê os dois entretidos num joguinho qualquer. No chão, sentados de frente um para o outro, pernas abertas esticadas, botinas encostadas pelos solados fecham a área e evitam que as bolinhas de gude rolem pelo corredor. Precisa ser assim? Uns com... Slam! A porta de comunicação do vagão repentinamente aberta dá passagem à figura uniformizada, que entra e começa a gritar. "Bilhete! Bilhete!" O fiscal posta-se ao lado do primeiro banco e provoca movimentação geral. Luise vê as pessoas revirando bolsos, algibeiras, capangas... Cabeças de um lado para o outro. A menina conhece a rotina... Ele vai cambalear de um lado pro outro, passar de banco em banco, pegar a passagem de cada passageiro, colocar na boca aberta do jacarezinho, apertar a cabeça dele, fazer morder o cartão e devolver furado. Quando vou a Goiandira com a vovó, a gente fica na casa da D. Maria. Quintalzão enorme. Beleza de plantação. Nada melhor do que andar no meio dos tomateiros, podendo escolher à vontade, tirar os mais vermelhinhos do pé e comer ali mesmo... Huumm... Gosto bom! Augustinho é bom menino, sei disso. Gosto dele. Mas não quero saber da conversa fiada dos 'sem-que-fazê' com aquela bobojada toda... "pa-pa-pa...caixinha-de-fósforo...bla-bla-bla... Augustinho e Luise vão se casar..." Fico fula! Fecho a cara. Param os risinhos sem graça. Pronto. O Tulio... Tulio Veber. Gosto do nome. Desde o primeiro dia que 
apareceu lá na escola... As aulas já tinham começado, quando a família dele veio de outra cidade pra morar de vez. O Tulio é bonito... mas não é só boniteza, não... é o jeito dele... a educação... sei lá. Gosto do Augustinho. Gosto mesmo. De outro jeito. O Augustinho é amigo. Será que a gente não pode ter um amigo sem a tal falação... “...pa-pa-pa..coisa-e-tal..." Ah, neemm... Tem gente faladeira demaais! A D. Maria... Gosto dela... Tenho dó... Por causa daquele olho... Porque não pode viajar... Mas que é enredeira... ah, isso ela é. Ter a coragem de dizer pra vovó, na minha cara... "Cuidado, Comadre, tu estás criando cobra pra te picar." Bobona. Pensou o quê? Que a Vó ia parar de ajudar a filha... Largar os netos pra lá? Errou. Entrou num ouvido e saiu pelo outro. Quando a Mãe vai à "Terra Branca" dela, fica na casa da Madalena. As duas da mesma idade. Amigas de infância. Combinam. A Madalena é muito boazinha. Nem parece filha da D. Maria. É a do meio. O Augustinho, o caçula. O Guido, retratista, o mais velho. Esse... Olha pra mamãe de um jeito... Risinhos... Trejeitos... Acho que não se importa. Devolve tudo. Na casa da Madalena é bom ficar. Tem a Inês da minha idade, o Manuel mais novo, o Joaquim mais velho. Tantos gibis. Leio muito. Não tem um bom quintal... mas, na rua, tem as amendoleiras... Não. A-men-do-ei-ras. A Mãe já me corrigiu. "Bilhete." A menina vê o fiscal ziguezagueando pelo corredor e já passando do meio do carro. Por que a crescente inquietação? Não atina com o motivo. Do lado, a avó parece serena com os bilhetes na mão. Alguma coisa falta... Os meninos... Cadê? Desde quando deixou de ouvir o triscar das bolinhas? Começa a procurar. Onde se enfiaram? Ajoelha no banco. Volta a cabeça pra trás. Os pais, quietos... Parecem viajar só com o nenezinho. Desce. Olha de um lado e do outro. Onde foram parar? Lança um olhar aflito para a avó. De olhos semicerrados, parece não perceber. Não podia ser amolada com perguntas sobre os outros. Desassossego. Sobe de novo no banco. A cabeça vai e vem. Os olhos correm de um lado para o outro. Então vê dedinhos rechonchudos entreabrindo as franjas que lambem os pés do casal. Relampejo de olhos. No escurinho do cortinado. Duas carinhas sorridentes parcialmente expostas. A utilidade da bela toalha é entendida, num estalo. A apreensão é revelada com o alargar dos lagos no rosto. A mãe das crianças percebe. Faz cara feia. Ordena com um movimento de cabeça que se endireite para frente. Descendo do banco, Luise ainda vê a mulher baixar a 
mão livre e empurrar os dois volumes. Desaparecem de novo debaixo do banco. A rica brancura volta a cair naturalmente. Levando a crer que não passa de um cuidado a mais de gente bizarra. "Bilhete." A voz bem perto. Luise sentada muito direita. Apenas a cabeça pendida tocando levemente o ombro da avó. No peito, batidas aceleradas. No rostinho, a seriedade precoce. A expressão pode ser confundida com birra. Difícil imaginar o cérebro infantil arranhado por pensamentos que vagueiam e tangenciam questões que atormentam a humanidade. Desigualdade. Pobreza. Humilhação. Objetos das cismas da menina. Neste momento, diante do nariz dela, a presença dos botões dourados e do par de mãos alimentando um filhote com as passagens que custaram tanto à avó. Fecha os olhos. Acompanha mentalmente os gestos do homem, aqui e ali, verificando os dois últimos bilhetes apresentados pelo casal do lado. Slam! O estrondo esperado. Respira fundo. Sem graça. Cansada. Desanimada. Sensação de peso já conhecida. Ouve as vozes dos meninos, que se erguem, livres... Por enquanto. Recosta no ombro da avó. De olhos bem fechados. Queria dormir, sonhar, talvez. Por que não consegue?

Manhã avançada. A locomotiva alcança à estação. Todos desembarcam. Fim da viagem para alguns. Baldeação para outros. O trem que vai prosseguir não ainda chegou. Os passageiros esperam espalhados pela plataforma. Caminham. Conversam. Brincam. A avó e a mãe dos meninos trocam ideias. "A máquina tá muito atrasada." A neta borboleteia o olhar. Cadê os meninos? Ah, um tá ali perto do pai... O outro... Cloct-Cloct! Ahá... Pulando a linha, lá... De cá pra lá e de lá pra cá... Que nem a gente faz quando corta caminho pelos trilhos... Sonda a direção de onde vem o trem. Nem sinal. Cloct-Cloct! A gente pode escutar a locomotiva de longe. Tchiiiiiii... Ai, que susto! Tchiiiiiiii.. Que chiado é esse... Tchiiiiiii... O trem dando de fasto, sem apitar e nem nada... Que é isso... E o menino... Cadê? Agorinha mesmo tava ali pulando... Bem onde o trem... Santo Deus! Cadê ele? Gritaria. 'Hospital'. 'Depressa!' 
Confusão. 'O que aconteceu?' 'Não sei'. 'O trem pegou'. Correria. Na rua todo mundo apressado. Dona Mina carrega o nenê. Do lado a mãe é pranto e ladainha: “Ele não queria vim. Não queria viajá de jeito ninhum". "Ele não queria vim. Não queria viajá' de jeito ninhum" Luise tenta acompanhar os passos da avó, tropeçando agarrada na saia dela. Entram na sala branca. O pai já está lá, andando de um lado para o outro, o filho nos braços, qual oferenda. $\mathrm{O}$ olhar da menina se congela nas gotas grossas que escorrem para os cotovelos dele e vão pingando no ladrilho branco. Só consegue desprender os olhos da trilha de pétalas príncipenegro por força do murmúrio débil... "Água." "Água." "Água”. "Água." Ergue a vista, o fenômeno acontece. Como se mão piedosa desligasse uma lâmpada, o que mais ocorre ali é apagado. Escuridão na cabeça dela. Nem do resto da viagem, consegue recordar. Sabe que chegaram a Goiânia de noite. Lembra que ficou encantada com as lâmpadas redondinhas, alumiando a cidade.

Na pensão da dona Irene três dias, Luise absorve a rotina do lugar. Donos e hóspedes comem juntos no mesmo horário à volta da grande mesa retangular disposta no centro da sala. Come-se à vontade. Tudo é farto. Seja almoço ou jantar, é servida, primeiro a sopa perfumada, numa espécie de ritual. Todos acomodados nos lugares, a D. Irene destampa a sopeira, mexe e remexe, com a concha. No redemoinho do líquido espesso e fumegante os grãos de arroz abertos pelo cozimento são para a menina... Flores brancas pequeninas... Lirinhos de São José. Girando-girando... A mulher ergue a concha cheia. Parece dar uma ordem. Cada qual dá seu jeito de aproximar o prato. Agora, todo mundo tem seu laguinho de flores. "Falta o seu, Luise, chega o prato." A menina sorve a sopa devagar. Aqui, os hóspedes são muito comportados. Será que a D. Irene aprendeu com a D.Hermengarda? Era no livro do primeiro ou do segundo ano? A lição era engraçada. Na pensão da D. Hermengarda, quando um hóspede fazia qualquer coisa errada... Zaz! Aparecia na frente dele, um cartaz ensinando a fazer certo. Se alguém tomasse a sopa fazendo barulho... 
Zaz! 'Não faça ruído ao tomar a sopa'. Pro que mordesse o pão inteiro... Zaz! 'Parta o pão antes de comê-lo'. Pra aquele que falasse enquanto comia... Zaz! 'Não fale com a boca cheia'. Aqui, todo mundo com a cara pro prato. Pouco fala. Pouco ri. A D. Irene, sempre meio azedinha...

- Boa tarde a todos.

Luise vê quem entra e acompanha o coro na resposta... "Taaarde.” Bem que o Dr. José disse que costuma vir aqui, na hora do almoço, conversar. O rapaz entra perguntando:

—Como vai essa menina da cidade braba?

Luise sorri sem jeito, baixa a cabeça, o rapaz senta e entabula conversa.

O consultório é do lado. Fácil tirar um tempinho. Deve trazer novidades. Assuntos inteligentes. Decerto.

-O jogo de ontem, escutaram?

-Ara... Empate.

—É... Mas foi um jogo raçudo!

- Melhor fez o Corinthians em São Paulo.

— No Rio de Janeiro, o Flamengo também botou pra quebrar.

A menina observa que a maioria dos presentes... mostra interesse e participa. 
- Por falar na Capital... li uma notícia e lembrei da senhora, D. Irene. Chegou ao Rio de Janeiro a banha americana que vai ser vendida a $\operatorname{Cr} \$ 18,00$ o quilo.

—É mesmo!?

Luise vê o espanto da mulher colocando o riso em quase todas as caras à mesa. Sempre educado. Dá atenção.

— Por lá, a coisa anda feia...

A menina não perde o fio da conversa conduzida pelo dentista. É toda admiração... Tão novo e já dentista formado...

- O Lacerda com aquela língua afiada... Diz que outro dia no plenário do Palácio Tiradentes berrava ao microfone, quando alguém gritou: "Vossa Excelência é um ladrão da honra alheia!" Não titubeou e respondeu, na lata: "Então... Vossa Excelência pode ficar tranquilo pois não tem nada que eu possa lhe roubar."

Alguns segundos se passam até a gargalhada se sobrepor ao tilintar dos talheres.

Ha-ha-ha... "Li no jornal." "O jovem Villas-Boas Corrêa escreveu. Ha-haha... Ele é bom mesmo."

\section{É bonito. Quando crescer, quero conhecer alguém...}

- Parece que dessa vez, o Presidente tá mesmo "estrepado". A poderosa concentração local da oposição civil e da força militar pedem a sua saída, abertamente. Mesmo eleito democraticamente os adversários mais radicais não se conformam com o retorno dele ao cenário político.

- Vem governando quase acuado depois daquele atentado desastroso contra o Lacerda, na Rua Tonelero, em Copacabana, no ano passado.

- Sinais de crime político... Cheiro de possível envolvimento da Guarda pessoal do Presidente... O próprio governo em questão... Na Tribuna da Imprensa, o deputado udenista alvejado com um tiro no pé diz que Getúlio não é mais o chefe legítimo do governo. 
— Dr José... O Sr. acha que essa banha vai chegar aqui?

- Com o tempo acaba chegando sim, D. Irene.

— Hum! Pois sim... Eu é que não vou abrir mão de picar e fritar o meu toucinho.

As pessoas em volta se divertem com o comentário enfático da mulher.

- Momento terrível. O presidente quase só. A única saída pra ele agora é deslanchar a sucessão... Juscelino vai ser candidato... tá bem forte, lá em Minas...

— Ô, ô... Tem que fazer isso com jeito pra não melindrar o Aranha. Costuram o acordo UDN-PTB em torno dele, já apalavrado com a UDN.

- Por que Vargas daria apoio a Juscelino? Os valores dos dois não são os mesmos.

— Não são inteiramente compatíveis... Mas o mineiro é homem de ação e se identifica com o gaúcho no compromisso democrático, ambos convictos da necessidade do desenvolvimento econômico e da integração nacional.

- Mesmo na incerteza de ser indicado Juscelino faz pré-campanha. Veio conversar com o Ludovico em novembro do ano passado... Voltou esse ano em janeiro...

- O nosso governador é entusiasta da transferência da capital...

- O potencial eleitoral de Juscelino é fortíssimo. O trunfo deixa Vargas impressionado. Apesar dessa crise, o apoio dele rechaçaria a ameaça de outras lideranças políticas.

- Sem aliança e sem apoio... Se o presidente não tocar a sucessão agora... A vaca vai descambar no brejo... Duvida, Coronel?

Desta vez, a pergunta tem endereço certo. Luise percebe o mutismo que se estabelece, depois dela... Ué! Segue os olhares e vê... todos na direção do Carafeia... Por quê? O velho continua a comer, cabisbaixo. O silêncio incomoda e começa a ser quebrado: uma cadeira range... pés arrastam... alguém limpa a garganta... D. Irene parece ter deixado alguma coisa cair debaixo da mesa, procura e não encontra... Vó Mina levanta e vai para a cozinha... Com a gente aqui, meio de favor, vovó fica ocupada demais. De repente, a voz roufenha vem lá do prato do único hóspede que até então não dissera nada. "Ele 
vai aguentar." Suspiros de alívio. Tensão quebrada. O dentista manda logo outra pergunta.

A menina observa as pessoas. Um coça o nariz. Outro cofia a barba. O murmúrio rouco ouvido logo de novo põe fim às expectativas de outra pausa longa e embaraçosa... Ele é o mais calado e o mais triste daqui.

- Tem garra. Vai segurar. Faz isso desde que chegou lá e botou limite naquela discricionariedade desmedida.

\section{Dis-cri-ci-o- na-ri-e-da-de... Palavrona boa para brincar de forca.}

— Dissolvendo o Congresso...

O jovem age como o pescador, dá linha ao peixe e não deixa escapar.

- Tinha que botar freio nos excessos. A política dos Governadores... Bagunça.

— Nomeando interventores...

Contra-resposta rápida. Tom alterado.

— Água na fervura! Estratégia de estadista! A costura de acordos com os Estados evitou derramamento de sangue.

Pela primeira vez, Luise vê o Cara-feia falando de cabeça erguida e dela não passa despercebido o lirinho de São José, expulso pelo tremor do bigode, sumindo de novo no encardido da camisa.

- Convenhamos coronel, os paulistas só queriam forçar a reconstitucionalização.

Re-cons-ti-tu-ci-o-na-li... Luise interrompe a contagem das sílabas porque vê o ancião cada vez mais vermelho, vociferando e gesticulando, com garfo espetado no ar.

- Ah... Não me venha com a mesma desculpa dos separatistas. 
- Oportunista. Outorgar aquela constituição centralizadora com a desculpa de que seria aprovada num plebiscito que não veio, só pra prorrogar o próprio mandato.

Com efeito, o Doutor José devia parar de cutucar o outro desse jeito. O pinga-fogo verbal entre o jovem dentista e o velho coronel ganha força, ao invés. Não vê que tá abusando? D. Irene tá levantando com cara de quem não aguenta mais... $\mathrm{O}$ marido, aonde vai?

- Repito as palavras que o nobre estadista dirigiu à nação, naquele momento difícil... "A crescente agravação dos dissídios partidários leva a resolver-se em termos de violência colocando a nação sob funesta contingência da guerra civiiil..."

O Coronel engasga, tosse e continua. Que coisa...

— Você é muito verde rapaz. Só sabe a história pela "tioria". Se tivesse visto o que vi naquela época... mistureba de ideias... revolta de comunistas... insuflação popular... e o conflito externo pra piorar. Só um irresponsável entregaria o país daquele jeito.

\section{O Cara-feia tem discurso pronto na ponta da língua!}

- Quando a guerra acabou, a insatisfação interna voltou e mostrou a necessidade de convocar eleição... Daquela vez, o povo não quis esperar pra ver se o pleito ia acontecer ou não e deu logo o contragolpe, fazendo o homem provar da própria gororoba.

Que lenga-lenga mais enjoada! Podia bem ajudar a vovó na cozinha... Não fosse a D. Irene me olhar enviesado, daquele jeito, quando entro lá e começo a mexer em qualquer coisa... Como se tivesse estorvando... Sei lá... fico sem graça e acabo saindo. Deve pensar que não sei fazer nada direito. Deixou a calcinha dela de molho, viu que tentei tirar aquelas manchas amareladas de todo jeito. Ela não pediu. Mas eu queria ajudar. Esfreguei. Esfreguei. Tenho culpa se não saíram? Lá fora agora tá muito quente... 
- E o que veio depois?

- A chefia do governo foi passada ao Judiciário, o único poder a subsistir na barafunda.

— Não, meu filho, eu estou perguntando de-po-is... Passados os cinco anos, na primeira oportunidade que teve... O povo pediu o quê?

O Cara-feia rindo? Luise duvida. Com razão. A máscara que assoma ao velho rosto não expressa o riso, mas estampa a ironia que a inexperiência da menina não permite discernir. O coronel começa a cantar... "Bota o retrato do velho outra vez". A menina fica confusa... Ah, neeem... Toda essa discussão e parece que ele ganha mais vida! " Bota no mesmo lugar."

- Os queremistas. Mas agora os tempos são outros, Coronel, tem o Lacerda...

\section{Chega! Ficar enfurnada no quarto ainda é melhor do que aqui,} escutando essa chatice. Luise levanta com a intenção de dar uma palavrinha antes com a avó. "Tenho medo de que ainda deixe um cadáver na minha mesa." Escuta vozes baixas no corredor. Não pode chegar à cozinha e nem passar para o quarto sem ser vista. Para. "Ora, não se preocupe minha flor, ele sabe o que faz." “Ah, sabe, sei... Não devia fazer isso... Pode ser perigoso... Tu viste como o velho ficou hoje?" "Não vê que fez de propósito?" A menina escuta curiosa... "Com a importância e o prestígio que teve... Relegado desse jeito é quase como se estivesse morto". Estão falando do Cara-feia! "Viu o entusiasmo tomando conta do pobre diabo? O dentista soprou a camada de cinza, expôs a brasa viva e ardente. O Dr. José sabe lidar com velhas raposas. Não é caso de ideologia. "Ah, tu sabe que eu não entendo essas coisas." "Nem precisa... Basta saber que a oposição aqui começou com desentendimentos entre as famílias que dominavam, lembrar que o Dr. José nasceu no seio de uma delas e entende de política como ninguém. Então, era isso... Um jeito diferente de ajudar. "O dentista sabe o que faz." "Tomara esteja certo." "Está se preocupando à-toa... Vem cá, Bem..." Luise aproveita a chance para escapar dali, pé ante pé. 
Sem essa boneca esquecida aqui, eu ia brincar de quê? Só se fosse com aquele bolinho de cabelo, rolando no chão... "Ei, bonequinha! Sua dona largou você pra traz... Nada de choro. Não é mais uma menina. É uma mocinha... Como eu. Luise cata o emaranhado de cabelo do assoalho e ajeita entre as pernas da boneca. Olha só... Começa a ter cabelinhos... Daqui a pouco, peitinhos. Cabelos nascem sem doer, mas peitos... Ai-ai... Qualquer esbarrãozinho... iiiff... Sua doninha deixou você aqui sem querer. Decerto. Esqueceu. Tadinha. Deve ter ficado triste. Sentido falta. Sei disso. Também já tive uma bonequinha linda... Quase quê...” A imaginação da menina organiza as imagens que a lembrança dela oferta, e as quatro paredes do quarto desaparecem para dar lugar a certa tarde luminosa, recomposta. A aula acaba mais cedo, Luise desce a escadaria do São Bernardino e vê o céu... Bacia de porcelana azul virada pra baixo e uma gema de ovo escorrendo dentro... Devagarzinho... Do outro lado da rua, o frutificado pé de amora. Atravessa com a criançada. "Pretinha, pretinha, já não tem." Mãozinhas ligeiras, no futricar. "Cataram todas." Galhos flexíveis puxados e repuxados. "Vermelha é azeda." "Verde é amarga." "Argh.” "Não dá pra comer." A desistência. A amoreira tonta a se recompor. A meninada na direção da ponte. Luise junto. Variando o caminho. Alcançam a avenida. Atravessam. O jardim tremelicando sem compostura. $\mathrm{O}$ vento fazendo cócega na buganvília... Na velha árvore que parece ser eucalipto, mas não é. As onze-horas bonitas demaaais. Branca... Rosa... De qual gosto mais? Ah, eu gosto mesmo é de todas! No ar, aroma exótico. Síntese dos cheiros. A menina para trás. Olha para o banco. Vontade de ficar. Precisa ir. Atravessa a rua em frente à igreja evangélica. Dobra à direita na esquina do Dr. Lamartine. O largo fecha em rua. Sol escondido atrás das casas. Sombras espichadas. Caminha. Desemboca no largo da matriz. $\mathrm{O}$ astro a descoberto brilha outra vez. Na lateral do templo, do outro lado da rua, a casa comercial convida a espiar novidades. 'Primeiro a obrigação, depois a diversão'. Ela entra na igreja. Faz breve oração. Sai. Atravessa. Para na porta da loja... Ah! Não pode acreditar. Fecha os olhos. Abre de novo. Não era sonho. Era uma maravilha! Estava lá. Em pezinha. No meio da miscelânea. A boneca mais bonita do mundo! De porcelana. Cabelo louro. 
Olhos azuis. Boca cor-de-rosa. Vestido cheio de rendinha. Daquele dia em diante, só volta para casa depois de passar pela igreja, rezar, atravessar e ver a boneca. Pedir não adiantava. Nem contar para ninguém. Guardou segredo. O Natal perto. Valia tentar. Rezou. Esperou. Boneca, nenhuma?! "Eu e o Esteves achamos que já está grande e vestido é melhor." Corte de fazenda até Bonitinho... Fundo branco... Florzinhas azuis jogadinhas... A boneca sumiu. Ganhou nova dona. Decerto. A lembrança guardou. Belas tardes. Cara colada na vitrine. Fantasiando... A bonequinha era minha. As quatro paredes do quarto voltam ao lugar. Eu tinha só nove anos. Agora tenho onze. Sou mesmo uma mocinha. Não ligo mais. Atira o chumaço de cabelo longe. "Sabe de uma coisa, bonequinha... Quando eu voltar da viagem, vou pegar a Gillette da Mãe raspar pernas e tirar fora os pelos... Senão... Já pensou? 'Uma moçona dessas, que já tem até cabelo na pere...' "Quer saber... Vou lá fora um pouquinho e você vai dormir". Acomoda a boneca no travesseiro e deixa o quarto.

\footnotetext{
Ordem!

Seu lugar!

Sem rir!

Sem falar!

Num pé!

No outro!

Numa só mão!

Na outra!

Bate palmas!

Piruetas!

De trás pra frente!

Meia volta...

Volver! $^{7}$
}

Luise passa pela sala. Ninguém mais. Pega o limão encostado ao pé da mesa. Sai pela porta. Desce a escadaria. Começa a jogar a fruta na parede. “Ordem”. "Seu lugar". "Sem rir”. "Sem falar..." Na porta do consultório, o Dr.

\footnotetext{
${ }^{7}$ Jogo infantil.
} 
José se despede da paciente e observa a menina. Graça. Habilidade. Ordenando e obedecendo ao próprio comando. "Num pé." Com um pé no ar, agarra o limão, joga outra vez e se equilibra... "No outro." Pega a fruta, joga, estende a palma e segura... "Numa só mão.” Joga e recebe. "Na outra.” Arremessa. "Bate palmas." Pega. Lança. Gira os antebraços um em volta do outro. "Piruetas." Apara. Vira o corpo para trás e atira. "De trás pra frente." Faz a "Meia volta...Volver!” Pega a fruta com as mãos em concha. Recomeça. "Ordem." Brincadeira comum entre as crianças. Dizeres peculiares. Quem teria inventado o jogo? Um militar enaltecendo a disciplina? Um civil espirituoso? Um artista parodiando o formalismo? O dentista suspira. Entra. Talvez pense nele mesmo, menino, jogando bola na parede lateral do casarão do interior. "Parece que foi ontem." "Doce pássaro da juventude." "Ligeireza." Mais tarde, ao sair vê o limão esborrachado.

Depois do jantar, a menina sai da mesa e vai sentar no último degrau da escadaria. A noite engolindo o dia. Lenta. Quente. As impressões chegando... Aiai... Quase uma semana e só conheço essa rua. Goiânia não é só isso. Queria ter ido à Praça Cívica... Ao Palácio das Esmeraldas... Ver a estátua do Bandeirante... A casa da D. Irene é bonita... Chão forrado de tábuas... Essa escada... Mas, nenhum quintalzinho. A porta da cozinha abre pra área de cimento. Aqui fora, não tem árvore. De tarde, bate sol de estalar mamona... Se tivesse mamoneira. Claro. Na minha cidade, tempo de férias brincadeira da criançada na porta de casa até tarde... Pique-esconde. Cabra-cega. Carimbada. Orticã. Roda... "Roda das flores tem flor de toda cor..." Tem mesmo... As duas irmãs polonesas, o Ybrahim turquinho, o Takinho japonês, o João Preto, o Elcio louro, o Ruiz carinha de índio, a Helena branca, a Marizé moreninha,... Aqui... Sem criança... Sem flor... Sem árvore... Essa rua não tem nada. Ainda bem que... 
- Boa noite D. Luise.

-Ai, que susto! Boa noite.

—Então é amanhã que a senhora está indo para Arraial dos Couros?

— Dona... Senhora... Ara, Dr. José! A gente tá indo mesmo é pra Formosa, terra da vovó... Lembra?

— Então não sabe que Arraial dos Couros foi o primeiro nome da cidade da sua avó?

- Arraial dos Couros?

- Sabe por quê?

— Por quêê?

- Por causa da malária, Luise, por causa da maldita.

- Credo!

— É verdade. A doença começou a se alastrar no Arraial de Santo Antônio e o povo a fugir de lá apavorado pra acampar fora da cidade. Os comerciantes que vinham de Minas Gerais e da Bahia amedrontados a arranchar no meio do mato, armando as barracas de couro entre as mercadorias que traziam. Com isso, o lugar ficou logo conhecido como Arraial dos Couros.

— Nossa! Não sei se a vovó sabe disso... Ela me contou do Anhanguera...

- O que foi que ela disse sobre o Anhanguera?

Luise reconta o que ouvira da avó.

— E na escola aprendi que ele é o fundador da Cidade de Goiás.

- Sempre fazem baita confusão aí, menina.

O dentista encosta o corpo na parede e apoia o pé no degrau inferior da escada.

- Quem fundou a antiga capital do nosso Estado foi o Bartolomeu Bueno da Silva Filho e a primeira vez que pôs os pés aqui tinha doze anos.

- Doze? Eu tenho onze.

- Pois é... O meninote, com pouco mais idade que você, veio na companhia do pai, o "Anhanguera", Diabo Velho, que ganhou o apelido dos 
índios, incendiando aguardente na frente deles e ameaçando queimar as águas dos rios, para que contassem onde estava o ouro.

- Bruto!

— Pois é... Na época, surgiu a lenda da Mina dos Martírios...

— Mina dos Martírios... Nunca ouvi falar.

— Já fez Primeira Comunhão?

- Jáá...

— Lembra os símbolos da crucificação de Cristo?

- A coroa de espinhos, a lança e os três cravos.

- Muito bem. Bartolomeu Bueno da silva saiu de São Paulo trazendo o filho, na intenção de prear e escravizar os "Guayazes". Chegou às aldeias “Araez" e "Goyaz."

A menina do presente ouve a história do menino do passado, olhos arregalados, quase sem piscar. "No caminho, o pai apontou uma pedra alta, à distância e disse que via os símbolos da crucificação, gravados nela. Acreditou que fosse um sinal. Chamou de Mina dos Martírios. A missão terminou, o pequeno Bartolomeu voltou pra São Paulo, levando a semente de um sonho: voltar um dia e buscar o ouro dos Martírios.” Na cabeça da menina, imagens do tempo atrás materializadas nas palavras do dentista. Ela via o menino exultante diante de uma serra de ouro... Olhos faiscando... Sorriso alargado...

"O tempo passou. As águas correram no Tietê. O menino se fez homem. Quarenta anos depois de ter ouvido o pai falar sobre os Martírios, Bartolomeu Bueno da Silva Filho, que acabou adotando o apelido do pai, Anhanguera, saiu de São Paulo chefiando a própria bandeira, desceu pra Goiás, cortando vales, atravessando o Paranaíba e..."

- Ah, esse pedaço, eu já sei. Achou o pouso do Córrego do Almoço e quando foi embora, deixou o espanhol Catalão.

- Ha-ha-ha... Pode ser que esteja certa... O Bueno andou destacando grupos para vasculhar a região conhecida hoje como Rio Verde, Rio Claro e Rio Bonito.

— Um monte de "bandeirinhas" espalhadas pelo sertão? 
- Mais ou menos isso... Ha-ha-ha... A "bandeirinha" do genro dele, João Leite, membro principal da expedição achou ouro no Rio dos Pilões. Outra colheu amostras no Rio Claro. Mas o 'diabo novo' insistia em encontrar a Serra dos Martírios. O tempo passando. O cansaço aumentando. O desânimo tomando conta da tropa. Ele não desistia. Calava as reclamações. "É descobrir o que se busca ou morrer na empresa." Disciplina firme.

- Como o Sr. sabe disso?

- Documento histórico... Quer dizer... Tá escrito numa carta que Rodrigues César de Meneses, governador de São Paulo, mandou pro rei.

$-\mathrm{Ah}$.

— Depois de três anos que saiu de São Paulo, Bartolomeu Bueno da Silva Filho chegou ao Rio Vermelho e achou ouro para valer.

— Encontrou a Mina dos Martírios?

O dentista troca de perna e muda a posição na parede.

- Aí é que tá, menina especula, na época ele garantiu ao irmão, Simão, que reconhecia o lugar da pedra alta onde o pai dissera ter visto esculpidos os símbolos dos martírios. Com a expedição encontrando ouro em cinco ribeiros, número igual ao das chagas de Cristo, deu por cumprida a missão e voltou pra São Paulo pra receber honras. Nomeado Capitão-Mor Regente das minas de Goiás, ganhou terras de sesmaria e o direito de cobrar pela passagem das canoas nos rios do percurso. A notícia do ouro criou interesse enorme. Outra bandeira foi logo aprontada. Então, fundaram os arraiais. O bandeirante fez sua moradia à beira do Rio Vermelho. Autoridades construíram residências ao redor. A província importante virou Vila Boa de Goiás, com o Boa de Bueno. Ao receber o título de cidade, passou a Cidade de Goiás.

— Ué... Não devia ser Cidade Boa pra continuar lembrando o Bueno? 
De noite, deitada ao lado da avó, a menina custa a dormir, contando os novos conhecimentos.

- O pior, foi ele perder tudo.

- Como assim?

- O Bartolomeu não soube zelar pelas riquezas dele.

- Hum...

— Largou o negócio da cobrança da passagem das canoas na mão do filho e...

— Desaguou. 'Gado só engorda debaixo da vista do dono.'

- O governador de São Paulo soube que o bandeirante estava passando dificuldade e adiantou uma arroba do Tesouro Real pra ele.

-Uma arroba... O homem ficou rico de novo.

- Antes tivesse. Deu tudo errado. Quando o rei ficou sabendo não quis confirmar a dação... Não... Do-a-ção, como o Dr. José falou.

- O governador tinha colocado o carro na frente dos bois e o bandeirante teve que voltar o adiantamento.

- Pior. Teve que leiloar o que tinha... Casa... Escravos... Até as joias da mulher. Tudo arrematado do mesmo jeito que as prendas da quermesse de Santo Antonio: o bolo da dona Marli... O frango-cheio da dona Olga...

- Triste exemplo de descontrole...

- E tem mais. Diz que, uma vez, um general cruzou o Rio Corumbá perto do Arraial de Santa Cruz e conheceu os bisnetos do Anhanguera. O Dr. José falou que o soldado ficou pasmo de ver a miséria das duas moças e do rapaz de dezessete anos, vivendo num casebre muito mal mobiliado.

- Acabar desse jeito... Será verdade?

- O Dr. José explicou que os militares relatam tudo o que acontece, quando viajam e o general falou até da tristeza que sentiu, vendo as moças passando necessidade, e o 'príncipe da nobreza goiana' vivendo de trabalho braçal.

- Ara... O trabalho não mata ninguém. 
Por um instante, Luise pensou no marido dela imprensado pelo tronco de anjico...

- Pensa bem, Vó... Sendo bisnetos do Bartolomeu Bueno da Silva, o Anhanguera e netos do Bartolomeu Bueno Filho, o desbravador da nossa terra... Precisavam passar por aquilo?

— Desbravador para uns, "bravador" para os índios... Tiveram triste sina.

- Diz que dois anos mais tarde, o mesmo soldado passou por lá e viu que o governador dera pra família Bueno a renda do pedágio do Posto de Corumbá, que um dia já tinha sido do pai deles.

- Sabe filha... Ajudando aquela gente, o governador ajudou a si mesmo.

— Como assim?

- Evitando falatório, mexerico de viajante reparador de tudo.

- Falando em fuxico... Em todo lugar que a gente chega é sempre a mesma coisa: "Você é de Catalão? Aquela cidade de gente braba, ruim?" Já reparou isso, Vó?

- A fama vem de histórias de antigamente...

- O pior é que falam isso de um jeito! Como se todo mundo lá fosse... Rude... Grosseiro... E nem adianta tentar dizer que isso não é verdade... Acabo sem saber o que falar.

— Melhor é largar isso pra lá. Agora vamos dormir.

Viagem de jardineira. ${ }^{8}$ Saída cedo. Luise animada. As horas passam. O calor aumenta. Que estradão! Que poeira! O trem fazia lembrar uma sucuri... Essa jardineira parece uma tartaruga. Grande. Molenga. Desengonçada. Casco de madeira e lata. Narigão na frente, fuçando o caminho espichado e lá vai... Passando na buraqueira... Sacolejando a gente pra lá e pra cá... Fazendo todo mundo cabecear. Pinóquio deve ter enjoado na barriga da

\footnotetext{
${ }^{8}$ Coletivo utilizado em zonas rurais para trajetos de média a longa distância, resistente as típicas estradas de terra.
} 
baleia. Maior que vaca. Vi no filme. Corcoveia. Dá pinotes. Mergulha de cabeça. Levanta o rabo. Espirra água... Fluuussshhh... Aqui, é o motor... Rooommm... O trem demora. Mas, a gente não sente tanta canseira. Ehê viajona! De repente, a boca enche d'água... Gosto de bicarbonato... O enjoo avoluma... A menina põe logo a cabeça fora da janela... O lanço não demora a subir. Azedo. Ardido. O vento leva...

- Melhorou filha?

— Não muito... Vó, como era antes fazer uma viagem comprida dessas?

- De primeiro, carroças, cavalos... Era difícil... Podia demorar muito... Depois, vieram as jardineiras... Não tinham previsão confiável de saída ou chegada. Quebravam na estrada. Atolavam na lama.

— Tomara um dia façam estradas de ferro pra todo lado.

- Pode acontecer.

- Acha mesmo?

- Já tiveram a ideia de ligar sul e norte de Goiás levando a ferrovia até Palmas e à beira do Rio Tocantins. Pensaram também numa comunicação do sul com o oeste, com um ramal passando por Araxá, Uberaba e seguindo pro Rio Paraná.

— Já pensou, Vó, poder viajar pelo Brasil inteiro de trem... Que maravilha! A avó vai espichando o assunto e distraindo a neta.

- Pensaram em fazer os trilhos da Oeste de Minas que paravam em Formiga e a linha da Mogiana que acabava em Araguari passar por Catalão. A construção saiu de Formiga, chegou a Porto Real, construíram uma ponte de viga metálica pra atravessar o Rio São Francisco. Os trilhos chegaram à Serra do Urubu e tiveram que picar a rocha bruta pra abrir um túnel... empregando mais de 1200 homens.

— Noossa... Gente demais!

- Mudaram os planos.

— Por quê?

— Política... Dinheiro... Interesse... Essas coisas... A construção dessas estradas traz muita complicação. A gente ouvia falar de atrasos estranhos... terras interditadas... 
— Vó... Tô ficando enjoada de novo... Acho que vou...

— Põe a cabeça na janela... Respira fundo... O vento vai ajudar a melhorar.

- Pode continuar. Tô escutando daqui.

- Bem... Com a mudança, a linha devia sair de Araguari pra Goiás Velho e de lá um ramal pro Rio Tocantins com um prolongamento pro Rio Araguaia e uma ligação pelos dois rios levando ao norte do país.

- E Catalão?

- O ramal saiu de Araguari pra Catalão sofreu mudança de quinze quilômetros no traçado. Acabou indo pra Goiandira. A imposição de aproveitar um nivelamento disfarçou o obstáculo da serra. Quando os trilhos chegaram a Amanhece a inclinação do terreno mostrou a necessidade de cortes de trinta metros na rocha e de aterros enormes no Morro da Mesa. Foi aí que aconteceu o acidente... Uma gôndola de trilhos desprendeu da composição, desceu voando e bateu direto na do engenheiro com o ajudante.

- Iiifff...

— Engenheiro Bethout é o nome da estação homenageando ele. Chegando a divisa de Minas e Goiás...

- Já sei... Precisaram construir uma ponte metálica pra atravessar o Paranaíba.

- Precisaram. Mas a ponte não embaraçou em nada, porque enquanto era construída desmontaram a segunda locomotiva e continuaram pra Cumari. Os trilhos já tinham atravessado o rio e avançado com várias estações pra chegar a Roncador. Aí, as obras foram paralisadas e só recomeçaram uns oito anos depois, avançando até Leopoldo Bulhões.

- Acho que o enjoo passou...

- A carinha tá melhor... Vem... Deita aqui no meu colo e fica quietinha. Deve faltar pouco pra chegar à parada.

- Depois de Leopoldo Bulhões, a ferrovia seguiu pra cidade de Goiás, deixando Catalão de fora?

- Vieram mais complicações. Os endinheirados se uniram e compraram terras onde devia ficar a estação aprovada no mapa. O diretor passou pelo local de automotriz. Perguntou que loteamento era aquele. Soube do planejamento de explorar venda de lotes virou bicho: "Esses capitalistas não têm medidas" Não 
quis se submeter à política araguarina, forçando pra manter a vantagem de estação última...

— Que vantagem, Vó?

— Serviço de carregamento... Vendas... Comissões...

$-\mathrm{Ah} . .$.

$\mathrm{O}$ diretor tocou o prolongamento pra Vianópolis. Acabou afastado e substituído. Nesse meio tempo, Goiânia ganhou a preferência de ponto final da E.F.G. O ramal tomou a direção da futura capital. Chegou a Anápolis, a 430 quilômetros de Araguari, em 1935.

— Puxa, Vó... Como lembra tudo isso... Até a data?

— Ah, minha filha... Morando em Goiandira... Caminho da construção... A gente não tinha como deixar de acompanhar aquilo tudo... $\mathrm{O}$ ano foi fácil guardar porque é o mesmo da mudança da nova capital do Estado. Anápolis não ia abrir mão fácil da vantagem de estação final e a gente já sabia. Com a chegada da ferrovia, passou a ser o maior comprador de ferraduras do Estado por causa do comércio de cargas na região. Pelas estradas carreira e cavaleira tropas, carroças, cavalos no leva e traz dos produtos pra troca na estação ferroviária da cidade. Vieram mais disputas... Mais brigas... Mais problemas de traçado... Mais desperdício de tempo e dinheiro... Até Goiânia ser alcançada pelo trem, em 1950. Lembra como é bonita a estação de lá?

— Só das lâmpadas redondinhas... Era de noite... Não vi direito...

—É uma construção diferente, moderna...

— E Catalão... Como ficou nessa história?

— Em Catalão, a estação foi inaugurada, num sete de setembro... Três anos depois da inauguração da de Goiandira. E a Oeste de Minas passou pro Estado de Minas Gerais, com o nome Rede Mineira de Viação...

- Ah... A famosa RMV... Os meninos chamam de "Reforma Mulher Velha."

- Ah, é...

A neta vai acompanhando o pensamento da avó esticando a conversa. "Hoje, uma pessoa pode sair do Rio de Janeiro pra São Paulo, pegar o trem da 
Mogiana, viajar pro Triângulo Mineiro, trocar pro da E.F.G. em Araguari, entrar no Estado de Goiás por Goiandira e seguir até Goiânia. Ou pegar RMV em Minas Gerais, passar por Catalão e chegar a Goiandira... O Brasil é muito grande, viajamos esse tempão e nem saímos de Goiás.O trem aqui é importante também pra escoar grãos, sebo, charque... “"

De vez em quando, Vó Mina é interrompida... Náusea... Vômito... Cheiro azedo... A estrada parece que não vai terminar nunca...Não dá pra conversar direito. Não dá pra dormir. Não dá pra comer. Nem da matula que a vovó trouxe. Nem nada das paradas. Enjoa ainda mais ver o povo cabeceando... Quase todo mundo vestido de guarda-pó... Comprido... Que nem avental de médico.

A jardineira vai roncando preguiçosa e chega a hora da menina ouvir... “Cristalina!” ...e o esperado... "Chegamos.” Ufa! Distância tem fim. Pensão limpa. Banho quente. Comida fresca. Cama macia. Sono de pedra.

Dia seguinte. Mais jardineira. Mais sacolejo. Mais poeira. Não sei o que pode ser pior... A jardineira quebrar na estrada no tempo da seca... Ou atolar na lama no tempo das águas... Tomara não chova. Esse muro de poeira levantada... A quentura... O cheiro forte... Ainda é melhor do ficar parado à beira da estrada... Já pensou? Ainda bem que viajamos um bom pedaço de trem.

- Vó... Quando o meu pai veio do Maranhão pra Goiás, os trilhos avançavam pra on...?

- A notícia da construção da estação provocou uma corrida desenfreada, gente chegando diariamente pra esperar o começo das obras...

- Nossa... Foi tanto assim? 
- A estrada de Ferro trouxe muita gente pra Goiás. A guerra também. Vinham italianos, japoneses, alemães... Catalão sempre recebeu pessoas de fora, como os sírios-libaneses, entrelaçados nas famílias catalanas... Sebba, Fayad, Abrão, Safatle, Salles, Aziz, Simão...

- O meu padrinho, a minha madrinha...

- Pois é... em Catalão, eles não são só comerciantes, são fazendeiros, industriais... Há os que estudam fora, viram médicos, advogados, dentistas e voltam pra trabalhar na cidade, usando a inteligência, pro bem do povo... O Dr. Jamil..

- É mesmo, Vó... O meu padrinho Miguel... As professoras Odete e Ivete... O professor Chaud...

- Sabia que foi ele que criou o Ginásio?

- É mesmo, Vó?

— Chamava "Presidente..." não sei o quê... Um nome estrangeiro... Depois foi comprado pelos padres franciscanos, virou o Ginásio são Bernardino de Siena, com a sua Escola Paroquial comandada pelas freiras franciscanas.

- O professor Chaud é muito inteligente mesmo.

— Pois então... é certo que participam de todos os negócios. Ativamente. A comida deles já faz parte da nossa alimentação... O quibe...

— Ah, Vó, a madrinha faz um quibe... Huum! Aprendi. É trabalhoso. Ela põe o trigo de molho um tempinho, espreme, passa três vezes pela máquina de moer, com um pouco de sal, pimenta do reino, bastante cebola e hortelã. Depois mistura a carne e mói mais três vezes. Para fritar, molda o quibe em volta do dedo pra fazer aquele furinho no meio e rechear com o refogadinho de carne moída com cebola... À vezes faz o quibe chato, redondo, como bolacha. Quando quer assar, coloca um pouco de manteiga e espalha a massa no tabuleiro. Quero aprender como faz aquele arroz com macarrão tostado...

- Pois é... O catalano pode comer um dia quibe, arroz de lentilha, tabule, charutinho de folhas, mahfuf, abobrinha recheada... e o outro, galinhada, gueiroba, churrasco carne frita, arroz com suã, arroz com pequi...

- Ah, Vó, nem fala... Se tivesse agora um arrozinho de pequi... Pepita de ouro do cerrado!

— Ha-ha... Não deixa de ser. 
Luise logo vê que a viagem de Cristalina a Formosa é mais curta do que imaginava e sai satisfeita da jardineira.

$\mathrm{Na}$ casa antiga, rente à rua, a parenta viúva casou a filha e mora sozinha. Avó e neta no conforto do quarto espaçoso. Janelão aberto. Sol matinal generoso. Do resto da casa, a cozinha se destaca. Desemboca na varanda interna prolongada pelo caramanchão de maracujá. A ramagem desgarrou das grimpas da jabuticabeira e alcançou o telhado, formando aprazível cobertura verde, florida, frutada. De lá, o olhar de Luise abarca a mistura de cores. Mangueira, laranjeira, cajueiro, goiabeira, bananeira, mamoeiro... Aquarela. Mais embaixo pendendo do galho do pé de manga-de-outra-qualidade, o balanço convidativo. Outro não poderia ser o seu lugar preferido. Lá pode ser encontrada nas horas mais ensolaradas, embalando o corpo no vai-e-vem do próprio impulso. Os cabelos chuviscados de flores miúdas, variando do grená ao verde claro. Algumas vezes, sozinha, devaneando... Outras vezes, brincando na companhia dos donos da gangorra. Os netos da parenta regulam em idade com a menina e estão em férias também. Moram na Rua do Lado. Razão principal dos quintais, pelos fundos, emendados. Podem brincar à vontade e brincam. Com a presença da pequena visitante, a diversidade arbórea assiste o trânsito intensificado entre as duas casas. As três crianças só botam a cara na rua de tardezinha, quando têm permissão de passear nas alamedas da pracinha. No centro. Não distante da casa. É só descer a rua, dobrar a esquerda na primeira esquina e seguir direto pra chegar lá... $\mathrm{O}$ jardim com as arvorezinhas aparadas abraçando a fonte... Chuá-chuá-chuá... Coisa boa! Vento fresco. Cheiro de flor. Namorados nos bancos. Tempo de sobra para brincar até cansar. Voltar, na hora obedecida em casa. Essa é a vida de Luise até a chegada do Tio. 
Eufrísio chega para buscar a mãe e a sobrinha. Todos se emocionam com o reencontro esperado. Com ele, o genro. Discreto. Sorriso franco. Desperta simpatia. Os dois falham na cidade um dia. Fazem compras. Resolvem negócios. Vó Mina faz preparativos para a viagem. A partida se dá ao alvorecer do terceiro dia. Os adultos cada qual no seu cavalo. Luise... "Upa!" Na garupa do Tio. Arranjaram um cavalo só pra vovó e a danadinha até que vai bem, podia imaginar? Alcançam o campo com o dia clareado. Luise aspira o ar fresco. Absorve a paisagem. Arvorezinhas retorcidas. Flores. Que cores! A corrente prata do corguinho. Capim orvalhado. $O$ vento penteando as palmas dos babaçus. Lindeza. Eta mundão. Parece não acabar mais. Descampado. Terra vermelha. Ao longe, morrinhos azuis ondulantes. Rajas vermelhas espicham. O sol acorda. Não demora é bateia inteira polvilha ouro por todo lado. Coisa bonita de ver. O gado pastando manso. De vez em quando, casinhas de barro, telhado de palha, porta de embira... Será que tem gente morando? A certa altura, o Tio aponta um arvoredo.

- Lá, vamos descansar e almoçar.

Pelo meio do dia, adentram a frondosidade. A visão do rio largo, límpido, raso subitamente descortinado... Ah! A respiração da menina suspensa por um momento. Posta no chão, ela corre para a margem, olhos pregados no coruscar da água pela luz filtrada. Pequenos seixos rolam entre pedras grandes vetustas. Meninos brincando... Mães vigiando. Como "barulham!” Os homens dão trato aos cavalos. A avó tira a matula dos embornais.

— Luise, vem.

Última a se sentar para comer, só depois de provar a paçoca de carne pilada, a menina percebe a fome que tem. Passarinhos trinam algazarra.

— Luise, olha lá a casinha do João de Barro.

- Onde, Tio?

— Ali... Naquele galho... Do lado das “fror” de parasita... Tá vendo? 
— É mesmo. Lá, Vó! Tão bonitinhos...

Todo o mundo por um tempo de pescoço espichado para a obra do pedreiro.

— Aqueles ali... Perto do cipó... Ah... Fugiram. Queria saber se era o João e a Maria de Barro.

Fim do repasto. Os animais pastam. Os homens recostam nos troncos. Vó Mina lava as vasilhas. Luise anda sobre no rio de pedra em pedra, abaixando aqui e ali, tocando as pedrinhas. Tira uma fora para examinar de perto. A água escorrendo entre os dedos. Que fresquinha.

— Pode ser um 'pingo-d'água'.

— 'Pingo d'água'?

- Um tipo de seixo que costuma ser encontrado perto de pedras grandes com as pontas pra fora como essas daí... Os garimpeiros chamam de 'satélite' ou de escravo-de-diamante'. Quando acham diamante, quase sempre tem uma pedrinha dessas perto.

— Como saber se essa daqui é ou não é um 'pingo d'água?

— Essas coisas têm 'ciência' que só um minerador de verdade conhece. Um faiscador qualquer não tem como saber... Lá no Veríssimo, acharam um diamante enorme, um ferreiro levou ao fogo, depois à bigorna e estilhaçou a pedra toda.

- Oooh!

— Diz que ainda assim os pedaços renderam dinheirão.

Vó Mina sai com a capanga e vai recolher sementes de sucupira... "Um santo remédio!" Ela conhece tudo quanto é planta... cânfora, coité, artemísia, sabugueiro, pimenta cravo, canela... Luise com pedrinha na mão. Será você um pinguinho d'água... satélite de um rico diamante? Alisada desse jeito... deve ter sofrido, rolando por onde passou...

— Vamos embora, Luise! 
A menina vê todos montados, apenas o Tio espera por ela em pé, segurando as rédeas do cavalo. Ele alça a sobrinha para a garupa e para. Todos ouvem um tropel. Cresce. Aproxima. Traz quatro cavaleiros e meio, com o menino na garupa do cavalo que se adianta. Eufrísio apresenta Aulerindo Pompeu, dono da Fazenda Sucupiras para a mãe e a sobrinha.

- Povo brabo aquele lá de Catalão, heim, D. Mina?

O fazendeiro diz isso rindo, não espera resposta e engata outro assunto.

— O povo pode ser brabo... mas sabe fazer uma festa... Ah, isso lá sabe... Festa de N. Sra. do Rosário... Leilões... Novenas... Uma beleza!

- Outubro. Segundo domingo. Falta pouco.

— Bonito ver o povo da cidade e da roça participando... Tradição antiga... Meu pai conta que meus avós costumavam ir de carro de boi e se hospedar na cidade de dez a quinze dias.

- Desde que a Festa começou a ser feita na cidade, os fazendeiros das redondezas passaram a alugar casas e ficarem as duas primeiras semanas do mês dando folga aos empregados pra participarem dos festejos.

- Lembro que eram dois ternos de dançadores.

- Congos e Moçambiques.

— Os Congos são moços começando na Irmandade. Os Moçambiques mais experientes e credenciados.

- Ouvi dizer que pra ser Moçambique agora precisa da aprovação do conselho deles.

- São respeitados e considerados mais importantes porque dizem ter achado Nossa Senhora.

Na garupa, Luise, atenta ao que é dito.

- Se o Senhor for pra festa, Sr. Aulerindo, apareça lá em casa com a família.

Conversa encerrada. Despedidas cordiais. O fazendeiro toca para beira do rio, assoviando e imitando os pássaros. Nossos viajantes prosseguem na viagem deles. 
O cavalo do genro, na frente. O do Eufrísio emparelhado com o de D. Mina. Alguns comentários sobre o fazendeiro... "Político poderoso e influente na região" ...e o assunto migrando naturalmente para a festa.

— Mãe, como começou a Festa do Rosário lá em Catalão?

“A história ficou perdida lá atrás...Os dançadores mais velhos contam que os pais, avós e bisavós já tinham a tradição de festejar N. Sra. do Rosário quando vieram de Minas trabalhar nas lavouras de café, trazendo as crenças. O começo é contado de muitas maneiras...Uma delas fala de um descendente de alemão morador de Araxá, que mudou pra Catalão na intenção de crescer como fazendeiro. Naquele tempo, vinham muitos mineiros atrás de terras novas em Goiás... Pra a lavoura... Criação de gado... O homem era devoto N. Sra. Do Rosário e fez uma promessa pra Santa. Se bem sucedido haveria de fazer uma festa na cidade pra sua protetora como nenhuma outra tinha sido feita antes. Passaram uns dez anos. Ele próspero nos negócio. Enricou. Assentou. Casou. Teve filhos. Achou que era hora de cumprir a promessa. Adoeceu. Teve medo de morrer sem pagar sua dívida com a santa. Chamou o filho de nove anos à beira da cama. Passou pra ele a incumbência de cumprir a promessa, caso faltasse". Luise imaginava o menino... Sério, escutando o pai... Orgulhoso com a confiança dele... Preocupado em dar conta do que tava prometendo. " $O$ pai não sobreviveu. O menino cresceu. Bem sucedido. Casou com uma das filhas do vigário Luiz Antonio da Costa.” Vigário é padre! Não pode casar... Chiii... vovó se enganou e o Tio não percebeu? Ai--ai... Preciso conversar com ela depois. "Apreciador das festas em homenagem a N. Sra. do Rosário, tal como o pai. Na época, realizadas ora aqui e ora acolá nas fazendas das redondezas. Era senhor de muitos escravos, preparou um grupo de negros e mandou pra Araxá aprenderem as danças na terra do pai."

$\mathrm{Na}$ calma da viagem, Luise observa a paisagem e não deixa de prestar atenção ao que ouve... Qualquer um pode misturar e embolar coisas que guarda na cabeça. "Os escravos voltaram formados e ensinaram aos pretos das 
outras fazendas. Tudo pronto pra a maior festa em Catalão. O grupo enorme de dançadores treinados, divididos em dois grandes grupos de ternos - Congos e Moçambiques -, recebendo ordens de um 'Capitão', sob o comando de um 'General', colocados nas ruas, devidamente enfatiotados com as indumentárias apropriadas e os instrumentos. O padre discordou da festa."

- Ora... Por que, Mãe?

- Chamou de ritual pagão, brigou com o Coronel, fechou a igreja e sumiu com a chave.

- Não acredito. O filho ficou sem poder cumprir o compromisso do pai com a Santa, depois de tanto trabalho, dinheiro gasto e tempo perdido?

- Escuta só... O Coronel Augusto Neto Carneiro desabusado como qualquer coronel da época estava determinado a cumprir o prometido. Custasse o que custasse...

Mandou chamar o rezador de terços, Antônio Romualdo Fernandes, o conhecido Antonio Guloso, pra rezar as novenas e cantar as ladainhas. A porta da igreja foi arrombada e realizada festança enorme pra N. Sra. Do Rosário em Catalão. Promessa paga. Festa realizada todo ano na cidade.

Os viajantes seguem devagar. Luise escutando a conversa e observando ao redor... O gado pastando manso nas colinas... A terra revirada em alguns lugares exibindo matizes do rosa ao vermelho vivo... O sol rubro baixando no horizonte... Não percebe o tempo passar.

Chegam à casa dos pais do genro. Janta prontinha, esperando. $\mathrm{Na}$ ida do filho e do sogro para Formosa, a dona da casa ficou prevenida do dia da volta e pôde preparar boa comida goiana. Nas panelas... Pequi, "gueiroba”, arroz, feijão, macarrão, carne frita aos pedaços, verduras, legumes, conserva de jurubeba... De sobremesa, doces caseiros, queijos e frutas, degustados. Alegria aconchegante. 
Companhia de parentes e amigos. Bela tarde iluminada pelo poente. O tema principal da conversa, o encontro com Aulerindo Pompeu e a Festa do Rosário.

Passando com uma pilha de pratos nas mãos, a mãe do Genro vê Luise comer com saudável apetite e pergunta:

- A comida tá boa, fia?

A resposta é sincera.

— Muito boa mesmo. O frango com açafrão, então... Bom demaaais!

- Ha-ha-ha... Frango não, tatu.

— Tatu... Nossa... É tatu mesmo!? A carne é igualzinha a de frango!

- É gostoso, né?

A mulher se afasta rindo.

—Chamam tatu-galinha pra não confundir com o outro.

Pela primeira vez, Luise ouve a voz do rapazinho, olhando para ela de longe o tempo todo.

— Outro... Que outro?

- O tatuteba...

- O genro passa na hora e dá um piparote na cabeça do irmão mais novo, corrigindo.

— Tatuteba não, coió! Ta-tu-pe-ba.

Luise curiosa.

-Esse tatupeba... tem gosto bom?

— Sei não... Esse gente não come... Ha-ha-ha... Ele é que come gente.

- Hã...??

- Defunto enterrado. 
O assunto haveria de render mais, não fosse a pressa do tio em vencer as poucas léguas que faltam para chegar a casa dele. Despedidas. Promessas de breve reencontro. $\mathrm{O}$ grupo de cavaleiros engolido pela escuridão.

De noite, no mato, sombras e sons diferentes. Perturbadores. O sopro da brisa bulindo com as folhas... $\mathrm{O}$ estranho pio de um pássaro noturno... O galho escuro atravessado. Luise tenta controlar o medo... Era só um cipó, sua boba! Não uma cobra à espreita, viu? O Tio disse que a distância era curta. Para a sobrinha, parece um caminho sem fim. A conversa entre mãe e filho distraia um pouco. A Festa ainda dando 'pano pra manga'. Ainda bem.

- Foi sempre realizada naquela igrejinha?

- Não, não... A primeira igreja construída em homenagem a N. Sra do Rosário, foi a "Velha Matriz", conhecida naquele tempo como Capela N. Sra do Rosário. Ainda não tinha luz elétrica. A usina da Cia Prada, na Fazenda Quigila, no Córrego Pirapitinga só foi inaugurada em 1923. Mas era uma beleza ver o largo todo clareado pelas "luminárias" de cascas de laranjas cortadas ao meio cheias de azeite presas nas pontas dos bambus fincados no chão... Duravam de oito a dez horas com o pavio aceso.

Luise encantada chega a esquecer o medo... Lindeza... Que cheirinho bom devia ser... Conhece bem os ritos das festas da sua cidade, pode ver e sentir o que Vó Mina vai contando. O medo volta e atrapalha. E se uma onça... A menina toda encolhida na garupa do cavalo. Escuridão profunda nos quatro cantos. Essa lua nova. Se fosse cheia bem ia ajudar... As pontas dos galhos das árvores mais altas brilhantemente prateadas... Aqueles feixes de luz que parecem brotar do chão e cortar o escuro de baixo pra cima... "Na última novena, a procissão dos balõezinhos saindo da casa do mordomo pra porta da igreja... A 'levantação' do mastro... As girândolas ${ }^{9}$ enfeitando o céu." Não sei o que é girândola... Preciso guardar esse nome, perguntar pra ela depois. "Espiral. Cruz... Flor... muitos formatos. A apresentação acabava sempre com uma

\footnotetext{
${ }^{9}$ Roda ou travessão em que se reúne certo número de foguetes, que sobem e estouram simultaneamente.
} 
girândola especial, mais bonita, risco diferente... a estampa do santo da Festa no centro... No final, grande 'morteiro' anunciando o espocar de foguetes." Sei bem como é... Atordoa os ouvidos... Escurece o céu de fumaça... Gritaria de criança... Correria... Adultos de caras assustadas... Nem parecem prevenidos.

— Quem fazia aquele trabalho?

- Primeiro, o Joaquim Fogueteiro era o artista das girândolas. Depois, o Totônio Fogueteiro, dono da maior fábrica de foguetes em Catalão.

- E as barraquinhas?

—Começaram a aparecer depois de 1930. No dia da festa, missa cantada, "tiração" de esmolas...

— Como é essa "tiração de esmolas?"

"A moçada saía da casa da festeira repartida em grupos de duas moças e um rapaz, elas com salva de prata ou prato de vidro, eles com a bandeira do Santo da Festa. Percorriam as ruas do centro da cidade... Batiam nas portas... Pedindo donativos pra Festa. Todos se esforçando para angariar a quantia maior. $\mathrm{Na}$ disputa, paravam pessoas... Prendiam com jeitinho cativante... Os pedidos insistentes quase sempre atendidos. Lembro uma mocinha... Como era esperta! Desempenhava. Sorriso encantador... Olhar da própria santa... Não precisava insistir... A salva dela logo enchia".

Luise amedrontada presta atenção nas vozes e nas batidas dos cascos no chão. Qualquer ruído diferente poderia denunciar algum perigo se aproximando. A monotonia do silêncio escuro e pesado quebrada pela ondulação de algum riachinho... Se algum tamanduá bandeira de unhas compridas passando pra beber água abraçar algum de nós por traz... O pio de um pássaro distante... Se um gavião enorme...

"Depois, a reunião na casa da festeira, o farto café... biscoitos, doces, licores... A dança pelas horas da tarde... Às quatro, saia a procissão solene... Anjos... Virgens... Roupas novas...Caras e ricas... Alguns, descalços, cumprindo promessas. Andores, seis ou oito, muito bem enfeitados de todos os santos 
festejados durante o ano. O padre debaixo do palium carregado pelas autoridades, senhores importantes convidados antes. Durante a procissão, o festeiro, com a cesta grande, repartindo os cartuchos de amêndoas entre anjos e virgens. Dia de acontecimentos importantes. Muitos casamentos e batizados realizados. Motivo de encontro das famílias catalanas".

Lá pelas tantas, o descampado. Eufrísio aponta a claridade tênue na noite escura:

- Chegamos.

Luise divisa a casinha ao longe, fincada em campo aberto, e respira com alívio... Até que enfim!

Do interior, o brilho de uma chamazinha guia o caminho e recorta duas silhuetas na porta. Odília e Ana recebem os viajantes. Água quente para o asseio. Camas prontas para o merecido descanso.

No dia seguinte, última a acordar, Luise já levanta sentindo o cheirinho do chá de canela, o favorito da avó. Pergunta. Responde. Saboreia o mané-pelado.

— O bolo tá tão bom!

- Deve ser porque foi feito com mandioca colhida na hora.

Vendo da porta o mandiocal e ansiosa para ver o lugar à luz do dia, na primeira oportunidade que tem, a menina escapa pela porta da cozinha... Que beleza! O quintal bem plantado se espraia e desaparece em declive.

- Leva direto pro rio.

A prima seguira a priminha.

- É muito bonito.

Saem caminhando juntas. A prima mostra o curral. Luise sobe na cerca de madeira. Sentado num banquinho tripé, o genro puxa alternadamente as pontas do cacho róseo, que emerge do alto das pernas traseiras da vaca. No movimento 
ritmado das duas mãos aperta e afrouxa as tetas imitando a sucção do bezerro. $\mathrm{O}$ jato de leite jorra certeiro dentro do balde estrategicamente situado. A menina vê a cara resignada do animal... A coitada parece acostumada. Ela dá boas risadas vendo os bezerros apartados, inquietos abanando os rabichos e dando pinotes para todos os lados... Reclamam na maneira deles. Distraída não vira a prima sair. Perto da vaca, Ana mergulha uma caneca no balde aos pés do marido. Volta. Oferece a espuma branca para a priminha, com expressão convidativa.

- Prova.

O líquido espesso e morno tem sabor inigualável.

—É muito diferente daquele que o leiteiro entrega em casa.

Um leve sorriso de agradecimento baila no rostinho sereno. De repente, sério. Por que será que antes de virar a cara o genro fez aquele ar de... debochadinho? A priminha desce da porteira ressabiada e dá de cara com a prima apontando para ela sem conseguir disfarçar o riso.

— Não é nada não, Luise... A gente tá achando graça do seu bigodinho de leite novo.

A menina acaba logo com a "sem-graceza" dos dois, limpando os lábios com as costas da mão. O rapaz continua na ordenha do dia. As primas seguem rodeando a casa. Param na frente dela. Luise admira o campo de gramínea estendido como um tapete sob o sol luminoso.

— Deve ser bom morar num lugar calmo e bonito como esse.

- A gente acostuma.

- Será... Nem sempre é igual... Olha aquele morro arredondado... As plantas miúdas subindo e descendo até sumir na barra do arvoredo lá na frente... Onde a neblina tá desmanchando... De noite, vai ser diferente. Debaixo de chuva, também. Não, nunca é igual. Pra gente acostumar. 
Luise aprecia a belezura... Some da vista! Dispõe-se a prosseguir. Do outro lado da construção, o pequeno bosque de árvores copadas oferece sombra generosa convidando a boa prosa. O fim do contorno sela a amizade de Ana e Luise, já antes sinalizada por recíproca simpatia. Tornam-se grandes companheiras. A prima se encaixando na experiência de irmã mais velha, levando a passeios, contando histórias... A priminha aceitando de bom grado a troca do papel que desempenha em casa. Ao saber a idade de Ana, Luise reage.

— Quinze anos e já casada?

- De pouco.

- Ele tem quantos?

— Quase vinte.

Depois do almoço, Luise empoleirada no jirau. Pernas cruzadas. Prato largado no colo. Observando a cena familiar a pouca distância. A avó conversa com o filho ao redor da mesa... Sossegada. Alegre. Ana lava as vasilhas trocando olhares buliçosos, vez ou outra, com o marido... Parece que têm uma língua só deles. A tia descasca alguns dentes de alho, põe dentro do almofariz e começa a socar. "Por que não senta e descansa um pouquinho, Odília?" A Tia põe força no braço. "Vou temperar a carne pra de tarde". Aos olhos de Luise, a vida ali aparece sempre serena e harmoniosa. A casa é humilde. Poucos móveis. Nos quartos, só as camas e as arcas de roupas. Na cozinha, a mesa, os tamboretes de couro e o jirau. Serve pra sentar ou dormir. Na sala, os dois bancos compridos encostados nas paredes, a máquina de fiar e o banquinho. Parece que não precisam de mais. Na singeleza, muito que-fazer. Todos se ocupam. Ana e Odília cuidam da casa, da roupa, da horta, da comida. Quase tudo é feito aqui mesmo... Pão, bolo, biscoito, farinha, polvilho, sabão... O tio e o genro tomam conta do gado, da roça, do quintal... Parece que se dão bem. Sem tomar muita liberdade um com o outro. A comida é abundante. Muitas vezes enriquecida com caça e 
pesca. A carne, ontem, tava muito boa. Achei que era de vaca. Mesmo gosto e parecença. Tinha visto as mantas secando ao sol. Pensei que fosse mesmo. Terminei de almoçar. Fiquei sabendo que não era. $\quad \mathbf{E}$ a vovó, heim... Não come ovo, carne de boi, de peixe ou de frango... Provar a de anta? Nem pensar. Nisso, é bem sistemática. Se alguém misturar as colheres de tirar as comidas, já não quer de nenhuma. Deve ser por isso que, esteja onde estiver, tá sempre ajudando na cozinha. Ainda bem que gosta de cozinhar. Mesmo não comendo disso ou daquilo, não importa de preparar pros outros. A minha vozinha é cuidadosa. Finca tento nas panelas e garante que nada vai ser misturado. Ela come uma carninha de porco... Um rolinho de linguiça... Um pedacinho de suan... Um pezinho de gambito... Até uma pacuera ou outra entra lá em casa de vez em quando... É estúrdio ver a cabeça do porco despelada, olhos, dentes e tudo ligada às fressuras... fígado, coração, bucho... agarrado no tubo que sai da garganta... Quase tudo, aproveitado. Mas, Vó Mina gosta mesmo é das verduras. Pega uma coisinha aqui, outra coisinha ali, outra acolá, umas ervilhas, umas ervas, brotos da aboboreira que chama de cambuquira... E olha que comida simplesinha e gostosa! Tanto elogio. Será que a tia Odília se incomoda com isso? Às vezes, acho que muda de cara... Bate as tampas das panelas... Deve ser impressão minha. Força e jeito dela mesmo. A Mãe acha que a Vó come pouco. Tem medo que fique fraca. Que nada. A vovó é mais forte do que ela. Quase não fica doente. Nunca tem cárie. A vista é boa. Ainda faz crochê à luz de lamparina, sem precisar de óculos. Algumas rugas. Poucos cabelos brancos. Não gosto do jeito que prende. Quando as mulheres começam a ganhar idade, torcem o cabelo e prendem com aqueles grampos enormes... A vovó... A D. Quetita... A D. Lizandra... A tia Odília... Todas com o mesmo coque-de-vó. Não deviam fazer isso. Dá ar de mais velha. Odília faz o café. Cara séria. Bate a colher na panela. Mexe nos tições. Dá um soprão. "Eta fogo lerdo", resmunga. "Precisa de mais lenha, Odília?”, o marido se apressa em perguntar. "Lenha tem bastante. Deve tá é molhada", responde. Distribui as xícaras pela mesa. "Não vou querer", diz o marido. "Uai, D. Mina... o filho tá ficando igual a mãe. Daqui a pouco, só vai querer comer carne de porco, não é "Ofrísio". Acho que a tia Odilia só tá brincando. A Vó e o Tio não precisavam ficar vermelhos e sorrir amarelo desse jeito. 
$\mathrm{Na}$ tarde passante, o quadro familiar aos poucos se desfazendo... $\mathrm{O}$ casalzinho escapole... pensando decerto que ninguém viu. $O$ Tio não espera pelo genro... sai de fininho. A nora e a sogra se encaminham para a sala.

— Ainda com esse prato, na mão, menina... Com efeito, Luise! E não vá lá pra fora, ainda não. O sol tá muito forte.

-Tá bom, Vó.

Vó Mina pega o crochê e se acomoda num banco. "Sabe Odília... essa menina cisma demais... às vezes me preocupa". Odília no tamborete da roda de fiar com uma escova de prego e madeira em cada mão. "Quando crescer isso passa, vai ver". Pega emboladinhos de algodão dentro de um cesto e desenreda passando de uma escova para outra. Penteia a fibra até ficar leve e solta, flutuando ao sopro da respiração... que nem algodão-doce... dá até vontade de comer. Coloca noutro cesto. Parece o berço de uma nuvenzinha desavisada. A tia pressiona o pedal. A cantilena monótona da roca movimentada ganha o ar. Arrancando o algodão cardado, pedacinho a pedacinho, Odília vai fiando e emendando. Luise fascinada vendo o brilho e a maciez se transformando num fio resistente. O lamento da correia de couro cala. Odília arreda o tamborete de modo a ficar entre dois outros cestos. Um está vazio. O outro, cheio de algodão do jeito que foi colhido do algodoeiro. Ela vai pegando as caixinhas secas e semi-abertas, tirando o conteúdo de dentro e jogando no que está vazio.

— Tia Odília... Posso te ajudar?

— Pode sim, filha. Ocê descasca e eu descaroço.

A menina puxa com agilidade o recheio das cápsulas, sentindo a diferença de textura entre o chumaço macio e a casca áspera. Que coisa mais bem feita essas caixinhas protegendo o algodão dentro... 'O que é que é: uma caixinha 
de bom parecer, não há carapina que possa fazer?' Amendoim. Mas bem poderia ser algodão, paina, jatobá... A natureza é misteriosa. Luise vê a tia pegar emboladinhos recém-descascados e colocar na abertura da pequena descaroçadeira. Girar a manivela e pressionar o algodão. As sementinhas negras e lustrosas saltam libertas pelo chão. A menina move os lábios, repete a frase que aprendera no passado. "A boa semente é a primeira garantia da boa colheita" e não emite som. Para o que faz, agacha e começa a catar as bolinhas mais perfeitas, achando que... o tio Eufrísio vai precisar das melhores, para plantar. Como pode um pé de algodão inteirinho caber dentro de uma bolinha seca, dessas? $\mathrm{Na}$ imaginação, vê o tio abrir pequenas covas... Jogar punhados de sementes dentro. Cobrir de terra fofa e vermelha. Elas vão ficar enterradas na escuridão por uns dias. Não quietas. Trabalhando muito pra romper a casca... Sair da terra. Ser alcançadas pelo sol. A escuridão garante a vida. Mas precisam da luz pra crescimento. No dia certo... Lindeza! A plantação cheiiinha de pequenos brotos. Crescem arvorezinhas verdes... Abrem flores amarelinhas... As flores enfeitam. Dão alegria. Costumam ser lindas! Pétalas macias... Brilhantes... Cheirosas... Encantadoras. Nem todas são bonitas. A flor da bananeira é muito carnuda... Meio indecente. A flor é diferente da folha. Mesmo depois de seca, pode continuar bonita. Manter a forma. Quem vê a flor não lembra as raízes, debaixo da terra suportando a planta... Sujas... Nuas... Que nem vermes. A flor também sai do esterco. Parece tão pura. Dura pouco. Murcha. Apodrece. Envelhece. Rebenta no caule. Feia. Nojenta. Desaparece. O algodoeiro frutifica caixinhas fechadas... Elas secam e se abrem, oferecendo generosamente os preciosos chumaços... Alguém colhe. Descasca. Descaroça...

— Só falta cardar e fiar.

Com o sol mais fraco, Luise é liberada para sair correndo pela porta da frente. A basta cabeleira ao sabor do vento. Qual direção tomar? Para. Olha para 
um lado... Olha para o outro... Melhor deixar a sorte decidir. Usa o indicador como pêndulo e recita: "A mamãe mandou dizer pra escolher esse daqui." Questão resolvida. Corre lépida para o rumo que o dedo indicou. Alcança a barra do arvoredo. Desacelera. Embrenha. Um pé de cajuzinho-do-mato, carregadinho! Saboreia as frutinhas gulosamente... Huuumm! Recomeça a andança até ser atraída por novo achado... Araçá! Fadinha-do-campo! Gravatá! Mais tarde, acha que já é hora de voltar. Ganha pasto aberto. Corre desmimetizada para a pequena colina. No alto, abre os braços. Rodopia. A natureza dá tanta alegriiiiia... Senta. O olhar abarca a casa solteira. De longe, parece menor. Deita. Pega um "capim-paininha". Mordisca. O céu coalhado de carneirinhos, esconde-escondendo o sol vespertino. O pensamento da menina flui livre de interferência, como alguém que faz uma colcha de retalhos misturando, sem escolher, simples quadrados e elaborados fuxicos... A Ana é boazinha demaais, comigo. Mostra as coisas. Explica. Ensina. Tem paciência. Leva pra passear. Gostei de conhecer a amiga dela. Noraldina. Mora longe. Mas indo a cavalo, deu pra a gente aproveitar bem a tarde. Noraldina e Ana conversaram, riram e brincaram, assando quebrador e sequilho. Gosto de biscoito, mas prefiro frutas. O mamão tirado do pé madurinho tava mesmo uma delícia. Lá em casa, a Mãe tira de vez, risca com a faca e deixa o leite escorrer. Amadurece mais rápido. $O$ gosto não é o mesmo. As duas amigas conversaram e riram o tempo todo... Mexericos... Leva-e-traz... Enredos... Não sei.

— Luiiise!

A menina cospe fora o capim-paininha. Levanta num salto. Corre em direção a casa.

— “Toiiindo", Vóóó...

Distraída, não sentira o tempo passar. No horizonte, o sol já se despede. O tio, na frente da casa, já voltou da lida... O genro vem chegando, no galope do seu baio. Ela corre e tenta acompanhar o cavalo... muito mais veloz. Perto de casa, o cheiro bom da comida vem de dentro encontrá-la. Percebe que tem baita fome. $\mathrm{O}$ espírito já bem saciado pelo aprendizado do dia junto à natureza. O corpo 
desfruta com vontade a boa refeição. Entre parentes. Termina a janta. A conversa prossegue à luz da lua. Grilos cricrilam. Sapos coaxam. Aves piam. As vozes humanas se juntam à sinfonia. Até chegar a hora das bênçãos de praxe.

— Bença, Vó... Bença Tia, Tio... Boa noite, pra todos.

- Deus te abençoe... Lava os pés, primeiro.

No dia seguinte Luise mal acorda, sai correndo e vai se embrenhar no mato de novo. Quase perde o fôlego diante do pé da dormideira orvalhada. Bonito de doer. Para estacada, vendo as gotinhas brilhando sob o sol matinal... Pedrinhas de cristal. Toca um dos galhos com a leveza da borboleta e recita... Maria fecha a porta que o soldado em-vem... Maria fecha a porta que o soldado em-vem... A sensitiva encolhe as folhas. A menina finge acreditar que a planta obedece ao seu comando. Dia após dia, vai explorando as redondezas. Horas dedicadas à natureza. Observação. Convivência. Menos... "Não desça lá no rio, sozinha!" Luise não quer que ninguém saiba do seu primeiro sangue de mulherzinha. Nem mesmo a prima. Chegou de manhãzinha. Sem anúncio nenhum. Luise não se surpreendeu. Certa vez foi com a mãe ao consultório do Dr. Jamil e sentou na confortável cadeira da varanda espaçosa para esperar a vez dela ser atendida. Tinha uma senhora de meia idade, na frente. O médico abriu a porta do consultório, se despediu da cliente que estivera lá dentro e chamou essa senhora para entrar. Cabelo grande, negro, lustroso... Ela se levantou ainda com as pontas da saia ampla apanhada pelas mãos e seguras na altura das coxas. Antes que soltasse e caísse sobre a anágua branca, Luise estática e assustada pelo vermelho vivo que viu distribuído em muitos pontos da roupa de baixo. A mulher e o marido entraram no consultório. $\mathrm{O}$ médico fechou a porta.

— Mãe, a anágua dela tá cheia de manchas de sangue enormes!

— Pois é, minha filha, isso é uma coisa muito triste! 
Naquele dia, a mãe viu a chance de preparar a filha... "Todo mês, a mulher..." Ainda bem que aqui sobra algodão. Quando voltar pra casa, vou precisar de toalhinhas...

A menina prefere lavar a própria roupa. Desce junto com a outra, levando a trouxinha debaixo do braço. O mandiocal acaba de súbito. Começa a ladeira de pedra pura. Caminham mais devagar. Pisam com cuidado. Vencido o caminho pedregoso, água turva à vista.

- Ana, esse rio é muito largo.

— Largo e fundo. No tempo das águas, sobe muito.

— Enche de derramar?

- Nunca aconteceu. Costuma alcançar a altura daquela marca, no barranco, tá vendo?

- Que bom que a casa fica longe e no alto, né? Tem sucuri?

- Não aqui.

— Onde, então?

- Na Lagoa Feia tem sucuri morando. Muita gente já perdeu vaca e cavalo, lá na beira.

- Credo!

- Numa época de grandes enchentes, muitas sucuris foram vistas. Diz que uma foi encontrada com os chifres de um boi ainda pendurados na bocarra.

- Nossa Sra. d’Abadia! Como é que pode caber um boi inteiro dentro dela?

- Enrosca, aperta, quebra os ossos e engole tudo. É um bicho medonho. Pode chegar a mais de dez metros de comprimento. O trem é marrom, barriga amarelada, pintonas pretas nas costas, escamas na cabeçorra...

- E os chifres ficam...

— Do lado de fora até caírem de podres.

- Eca!

- Diz que come tudo quanto há: peixe, "passarim” que vai pegar peixe, burro, cavalo, boi que vai beber água... Tudo!

— Gente... Também?

- Já sumiram pessoas... Tem até o caso do Izé da Badia... Andava feito louco procurando a noiva por todo lado. Recebeu notícia de que a moça tinha sido 
vista na garupa de um cavaleiro. Achou que ela tinha fugido. Desistiu de procurar. No dia que mataram uma sucuri e abriram a barriga dela... Izé da Badia descobriu a verdade... As tranças da Maria foram encontraram dentro do bucho do bicho.

- Ah, não... Que tristeza...

— Quem conta isso é a Dona Aninha, lá de Goiás Velho.

Dias passados. Bastante roupa lavada. Diversas idas e vindas depois daquilo e Luise ainda estremece lembrando o que pode acontecer mesmo com quem tem experiência em lidar com o rio. Naquela tarde, ela e a prima desceram conversando.

— Que chão mais cascalhento!

- Quando chove é pior.

Ana começa a trabalhar à beira da largueza turva e silenciosa.

— Você não tem medo de lavar roupa aqui sozinha?

- Às vezes... Diz que é assombrado.

- O quê... O rio?

— É. D. Jaci, a vizinha que mora três léguas arriba, tinha uma cachorrinha que foi ofendida por cobra e morreu. Mandou queimar o corpo e jogar as cinzas no rio. Depois disso, nas noites de lua cheia, os ribeirinhos passaram a escutar latidos...

Ana acaba de contar a história... "Até hoje D. Jaci ainda chora inconformada.” Levanta para botar a roupa branca quarar numa pedra. Escorrega no sabão. Cai na água, arrastada. Tudo se passa muito depressa. Luise por alguns instantes, petrificada. Quer ficar e dar força à prima agarrada na saliência de uma pedra lutando para sair... Quer correr até o começo do caminho e gritar para cima pedindo ajuda. A menina reage, correndo e gritando pela margem... ora dizendo palavras animadoras... ora com as mãos em concha berrando por socorro. Não saberia dizer quantas vezes correu de um lado para o outro, até que a jovem e forte sertaneja conseguisse escapar por si mesma. A menina não quer saber de intimidade com o rio misterioso, que não exibe nenhuma transparência. Mas passados dias do episódio, já consegue se comportar com um pouco mais descontração à beira dele. 
— O peixe que a gente come... O Tio pesca aqui?

- Não. Aqui não é bom pra pescar. Mas, vou te levar num lugar...

—É mesmo? E a gente vai poder entrar na água?

- Vai sim. Lá é rasinho... Azulinho... Espera só. Não vou contar mais senão perde a graça.

— Nossa... Tô curiosa. Deve ser bonito, passaado... Quando a gente vai?

- Amanhã, vou ajudar a mãe com a farinha puba... Tem de ser depois. Depois de amanhã. Sem falta.

Debaixo das árvores de galhos entrelaçados no alto a menina não se contém.

— É um palácio natural, Ana!

A prima se diverte com o entusiasmo da menina.

— Ha-ha-ha... Não te falei que a surpresa ia ser boa?...

No emaranhado verde, trepadeiras e cipós não impedem a entrada do sol totalmente. Os raios filtrados entre folhas coruscam e iluminam o leito lodoso do riozinho raso e naquele ponto alargado. $\mathrm{Na}$ transparência da água cristalina peixinhos espertos nadam em cardumes em diferentes direções.

- Ma-ra-vi-lha de lugar.

— Luise vem cá. É assim que a gente prepara o anzol... Pega a minhoca...

- Ai...que nojo... Tadinha!

— Ara, é só um bichinho. Pronto. Vamos lá! A gente joga a linha, espera o peixe fisgar e puxa.

A prima bem tenta ensinar. O máximo que consegue é que a priminha pesque um minúsculo peixinho dourado que ao ser arrancado da água se 
contorcendo na ponta da vara faz a menina sentir tanta dó que passa a implorar a outra para soltar depressa. Vendo que Luise está mais interessada em desfrutar a beleza do lugar, Ana deixa a menina fazer o que quer e ela se esbalda de brincar.

- Ana, isso parece um sonho!

Tudo é sonho e um dia acaba. De repente, uma presença estouvada, inoportuna, incômoda tira a menina do seu estado de contentamento. Estraga tudo. Ocupa o espaço, na cabeça dela. Rouba o momento precioso. Devia ser só alegria. Ana preocupada quer saber por que a priminha mandou o riso para longe e ficou tão triste, de repente?

- O que foi, Luise? Que aconteceu?

- Nada, não... Quer dizer... Saudade. Lembrei que depois de amanhã a gente vai embora... e já estou sentindo falta de tudo.

"Não há bem que sempre dure nem mal que nunca se acabe". Viajando melancólica, Luise lembra o dito repetido pela avó com frequência. A menina sabe que é hora de voltar para a casa, para a mãe, para os irmãos, para as aulas... Já devem ter começado. Voltar também era bom. Mas estava sendo difícil deixar aquele paraíso. Despedidas tristes... Ana e tia Odília acenando da porta... Sumindo da vista... No pensamento, duas estátuas, lá atrás, paradinhas... Para sempre? Essas férias passaram muito rápido... Voando! Esquisito o tempo passar tão depressa e tanta coisa caber dentro dele... Vovó e eu, naquela manhã friinha, pegamos o trem na estação... Conheci os meni... Ah, tanta coisa aconteceu durante a viagem inteirinha, cabendo tudo dentro de um mês que parece ter sido bem maior... Luise é dada a ter pensamentos "complicados", dizem, e a "perder tempo", tentando entendê-los. Mas agora chamam por ela... O ipê amarelo! A paineira-rosa! ...quebrando a monotonia amarelo-acinzentada que predomina nessa época de estiagem. 
— Olha lá, Luise! Mais altas que você.

O Tio quer distrair a sobrinha e convida todos para desapearem. Descansarem um pouco. Ele é o primeiro a ver o bando de emas. Os dois grupos se avaliam à distância. A menina se encanta com o belo espetáculo das aves, mas não fica alegrada e não sabe fingir o riso... Como ficar feliz com uma coisa, quando a gente está perdendo... indo embora... e deixando ela pra trás? Observa as pernaltas, que nunca vira antes, mais quieta do que nunca. Mira especialmente a que está de lado e parece devolver o olhar para ela, naquele jeito que ave tem de espiar... As penas cinzentas das costas vão ficando cada vez mais clarinhas, quando descem pela barriga... É linda! Se pudesse falar... Como é possível ter tantos bichos diferentes no mundo... Mamíferos, aves, peixes, insetos grandes, pequenos, pequeninos, alguns até invisíveis...

- Upa!

O Tio torna a acomodar a menina na garupa. Aqui mesmo... Tem animais de todo jeito e tamanho... formiga, tatu, paca, capivara, tamanduá-bandeira, onça-pintada, anta, vaca, cavalo, coruja, arara, gavião, urubu, traíra, lambari, jacaré... sucuri! Ah, não dá pra pensar em todos, não. E no mundo inteiro, então? Por que será... Ara! Não adianta ficar perguntando. Ninguém sabe mesmo. Se eu perguntar, vão me responder... 'Mistérios'. Como sempre. A menina se recolhe nalgum cantinho de si vendo a nuvem de poeira levantada pelo galope dos animais. Num céu extremamente azul o sol na sua ronda contínua, escaldando a tarde passante. Aos poucos, o horizonte ganhando tons de... Laranja... Tangerina... Caqui... O que é o que é... É ouro... É prata... e não é ovo? É o sol trocando de lugar com a lua. Ele veste vermelho viaja pro Japão, ela fica no lugar prateando a escuridão... 
Os viajantes chegam a Formosa com as estrelas. Ficam apenas por um dia. Por causa do ajuste antecipado do tio com o dono do caminhão. Vai sair na manhã seguinte, passar por Catalão, deixar a mãe e a sobrinha. Com isso, Vó Mina pôde aproveitar uns diazinhos a mais com o filho e fazer pequena economia. A estada breve não é boa para Luise. Tudo com o gosto horrível do adeus. No balanço, sente falta dos meninos... "Foram pra escola." "Pracinha em véspera de viagem? Não convém. É preciso deitar cedo.” A saída se dá ao alvorecer. Despedidas apressadas no escuro. O caminhão ronca e rola pela estrada afora. A menina tresnoitada. Tem sono. Não consegue dormir. Lá vai a carinhade-peixe-morto vendo o clarão crescer aos poucos na barra da serra... Aumenta... Aumenta... Aumenta... Surgem os reflexos da bateia dourada. Vai polvilhar ouro no sertão o dia inteiro. Agora, tudo o que a vista alcança é secura. O caminhão diminui a marcha, desviando da buraqueira, o barulho diminui, e a menina consegue escutar a voz da experiência.

— Esse é o pior mês da seca. Em outubro começa o tempo das águas e tudo volta a ficar verdinho.

Só mesmo um entendido para falar com convicção sobre o reverdecimento daquela sequidão. Quem nunca tivesse visto poderia duvidar facilmente que aquilo ainda tivesse vida. Até mesmo Luise, nascida e criada na região, pode ser surpreendida com a visão repentina. Virgem! No meio da secura, o amarelo intenso refulgindo. O algodãozinho-do-cerrado. Acetinado. Fresco. Esplêndido. De tão vibrante, chega a ferir as retinas. Parece irreal. Miragem. Milagre? Vai saber. Mais um mistério da natureza. Diante de tanto viço e beleza a menina não se contém. A flor e o delicado botão passam tremeluzindo diante do rostinho empoeirado, riscado, salgado... O caminhão roda, roda, roda... Levanta a muralha de poeira vermelha e deixa para trás, por onde passa.

É quase noite quando os viajantes exaustos descem no lugar do pouso. Dormem na casa de uma mulher caprichosa. Pena levantar tão cedo no dia seguinte. Difícil deixar os macios lençóis, o perfumado travesseiro recheado de 
paina e flores secas. Há longa distância a ser percorrida. É preciso aproveitar o fresco da madrugada. A secura dos pastos parece aumentar à medida que avançam. O motorista estava certo. Antes mesmo do meio dia o calor já é forte na estrada. Na paisagem... Capim seco... Vegetação amarelada... Mais nada. A monotonia quebrada pelo o sol esconde-escondendo nos troncos ressequidos. Quando se põe, a noite friinha toma conta do sertão. "Olha que luona, Luise!" "Poucas estrelas." "Lá longe, imenso clarão". "Queimada." "Nessa seca... Tava demorando." Pela encosta, labaredas avançam crepitantes ao sabor do vento. Colunas rubras. Formação horizontal, traçando celeremente tudo o que alcança... Dragões enfurecidos investindo... Vomitando fogo... Uma nuvem enorme se eleva. Os olhos ardem. Fica cada mais difícil respirar... Soltando fumaça pelas ventas. Uma ave mergulha e tornar a subir rapidamente para o negrume. Gavião preando outra ave... Será aquela ali... Perdiz? Codorna? Voando baixo desse jeito... estar caçando inseto. O maior caça o grande... O grande caça o pequeno... Mistérios. Muralhas vermelhas serpenteiam morro acima e morro abaixo. Fagulhas levadas pelo vento. Nascem novos focos. Animais em fuga, esbaforidos. Luise olha para o céu. São Jorge trava a eterna luta... Não pode dar conta de todos, né? O veículo ronca, ronca, ronca. Passa muito tempo até a menina escutar, aliviada, o motorista falando que estão chegando ao pouso. Dessa vez, uma fazendinha à beira da estrada. Luise acha diferente dormir no couro de boi, estirado na cozinha. Não incomoda de ter que sair cedinho. Enjoado é aguentar o caminhão indo devagar, por causa dos buracos. Do outro lado da estrada, chamas ainda crepitam no campo seco. O caminhão segue sacolejando. Bem mais adiante já não se vê mais o fogo. Apenas o manto negro estendido por onde ele passou. Pretume de piche. Visto por muito tempo também nas estacas que seguem dividindo os pastos, até que... Finalmente! No chão crestado de pouco... No meio da cinza negra... Aqui e acolá... A vida rebrotando em plantinhas... A menina sabe... Não vão demorar a florescer. Lá longe... Perto das grotas o capim se mantém fresco... Tem sempre algum animal escondido. Mais adiante... Umas poucas arvorezinhas estendem seus braços raquíticos. Sombreando o fiozinho prateado, que serpenteia e leva vida ao terreno recoberto de viçosas pastagens. O mesmo riachinho alimenta a baixada pantanosa e o bosque de Buritis! Cresce sob a sombra fresca das árvores maiores que margeiam sua trajetória... e... alarga no ribeirão que corre agora debaixo da ponte 
que o caminhão atravessa. Não posso esquecer nada dessa viagem. Preciso guardar tudo, desde o começo... A manhã friinha na estação... O trem chegando... Os meni... Ah, muita coisa! Cabendo tudo dentro do pouco tempo de um mês... Se eu tivesse ficado em casa sem viajar nem nada... Esquisito isso... Viajando... De cá pra lá... De lá pra cá... Eu pude ver e aprender coisas diferentes... Tenho muito pra contar... A Helena e a Cecília ficaram lá na nossa rua, só brincando e vendo as pessoas que a gente conhece... Pensamentos vêm e vão. A menina meio confusa. Ora! Tem certa percepção de que está voltando mais rica do que partiu. Num cantinho de si, um tesouro a ser partilhado. $\mathrm{O}$ carro continua a rugir dificuldade. A certa altura, Luise começa perscrutar o horizonte, em busca de alguma coisa... Nada ainda. Está ansiosa. O que procura não pode mais estar muito longe. Não desiste. Mantém os olhos pregados nas árvores, passando depressa e ficando pra trás. Não demora a ser recompensada pela persistência.

— Lá ela, Vó! Brincando de esconde-esconde, com a gente... Não parece uma linda pombinha?

Vó Mina olha na direção apontada e visualiza o Morrinho do São João. A pequena branca capela em cima dele parece vir apressada ao encontro das duas, dando boas-vindas. Avó e neta se entreolham. Sorriem satisfeitas. Estão em casa outra vez.

40

Nos dias que seguem, Luise dá duro nos estudos para tirar o atraso das aulas perdidas. Vó Mina deu 'um pulinho' a Goiandira para levar encomendas da D. Irene para a D. Maria e contar as novidades da viagem. Foi 'num pé e voltou no outro'. Está em casa, quando Marizé chega da rua esbaforida e grita para Luise no portão: "Hoje não vai ter aula, o Presidente morreu." O quê?! A menina leva um choque. Tem a cabeça invadida por uma imagem... O Cara-feia! Sai correndo 
para dentro de casa. Vou contar pra vovó. Atravessa a sala... Chega à cozinha... Escuta uma voz compungida contando para as panelas... "...nessa manhã de $24 \mathrm{de}$ agosto, suicidou-se..." Suicidou?! Ergue o rosto. Fixa o olhar atônito no rádio no alto da parede suportado pela prateleirinha suspensa. "... em seus aposentos no Palácio do Catete, desfechando um tiro no coração, o Presidente Getúlio Vargas deixou uma carta-testamento com final extremamente dramático:" 'Lutei contra a espoliação do Brasil. Lutei contra a espoliação do povo. Tenho lutado de peito aberto. O ódio, as infâmias, a calúnia, não abateram o meu ânimo. Eu vos dei a minha vida. Agora vos ofereço a minha morte.", Brevíssima pausa, e o locutor prossegue. "Nada receio. Serenamente, dou o primeiro passo no caminho da eternidade e saio da vida para entrar na história". Tom de voz baixo. Respeitoso. Apropriado para a gravidade do momento. A menina escuta. Sobrancelhas franzidas. Seja por conta da estática ou por não poder apreender o sentido de alguns vocábulos mais sofisticados, não alcança a inteireza do que é dito. Mas não é impedida de captar a essência da notícia. A palavra suicidou permeia os pensamentos dela, levando a fazer conexões... Ela escutou. Retoma o caminho, vagando como uma bolha de ar, buscando a avó. Encontrada no quarto, sentada na cama, Vó Mina parece alheia a tudo ao redor. Acompanha silenciosamente a trajetória do olhar vazio, que parte do velho rosto cansado e se perde no regaço... Faz tudo para evitar assustar a avó, e a neta é quem leva o susto: Hã?! O tubo de creme dental... Amarelo... Letras verdes... Meio espremido pelo meio... A escova de dente gasta... Reconhece os objetos nas mãos enrugadas frouxamente abandonadas no colo da avó e vai sendo gradualmente tomada pelo tempo atrás... Menininha... na casa de antes...quantos anos? Ainda não tinha os irmãos... Se quando a Pitida nasceu tinha quatro, então, devia ter três... três e meio talvez... Acordada no meio daquela noite por sons estranhos... "Mãe!" ...desce da caminha... sai do quarto. Altas vozes, na cozinha. Alguém chorando! A mãe? A avó? O peso aperta a barriguinha. Quem? Aparece sempre que alguma coisa ruim está acontecendo. As duas? Desde que o Tio cedera o quarto para ela e a mãe, dormia na cozinha. De onde vem horrível barulho. Uma coisa grande deve tá acontecendo lá... A maior de todas? Àquela? Cadê o Tio Eurípedes... A menininha é tomada pelo medo. Ela anda. Ela para. Ela treme. De alguma forma sabe que dali para frente, a vida não seria a mesma. Ela anda. O coração bate forte... Tum! Tum! Tum! Ela para. A cabeça 
tenta cantar a cançãozinha... Meu limão, meu limoeiro... Anda... Para... Anda... Para... Já pode ver tudo... O vai e vem desesperado da Mãe e da Vó cegadas pelo pranto se esbarrando... Levam toalhas secas para a cama... Trazem de volta encharcadas... Sangue! Nenhuma delas parece se dar conta da presencinha, trêmula, encostada na parede fria, percebendo que o terrível barulho rouco é a respiração do Tio gorgolejando jorro vermelho e empapando tudo.

- A escova e o dentifrício dele, Luise.

O fio de voz da avó com as mãos estendidas faz a menina do presente articular a pergunta.

— Por que ele fez aquilo, Vó?

- Ninguém nunca soube, minha filha. Parecia tão bem. Chegou do trabalho, pegou você no colo, saiu para o armazém...

As palavras de Vó Mina trazem imagens da tarde remota, sendo reconstituídas, para a menina. Nítidas, como se estivesse vendo um filme... Pode se ver e se sentir menininha caminhando pela rua nos braços do Tio... Entrando no armazém da esquina... Descendo do colo para o chão. Parando. Olhando ao redor... Quantos objetos expostos! Começando a caminhar. Devagar. Seguida a meia distância. Parando de vez em quando. Espiando de perto uma coisa ou outra. Metendo a mãozinha nos grãos de feijão num saco em pé aqui. Tocando os de café noutro saco ali. O chapéu de palha! Especial interesse. Vira para trás. Ressabiada. É incentivada pelo sorriso aberto do Tio. Retribui. Não hesita mais. Experimenta. Ar de felicidade. Olhos que brilham. Prossegue. Sempre seguida de perto. O Tio separando tudo que ela mostra ser de mais agrado. Dá a volta na loja inteira. Termina as escolhas. Eurípedes paga a conta. Ajeita o chapéu na cabeça dela. Carinhosamente. Pega no colo. Sai da venda. Volta para casa. Pela última vez.

- Estava se despedindo de mim...

- E você, coitadinha, voltou tão feliz com aquele chapéu.

— Meu Deus! Será que naquele dia ele comprou também o... 
- Não... Acho que não... E ainda que fosse... Ninguém estranharia. Era muito comum ter o veneno em casa. Quase todo mundo tinha uma lata de formicida pra combater as formigas que maltratavam as plantações.

Com tantas lembranças recuperadas, ao longo dia do suicídio do Presidente do Brasil, a noite chegou e levou para a cama mais cedo avó e neta, cansadas e tristes.

\section{1}

Com a morte de Eurípedes, luto. Cotidiano modificado. A família formada apenas pelas três mulheres, gerações diferentes. Mudança de casa. Não apenas por causa das lembranças do fato marcante. Faltava dinheiro. Vó Mina levada pelos amigos para Goiandira. Temporada longa. Joana querendo sair. A menininha por conta "dos outros". A mãe impaciente. A menininha apanhando, às vezes, sem entender porque. Aconteceu quando brincava sozinha na frente da casa e de repente... "Luiiiise!" O grito veio de dentro. O tom de voz carregava disposição de bater. O medo cresceu. "Passa aqui agoora!" Fugir! Olhou para um lado para o outro. Pra onde? Do outro lado da rua, o capim seco do pasto batido. Atravessou. O "Volta aqui!", perto. Correu mais. "Fugir vai ser pior, sabe disso." Sabia a dor que iria sentir se pega. Correu mais ainda. "Para!" A ordem. As perninhas doendo no jeito de perna pedir: "Para!" O passarinho endoidando no peito: Para não! Para não! Para não!... A lembrança antecipando a dor... Ai! "Peguei! “Adiantou fugir? Toma! Toma!” Ai-ai-ai... “Toma!” "Avisei que seria pior se fugisse não avisei?" Toma essa e mais essa pra aprender a não fugir de surra! Ai-ai-ai... "Da próxima vez que eu chamar, vem logo apanhar e não fuja!" E lá foi menininha mandada 'chorar na cama que é lugar quente'. Cara inchada. Bumbum doído. Olhando pela janela viu um coelhinho de nuvem passar deslizando... Na imaginação, montou nele... Pairou acima de tudo... Distante do chão... Não podia mais ser alcançada. Acabou dormindo. Acordou e não lembrou mais que apanhara. 
O tempo veio. Joana conheceu Esteves. O respeitado empregado da charqueada, viúvo, honesto e trabalhador. Deu a ela estabilidade mesmo morando por muitos anos em casas separadas. "Ah, não." D. Lizandra não dividiria o lar e a responsabilidade de criar os netos, filhos do casamento do único filho e da falecida Zulmira, com uma mulher já carregada. "De jeito nenhum”. Na ocasião, Joana já tinha mais dois filhos: Pitida com quatro anos e Zé com três, frutos de relacionamentos eventuais não duradouros. Luise completara sete, idade de ir para a escola. "Externato Santo Antonio", dizia a mãe animada naquele primeiro dia de aula da filha... Separando o melhor vestido... "O de ver Deus". Supervisionando o banho... "Limpa bem essas orelhas". Dispensando especial cuidado com os cabelos... "Deixa lavar isso direito". Esmerando no penteado... "Cachinhos da Shirley Temple." Caprichando no arremate com a fita branca... "Fica quieta. Vou ajeitar o laço".

Levou a filha para a escola. Deixou aos cuidados da D. Ercília. Encaminhada ao pátio e lá deixada, a menina paralisada pelo espanto de ver tanta criança no mesmo lugar. Sem o uniforme, percebida logo. Cercada por duas meninas grandes. "Qual seu nome?" "Onde mora?" Sob o intenso interrogatório, viu surgir o bando de meninos em correria. Entre eles a meninona que titubeou ao vê-la e acabou parando. Começou a vir na sua direção. Calou as especuladoras. Caminhando devagar. Sem desviar nunca o olhar. Estacou na sua frente. Muda. Ofegante. Suada. Coçando a cabeça sem parar. Em dado momento, pareceu capturar qualquer coisa entre o polegar e o indicador. Esticou o braço por cima da cabeça da menina abriu os dedos e do alto soltou o que fosse sobre os cachinhos brilhando ao sol do meio dia. Naquele momento, o sininho brandiu. Alguém se encarregou de posicionar a novata na fila. O episódio perdido entre as novidades do dia.

Ao entrar na sala, Luise viu que a primeira professora dela não era outra senão a própria D. Ercília. A diretora lecionava ao mesmo tempo para as duas turmas extremas da sua escola: alfabetizava os que estavam chegando, formava os que estavam saindo. Reservando a primeira fileira de carteiras para os pequenos da cartilha, destinando as demais aos alunos da quarta série. Depois de fazer o 
primeiro ano atrasado na escolinha particular, Luise matriculada na Escola Paroquial São Bernardino de Siena.

Da pequena escola, o aprendizado das primeiras letras e duas lembranças indeléveis. Uma delas, consequência do gesto da meninona naquele primeiro dia de aula, se manifestou poucos dias depois na desmedida coceira que levou a mãe a examinar a cabeça da filha e constatar horrorizada... "Cheia de piolho!" Trouxe desdobramentos: os bastos cabelos tosados na barbearia com tentativas de consolo... "Ficou muito bonitinho!" "Mais fácil de cuidar". O cabelo curto gerou acontecimento inusitado. Aborrecida pelo corte a la homem e incomodada com os sapatos novos do uniforme apertando Luise saiu mancando da sapataria do Floro. Esperava a mãe do lado de fora e viu a mocinha que andava de braço dado a uma senhora apontar para ela... "Olha mãe!" ...arrastar a outra na sua direção. "Olha, só" Parada diante da menina, a mocinha não hesitou, levantou o queixo dela suavemente com a ponta do indicador e ficou examinando o rostinho sério. "O cabelo... Os olhos... Não é mesmo a cara dela, mãe?"

Luise espantada e sem entender nada. A mais velha concordou e com simpatia na voz perguntou para a menina:

— Qual é o seu nome?

Não era acostumada a ser objeto de admiração e respondeu lacônica.

- Luise.

— Sabe quem é a Marta Rocha, Luise?

Sabia. A fotografia e o nome estavam nas capas das revistas.

— Alguém já disse que você é muito parecida com ela?

Não habituada a receber elogios, baixou a cabeça. Não, ninguém dissera. Nem ela pensara. E naquela hora, lembrando a imagem que vira da Miss Brasil na capa da Manchete e d'O Cruzeiro, não conseguia achar a semelhança alegada. As mulheres paradas. Caras sorridentes. Olharam para ela mais algum tempo. Depois 
deram tchau e foram embora de braços dados. Antes de dobrarem a esquina, viraram para trás e acenaram mais uma vez para a menina, encabulada, parada no mesmo lugar, esperando pela mãe. Essa admiração toda... Vai ver que só conhecem a Marta Rocha de papel... Saem procurando a cara dela em todas de cabelo curto e olhos verdes... Bobeira!

A segunda coisa inesquecível do tempo da escolinha aconteceu num dia de aula qualquer. Alheada, caprichando no dever de caligrafia, Luise escutou de repente a voz da D. Ercília alteada. Levantou a cabeça e ficou paralisada vendo a professora sentada à mesa dela virar de costas e tirar o chicote pendurado num prego na parede atrás. Logo endireitou o corpo e começou a açoitar, diante da classe inteira, o aluno da série adiantada de pé na frente dela. Para tentar se defender das vergastadas, ele dava pulinhos de um lado para o outro e protegia o rosto com os braços logo alanhados pelos vergões, que cresciam grossos. Em dado momento, a professora se pôs de pé, o rapazinho se jogou no chão e escorregou por baixo da mesa dela. A mulher não desistiu. Abaixou-se. Bateu. Bateu. Bateu. Alguém apareceu, com a professora e o rapazinho no combate sem trégua. Ele, vermelho, rolando. Ela de olhos saltados, chicoteando. Os alunos tirados para fora da sala depressa. Luise levada para casa se perguntando... Como será que começou? Por que será que aconteceu?

43

Joana se acertou de vez com Esteves e foi morar perto dele na colônia da charqueada. Fileira de casinhas iguais construídas de um só lado da rua, frente voltada para o pasto, que ao longe se perdia. No dia em que foi fazer a limpeza para mudar, apontou para a construção grande e única à direita, dizendo para Luise:

— Lá é a charqueada onde o Esteves trabalha. 
— Eu sei, Mãe... vim com você aqui antes... lembra... A Tita foi lá em casa e a gente veio trazer ela de volta... Ainda bem que a pestinha mora na primeira casa da fileira e a gente vai mudar pra a última.

$\mathrm{Na}$ volta, Joana toma a direção contrária da casa onde Esteves mora.

— Tá vendo aquela estrada, Luise?

- Hã...

- Vai pra Goiandira.

Na esquina, a capelinha enfeitada de flores e velas erguida à esquerda é que chama a atenção da menina.

— Que igrejinha é aquela?

- É a Cruz do Antero.

- Antero... Que Antero?

Joana baixou o tom de voz.

- Um homem que mataram.

— Por quê?

- Não sei a história direito.

- O que foi que ele fez?

- Diz que praticou um crime.

- Crime? Ah, Mãe, conta do começo, vai.

- Chiii... Fala baixo!

“O caso é cheio de mistério. Ninguém gosta de falar nele. Aconteceu num tempo de muita violência por aqui. Época tumultuosa em que era comum um chefe político ter guarda-costas...”. Percebendo talvez que não podia escapar do assunto sem aumentar a curiosidade da filha, Joana resumiu como pôde quem era Antero da Costa Carvalho e o que tinha acontecido com o rapaz, quando ela mesma era apenas uma mocinha. 
"Um fazendeiro emboscado e morto. Na busca pelo culpado confusão e futrica. Parentes e amigos forçando a investigação. Um filho da vítima acusado de mandar matar o pai. Questões de herança. Fizeram tudo pra obrigar o moço a confessar. Ele não esmoreceu. O jagunço Chico Prateado preso como suspeito de ter sido o contratado. O nome do Antero apareceu como contratante. Amigo do morto a quem devia dinheiro e favores como tantos outros, Antero preso. Uma noite, um bando de homens invadiu a cadeia. Tirou ele de lá. Empurrou pelas ruas. Mataram quando caiu aqui e não conseguiu mais levantar. Tinha 31 anos de idade. Não era da cidade. Nasceu em Jataí. Mudou com pra cá por influência da mulher que conheceu em Campo Grande e tinha a família aqui. Antero era farmacêutico prático. Montou farmácia aqui mesmo no Bairro da Grota. Trabalhou no Cartório de Registro Civil. Ajudou a fundar um jornal. Diz que era muito gentil. O professor João Martins conta que admirava o bom tratamento que o escrevente dava pras pessoas, fazendo praticamente todo o serviço do cartório. Aos doze anos, trabalhando nas horas de folga da escola como mensageiro, indo ao correio, levando processos pro Juiz, pro Promotor, era sempre bem tratado e elogiado pelo escrevente nos dias de mais trabalho. Diz que Antero criava poesia e às vezes pedia pro mensageiro ler em tom declamatório: "o que fazia de bom grado, recebendo dele até palmas". Era estimulado pelo poeta a fazer poemas: “compor versos é como colher flores num jardim que a gente cuida bem.”.

Somente anos mais tarde tomando conhecimento aqui e ali de certos episódios, a filha compreenderia a reserva da mãe, nesse dia em que passou com ela pela "Cruz do Antero" e pode sentir seu desconforto ao perguntar sobre o poeta.

— Está enterrado aqui?

- No cemitério.

- Por que fizeram essa igrejinha pra ele?

- Muitos acreditam que era inocente... um mártir... que agora faz milagres.

"Na época do coronelismo, as pessoas mais influentes mantinham escoltas formadas por parentes, amigos e jagunços pra se protegerem.” Luise perplexa ao saber de um tempo em as pessoas mais importantes da região precisavam 
contratar proteção, fica por muito tempo assombrada por alguns nomes: Cabeleira. Caldeira. Negrão. Neca Mulato. Rigozino. Charuto. Chico Prateado... Evita imaginar como seriam as caras desses homens que ficaram conhecidos pela crueldade soprada pelo tempo, esticando a fama de cidade violenta.

No nascedouro da intriga, ingredientes de intrincada trama policial. O prestigioso Albino Felipe do Nascimento, fazendeiro de 78 anos de idade, segundas núpcias contraída com uma jovem, morto numa emboscada no lugar chamado Pedra Preta. Os amigos da vítima pressionando as autoridades legais a elucidar o caso. Quem matou o Albino? O aparato policial, tíbio. O judicial, para constar. $\mathrm{O}$ delegado na dança da ocasião. O prefeito se omitindo. $\mathrm{O}$ juiz de direito saindo de licença. Pistas distorcidas. Roteiros duvidosos. Ninguém disposto a falar sobre assunto com clareza. Perguntas sopradas. Respostas inconsistentes. Cipoal de especulações. João Albino era filho do primeiro matrimônio da vítima. Suspeito. Não aprovava o segundo casamento do pai com a moça mais nova. Acusado. Mandou matar o velho porque tava com a herança em risco. Preso. Não aceita a imputação pela morte do pai. Torturado. Apertaram arame farpado em volta da cabeça dele e enfiaram farpas de bambu debaixo das unhas. Preferia ser morto a confessar. Novas conjecturas sobre o mandante. A veia mandou matar por causa da fia. Preso o jagunço executor. Chico Prateado faz cobranças para o Antero. O coletor-poeta tinha permissão pra entrar e sair da fazenda à vontade. Compadre do fazendeiro duas vezes, amigo a ponto de emprestar dinheiro, devia ao falecido e a letra tava vencida, mandou matar pra ficar livre da dívida. Antero preso. Chico solto. Mandado embora montado numa mula 'pelo de rato', escoltado por outro jagunço até a beira do Paranaíba, recebeu um bornal de matula, cinco notas de 100 mil réis, uma carabina de oito tiros cheia de balas e o aviso: "Sai do Estado e não deixa rastro." A porta da cadeia encostada. Antero não fugiu. Dizia ser inocente e poder provar. 
16 de agosto de 1936. Oito horas da noite. Tropel de cavalos. Anos mais tarde, a mocinha Labiba contou que viu a turba passar no escuro e se lembrava bem. Primeira vez que ia ao cinema, atravessara a rua com o pai, a mãe, os irmãos. E como me lembro em cadeiras juntinhas, ocupando uma fileira do pioneiro cinema da D. Diva, assistíamos o filme com a garota prodígio Shirley Temple. Sentia-se emocionada e embevecida. Radiante, feliz, vibrava de emoções. Empolgava-me com a garota maravilhosa e como era graciosa e desenvolta; Santo Deus! De repente, papai assustado, fisionomia carregada ouve pálido, o que José Faim Fayad lhe sussurra no ouvido. Levanta-se apressado e dá a ordem de comando: 'Depressa, todos pra casa!' Ninguém contesta. Assustou-se com o pavor estampado nos olhos adultos. Movimento desusado em casa. Gente grande num vai e vem acelerado, silencioso, buscando armas, balas, carregando revólveres, carabinas e uma arma estranha. Metralhadora. Soube mais tarde. "Todos pro quarto". À ordem enérgica de papai, fomos todos para o dormitório, no andar superior. A Shirley Temple da tela era corajosa e eu a invejei, lembrome bem. Sorrateiramente, saí de gatinhas do quarto, às escuras, burlando a vigilância da irmã mais velha e escondi-me entre os pilares que contornam o alpendre, quase defronte o jardim. Lendo o que Labiba escrevera, Luise vai reconstituindo as cenas passadas no elegante Edifício Nars Faiad. A mocinha ajoelhada no piso frio, cara espremida entre dois pilares do alpendre, olhos esbugalhados, tremendo todinha, escutando o tropel da cavalaria vindo lentamente do lado de cima e ganhando forma. Vulto gordo, todo de preto, num cavalo branco... Vulto magro, todo de branco, num cavalo preto!? Pavor! Pavor! Noite escura. Tenebrosa. A cavalaria imensa quebrando a esquina, pertinho, levantando um muro de poeira. A mocinha colada na parede acompanhando o tropel sinistro seguindo pela Rua do Comércio na direção da prisão pública. Petrificada. Batendo queixo.

Naquela noite, a cadeia foi invadida. Antero arrastado e empurrado à ponta de faca pelas ruas passou pela porta do prefeito, que ouviu os pedidos de socorro, saiu ao alpendre e entrou de novo. Na encruzilhada, a criatura caiu pela última vez. Disse que precisava revelar um segredo. Pediu para chamar João Albino, o filho da vítima, primeiro acusado. O chefe do bando engrossou a voz. "Não tem segredo nenhum. Acabem logo com ele.” O punhal comprido desceu e varou o coração poeta. 
Não demorou muito: Antero era inocente. O poeta não matou o fazendeiro. É um mártir. Um santo. Tá fazendo milagre. Um dia há de ser canonizado. Se o Antero não era culpada por que matar o poeta? Quem foi? Quem mandou? Por que foi? Por que mandou? Perguntas espatifadas nas muralhas do mistério. Pulverizadas na nuvem de poeira das especulações.

A mudança para a colônia teve o seu lado bom. Ficava mais perto do campo. Nos belos dias de novembro Joana podia de repente convidar... "Vamos catar gabiroba?" Aceitação imediata. "Vamos!" Diversos timbres. Munida de balde e muita disposição, saía ela de casa e subia a rua, com os filhos. Passava pela Cruz do Antero, dobrava na direção de Goiandira e mais adiante pegava a linha do trem.

Um dia, Luise vê um abrigo de trapo se destacando no meio do mato e pergunta.

— Mãe, mora alguém naquela cabaninha?

- Algum morfédico.

- O que é morfédico?

- Pessoa que tem lepra. Leproso. Tem que viver isolado dos outros pra não passar a doença.

A menina ergue os olhos para o céu e vê as nuvens deslizando impassíveis... Deve ser horrível ser obrigado a viver separado de todo mundo.

$\mathrm{Na}$ altura do Córrego do Almoço e do Frigorífico, desviam para a esquerda, o aviso.

- Antes de pegar gabiroba, joguem uma pedrinha na touceira e andem em volta pra ter certeza de que não tem cobra debaixo dela. 
Pitida pergunta:

— Mãe, qual é mesmo a cobra que morde e não mata?

- Diz que existe cobra não venenosa, mas aqui tem mesmo é cascavel e todo o cuidado é pouco.

A filha insiste.

- Ah, deve ter alguma... Escutei a D. Lia falando que a barriga da Anja inchou daquele jeito porque ela saiu pra catar gabiroba e foi mordida por cobra.

A mãe virou o rosto enviesando o olhar e mal disfarçando o riso. Não precisou responder. Passando debaixo do arame farpado e entrando no campo, Pitida quis logo se aventurar.

— Olha o pé de mangaba... Carregadinho!

- Não precisa subir. O chão tá coalhado. Se quiser comer, é só pegar as não machucadas.

- Não gosto dessa fruta... leite enjoativo... Mãe, o Zé tá comendo matacavalo!

Joana corre para o filho.

— Diacho... A gente não pode nem piscar.

Abaixa a cabeça do menino e aperta suas bochechas.

- Cospe tudo fora, já! Cospe!

Ao adentrarem o mato mais um pouquinho, touceiras e touceiras ofertando gabirobas. "Cuidado com cobra!" Diante de cada pé carregado, o ritual de aproximação cumprido. "Nenhum bicho pra sair." As mãozinhas colhedeiras eficientes aliviando a moita das frutas maduras. Gabiroba para boca... Cloct! Gosto bom! Gabiroba para a boca... Huumm! Gabiroba para o balde... Gabiroba para a boca... Tarde à dentro. Companhia ao redor. Borboletas esvoaçando. 
Bichinhos zunindo. Passarinhos trinando. Sombra protetora das árvores tortuosas. Galhos parados. Arbustos empencados de flor. Ar parado. Folhas machucadas. Cascas pisadas. Mistura de cheiros. Umidade. O campo respira.

- Mãe, deve ter cobra, ali! Não tem vento nenhum e as folhas tão balançando muito.

- Calma!

- Chiii!

— Tô com medo... "Bamo" embora!

A galhada mexe no meio do mato.

— Ai-ai-ai... Né cobra não!

- Será alma?

O homem surge equilibrando um feixe gravetos na cabeça.

Ora, gente... É o Joaquim Lenheiro! Tarde, Joaquim.

- Tarde.

— Que lenha sequinha... Tá encomendada?

- Tá

— Quando puder, leva um feixe desses lá em casa.

- Certim.

- Até logo, Joaquim.

- Inté.

O Lenheiro torna a desaparecer no mato, balançando as trouxinhas amarradas em volta do corpo. "Nelas guarda todo o dinheiro que ganha da cata da lenha." Todos cansados, tomam o rumo de casa, satisfeitos. 
Morar perto do Esteves custava alto preço. Joana e as crianças tinham os passos controlados. Uma tarde, Luise viu o padrasto chegando e a mãe pegando o chicote... Pra quê? “ Luise, Pitida venham cá!" Schlept! Schelept! O couro começou a cantar nos pequenos lombos. Ai-ai-ai... As meninas não entendiam porque e procuravam argumentar. " A gente não fez nada, Mãe!" Schlept! Schlept! Tentavam proteger o rosto com as mãos. Os vergões cresciam ardidos nos braços levantados. " Para, Mãe... Ai-ai-ai... Para... "Tá batendo na gente por quê?" Ai-ai-ai..." Na luta para se esquivar, Luise viu o padrasto passar impassível para o quarto e registrar a cena. "Pra aprenderem a não mexer mais com D. Lizandra." Então era isso! O que será que a bruxa inventou dessa vez? Tanto tempo não vejo a cara dela. Não gosta de nós... Devíamos cortar sempre volta. Nunca passar pela porta dela! Três ou quatro dias atrás, voltamos da escola pela Rua de Baixo. Tava lá. Acocorada na porta, como de costume. Olhar longe. Parecia ver nada ou ninguém. Falei pra Pitida. "Parece um totem." Subimos a rua, rindo baixinho. Antes de entrar em casa, porque dei aquela olhadinha pra trás... como se puxada por uma força qualquer... Não sei. A velha tava lá embaixo pescoço esticado acompanhando a gente com olhar de vaca. Mostrei pra Pitida. Aí, sim rimos pra valer. Só isso. Nem lembrava mais. Aquela índia velha deve ter aumentado essa história ou inventado outra e o filho fez a gente pagar caro pela pouca diversão. Quando ele passou pro quarto e olhou pra gente apanhando entendi tudo... Ah, se o meu olhar fosse um fuzil... A Mãe esperou ele chegar e pegou o chicote. Não perguntou nada pra gente. Bateu sem saber direito por quê. Bateu pra ele ver. Coitada, da Mãe, ter que se sujeitar... Talvez tenha doído mais nela...

Muitas crianças têm padrastos, madrastas. Alguns maus... Como a Cinderela tinha... Preciso reler a história na minha revista "Contos de Fada." A Cinderela era obrigada fazer todo o serviço... Vestido velho... À beira do fogão... Sem poder ir ao baile... Chorava que nem eu agora... De repente, o bater de asas... A sombra passando ao lado... Olhou assustada e viu mulher de preto a sua frente... Segurando uma varinha... Vestindo uma capa larga... Usando chapéu alto igual de palhaço... Olhos brilhando que nem 
estrelas por baixo da aba... Disse pra Cinderela: "Vamos trabalhar? Se continuar aí sentada chorando, nunca poderá ir ao baile. Levanta e faça tudo o que eu mandar." A Cinderela perguntou quem ela era. "Sou sua fada madrinha."

Um dia, também posso encontrar a minha fada madrinha, fazer tudo que ela mandar e quem sabe vou até poder ir a um baile como a Cinderela.

Por essa e outras, talvez Joana tenha entendido que morar na colônia não dava certo. Convenceu Esteves. Mudou para a vizinha Rua da Grota, com a vantagem de continuar perto dele e ter um pouco mais privacidade. Dias melhores vieram. Para ela e os filhos. Uns crescendo e outros chegando. Na rua comprida de muitas crianças, logo nasceu Élcio. Luise fez as primeiras amizades. Marizé morava na casa da frente, Cecília, na primeira do lado esquerdo e Helena, nesse mesmo lado, três adiante. Todas mais ou menos com a mesma idade. Aproximação natural. Bons anos. Belas tardes. Brincadeiras. Durante o dia, no quintal, a casinha podia ser debaixo dos pés de milho ou em cima da árvore, com os galhos tornados quartos, cozinhas, salas de visitas, igrejas para batizarem bonecas e o que a imaginação mais aprouvesse. De tardezinha, as mães instaladas nas cadeiras dispostas em frente às casas, interagindo e presenciando os rebentos banhados, penteados, participando de brincadeiras variadas. 'Par ou ímpar?" "Se essa rua, se essa rua fosse minha..." "Vamos passear na floresta...." "Boca de forno, tirar um bolo..." Escurecia e a função prosseguia... Luz da lua. Estrelas salpicadas. Outras luzes...

Vagalum tum tum

seu pai daqui

sua mãe tá ali

tocando viola 
"Eu já peguei três!" "Pra ter uma boa lanterna precisa mais no vidro ". "Você tem quantos?" "O meu é pequeno e já tá cheiiinho!"

Época de aventuras memoráveis.

Luise incentiva Pitida a subir no pé de caju. "Os mais bonitos estão nas pontinhas dos galhos mais altos. Você é pequena, mais leve e vai chegar lá." Debaixo da árvore, orienta a irmã. "Desse lado, não tem mais nenhum. Pronto. Muda pro outro.” Pitida apontando um galho: “Esse?” "Não, o outro. Aquele lá... Tá vendo? Tá cheiiinho. Cajus maiores. Mais maduros.”

Embaixo, Luise procura o melhor ângulo. Mãos em concha. Apara as frutas que a irmã vai atirando.

— Vem mais pra ponta... Só mais um pouquinho... Isso!

A Pitida alcançou as grimpas. O galho... Crrrééé... Luise viu a casca se descolando... Crrrrééééé...e gritou para a irmã, sacolejada pelos arrancos:

- Segura firme!

Luise assiste sem poder fazer nada o galho partindo e rasgando a fibra externa do cajueiro... Crrrrrrrééééééé...Vindo abaixo lentamente e trazendo a Pitida agarrada como um papagaio no poleiro. Vendo a irmã chegar ao chão suavemente sem um arranhão, a menina não se contém diante dos olhos de jabuticabas espantadas.

— Pitida, demaaais, Pitida...! Como se você tivesse pilotando um avião... Um teco-teco, Pitida! 
O que podia ter sido uma queda feia não passou de um pouso bem sucedido, amortecido pela frondosidade.

49

Outro dia, a certeza de que devia plantar um pouco daquele milho de pipoca tão bom, fez Luise pegar o enxadão e tentar abrir as covinhas. A menina chamou Pitida para jogar dentro delas os grãos escolhidos das espiguitas mais sadias. Terreno seco. Difícil de ser rompido. A ferramenta resvalando no cascalho. Luise insistindo, incentivada pela irmã, sempre perto. Perto demais. Golpeada no pé, de repente, Pitida teve a unha do dedão rachada, semeando, involuntariamenteos os pingos dourados que tinha nas mãos, a torto e a direito, Luise vê os grãos caindo, no chão encharcado. Será que o milho vai nascer vermelho?

— Foi sem querer, Pitida, sem querer...

Luise não escapou da saraivada de acusações.

— Rachou minha unha com o enxadão.

Pediu desculpas.

Pouco adiantou. Pitida não perdia chance de choramingar e jogar na cara dela o tempo todo: "Você rachou a minha unha com o enxadão."

Luise crescia e aprendia que a vida vai sendo tecida com os sucessos e os insucessos do dia a dia. 
Fim de temporada. As frutas no alto pareciam as mais gostosas. Última penca. Dourada. Desafiando a coragem de quem quisesse se arriscar. Olhando para elas, Luise pergunta:

— Dá pra tirar?

Helena levantou a vista e avaliou.

— Não, com aquela guarda. A caixa tá muito perto.

Cobiçaram. Desistiram. No dia seguinte, de novo debaixo do pé, pescoços espichados.

- Amarelinhas.

- Suculentas.

- Não adianta ficar aqui olhando sem poder fazer nada.

- Vamos pegar goiabas.

Mal começaram a caminhar para a goiabeira... "Heleena... As 'golhabas tão verdes. Não vá tirar! Verde e azeda é essa D. Quetita. Não perde nada. Mesmo de longe, o grito de maitaca resfriada alcança a gente. "Tchau, Helena!"

Luise tomou o rumo do quintal da própria casa. A mente ocupada de novo com as frutas maduras. Para ela, questão de tempo por as mãos nas gostosuras.

No outro dia, volta sozinha. Espia o objeto da cobiça. Arriscado? Era. Reconhecia a espécie pelo tamanho e cor. Não à toa a mais temida. Unzinho pode acabar com a alegria... A esquadrilha toda causar estrago enorme! Decisão tomada. Hora de agir. Não mais de pensar. Plano pronto. Repassa. Subo até aquele galho. Na bifurcação, braço esquerdo segurando o tronco. Pés firmes. Pescoço reto. Sem poder ver a penca, mas sabendo que tá logo acima da minha cabeça. Levanto o braço direito devagarzinho. Toque leve da mão. Todas caem de madura. Sem os intrusos perceberem. Desço e me delicio com as gostosuras. 
Subir na velha árvore alta não é problema para a menina, acostumada. Todo o cuidado é pouco com os invasores nela instalados. Um, dois, três... já! Começa escalada para valer. Arrasta-se até o limite máximo de segurança. Faz a pausa planejada. Tudo certo. Dali em diante, real perigo. Qualquer erro, ferrada. Cola o corpo ao velho tronco. Endurece o pescoço. Controla o tremor nos joelhos. Mal respira. Ergue braço len-ta-men-te, mão espalmada. Testemunha prestando juramento. Hora do impulso final. Prende a respiração de vez... Zaz! Brbrbr... Brbrbr... Hã!? Não contara com o barulhão da penca indo abaixo... Brbrbr... e agora... Bzzzzzzzzzzzz... Aiaiaiaiai... "Bzzzzzzzzzzz... Socooorro! Bzzzzzzzzzzz. Meu Deeeeeus! Bzzzzzzzzzz... Aiiiiiiiiiiii...é ferozmente atacada. Atordoada pela dor das mil picadas. Sem saber como chegou ao chão sem cair. Atravessou os quintais aos gritos e às carreiras. Acudida pela mãe. Esfregou álcool no seu corpo ardido... Ai-ai-ai... Arrancou... um... Ai! ...por um... Ai! ...os mil ferrões encravados com a pinça de sobrancelhas. Viu sua cabeleira entranhada de cadáveres de marimbondos, rosto, braços e pernas, deformados pelo inchaço.

Das mangas cobiçadas... nem cor e nem cheiro... Quem comeu quieto se regalou... A Dona Quetita... Será?

Sentada no degrau da porta da cozinha com uma caneca de café preto do lado e um pedaço de pão nas mãos, Luise se distrai com as galinhas ciscando as migalhas que vai jogando no chão. Acha graça da valentia da garnizé rodeada pelos dez garnizezinhos, piando em volta. É mãe zelosa e orgulhosa. Ai do que queira se aproximar... arrepia furiosa, pronta pra avançar e bicar. A menina acaba de fazer a repartição do pão, bebe o resto do café e pega a Tuta no colo. As galinhas da mãe tão bem gordas... O canteiro de salsa viçoso e verdinho no ponto de ser usado na sopa do resguardo. É só isso que as mulheres comem na primeira semana. O Zé com o problema que tem... O Elcio com um aninho só... Ela já vai ter outro nenê... Em pouco tempo essas frangas todas vão parar na panela. A cada dia, uma vai ser morta, depenada, sapecada, 
picada, cozinhada até ficar bem macia e com o bom caldo grosso de escaldar a farinha de milho, muita salsa picada, na tigela de louça, reservada só pra isso. Tem que estar sadia e sem gogo... Eca! Só de pensar naquela caroceira em volta dos olhos delas... Que nojo! Galinha crescida e engordada no quintal garante a sopa do resguardo... Diz que melhora o leite.

- Oi, Luise.

A menina reconhece a voz da enteada da mãe, abaixa a cabeça e enfia a cara nas penas macias da Tuta.

— Ei! Ei! Não vai responder por quê? Sunga essa cabeça daí. Tá de veneta,hoje, tá?

Sem resposta, a Tita volta para a cozinha. Luise liberta a galinha de estimação. Embrenha-se no quintal... Anda por aqui... Por ali... Demora examinando as flores da laranjeira, de perto... Delicadeza. Passa bom tempo, distraída. Volta ao terreiro. Escuta risaiada abafada! Entra na cozinha. Pitida em cima do tamborete colocado sobre a mesa espia a casa dos vizinhos pelo vão no alto da parede-meia. Tita segura as pernas do banco, riso escancarado. Acenando e chamando Luise para ver. Pelas caras das duas devia ser uma coisa muito engraçada. A menina curiosa. Concorda. Pitida desce apertando a boca com as mãos, tentando prender o riso. Luise sobe na mesa... No banquinho... Olha pela abertura no alto da parede... Petrifica-se. Não pode acreditar no que vê. Pela porta do quarto, largamente aberta, o casal inteiramente nu, sobre a cama desfeita. Deitados de lado, parecem dormir. Ela virada para a parede. Ele oferecendo vista ampla do membro ereto... Quase do tamanho de um cavalo urinando no pasto! Parece dentro de algum pesadelo! Quer escapar dali. Naquele momento, o barulho da mãe saindo do quarto, onde estivera ninando o nenê, arranca a menina do estado de 'paradinha aí estátua'. Desce depressa. Tira o tamborete da mesa.

Trabalho vão. Mal pode acreditar vendo a Tita indo ao encontro dela contar tudo, entre risos e cochichos. Se fosse a gente, aposto que não acharia tanta graça. 
Ao dar à luz outra vez, Joana teve complicações no parto. Passou o mês do resguardo, continuou acamada. Quando conseguiu se por de pé, o lado esquerdo esquecido. Mancava. O médico receitou Yodex. Pomada preta transparente e mal cheirosa, friccionada diariamente no corpo. Potes e potes. Inutilmente. Outros recursos... Rezas. Benzeduras. Raizadas. Sem resultado. Conformismo. Os filhos não escutaram lamentos. Mesmo sem andar perfeitamente, Joana mantinha jovialidade e humor brincalhão. Continuou com a capacidade de rir e aprontar das suas: "Luise, vem cá, espiar." A menina olha pela fresta da janela, e vê o Molafaca descendo a rua. "Presta atenção.", diz mãe, colocando dois dedos entre os lábios e zunindo assobio de doer nos ouvidos. A menina vê o acesso do homem lá fora. Grita. Pula. Parece que vai morrer de raiva. "Fica aqui", a mãe insiste. Dali a pouco, a filha mal pode acreditar... A Mãe saiu lá fora, perto do Molafaca?! "Ara, Bastião, mas o que é isso... Não fica assim, não. Deixa esse povo pra lá. Vem cá dentro. Vou te dar um café. Acabei de fritar uns biscoitos de polvilho. Vem." O homem entra com ela. Luise vai até a cozinha. Para à distância. Difícil acreditar que a pessoa sentada, de papo com a mãe, mansinha como um cordeiro, era a mesma que, ainda há pouco, na rua, pulava, xingava e babava.

Joana cuida muito bem do seu nenê e vai retomando vida normal. Tendo filhos, inclusive. Veio a ter Elenzinha e Dilson. Fora abortos.

Luise entra na casa da D. Quetita, com a importante missão de reaproximar Helena e Marizé. Por uma bobagem qualquer, trocaram o 'belém-belém nunca mais fico de bem', e não se falam há dias.

— D. Quetita, eu queria falar com a Helena? 
— Ela tá ninando a Sandra... Precisa passar a "salha" do uniforme, pra amanhã... Bla-bla-bla... Se quiser esperar.

A menina está acostumada e não se importa com o jeitão da mulher. Depois de responder, dá as costas e volta a preparar sua janta. Movimentos rápidos. Nas orelhas dela dois arrozinhos de ouro voando de um lado pro outro parecendo loucos para escapar. Esses brincos da D. Quetita deixam a gente meio hipnotizada... A Helena tem par igualzinho. A Sandrinha mal nasceu e também já balança seus dois grãoszinhos. Vai gostar assim desse tipo de brinco! Luise vê a mulher descascar os ovos cozidos duros... Partir ao meio... Mergulhar num refogado de cebola e cheiro verde... Não gosto muito de ovo. Mas esse molho dela... Huumm...é de dar água na boca. Se quisesse oferecer uma provinha... Acho até que aceitaria. D.Quetita tira a panela do fogo, sacode e tapa. Por que será que a Dona Quetita é azeda assim... Cara feia... Não acha graça de nada... Levanta cedo. Não para quieta. Lufa-lufa até a hora de voltar pra a cama de novo.

Aqui, as mães trabalham muito. Todas. Varrem. Limpam. Lavam. Cozinham. A minha nem tanto... Vovó ajuda muito. Quando tá em casa, tudo é mais farto... Tem sempre alguma coisa diferente pra gente comer... Um biscoito fresco... O 'bolo-de-pobre' dela, que não leva ovo, porque não come... Bolinho-frito no café da manhã... Doce de gergelim na sobremesa... Ela sabe fazer muita coisa. E não é só comida, não. Antes de ontem, cheguei da escola e por pouco não atolei o pé num dos pingados grandes espalhados no chão da cozinha, em cima do lençol velho esticado. Parecia até que alguma vaca tinha andado dentro da casa por um bom tempo. Se não tivesse me alertado logo que tinha feito sabão de decoada... Ai-ai! Dividira em porções e esperava amornar para enrolar em bolas. Mesmo fazendo tanta coisa, a Vó tira seu tempinho para visitar amigas, ir à igreja...

A D. Quetita não sai de casa... Não põe a cadeira na calçada... Mal cumprimenta os vizinhos... Não é capaz de fazer um aceno... Dar um sorriso... Dizer uma palavrinha... Nem mesmo pra gente, que mora do lado e tem a divisa dos quintais sem muro, sem cerca, nem nada. $E$ para piorar, a mania que tem de trocar as letras das palavras... Deve achar chic falar "salha", "golhaba", "samambalha." Ninguém corrige. Nem os filhos. O Tonho, formado... O Benício, estudado... Trabalhando fora e tudo... 
- Boa tarde!

— Tarde, Sr. Torrão. Tchau, D. Quetita. Falo com a Helena, depois.

Na rua, Luise encontra Pitida, saindo da venda do Sr. Zé Alvarino com um saco de pão.

— Que cara é essa, Luise?

— Esse Sr. Torrão é muito esquisito.

- Ele é bonzinho.

—É estranho, isso sim. Agora mesmo, fez questão de me seguir até a porta e dizer: "As filhas da Joana ficam cada dia mais parecidas com a mãe. Sabia que sua mãe foi uma das moças mais bonitas daqui?" Dentão de ouro... Botas de cano alto... Calça larga cor de terra...

- Usa calça larga porque é rendido.

— Rendido... O que é isso... Rendido?

- Coisa de cachumba que desceu... Sei lá. Outro dia, a Mãe e a D. Maria cochicharam isso, com ele passando.

Da janela, Luise vê o redemoinho... dança de um lado pro outro... arrasta tudo no caminho... poeira, folha, graveto... rodopiando... Aquele pedaço de papel de seda azul, aqui ainda agorinha... voa alto que nem pipa... Lá vai uma pena da Tuta... Ah, a Tuta... Às vezes, tudo parece calmo na vida, surge um desses corrupios pra bagunçar tudo! Ah, a Tuta... ganhada da boa amiga Cecília... "Vem brincar, vem!" Zelosa... "Já fez seu dever?" Companheira... "Descobri ninho novo da Carijó, vamos!" Generosa... "Quando nascer pintinho, vou dar um pra você." De palavra... "Pode escolher". Ela era assim. As coisas pareciam certinhas... a vida tava boa.. apareceu o túnel... Lembro que a Vó tava viajando, a Mãe tinha saído... 
Cenas do curto passado esboçam o desenho de certa tarde. A menina em casa estudando sozinha, interrompida. Choro? Rua de muitas crianças. Choradeira parte da vida. Só na casa ao lado, Cecília, dez anos, duas irmãs mocinhas e dois irmãos menores... Lá, tem alguém apanhando. O lamento contínuo atrapalhava a tarefa. Quebrava a concentração. Ela começou a cantarolar baixinho. Fazia isso sempre que sentia medo ou precisava superar obstáculo. Daquela vez, a cantigazinha não tinha força para rechaçar o invasor. Começou a mordiscar o lápis. Serrinhas dos dentes entrando e saindo da madeira macia. Nervosamente. A tinta exterior cada vez mais estalada. O lápis salpicado de marquinhas. Sentiu incômodo já conhecido. O peso pressionou o pequeno peito. Antecipou-se ao grito aterrorizado-aterrorizante. "A minha mãe..." A menina estremeceu. De pé, num salto. Deixando o lápis cair e rolar pelo no chão. No ato de afastar a cadeira, escutou repetir... "A minha mãe está mo..." Voou porta afora. Ganhou a rua. Entrou na casa vizinha. Passou pela sala. Alcançou a cozinha. Lá, os dois pequeninos sentados no chão choramingando sozinhos. Quis parar. Titubeou. Seguiu, instada pelo pranto maior. Encontrou Cecília estacada no meio do quarto dos pais. Debulhava lágrimas. Chegou perto. Seguiu o olhar da amiguinha fixado numa direção. Na cama à meia distância a mãe dela gemendo e se debatendo branca como o lençol que lhe cobria as pernas.

A visão do quadro pareceu tocar num índice incrustado na própria carne da menina. Despertar nela uma espécie solidariedade essencial, básica, primária. O tempo parou. O espaço transformou-se em bolha do sentir. Segurou a mão da amiguinha. Sem poder dizer nada. Palavras não cabiam. Na gravidade da hora, tentativa de expressão verbal soaria tosca e seria falha. A mulher aquietou-se. No silêncio, só o choro de Cecília. Murmúrio de riachinho...

A vizinha entrou apressada, atraída talvez pelos gritos que pouco antes dali se ouvia. Decerto viera ajudar. Chegou tarde. Na quietude do leito desarranjado, restava o corpo abandonado. O acontecimento maior... Aquele... Tinha ocorrido, diante apenas das duas pequenas testemunhas de mãos dadas. A mulher começou a mexer aqui... ali... Aborrecida... Zangada... Por quê? Encarava a inexorabilidade do Mistério? Lamentava a própria tardança que a impedira de atuar no evento principal e sobrara a mera coadjuvação... Quem poderia saber? Nem a própria, talvez. 
$\mathrm{O}$ isolamento rompido. Luise premida pela necessidade de dizer alguma coisa. Falar para Cecília o quê? Perguntar pelas irmãs dela? O nó na garganta impedia. A precisão cresceu imperiosa. Empurrou a frase... "Não chora não, Cecília." Era mais comum de ser ouvida por qualquer criança saindo de uma tunda. Mas a maneira de dizer... Ah, essa foi diferente. As quatro palavrinhas deslizaram pela frincha entre o nó e a garganta trazidas pelo fio de voz no seu tom mais fraquinho.

A resposta veio rápida como uma pedrada. "Deixa a menina chorar!" Luise não revidou. Manteve-se nos limites dos direitos das crianças, entre os quais não estava incluído o de responder aos mais velhos. Não replicou, mas também não arredou pé. Permaneceu ao lado de Cecília, o quanto pôde. Não podia imaginar que a amiguinha ainda iria perder mais.

Antes da missa de sétimo dia, o viúvo começou a distribuição dos filhos. A vizinhança batia a língua nos dentes. "Carregou os pequeninos pra longe." O homem não dava satisfação. "Desaforo! Ele já devia estar 'arrumado." Cochichos teciam a indignação. "Viu como as duas mocinhas foram disputadas?" Luise foi procurar Cecília. "Levada embora, também... criada por gente estranha... pobrezinha", a inconformada parteira lamentava.

De hora para outra, Cecília sem mãe, irmãs e irmãos. Por último, ela mesma sorrateiramente pilhada da casinha onde nascera. Luise não soube mais dos dois pequeninos. Passou uma vez pelas irmãs mocinhas na rua, despidas da espontaneidade natural. Caminhando duras, caladas e sérias, debaixo do olhar severo da matrona adotante. Elas me viram e não disseram nada, como se não me conhecessem. Luise recebe às vezes a visita de uma figurinha, vestido singelo, estampa miudinha e costuma perguntar... Aonde andará você, Cecília?

Depois de aprender que se alguém perde alguma coisa ganha outra no lugar, a menina gosta de pensar em Cecília numa boa escola, brinquedos, vestidos, sapatos, roda de amigos que cantam pra ela... "Ó meninazinha, entra nessa roda e dançará sozinha e dançará sozinha." ...e ela responde: "Sozinha eu não danço nem ei de dançar porque tenho...” Escolhendo entre os companheirinhos novos “...alguém para ser meu par". Cecília levava jeito pra dança. Talvez queira aprender a sério. Quem sabe, vai ser bailarina famosa... Dançar num teatro maravilhoso... Aplaudida por muita gente... Até no estrangeiro... Tudo pode ser. Por que não? A vida tá sempre armando corrupios... Mudando as 
coisas... A Cecília... A Tuta... Ai! Luise lembra que escolheu o pintinho diferente, escurinho... Cresceu galinha, bonita como a Carijó... Não. A Tuta era mais bonita ainda do que a mãe dela. Criada na mão. A mansidão foi o mal. Um caminhão... Meu Deus... Um caminhão daquele tamanho... Mansa... Boba... A Tuta não fugiu. Foi esbarrada. E depois... depois... Alguém pegou o magote de penas ainda palpitando vida.... "Não está muito machucada, dá para aproveitar a carne." Levou pra cozinha. "O melhor pedaço é pra Luise. Comida na frente. Era a galinha de estimação dela." Reagiu. As lágrimas rebentaram... pingaram no prato... raleando o molho de açafrão. Elcio viu aquilo e entornou a água do próprio copo no seu pratinho. Virou mania. Era só se ver livre da vigilância e o menino... Zuque! Redemoinho leva muita coisa... Cecília... Tuta... Agora mesmo tá vindo um pra carregar a gente. A Mãe achou a casa que tava procurando. Em breve, vamos mudar daqui.

Na Rua das Sete Casas, o fato se dá. Não a meia-noite nem de madrugada, como os entendidos costumam dizer, acontece. Dia belo. Ensolarado. Na quietude de uma tarde de verão. Pouco depois da família se mudar. Vó Mina e a filha conversando na sala. Recortavam flores e bicos no papel manilha novo para forrar a prateleira. Os pequenos dormem. Pitida na escola. Luise já voltou. Sentada na cadeirinha encostada na parede da cozinha, diante porta, ampla vista. O quintal coberto pelos pés de abóbora viçosos alastrando livremente pelo chão. Do lado direito, a goiabeira solteira emprestando sua generosa sombra ao tanque de lavar roupas, junto ao muro. De repente, monotonia quebrada. A figura aparece no fundo. Movimenta-se. A menina não consegue parar de olhar para ela, vindo muito lentamente na sua direção. Não usa o lugar destinado à passagem: o caminho que parte do último degrau da escadaria da porta da cozinha e segue cortando a plantação até esbarrar no muro. Não vem caminhando. Vem com os pés pairando no ar. Passando por cima das aboboreiras, não toca uma folha sequer. Vem... Vem... Vem... Chega perto dos degraus... Eleva-se sobre a 
escadinha. Para na porta da cozinha. Flutuando. A pouca distância. Olhando diretamente para menina, pergunta... [Quer vir com o titio? O lugar é muito bom.]

— A Mãe não deixa.

— Luise, com quem tá conversando?

- Com o Tio Eurípedes.

A resposta dada com a maior serenidade. $\mathrm{Na}$ sala confusão cadeiras arrastadas, tesoura caindo, sobra de interjeições. Na cozinha, a imagem se desvanece no ar. A menina é logo cercada e crivada de perguntas. A mãe e a avó aflitas querendo saber tudo. Luise é obrigada a repetir muitas vezes o pouco que acontecera ali. "Ela deve ter cochilado." "Não é de dormir de dia.". Lá fora, a mesma tarde dourada e a quietude de antes. Apenas uma diferença, agora. Uma borboleta azul adejando suavemente sobre as flores amarelas.

No ar parado, o espectro da luz intensa do dia, decomposta pelos grãos de poeira suspensa, assemelha-se a uma nuvem porosa, pairando sobre os telhados e tremulando cores do arco-íris.

\footnotetext{
Galopa, Joaquim, que o gado estoura por esse Goiás afora!...

Enterra a espora!..."

Que sol!... Que poeira! ${ }^{10}$
}

O som do berrante que, a três quilômetros de distância, já podia ser escutado, calou. A batida surda dos cascos, cresceu. "Lá vem gado!" Portas e janelas, disputadas. A rua logo sendo tomada pela enchente branca nelore,

\footnotetext{
${ }^{10}$ Trecho do poema “Boiada”, Magma, João Guimarães Rosa.
} 
malhada, castanha, preta... Baba escorrendo, barbela oscilando, requebro de gebas, focinho investindo, chifre atacando...

Vaca subjugada, novilho tangido, marruá indócil... Ferida à mostra, cansaço, fome, sede... "É melhor pra limpar." O destino? A charqueada. "É rápido.” Luise escuta o padrasto contar o novo jeito de fazer a matança. "Forçam o gado a caminhar por um corredor estreito, na direção de uma espécie de cela, onde só cabe uma rês de cada vez".

Esgares, volteios, no desfile dos condenados... "Lá, a marreta desce, acerta a cabeça do animal." Fila vagarosa... "Vai parar tonto nas mãos dos carneadores" Saberiam? "O resto é igual." A faca carneadora... O gancho... O sal... O tanque d'água... O varal... "Já vi homens duros e brabos desmoronados, com os bezerros arrancados da barriga da mãe".

$\mathrm{Na}$ manhã seguinte, a carne chega em casa fresca. Lombos compridos, balançando na garupa da bicicleta do padrasto quase arrastando no chão. Na cabeça da menina, uma baba grossa suspensa...um olhar tristonho...uma ferida...uma investida...um marruá resistindo... As reses não podiam fugir do destino. Os peões faziam bem o trabalho deles. Na vez que fora, com a Lélia e a Nívea, buscar mangas no sítio do Naco... Lá tinha todas as qualidades: bourbom, sapatinho, coquinho, coração de boi, redonda, branca... ...estavam voltando, para casa, carregadas e na altura do CRAC, a pequena manada apareceu, guiada por dois vaqueiros. Por que a vaca me escolheu? Eu não vestia vermelho... Será porque, eu estava me movimentando de um lado para o outro? Percebeu medo? Olhando diretamente, investiu. 'Corra, Luise, corra!' Atendendo o comando da cabeça, disparou pelo campo aberto, que se alongava atrás do muro do estádio e... Correu... Correu... Correu... Até ficar sem saída e o coração vir à boca, quando viu a bocarra da grota funda aberta aos seus pés. Estacou. Virou. Lá atrás, viu a vaca quietinha, sob controle, e os vaqueiros, morrendo de rir. Voltou devagar e sem graça. Ficou algum tempo, meio ressentida com as amigas, também se divertindo à custa dela. Viu risos mal disfarçados nas bocas, escapando pelos olhos delas. Agora não importa. Gosto de pensar que, pelo menos, aquele gado, não foi sacrificado. No couro da vaquinha esperta, vi a marca do ferro em brasa, identificando a origem. A manada pertencia à fazenda Bela Vista. Era de leite e não de corte. 
No dia de finados Luise é levada ao cemitério pela primeira vez. Caminha entre a mãe e avó. Mãos dadas. Somam forças. Vó Mina desde que saiu de casa mal abre a boca. Próximo ao portão, a mãe aponta para a árvore de galhos longos, delgados e flexíveis, junto ao muro. "Aquela que eu te falei, Luise... Quando sacode os ramos, parece mesmo que chora... Como o povo diz. Agora, não vai dar pra ver." A menina vê a imobilidade da árvore. Talvez, dando tempo pros parentes chorar os próprios mortos. Dentro da cidadezinha murada, ela observa comportamento reverente. Sussurros... Suspiros... Soluços... E o som que mais sobressai... As passadas dos caminhantes. A mãe aproxima a cabeça e cochicha no ouvido da filha. "Antigamente, a Banda de Música ficava aqui no cemitério no dia de finados... Tocando sem parar... Pela manhã e depois das quatro horas da tarde até escurecer. A cidade inteira escutava e quase morria de saudade e tristeza." Luise anda observando as construções, espantada. Não esperava ver no campo dos mortos moradias tão variadas... Casinhas... Capelas... Anjos... Frases escritas... Enfeites... Campas simples de mármore... Ou mesmo... Só um monturo de terra. Vendo que a maioria traz escrito o nome do ocupante e duas datas, pergunta baixinho para a mãe o significado delas. Joana explica. "É o espaço de tempo que a pessoa viveu". A cova do Tio é das mais singelas. Apenas a cruz de madeira tosca, com o nome dele escrito em letra de caligrafia a identifica. Luise vê que a arvorezinha do lado está empencada de flores amarelas. Mesmo não sendo os girassóis amados, é companhia silenciosa e bela. As três mulheres ficam lá paradas por um tempo. Desorientadas. Como todos os que estavam ali. Sem compreender nada do Mistério. Ofertam o que podem. Pensamentos. Respeito. Saudade. Tristeza. Os passos em volta, por algum tempo. A impotência pesa. "Vamos?" Caminham de volta, depois que "despendem." Vó Mina sem dar uma palavra. A mãe mostra a campa do Antero. Simples. Apenas uma laje de cimento liso. Àquela hora já bastante enfeitada de flores e velas. Não precisa mais. De que adianta muita coisa... Se embaixo da terra é tudo igual... Caveira... Esqueleto branco, entupido de terra. Ao saírem pelo portão, Joana dá o aviso... "A primeira coisa a fazer em casa é lavar as mãos pra tirar qualquer terra de cemitério." O vento começa a soprar. Luise olha para as pontas dos ramos mais 
altos da casuarina, começando a se agitar. Descendo a rua, vê quase encostado no muro do CRAC o tronco grosso, esbranquiçado e espinhoso da barriguda sem flor... Pelada, ou vestida de rosa, essa árvore não combina com o lugar.

Os dias insistem em vestir a cor anil. O sol oferta rendas douradas. Tardes de calor intenso. A quentura deixa o ar abafado. Dentro de casa. Debaixo das árvores. Qualquer lugar.

— Luise, dá um banho nos meninos.

— Pode ser com água fria, Mãe?

- Não. Morna. O Elcio tá com um defluxo brabo. Vou levar pra Dinda benzer. Fazer um chazinho de poejo com banha de galinha e dar a ele de noite. Senão melhorar, levo ao médico amanhã.

A mãe não disfarça a cuspida para o lado. Cara de perrengue... Cuspe... Não é só o calor que tá incomodando a Mãe não. É enjoo também. Vai ter outro nenê. Daqui a pouco, tudo de novo... Frangas encomendadas... Canteiro de salsa... Tigela nova... A menina não tem altura para alcançar o fogão. Servese de um banquinho para subir e descer com uma vasilha baldeando água para o caldeirão de ferro em cima da trempe. Até uma lata de óleo vazia pode ter boa serventia, se tem alguém como Sr. Gercino pra dar um jeito nela. Soldou alça nessa aqui e fez caneca pra gente. As pessoas juntam latinhas de massa de tomate, levam pra ele colocar asas e usam pra tomar café. Quando a nossa bacia de banho furou, ele consertou e disse que ainda vai durar anos. Explicou que já recuperou piores, soldando fundo novo nelas. O Sr. Gercino é muito jeitoso. Ganha a vida com as próprias mãos. Sabe inventar. Aproveitar. Criou um jeito de fazer sandálias fortes, usando pneu velho para os solados e sobras de couro do curtume pras tiras. Além disso, toca sanfona que é uma beleza!

A menina acaba de encher a panela, mexe na lenha, atiça o fogo e vai para o quarto separar as roupas dos irmãos. Volta. Água no ponto. Outras tantas subidas 
e descidas do banquinho baldeando da panela para a bacia no chão. Depois sai vai buscar os irmãos. Ruiz é logo encontrado. Do lado de fora, sentadinho à sombra da casa, triscando bolinhas de gude e prestando atenção ao som.

\section{— Cadê o Elcio?}

Pitida tem um pedaço de linha saindo da boca e responde apontando para o lado da casa.

— Ainda não arrancou esse dente, Pitida? Dá logo um puxão, que sai de vez.

Luise rodeia a casa e escuta o outro irmão. "Cala a boca já morreu, quem manda nessa boca sou eu." Debaixo do sol escaldante, nariz escorrendo, travando guerra de mamona com a meninada.

— Elcio... Vem tomar banho!

— Já vou... Deixa só...

— Vem logo, senão a água vai esfriar.

O menino resiste. Traça um risco com o pé no chão. " Pisa nesse risco se "ocê" é homem... Pisa!" Quer sustentar a briga. Luise pega menino pela mão e leva quase arrastado.

— Pra dentro, agora. O sol tá estalando. Você também Ruiz... Vamos.

Pitida já arrancou o dente. Toma distância para jogá-lo em cima do telhado. Todos param para ver a pontaria dela. "Moeirão, moeirão, leva esse dente podre e me traz um são". Duas ou três tentativas, ela se livra dele.

$\mathrm{Na}$ bacia, despidos, os dois irmãos separados apenas por um ano de idade, parecem opostos um do outro. Ruiz, muito moreninho, cabelos e olhos escuros, duas amêndoas sombreadas por longas pestanas. O povo diz: "Um indiozinho Goiá." O Élcio, louríssimo, olhos azuis, cabelo espiga de milho e pele de leite. As pessoas falam: "Um querubim". A diferença não é só física. Ruiz é um intelectivo 
de Atenas e Elcio um guerreiro de Esparta. A pequena diferença de idade faz pesar o antagonismo.

— Ruiz, "ocê" não é filho da mãe não. Ela só tá te criando. Quando "ocê" era bem pequenininho, uma D. Preta passou e te deixou na porta de casa.

As duas membranas ciliadas borboleteiam levemente, no movimento de descida. Velam o brilho amendoado do serzinho perdendo a espontaneidade e se refugiando na introspecção misteriosa revelada no semblante sério. Ao perceber que podia irritar o irmão com a comparação plantada decerto por algum adulto inconsequente bancando o engraçadinho, Élcio, na inexperiência, não perde a oportunidade de atormentar outro e mais se diverte, quando há reação.

— Não! Não! Não! Ela é minha mãe sim... Para Zau! Seo bobo...

— Não vê como a Mãe é branquinha? A sua outra mãe é igualzinha a Maria Preta, do João Preto... Uma tiziu!

— Não. Não.

Luise ensaboa os meninos, pensando na pobre Maria Preta que passa os dias esfregando, lavando, escovando calças e paletós pesados. Coitada da Maria! A lavadeira gasta a força de mulher à beira do tanque da Tinturaria do Osmar, lavando a roupa suja dos outros para sustentar honestamente a si e ao filho, João. Além do exemplo do trabalho, lega também ao menino de doze anos, o sobrenome-apelido que carrega por causa da cor da pele. A menina banha o Ruiz primeiro. Tira da água. Coloca sobre o banquinho de madeira para enxugar. Seus pezinhos molhados... Zaz! Olha ele caindo... Batendo o queixo no banco.... Os dentes entram na língua. O berreiro traz a mãe assustada. Ao chegar se depara com a pequena "Pietá" sentada no chão pranteando e enxugando o sangue do irmão no colo. 
O calor forte. O tempo podendo mudar a qualquer momento. De repente, nuvens-carneirinhos se juntam apressadas na manta espessa e cinzenta que cobre o céu inteiro. Temporal armado! Ventania sacudindo as árvores de um jeito! Parece querer arrancá-las pelas raízes. Janelas batendo. Estrondosamente. Luise correndo para fechar. A mãe passando apressada para tirar as roupas do arame, invoca... "São Gerônimo! Santa Bárbara!" A menina vai ajudar. Raios cortam o ar, antecipando os trovões e tudo estremece ao redor. Joana rosto crispado mal se desfazendo do fardo da roupa úmida e já correndo para o quarto, levando os filhos menores. Antes de sumir lá dentro, grita para Luise, não pegar garfo ou faca.... "Aço atrai raio." Lá fora a chuva desce em grossas bagas... A enxurrada corre vermelha.... Dentro de casa... Claro-escuro... Meio segundo de breu... Meio de brilho intenso. Trovoada ensurdecedora. Luise tapa os ouvidos com as mãos... Parece que rolam coisas pesadas lá em cima! Frio na barriga. Sabe que depois de tempestades como essa, nem sempre vem a bonança que o ditado diz. Muitas vezes, chegam notícias de todos os cantos dando conta de lavouras estragadas, animais abatidos e pessoas atingidas nos pastos, pelos raios. "Chuva braba, mesmo rápida, pode causar muitos estragos." "Na fazenda do Sr Natalício, dois cavalos e três bois, não se levantaram mais." "Perdem-se muitos". "Cerca de arame é um perigo!" Descampado, também. "Caiu um raio perto do filho do Sr. Quirino que o menino chegou a perder a voz." " Diz que foi tão perto que alguém chegou a ver "machadinha", caindo do céu e cortando a árvore ao meio..." "Cruzcredo!" É apenas a primeira chuva. Muitas virão. Luise esvazia baldes e bacias, pensando na despesa com o conserto do telhado.

\section{0}

E descem as águas. Primeiro as gotas cristalizadas. Fustigadas do céu cinzento. Batem com força na terra. Barulhinho oco. Terreiro salpicado. Pepitas 
brancas para todo lado. A criançada catando e chupando as pedrinhas geladas. Saraivada. Alvoroço. A liquidez torrencial sucede o granizo empurrando os pequenos. Dentro de casa. A contragosto. Luise vai para a janela. Como é bom a gente andar na chuva... Sem sombrinha nem nada... A água escorrendo pelo rosto e braços... A roupa colando no corpo... Os pés descalços na enxurrada... Os pingos grossos caindo da calha. As pequenas vagas se espraiando no chão. $\mathrm{O}$ movimento contínuo e renovado deixa a menina, fascinada... É uma dança! Vê cada gota bater no centro da poça, formar a ondinha circular, ampliar e sumir na borda... É uma bailarina... Pula no centro... O palco se alarga... As outras dançam de mãos dadas em volta dela... Todas de fasto, abrindo espaço pra outra que já salta rodeada, repetindo os movimentos... Lindo demais!

As crianças dentro de casa. A chuva caindo forte, lá fora.

— Hoje não tem roda, pique-esconde, cabra-cega ou pegador.

- A gente pode ler, brincar de teatrinho, jogar balisa.

- A Adma diz que o nome do jogo é Cinco Marias.

— Essa Adma é exibida mesmo. Depois da viagem a Araguari, então... um entojo só.

- Vou pegar as pedrinhas.

Luise sente falta das amigas da Rua da Grota... Aqui, tem essa Adma luxenta, filha única, morando sozinha com a mãe fazendo tudo pra ela... Tem a Estela boazinha, com muitos irmãos pequenos, a mãe sempre adoentada, precisando ajudar no serviço de casa sem quase nunca poder brincar na porta... Tem a Cora Alice morando em frente, quase ao alcance de um grito, mas a Vó não gosta nem de ouvir o nome dela. Não vê com bons olhos. Apelidou de "Coroísta." Vive alertando a Mãe sobre a influência de má companhia. A Cora Alice não é alegre. Diz sempre que vai seguir os passos da mãe legítima... Luise sente o peso da amiga. Tem pena. Tenta afastar seus pensamentos sombrios... "Tá louca?" Não leva a sério as coisas que diz. Cora Alice não é alegre. Filha de criação. Revoltada. A única pessoa da família postiça com quem se dá bem é a Tia Anita, irmã da mãe de criação. Anita teve o azar de engolir um espinha-de-peixe, presa na garganta, só retirada com um pedaço da campainha. Na época, jovem e bonita. Não perdeu a fala. Mas pronuncia as 
palavras de tal maneira fanhosas que não foi poupada da língua do povo. Teve o som da buzina de carro incorporado ao nome. Passou a ser conhecida Anita BipBip. Sobre isso, Cora Alice diz: "Essa gente devia morder a própria língua, ao invés de debochar de quem que perdeu um pedaço da sua". Quando Luise tenta demover as ideias esquisitas da amiga, se vale às vezes do afeto... "A sua tia parece gostar tanto de você... Se insistir em fazer isso, ela que já sofreu tanto, vai sofrer mais ainda... Coitada... Não se importa?" Cora pode às vezes ficar muda ou dar uma resposta atravessada... "Ela não é minha tia de verdade." Ceder nunca. De qualquer forma, numa noite assim, nem mesmo a Cora Alice sairia de casa para brincar fora. E na casa dos outros... "Nem pensar!" Seria a resposta da mãe, se perguntada. Pitida traz as pedrinhas, ganha no par ou impar e começa a jogar. Luise alheia e desinteressada. Há tanto tempo não vejo a Helena...a Marizé...a Cecília, nunca mais.

- Sua vez.
— Pode continuar. Acho que vou dormir.

Na cama, a menina escuta o tamborilar no telhado, doce e suave melodia.

61

Outro dia, vendo a neta, depois de algumas tentativas, conseguindo manobrar os dois barbantes passados pelos furos das duas latinhas de massa de tomate, sob os pés, e caminhar com elas, a avó observou: "De algum tempo pra cá, ao invés de dar atenção pra boneca, Luise tem preferido andar de 'sapato alto' ou passear pelo quintal com a folha de mamoneira, fingindo sombrinha". O que diria D. Mina se estivesse em casa, hoje, olhasse para o outro lado da rua e visse a menina enfeitada com o colar de flor maravilha e os brincos de melão-de-sãocaetano, tentando manter, sem sucesso, as pétalas de moça-velha pregadas com cuspe nos tocos das unhas? Neste momento, a menina é atraída pelo relâmpago verde riscando o céu e trovejando gritaria. Distrai-se com o voo rasante das 
maitacas e acaba perdendo as "unhas". Não se importa. O Délio surgiu na esquina. A carinha ferrugenta combina com o cabelo vermelho pelego. $O$ menino passa, carregando a sacola de lona com as verduras para a mãe e sorri franco. Ela retribui.

- Tenho um gibi novo para te emprestar.

- Vou deixar a sacola e volto.

Délio e Luise já se conheciam da escola, eram bons colegas de classe, e a feliz coincidência dela vir morar na mesma rua dele, permite que desfrutem mais tempo na companhia um do outro: discutem assuntos da escola; trocam revistas em quadrinho; brincam juntos.

Olhando para o lado contrário da casa da família Hildbrandt, pouco adiante da sua, quase em frente à venda dos irmãos De Paula, na qual, Délio acaba de entrar, Luise vê D. Helga se aproximando em passo lento no jeito próprio de caminhar... Tem sorte com os filhos... Délio é ainda muito novo, mas além de estudioso, ajuda ela muito... Os dois mais velhos sustentam a casa, consertando aparelhos elétricos pra a cidade toda... E a Clara...a Clara foi pro convento. "Bonito blumen...” A mãe de Délio tenta se comunicar... "Weiss... Branco... Brilhiante... Edelweiss. Heinrich." " ...esbarra na dificuldade de articular as palavras em português, sacode a cabeça, embaraçada e abana a mão... Guten. Luize corre em casa, pega o gibi, volta e ainda pode ver a mulher se afastando... Mais devagar do que nunca.

Luise não poderia imaginar que, talvez, a figura, que segue adernando o corpo ora para um lado ora para o outro, como um veleiro desconjuntado, pode estar, em pensamento, correndo noutro tempo e lugar. O tempo não se deixa embarreirar. A cena da menina entre as flores pode ter trazido para a mulher madura, imagens e cenários da própria adolescência: paisagem de pinheiros; encostas de montanhas; picos gelados. Da sua terra tinha sido brutalmente arrancada pela estupidez da guerra, como uma criança dos braços da mãe. Não é impossível. Há indícios. Um dia, vendo na casa dela, as três pequenas flores brancas desidratadas, entesouradas na moldura singela, Luise admirou... D. Helga mandou colocar flores do limoeiro, no quadro? Que delicadeza... A menina nunca ouvira falar na flor da neve e jamais poderia saber que o valente alpinista, 
que viria a ser pai do Délio tivera, um dia, o privilégio de colher para a jovem, que seria sua mulher, a rara Edelweis. Talvez, D. Helga esteja revivendo o momento especial. Saindo de casa, apressado, Délio quase esbarra na mãe, que parecia querer disfarçar um gesto: enxugar uma lágrima seca, que ninguém poderia ver mesmo.

Délio e Luise examinam gibis. Os irmãos dela brincam por perto. Élcio, jogando finca, vê a irmã, animada, trocando idéias com o rapazinho, e implica: "Alemão batata, comedor de barata.' "Para com isso, Elcio! O irmão está na vez dele, faz de conta que não escuta e capricha na pontaria. Luise, está de cabeça baixa, constrangida, quando o canivete finca e vibra. Elcio completa a jogada, pegando o instrumento pelo cabo e puxando o risco na terra encharcada pela água da chuva, macia como doce de leite morno, no tabuleiro, ao ponto de corte.

— Élcio, vamos jogar "chutebola" agora?

— Por que não joga com o Zé? Ele tá pedindo há tanto tempo.

— Essa bola de pano não serve pra jogar futebol nenhum. Se eu tivesse uma de cobertão...

Vendo Zé esperando com a bola de meia na mão, Luise tem dó. É o único entre os irmãos a ter um problema sério. Não podia ficar sem o Gardenal, senão... Horrível ver o menino no chão, caído, mijado, babado, se debatendo, sem poder fazer nada. Passado o ataque, mole e sonolento. Os médicos tentavam tudo. A tal sangria era o pior tratamento. O couro cabeludo dele é cheio de cicatrizes dos pequenos cortes. Quando já ia abrir a boca para argumentar a favor dele, é requisita. "Luise vem me ajudar a botar a roupa no sol". A menina está se tornando o braço direito da mãe, principalmente quando a avó não está em casa. "Vem logo, é preciso aproveitar a estiada." Despede do amigo. Atende o chamado, danada da vida e de cara amuada. Quer dar uma lição no Elcio e pensa no que fazer. "Acorda menina, temos que acabar logo com isso". A gravidez de Joana dificulta abaixar. Luise, que ainda não tem altura para alcançar varal, serve para tirar a roupa torcida do balde e entregar para mãe pendurar. Terminado o serviço, vai direto para as gaiolas, abre e solta todos os canarinhos do irmão. Tinha um dó danado dos passarinhos presos e aproveitou o momento de raiva para fazer o que há muito tempo vinha querendo. Élcio vê o prejuízo e abre o maior 
berreiro: "Agora, outros vão pegar. Meus passarinhos são de cativeiro, acostumados a viver presos." Luise não sabia disso, se enche de remorsos, mas não dá o braço a torcer.

— Por que não tenta pegar de volta? Se não conseguir os mesmos, vai logo arranjar outros.

— Você me paga... Vou rasgar seus gibis... Quebrar sua boneca... Vai ver!

62

No entre infância-e-adolescência, Luise às vezes alterna o comportamento. Tem momentos de amadurecimento e de infantilidade evidentes, passando de um estado ao outro de maneira imprevisível.

- Amanheceu chovendo ainda... Ah, não.

- O tempo é das águas, Luise.

- E precisa chover todo dia?

— Que fazer... Pense nas plantas, vão ficar verdinhas e agradecidas. Por que não vai fazer roupinha pra boneca?

Marta entra na cozinha e evita Luise responder.

— Bom dia D. Baratinha, amanhã tem sol? Vó, o que é o que é, uma folha sem beirada?

- A folha da Cebolinha.

— Todo mundo já sabe essa, Pitida.

- O que é o que é tem cabeça, tem barba, tem dente e não é gente?

Essa do alho é velha.

Casa alugada. Muito pequena. A chuva sem dar trégua. O dia escuro emenda com a noite, que parece chegar mais cedo. 
- Tô cansada de ficar passando anel, ouvindo piadas, adivinhando perguntas.

— Fazer o que... Ainda mais agora que a luz acabou?

- Mutuca.

Élcio está com a caixa de fósforos na mão. Todo mundo rodeia a mesa. Alguém traz a lamparina. Elcio acende. Queima os palitos. Faz os pequenos tições.

- Agora a gente finca nas costas da mão, assim.

O menino enfia o carvão no pequeno punho fechado, acende e deixa queimando.

— Quem aguentar mais tempo, é o vencedor.

Luise enfrenta o desafio. Finca dois tições nas costas da mão esquerda. Acende. Deixa as duas brasinhas queimarem até o fim. Sente dor. Não dá o braço a torcer. No dia seguinte... Bolhas. Arrependimento. Soube que a pele ficaria marcada para sempre com dois pontinhos. Se isso dói tanto, como deve sofrer o gado marcado pelo enorme ferro em brasa. $O$ dia continuou molhado. De noite, a mutuca é de novo sugerida.

— Nada dessa brincadeira boba outra vez! Olha a mão da gente como fica. Lá o Ruiz fazendo figura de sombra na parede.

O Élcio grita.

— Eu sei fazer um coelho.

Pitida logo movimenta seu dedo mínimo, tortinho.

— Camelo... Eu sei. 
Figuras de bichos se animam na parede. Desenhos de bonecos de quem não acerta as sílabas são enforcados, no papel, até que o sono chega e leva as crianças para a cama.

Vem novo dia. Acordam e veem a nesga dourada entrando pela cozinha.

- Tem sol!

- Vamos riscar sóis, pra chuva não voltar!

A criançada é arrancada para fora da toca e corre para brincar na rua lavada. O sol brilha. Estilhaços por todo lado.

Cada qual procura o melhor ponto para firmar o calcanhar, girar o corpo, arrastar o pé como se fosse um compasso e deixar o chão marcado por um círculo perfeito. Na terra úmida e fofa, os discos variam conforme o tamanho do pé de quem riscou.

— Pronto, o sol vai ficar.

- Olha o arco-íris lá, gente!

- Diz que se uma mulher passar debaixo vira homem.

— E se for homem vira mulher.

— Falam de um pote de ouro, que pode ser encontrado.

A chuvinha teimosa insistiu peneirando uma ou duas vezes e foi vencida pelo sol. $\mathrm{O}$ astro sustentou o fogo fraco e varou pela tarde até a noite chegar. O dia seguinte amanhece claro. Pela movimentação típica na casa, Luise percebe que a mãe, sumida no quarto, vai ganhar o nenê. Escuta o bla-bla-bla sobre a cegonha e fica calada. Ah, neem... Como nasce eu não sei... Mas com essa conversa boba de um bicho que ninguém vê já não me enganam mais. Senta no batente da porta da sala. Espera. Dali a pouco, escuta o choro.

A família cresceu. Depois de tantos meninos... Uma irmãzinha... Branquinha... Cabelo dourado... Uma boneca. Elenzinha. A Mãe escolheu o nome. Quis batizar em Goiandira... Na mesma igreja em que foi batizada. A Madalena, madrinha de batismo. Eu, de apresentação. No dia do batizado, segurei minha irmãzinha até o padre mandar passar pra Madalena. Agora 
ela e a Mãe são amigas e comadres também. Sou muito orgulhosa de ser madrinha de apresentação da Elenzinha!

63

O Sr. Esteves compra uma casa. A família livre do aluguel. Luise, entusiasmada. Cuida das próprias roupas, sozinha, como verdadeira mocinha que agora de fato, é.

Avalia a sobra de espaço aos pés da cama. Pensa num jeito de pendurar suas vestimentas ali. Aproveita a quina do quarto, martelando um prego em cada parede e atando neles as duas pontas do pedaço de barbante. Prende gravetos roliços, escolhidos a dedo, como cabides. Pendura as roupas com cuidado para não amarfanhar. Principalmente o uniforme com as pregas todas e difícil de ser passado. O ferro à brasa é pesado! Mal termina o trabalho e começa admirar satisfeita com o resultado, é interrompida pela voz de taquara-rachada.

— E aí Luise... Não foi à igreja por quê? Não sabe que faltar à missa de domingo é pecado mortal? A Irmã tava lá, anotando o nome de quem faltou. Vi bem quando escreveu na caderneta dela... Lu-i-se.

Pega de surpresa em cima da cama e de costas, Luise olha para trás e vê a cara da Tita enfiada na porta. Sorriso debochado. Que inferno! Por que achou de aparecer logo nesse dia?

- Ora... Ora... Mas o que é isso... Ha-ha-ha... Um guarda-roupa?... Ha-haha $\ldots$

A menina não passa recibo. Faz o que sempre fazia quando a enteada da mãe era assim desagradável... Sempre. Alheia a provocação, desce da cama, dá uma rabanada e sai carrancuda. Mais tarde, quando a filha do padrasto já tinha ido embora, reaparece e pergunta para a mãe: 
— Por que a Tita tem que ser tão implicante?

— Ora, Luise, você sabe... Ela não tem mãe.

- E por isso, pode ficar pondo defeito nas coisas dos outros, do jeito que sempre faz? Eu não tenho pai e nem por isso... De que adianta ficar chata daquele jeito... Reclamar de tudo? Temos quase a mesma idade, podíamos ser amigas, mas não dá!

— É diferente, Luise.

— Diferente... Diferente... Por quê?

- Perder a mãe daquele jeito...

— De que jeito?

- A Zulmira tava fritando bolinho...

Surpresa, sobrancelhas franzidas, Luise não se contém - Bolinhos!?

— É... bolinhos... desses que a mamãe frita de manhã pra gente comer com café.

A menina arregala os olhos e mal pisca escutando a mãe contar o acontecimento da remota manhã fatídica. "O Esteves a noite toda de plantão na charqueada. A Zulmira levantou cedo e foi aprontar o café antes dele chegar. Na cozinha, começou a preparar a massa dos bolinhos, colocando a farinha de trigo, o açúcar, o leite, os ovos e o bicarbonato... Cadê? D. Lizandra e os meninos continuavam dormindo. Zulmira procurou na prateleira. Achou o pó branco enrolado num pedaço de papel de pão atrás das latas de mantimentos. Pôs uma pitada na massa, misturou, fritou, provou... O pó era veneno e não fermento... coitada morta caída no chão.”

- Credo em cruz! Quem colocou o veneno na prateleira, junto com mantimentos?

- A D. Lizandra disse que quis esconder no alto, por causa dos meninos.

- É muito velha e devia saber o perigo! Podia ter matado a Tita, o Pedrinho, o Berico, o Sr. Esteves... Ela mesma... A família inteira... Já pensou Mãe?

— Pois é... E depois de tudo disso... a Tita ainda ter de ir pro convento...

- Pro convento... Pra quê? 
- Pra ser madre.

- A Tita quer ser madre!?

— Querer não quer, mas vai assim mesmo.

- Por que isso?

- Pra fugir de praga-de-madrinha.

— Que praga? Qual madrinha?

- A madrinha dela... a Jandira, filha do Sr Nestor da serraria.

- Sei... A tia da Eli.

- Ela mesma. Pouco antes de morrer, Zulmira e ela tiveram uma briga feeia! Não sei o motivo. Só sei que foi coisa grande... Todo mundo entrou na confusão... O Esteves... A D. Lizandra... E no meio do 'pega pra capar', perderam o rumo e o prumo quando a Jandira esgoelou praga horrível: "Vocês todos vão me pagar. A Tita vai crescer e virar mulher da vida... mulher à-toa, vocês vão ver!"

— Nossa Senhora d'Abadia... Mãe!

De noite, Luise custa a dormir, pensando na sina triste da Tita.

64

A nova casa plantada numa esquina da Rua Cristalina é ladrilhada de pedrinhas brilhantes, como tantas outras da pequena cidade. Terra batida. Em áureos tempos, muitas pedras preciosas encontradas. A construção oferece vista para os quatro cantos do pequeno mundo. Janelas na frente, nos fundos e nos lados. As dos quartos abrem para a rua lateral e as do outro lado escancaram para o muro do quintal vizinho. Com a cobertura verde, não é cerca qualquer. Canteiro vertical. Quadro vivo, cambiante, sempre pintalgado. Ora florezinhas roxas caindo no chão, ainda perfumosas, formando delicado tapete, no sombreado. Ora pingentes de ervilha sobrevindo, tidos por Vó Mina como excelente acompanhamento, nas refeições. Casa maior. Um quarto destinado para as duas filhas maiores. Um cômodo contíguo e independente para Vó Mina. Satisfeita em resgatar um pouco da liberdade perdida, pretende fazer do lugar lar privativo. Não 
dá certo. É rendida pelos netos querendo sempre da comida da Vó. Larga para lá o fogãozinho de tijolos improvisado para cozinhar coisas que gosta como as vagens de ervilha que Luise prefere pendurar pelas finas hastes nas orelhas e sair passeando pelo quintal com sua sombrinha de folha da mamoneira. Ah, o ensolarado quintal! Terreno de capoeira com as poucas árvores frutíferas plantadas, lutando para crescer entre pedregulhos e malacachetas. Num dia muito especial, a porta da cozinha se abre para ele e dá passagem ao novo habitante. Chegou introduzindo novos sons e movimentos, ao palco de aventuras. O nome dele era Lulu. Branquinho e peludo, o nome lhe prestava bem. Ganhado de uma vizinha. Recebeu a atenção das crianças todas. Até então, brincavam de vez em quando com animais domésticos dos amigos, dos vizinhos, sem ter próprio. Pego de mão em mão, solto pela casa, livre pelo quintal, o cachorrinho cresceu manso e dócil. Bobo de tanta carinhança. Familiariza-se ao ambiente. Fazia esquecer que nem sempre estivera ali. Não estivera. Nem por muito tempo estará. Qual bravo Davi, porém desprovido da funda, reage a Golias mecânico. Na desproporção, os pequenos latidos abafados pelo terrível rugido do gigante rua abaixo. Em desabalada carreira, desconjuntado, passa sacolejando a carga fúnebre escalpelada e esquartejada na serraria da Rua de Cima, deixando no ar o perfume de vida que ainda exala das achas douradas... e... Oh! No meio do chão batido da Cristalina, o chumaço estendido passando gradualmente do branco ao vermelho vivo, ante os olhinhos petrificados que benditas cortinas úmidas vêm toldar, tornando a imagem impressionista e tirando dela a crueza. Alguém sugere um filhote substituto. Preferem ficar com Lulu. Na lembrança. A casa fecha a quadra. O quarteirão seguinte começa no depósito de cobras do Sr. Faustino. Para assistir espetáculo da retirada de veneno, que ele manda para o Instituto Butantã, em São Paulo, basta atravessar a rua lateral. Ele prende a cobra pela cabeça com uma espécie de forquilha. A víbora morde o frasco posicionado para receber a peçonha, expele o veneno grosso, leitoso e viscoso que escorre lentamente pelas paredes do vidro transparente em direção ao fundo.

A cena passou pela cabeça de Luise, muitas vezes, vista e revista... Voltava para casa, correndo pela Rua Detrás, viu a cobra, nem grande e nem pequena, atravessando o caminho. Pega no meio passo, sem poder retroceder e nem conter o pé, que desceu em cima do animal de sangue frio e subiu como mola. O próprio sangue gelou nas veias da menina que continuou disparada e só parou quando 
estava longe e sentiu-se segura. Olhou para trás. Nada a ser visto. A víbora enveredara no capim? Por que não mordeu? Não sabia a explicação. Talvez, tenha pisado numa região do corpo, que impediu o ofídio de armar bote. Cascavel não era. Não tinha chocalho. A menina está perto do serpentário lotado... A mãe diz que cobras costumam assobiar para chamar outras...

65

Outra novidade da rua é o perneta. Passa todos os dias cantando o mesmo pedaço da cantiga.

Eu tô doente, morena.

Doente eu tô

Cabeça inchada, morena.

Tô e tô e tôn ${ }^{11}$

Sempre repetindo e tornando a repetir a mesma parte. O canto e o toc-toc da muleta subindo ou descendo a rua, todos sabem: "O Sr. Zé está passando" Metódico. Sempre nos mesmos horários. O povo já nem precisa consultar relógio para controlar alguns compromissos. "Tá na hora”. Até a Mãe, morando aqui há pouco tempo, acha o vai-e-vem do Sr. Zé Paixão confiável como um bom relógio. 'Paixão', sobrenome? Apelido que ganhou por causa da música que canta?

Luise entra na sala e encontra a mãe com a tesoura aberta anelando as franjas do papel de seda que colara em volta dos cartuchos de papel pardo

\footnotetext{
${ }^{11}$ Trecho de canção sertaneja.
} 
recheados de amendoim caramelado. A menina enche os olhos com o arranjo do cesto de balas de leite, já prontas e embrulhadas. Um ninho macio e multicolorido. Não podia ficar mais bonito! Sabe que "é pra depois".

- Mãe... Hoje, vi tantos estandartes tremulando com a figura de São João, o Menino de cabelo encaracolado, o carneirinho e o cajado, no alto dos mastros fincados nas entradas de muitas casas.

— Ele é muito cultuado na cidade. Até catalanos que moram fora costumam vir celebrar o dia Santo aqui.

— Por que a festa não é feita lá na capela dele?

- Antigamente era. Ah, coisa linda... Tinha que ver. A gente jantava por volta das quatro horas da tarde e subia a pé... criança, velho, moço... colorindo as duas estradas que levavam ao morrinho...

- Quais?

- A Rua do São João e a Rua da Capoeira. A gente subia apanhando flores do campo, rindo, brincando... Alguns combinavam encontros pelo caminho pra terminar de subir junto conversando e apreciando a paisagem nas tardes friiinhas de junho.

— Demorava a chegar?

- Uma hora, mais ou menos... Na parte mais difícil, a gente ia mais devagar pra aproveitar a tarde fresquinha e o ar puro. Lá em cima, depois de entrar na igrejinha, rezar, confiar os problemas e pedir ajuda a São João, a gente saía e descansava sentados na grama fresca.

- Tinha barraquinha?

— Só o toldo... O coreto dos leilões... Os bancos rústicos. Mas as pessoas levavam água, café, fruta, biscoito...

- O padre subia a pé?

- De primeiro, sim. Depois aparecerem os automóveis e um fordinho levava o sacerdote e as cantoras, Benvinda de Deus com a turma dela, por conta do festeiro.

- A capelinha é muito pequena...

"Na hora do terço, parte dos devotos ficava dentro da igrejinha lotada e parte do lado de fora, todos rezando com a mesma fé, devoção e respeito. Depois, 
vinha o leilão. Apregoado quase sempre pelo Totônio Fogueteiro. Era ele que fazia a exibição das girândolas e soltava os foguetes, na última novena, depois da 'levantação' do mastro. Nos intervalos do leilão, música de orquestra ou tocada pela Banda de Catalão. A descida começava lá pelas sete, oito horas... Nas noites de lua, a volta era muito agradável, romântica, poética... Casais amigos desciam a ladeira, com calma, cantando modinhas alegres ou mesmo canções barulhentas. "Depois da última novena, a procissão do mastro com balõezinhos, a queima da fogueira enorme e a exibição de girândolas... A gente ficava no morro até lá pelas dez pelas doze horas da noite, aproveitando a claridade da fogo". Luise escuta a mãe e imagina os ritos da festa... Tudo muito parecido com o que já conheço. Na cabeça da menina, cantoria de modinhas, conversas sobre promessas feitas, milagres do santo, simpatias e tentativas de andar sobre as brasas, por fim. "No dia seguinte, a alvorada, os morteiros, os foguetes, a música e a missa rezada às noves da manhã, na capela, com o povo todo, participando..." Casamentos... Batizados... A diferença que vejo entre a festa de São João e a de N. Sra do Rosário é a fogueira, no lugar da congada... "Antes do almoço...” Já sei... a ‘tiração' de esmolas, café e dança na casa do festeiro... À tardinha, a procissão em volta do morro, os Senhores disputando o privilégio de carregar o andor de S. João... Anjos e virgens cumprindo promessas... Alguns subiam o morro de joelhos, na estrada retocada todo ano, pra facilitar o trajeto...” Ah, tem essa diferença também. Por fim, a distribuição dos cobiçados cartuchos de amêndoas, como estes.

- Por que parar com uma coisa linda dessas!?

- Os padres norte-americanos da congregação Franciscana chegaram pra ficar no lugar dos espanhóis da congregação Agostiniana e proibiram as festas.

- Acabar com as tradições... Por quê?

- Estranharam a alegria das comemorações... Disseram que a festa era... "Profana." O povo ficou sem entender nada.

- O que é "profana"?

— Nem sei... Deve ser desrespeito à igreja... Acho... Não entenderam a devoção misturada com tanto riso e alegria.

- E o povo... Aceitou sem reclamar?

— Nãão... Ficou todo mundo pasmo. Ninguém podia entender como uma dedicação piedosa a um Santo podia ser considerada... "profana". 
Luise prestando atenção no que a mãe diz... "Tinha que ver... O povo lamentava, inconformado a saída dos espanhóis, lutou anos contra a atitude dos franciscanos. Pouco adiantou. A Festa morreu. O Morro da Saudade ficou solitário nas tardes juninas”. Lembro que foi em 1946, você pequenina, que foi construída a primeira igreja no alto da colina, por iniciativa de três Joãos, e ganhou o nome de São João, no Morro da Saudade.

— Três Joãos?

— Três Joãos: João de Cerqueira Netto, João Patriarca e João Antonio de Macedo. Daí, outro João, enciumado por não ter sido convidado para participar da construção da capelinha, mandou colocar as três cruzes no morro do lado contrário, que passou a ser chamado de 'Morro da três Cruzes.' Lembro que em épocas antigas, na falta d'água ou atraso das chuva, uma procissão costumava subir levando águas e flores para aguar o lugar e enfeitar as cruzes.

- Que lindo!

"Pois então... a capelinha no alto do morro mesmo passando por limpeza todos os anos, certa vez, tava caindo aos pedaços... Fizeram uma movimentação... organizaram festas, rifas, leilões pra angariar fundos para grande reforma... Nós mesmos contribuímos pra reconstrução e ampliação da igrejinha de São João, que foi elevada a santuário... Um único franciscano quis compreender a devoção verdadeira de nossa gente e se esforçou para reavivar a "celebração 'pitoresca', como ele disse". Aquele cruzeiro com luzes foi instalado lá cima mais tarde pra iluminar a subida por ocasião das novenas... Não conseguiu. Hoje a festa é feita por uma comissão de festeiros, perdeu a força e o espírito de tradição. As famílias homenageiam o Santo como podem... Lembra a mesa enorme e o foguetório naquela casa que fomos o ano passado, uma noite antes do dia da festa? Algumas, como aquela... novenas que antecedem a festa... mesas de doces e quitandas... foguetório e queima de fogueira na noite da véspera... Outras, com bem mais simplicidade, alguns doces, brincadeira, simpatias, em volta de um bom fogo crepitante... Depois que as labaredas apagam, aproveitam as brasas, para assar milho, batata-doce, mandioca, com muita alegria, risada e boa prosa. E, no final, há os que se divertem tentando caminhar no borralho. Alguns costumes continuam. Como aquele das mocinhas que, na véspera, escrevem os nomes dos pretendidos em pedaços de papel separados, enrolam em canudinho, colocam debaixo dos travesseiros, antes de dormir, para ver, na manhã seguinte, no que 
estiver aberto, o nome do destinado. Outro considerado muito importante é levantar antes do sol, tirar água do poço, despejar na bacia e ver o rosto refletido no espelho d' água fresquinha. Aquele que não conseguir ver a sombra da própria cara... Não verá outro São João. No ano passado, o Sr Manuel, sacudido e parecendo são, depois de muito tentar, disse... 'Eu não consigo ver o "deabo" da minha cabeça!' Coitado. Morreu logo depois do Natal.

Ora, a panela de grude some... Ora, a lâmina desaparece. Do lado de fora, rodeados de varetas de bambu e sobras de papel de seda, sentados no chão, os filhos dividem com a mãe a tesoura e a cola caseira fazendo papagaios. Ela não se aborrece. É antevéspera. Sabe que não precisa correr. Tem tempo.

67

Mãe e filha estão distraídas, quando a figura assoma perto da porta da cozinha, repentinamente.

- Tarde.

— Ai, que susto, Joaquim! Boa tarde... Leva a lenha lá pros fundos... Ainda não varremos o lugar da fogueira.

- "Certim".

Joana supervisiona o trabalho do Lenheiro, empilhando os gravetos encostados na parede.

- Com mais esse feixe, já tenho o que chega pra fazer uma bonita fogueira e deixar São João satisfeito. Obrigada, Joaquim. Aqui tá o dinheiro. Tá com fome?

- Tô.

Joaquim sobrevive da caridade alheia, ganha comida em quase todas as casas da cidade. O dinheirinho que arrecada, catando lenha no mato, é todo guardado nas trouxinhas de pano que sempre traz penduradas em volta do corpo. Luise entra na cozinha a tempo de vê-lo se esparramar no chão com a carga de 
trapos pendente da cintura. Por causa desses molambos todos, o Joaquim parece mais gordo do que é. O homem parece própria calma em pessoa, quando desata uma das bolsas improvisadas, abre o trapo em cima dos joelhos e guarda o parco pagamento junto com uma porção de notas emboladinhas que já estava dentro dela. Joana vem do fogão trazendo um prato cheio com sobras do almoço, dirige um olhar significativo para a filha e pisca um olho.

— Joaquim, tá juntando esse dinheirão pra quê?

Mesmo preparada pela mãe, Luise não deixa de se surpreender com a transformação do homem. Levanta o rosto iluminado pela aura de um sorriso enorme e responde no seu jeito estertorado de falar.

— Pra-com-prar-um-ca-mi-nhão.

— Um caminhão?

— Um-ca-mi-nhão-ma-re-lo...

- E você quer um caminhão amarelo pra quê?

O riso alargado do homem bota para fora dentes quadrados e sadios. Os olhos dele brilham como os de um uma criança falando do brinquedo desejado.

— Pra-car-re-gar-as-mo-ças-bo-ni-tas... Ha-ha-ha...

A mãe acompanha o Lenheiro na gargalhada. Ele é ainda novo e até bonito. Joaquim começa a comer e volta ao que era. Calado. Sério. As colheradas vão para a boca, uma seguida da outra, com impressionante rapidez. No prato, a montanha já vai pelo meio, quando a dona da casa pergunta:

- Água?

- Quero.

- Quero.

$\mathrm{Na}$ cozinha já algum tempo, olhando fascinado para o brutamonte, que engole a comida com voracidade e quase sem mastigar, Élcio faz coro na resposta. 
A mãe traz água para os dois. Num segundo, o imprevisto acontece. A criança avança inesperadamente e... Zaz! Despeja o conteúdo da caneca no prato do Lenheiro de uma vez só como sempre faz no próprio. Na nesga de sol que entra pela janela, Joana mal pode perceber o reluzir. Salta com um grito... Arranca o filho fora do alcance da faca de aparar gravetos... A lâmina desce como um raio e corta o vazio. Luise, coração aos saltos, assiste a carraspana que a mãe dá no sujeito... "Então, não vê que é só um menino e não queria te fazer mal nenhum?" Joana fala até se dar conta de que estava perdendo seu tempo com as zangas. Diante dela, o lenheiro humilde de antes, devora sua comida fria e aguada, ouvindo como se não fosse com ele. Cabeça baixa. Mutismo habitual. Acaba de comer. Levanta. Vai. Tem sempre alguém esperando, por ele. Coletar gravetos secos no mato, guardar o dinheirinho preso no corpo, o jeito que o Lenheiro achou de tocar a vida adiante. Que seria da criatura se não pudesse sonhar? O sonho não deixa o homem parar. Da porta, Luise vê o Lenheiro dobrar a esquina a passos largos "...quinze, dezesseis..." e acaba perdendo a conta das trouxinhas que sacolejavam em torno da cintura dele... Pelo menos vinte.

Morando ainda na Rua das sete Casas, Luise assistia às vezes aos jogos no campo do Catalão Futebol Clube, bem perto de casa. Lá, conheceu Lélia, Ivone, Marta e Lena moradoras da Rua Cristalina, que aproveitavam o espaço para jogar carimbada, orticã... Lélia e Marta ótimas jogadoras. Lena e Ivone jogam bem. Luise se esforça. Serve para completar time. Desde então, a menina se dá bem com o grupo e agora que se mudou para a mesma rua, a amizade se solidifica. Marta e Lena vivem com o pai numa das melhores casas da rua. Eletricista, trabalhando na companhia de força e luz, Prada, o Sr. Zé é bom pai, até a hora que começa a beber e vira outro. Nos fins de semana, pode encher a cara até cair. A mãe delas foi morar em São Paulo. Ganhar a vida como cozinheira. Em contato constante com as filhas, pelo correio. Suas cartas chegam frequentemente acompanhadas de caixas enormes de roupas, novas e usadas ou outros presentes. 
"As meninas do Sr. Zé" como são conhecidas não comentam a ausência e nem reclamam a falta da mãe. Uma vez ou outra, deixam entender discretamente que a escolha dela tinha sido a melhor para todos. Há quem comente brigas do casal, "frequentes e infernais". As filhas cuidam bem da casa. Herdaram o jeito da mãe. Cozinham bem. Comidas diferentes. Receitas novas vindas de São Paulo. Por ocasião do Natal, Luise tem a oportunidade de provar o peru assado por elas. Compraram a ave e cuidaram dela no quintal. $\mathrm{Na}$ véspera, passando por lá, Luise encontra a Lena abrindo o bico da ave e a Marta enfiando o gargalo da garrafa para despejar bebida goela dela abaixo:

— Tá dando cachaça pra ele, por quê?

- Pra carne ficar mais macia e gostosa.

Quando o bicho já não se aguentava mais nas próprias pernas, foi solto pelas irmãs às gargalhadas. A menina estava sem tempo e não ficou para ver o fim do espetáculo bizarro. No dia seguinte, saboreou o pedaço que lhe deram para provar.

— Tá bom demaaais!

Comprovou que a Lena e Marta entendiam mesmo de cozinha. "As meninas do Sr. Zé" são alegres, estudiosas e dançam bem. O pai frequenta o clube Treze de Maio. Algumas vezes, levando as filhas junto. Consente de vez em quando que reúnam amigas e amigos para uma tarde dançante.

A Lélia come o pão que o diabo amassou, vigiada sem trégua, pelos irmãos mais velhos e brabos demais.

A Ivone também é muito controlada pela avó, com a responsabilidade de criá-la, depois que a mãe dela morreu. Tinha outras filhas. Mas só a neta morava com ela. Escutando um cochicho de que o avô, Sr. René, dizia que criava as filhas para ele mesmo, Luise não entende... Ninguém explica.

As amigas começam a ter o interesse despertado para os meninos e se divertem juntas nos fins de semana. Chegam mais cedo ao jardim e entram no vaie-vem das moças, passeando na ala formada pelos rapazes nos dois lados do passeio em frente ao Cine Real. Tudo que precisam para ser felizes é o footing e o cinema. A sessão do sábado, a matinê de domingo, a "Sessão de Gala", 
domingo à noite, sempre com um filme especial. Animadas por balinhas "Imperial", quadradinhos de "Quarto Centenário" e "drops Dulcora". Para a felicidade completa, um picolé lambido, antes ou depois da sessão, num dos bancos do jardim, coco queimado, creme ou groselha... Que delícia! E tudo acaba por voltas das dez horas, quando voltam para casa e dormem contentes.

Domingo, depois de assistir "Caruso", Luise entra no quarto e procura se deitar sem fazer barulho para não acordar a Pitida, a sono solto. Ainda emocionada sob o impacto da beleza das músicas, a menina pensa no filme até dormir. Logo é acordada de novo. Que barulho é esse? Entreabre os olhos e vê a irmã dormindo tranquila na cama em frente à sua. Sente uma presença no quarto. Permanece quieta. Olhos semicerrados. No fundo do corredor entre as camas, a porta de comunicação com o quarto da avó. De lá, um rapaz vem e volta. Parece indeciso. Luise finge dormir. Pensa no que fazer. Na obscuridade do quarto, palmilhando o chão dos pés para as cabeceiras das camas, o rapaz para perto da Pitida, corpo curvado e olhando para ela alguns segundos. Depois, vem para perto de Luise, fica um tempinho, do mesmo jeito dobrado, observando a menina. Ela já tem seu plano. Espera a chance de colocar em ação. O rapaz volta para os fundos do quarto e fica algum momento, parado, talvez decidindo seja lá o que for. A menina senta na cama de chofre e solta um grito agudo e estridente, no melhor estilo cinematográfico das atrizes de Holywood, que vira atuando nos filmes. Pego de surpresa, o homem passa esbaforido entre as duas camas e voa porta afora. O Sr. Esteves e a mãe aparecem no quarto assustados. Encontram a porta da cozinha escancarada. $\mathrm{O}$ invasor fugira por ela. Concluem que fecharam a casa e foram deitar, com o rapaz já dentro da casa. Talvez escondido no cômodo de Vó Mina, que estava fora. Joana lembrou a vez que uma amiga dela foi se deitar numa noite em que o marido não estava e viu pelo espelho da penteadeira um homem debaixo da cama. "Deu alguns muxoxos, fingiu ter esquecido alguma coisa, foi buscar ajuda, e o sujeito foi pego.” Todos retornam para as camas. Noite longa. 
Pitida assustada. Fazendo perguntas. Pedindo para Luise repetir tudo. De novo. De novo. DE novo. A menina cansada da história, começa falar do filme do Mário Lanza e Pitida acaba dormindo. No dia seguinte investigam. Desconfiam do hóspede dos vizinhos da frente. Disseram que o moço tinha partido cedo. Nada descoberto. De dia... “Será que ele vai voltar?”. De noite, antes de deitar, o ritual repetido: olham debaixo das camas, verificam o cômodo de Vó Mina, certificam as travas das portas. Todas as noites. Desassossego. Apaga logo essa luz!", ordena o padrasto. No escuro o medo cresce... O sono medroso e fujão saltita.. Vai... Vem...

— Luise! Tá dormindo, Luise?

- Tô tentando.

- Escutei um barulho...

- Não é nada... A não ser... Quem sabe o ladrão trazendo uma faca...

- Para Luise!

- Medrosa! Tô só brincando,

- Posso dormir com você?

O invasor não aparece mais. Com o tempo o incidente esquecido..

Voltando da escola, Luise tomada pelo mal estar. A cabeça rodopia. A ponte oscila. A caminhada se torna árdua. A casa parece tão distante. Chega e cai na cama. Por muitos dias, imersa num turbilhão de dor de cabeça, febre alta, delírio, formas enormes que não consegue identificar. Chás de sabugueiro e infusões de casca de beladona não adiantam. Pegou a doença da vez. Para enfrentar a gripe asiática que grassa e alastra, é preciso injeção. Pior do que a dor da picada é onde a aplicação precisa ser feita. "Na popa é melhor." Diz o farmacêutico logo no primeiro dia. Luise envergonhada. Mostrar o bumbum pra um estranho... Que raiva! Dias e dias de aulas perdidas. Preocupação com 
as provas finais. Curada, se entrega aos estudos e recupera o tempo perdido. Nos exames, se sai melhor do que esperava. Termina o curso primário com dia e hora marcados para comparecer ao Colégio Mãe de Deus, sem grandes explicações.

Pela primeira vez, Luise adentra o pátio do Colégio Nossa Senhora Mãe de Deus. Quando assisti a "Dança das Flores" fiquei atrás da balaustrada que rodeia o corredor das salas de aula e só vi a parte que servia de palco. A menina caminha leve e despreocupada. Palmilha a terra batida, sem ter noção real da importância de estar ali. Sente a brisa... Faz cócegas... Assanha a mangueira... As folhas farfalham... As flores tremulam. Ainda é cedo. O sol já se derrama. Fartamente. Luz e sombra brincam de esconde-esconde. Qual delas vai vencer esse jogo? Depende do vento. Quando parar de soprar, o resultado mostrado no rendilhado do chão. Escuta algazarra dos passarinhos mimetizados nos galhos mais altos... Torcem? Luise está alegre. Sem razão aparente. Algo de bom iria acontecer? Sentimentos portariam sinais?A intuição mandaria mensagens... Boas... Más... Pelas sensações? A gente poderia interpretar se prestasse a devida atenção? Há mais coisas entre o céu e a terra... De repente, no campo de visão, ao lado da mesa de pingue-pongue, no sombreado ao fundo, recostado na cerca que separa o pátio do pomar, olhando para baixo, descontraído, mexendo com os pés cruzados, levanta a cabeça... Flashsss... Menina... Menina... Frente a frente... Alguma coisa acontece no encontro de olhares... Quem sabe o quê? Atração. Sintonia. Magnetismo. Arrebatamento. Reconhecimento instantâneo de quem nunca se vira antes. Por quê? Tudo some. Da vista. Da cabeça. No instante eterno. Sustentação invisível. Dimensão à parte. Frequência particular. Esfera de sonho. Magia. Vácuo. Um entre, cavado por força do encantamento. Quebrado pela realidade. A prova que vieram prestar. Não na mesma sala. Não trocam palavra. Quando termina, Luise vai para casa sem vê-lo mais. Leva a imagem. Na cabeça. No coração. Flutua com o segredinho bom. Está bem guardado? Ninguém vai perceber? A coisa é grande. Quente. Forte. 
Transcende. Entorna no silêncio. Espalha cheiro. Sai pelos poros. Emerge das dobras do corpo. É toda exterior. Irradia na pele. "Os olhos da Luise parecem mais verdes". Diz alguém. "Reflexo da cor dessa blusa?" "Reparou as sardinhas no rosto dela?" "Puxou a mãe". Está presente em tudo o que faz. No riso fácil. "Viu passarinho verde?" "Nossa, encorpou, de repente." "Comprei o seu primeiro sutiã.” Ai, que lindo, esse meu sutiã! A Mãe chegou com ele... Que surpresa! Branquinho... Macio... Deu direitinho. Esse é o presente mais bonito que até hoje me deu! Gosto também do meu anel de chapinha... O alvoroço todo por conta daquele calorzinho que dava conforto. Fazia dispensar comida. Perder sono. Onde estaria o responsável pela revolução? A menina não sabe. É feliz só em saber que ele existe em algum lugar da cidade. Luise passou na prova de seleção. Soube antes do Natal. Ganhou a bolsa de estudos. Vai estudar no Mãe de Deus. Ele também, com aquela cara de inteligente, decerto. Vai estudar no São Bernardino de Siena... E quando as escolas desfilarem juntas de uniforme de gala na Avenida... Ah!

— Luise, encontrei a Leontina na rua e ela me disse que tá muito apertada de costura. Perguntou se pode ajudar.

— Eu... Como? Não sei costurar, Mãe...

- Bobagem... Já fez tanta roupa de boneca... Bordado pra sua professora... É serviço de mão. A Leontina ensina. Aproveita as férias pra ganhar um dinheirinho.

Luise começa a passar algumas horas das tardes, imersa nas cores do arcoíris, aprendendo a distinguir diferentes tecidos... Musseline... Fustão... Piquê... Cambraia... Chiffon... Seda... Georgette... Javanesa... Chamalote... Renda... Organza... Morim... Laise... Gabardine... A reconhecer linhas.

— Você pensa que linha é linha e pronto? Nada disso, minha filha, cada pano pede uma diferente... 
- Como saber a certa?

- A linha tem que estar de acordo com o tecido, a costura... É preciso pensar em resistência, suavidade, espessura, cor... Pano mais grosso, linha mais grossa... Linha fraca em tecido grosso arrebenta. Um bom teste é tentar partir a linha com a mão... Cuidado pra não se cortar!

\section{A Leontina entende mesmo do "riscado."}

— Fio fino serve pra pano delicado... Se o tecido é fino e leve, tem que usar linha suave, lisinha...

— Como saber se a linha é assim?

- Passe o fio no lábio. De novo, cuidado pra não se cortar! Num tecido de trama aberta, a linha tem que ser mais espessa. O risco de ter um fio puxado depois, é menor. Fio grosso também é usado em trabalhos decorativos, bordados...

- E a cor?

- Depende do efeito que busca... Quer combinar com a cor do tecido? Contrastar? Se o pano é xadrez ou listrado, a dica é escolher a cor mais escura.

- Pensava o contrário.

- Parece que o olho humano repara mais num detalhe claro sobre uma base escura do que o inverso, a cor mais escura disfarça a costura.

Não demora muito e a menina aprende a lidar com o material usado pela Leontina. Alinhava enfeites: renda, fita, gorgurão, sianinha... Prega botão, colchete, chuleia, faz bainhas... A costureira sempre por perto com a atenção voltada para o serviço dela. "Em fazenda delicada como essa, não poderia usar o ponto 'espinha de peixe' pra fazer a bainha". Trabalhando com o ponto invisível, a menina está pensando em coisas que não podem aparecer também. A Leontina mora aqui sozinha... Casa triste meio escura... Costura o tempo todo. Faz roupas lindas! Deixa as pessoas mais bonitas, felizes e isso é bom. Claro. Bom o bastante? Será que a Leontina gosta mesmo do que faz? Quer passar a vida inteira assim? Ou de vez em quando tem vontade de largar tudo? Teria coragem ou medo de experimentar vida nova? Ela faz vestidos pra todas as ocasiões... Vestidos do dia-a-dia, vestidos de festa... Vestidos de passeio... Vestidos de noite... Vestidos de noiva... $E$ até vestidos de luto e 
enterros... É prendada. Não é feia... Não tem namorado... Não fala em casamento. Trabalha tanto pra quê... Acho que costureira nem ganha tanto dinheiro... Luise olha para a costureira folheando uma revista "Burda." Procurando um belo modelo, decerto. À noite sonhamos... Será que a Leontina se apronta em sonhos? Experimenta as roupas que faz? Veste, de noite, alguns dos vestidos que costura, de dia, pras outras? Encanta-se com um modelo perfeito e perde a vontade de tirá-lo? Sente-se transformada, bonita... Vai à festa disfarçada com pintura, máscara, sei lá... Passeia... Dança... Namora... Como nos filmes... No sonho vale tudo. Claro.

Fevereiro. Carnaval! Domingo. Matinê no C.R.A.C. A banda abrindo o baile.

Taram, taram taram,taram

Tam, tam, tam tam,tam, tam, tam

Taram, taram taram,taram

Tam, tam, tam tam,tam, tam, tam...

Salão cheio. Som das marchinhas. Vai e vem alegre. Voo de serpentinas. Chuva de confete. Multicor. Jogam da plateia. As mães confortavelmente instaladas nos conjuntos de mesas, contornando a pista. Crianças menores, no colo. Maiores saltitando ao redor. O fluxo de jovens. Marchando. Cantando. Bisnagas douradas nas mãos. Segue pela direita. Volta pela esquerda. Luise de branco. Lenço verde na cintura. Numa das idas, quase chegando ao fundo do salão apinhado, entre as pessoas paradas a beira na pista... Ele! Encontra o olhar do menino. O coração dá um salto. Passa a bater disparado. As pernas bambeiam. As mãos gelam. O rosto arde. Levada pelo fluxo. Ele a observá-la. Ela chegando perto. Ele segura a mão dela. Segue dançando junto. Ela, mão presa na dele, não sente mais os pés no chão. Flutua no meio dos jovens foliões. Tudo é sonho. $\mathrm{O}$ cheiro do lança-perfume no ar. A música. A viravolta. O tempo não para. 
Taram, taram taram,taram

Tam, tam, tam tam,tam, tam, tam

Taram, taram taram,taram

Tam, tam, tam tam,tam, tam, tam

O baile acaba. Menino e Menina, frente a frente, olho no olho.

— Qual o seu nome?

— Luise. O seu?

- Auro.

Falam da prova que fizeram. Ele confirma que vai para o Ginásio São Bernardino de Siena, só para rapazes. Ela conta que vai para o Colégio Nossa Senhora Mãe de Deus, exclusivo para moças. Conversam. Ele marca encontro no jardim para o próximo domingo, no horário da matinê. "Espera na porta do cinema." Despede-se. Luise volta para casa... Eu estou namorando?! Enamorada, mal pode acreditar. Vive em névoa rósea... Dia... Noite... Que importa? Que passe depressa para o domingo chegar. A menina vai cedo para a porta do cinema. Na fila, o coração pergunta... "Será que ele vem? Será que ele vem?" Mesmo sem ter visto, reconhece a voz... "Guarda um lugar para mim." Sussurra em seu ouvido. O cheiro dá vertigem. Tonteia. Sensação de voar. A mesma que sente na cadeira voadora do parquinho, do lado da estação, rodada velozmente. Luise entra. Reserva lugar ao seu lado. Com o sinal de que a sessão vai começar, o Auro virá. Assim fazem os namorados. Assim, a menina faz. E o menino vem. Senta. Pega a mão dela. Momento perfeito. Ah, se os momentos da vida fossem todos assim. O tempo inteiro do filme sem se mover. Não arrisca a perder o contato. Felicidade maior podia ter do que assistir o filme inteirinho de mão dada ao namorado que já conheceu gostando? Fins de semana de pura alegria. A terra podia parar de girar nas matinês de domingos. Mão na mão, e o filme sem acabar. Felicidade para sempre. Como no The End das películas que os dois assistem juntos. 
Algumas vezes, a menina vai à igreja durante a semana. "Luise, é quaresma, não deve ficar tanto tempo no espelho.” Dá uma escapadinha e passa pelo jardim já combinada com o Auro. Caminhando nas nuvens. Feliz ao lado dele até o largo da matriz. Conta com a solidariedade das amigas. Acompanham a certa distância. Esperam com paciência ela conversar mais um pouquinho antes de se despedir. A conversa parece não ter fim. Com o corpo dele perto... O cheiro... A voz... Pra mim, isso é felicidade... Não importa mais nada. Na via-sacra, Luise segue o grupo guiado pelo padre, de estação em estação... "Jesus cai pela primeira vez." Parada diante do quadro, cabeça para o alto, a imagem do sofredor evoca outra pessoa... Trilhou calvário parecido... Foi ao chão muitas vezes... Empurrado pelas ruas, ferido pelos algozes, levado pra morte aos murros e pontapés... Corpo retalhado por cem facadas... Sangue escorrendo por todo lado... Roupas em farrapos... Torturado até a encruzilhada... Caiu pela última vez. Os assassinos, vendo que ainda estava vivo, varando coração dele com um punhal comprido. Gargalhavam... Davam tiros pro alto... Tentavam jogar as montarias em cima. Os cavalos refugaram e saltaram sem pisotear o corpo sem vida.

O que poderia ter acontecido se o Antero não tivesse conhecido a Amélia e se apaixonado por ela? Teria morrido velho? Escrito um mundo de poemas? Quem sabe... O pai da Amélia não era diferente de qualquer pai daqui... Expulsou a filha de casa, porque "se perdeu" com o namorado. Ela foi embora pra Campo Grande e lá, com o tempo, passou a comandar uma casa de mulheres. Conheceu o poeta de Jataí. Convenceu a vir pra cá. Podia saber que estava trazendo o moço pra morte? Ele veio. Assentou com ela. Conquistou respeito. Ganhou confiança. Apoio. Montou farmácia. Ajudou a fundar jornal. Substituiu o titular do cartório. O casal devia estar feliz. Amélia mostrando ao pai que podia viver como qualquer "mulher direita." Antero escrevendo seu livro de poesia. Um redemoinho veio e varreu tudo... $O$ poeta veio para cá trazido pelo amor. A paixão foi armadilha pra ele? $O$ pensamento morde o pequeno coração. $O$ amor pode ser comparsa do sofrimento? "Próxima Estação...". 
De noite, agitada, a menina dorme mal.

No meio do caminho, Luise tinha a Tita. Praguejada de madrinha. Sem poder namorar. Obrigada a ir para o convento. Entregue às freiras. Ou à desonra inexorável. O pai acreditava. Ela aguardava a hora de partir como noviça. Estudava no Mãe de Deus. Colega de classe da Lídia. A irmã do Auro soube do namoro pelo irmão. Aproximou de Luise. Simpatia recíproca. Na hora do recreio, as cunhadinhas vistas juntas. A Tita descobriu. Luise andava de namorico com o irmão da Lídia.

A menina volta para casa e vê a mãe de longe. Espera parada e de braços cruzados. Cara braba... Por quê? A curta distância, a filha percebe o chicote de couro trançado, dobrado na mão dela. Escuta a pergunta sibilada... "Então tá namorando?" Não responde. "Heim?”. A mãe chega perto. Repete. "Tá namorando?" Luise calada. "Hã?". Na falta de resposta, o chicote... Schlep! Schlep! ...entra em ação. Luise cerra os dentes. "Fala!" O couro canta... Schlep! Schlep! Os vergões crescem. Vermelhos. Ardidos. A mãe insiste. "Responda!". A filha não dá um pio. Joana desconcerta. Luise não se sujeita mais aos seus mandos e desmandos. De repente, tem reação imprevista... "Bate!" Projeta o corpo para frente. "Bate mais!" Desafia. "Bate!” Se mede com a mãe . "Vai!” Joana vacila. Parece cansada. Encara a verdade. Batia em moça feita. Seus braços pendem ao longo do corpo. A filha crescera. Agora é Luise que insiste: "Parou por quê? Vamos, bate! Não para não!" Última surra. A que mais deixa marcas. No corpo os hematomas disfarçados pela blusa de mangas três-quartos sumirão com o tempo. Na lembrança, impinges indeléveis. 
Numa hora dessas, ninguém melhor que a "Coroísta" pra desabafar. A Vó não gosta dela. Diz que é má companhia. Péssima influência. Alguma vez deve ter ouvido a Cora falando aquelas coisas dela... Não tem papas na língua. Diz o quer. Luise chama a amiga e conta tudo para ela, subindo a Rua Cristalina.

- Não aguento mais.

— Que absurdo! Vou te contar viu... Ah, se fosse comigo... Hum! Nem sei do que era capaz... E agora... Vai fazer o quê?

- Não sei... Vontade de fugir... Sonhei que o meu pai veio me salvar.

As duas vão caminhando na direção do Morro das Três Cruzes. Dobram a direita. Contornam o morro. Entram no campo. Plantas miúdas. Árvores médias. Variedade colorida. Espraiada. Luise abre os braços. Ar puro. Perfumado. Alívio. No respiro.

— Adoro o cerrado. Não tem lugar mais bonito. Árvores bem separadas... A gente pode ver tudo ao redor... Caminhar despreocupada.

— E se aparecer algum bicho?

— Ah, dá tempo de fugir... Subir numa árvore... Sei lá. Andei pensando... Morar no mato deve melhor do que aguentar chicotada... Quero experimentar viver como índia. Trouxe até penas.

- Que penas?

Luise tira a capanga de tecido rústico do ombro e saca de dentro algumas penas de galinha.

— Prender com quê?

A menina torna a enfiar a mão no fundo do embornal e retira duas tiras. 
- Você arrancou as faixas do seu vestido azul de bolinha branca... Aquele que a sua madrinha te deu? Quando sua mãe descobrir... Huum!

- O vestido tá velho. Apertado. Rasgado debaixo do braço. Se ela descobrir... Não importa. Eu tô mesmo pensando em fugir de casa, não tô?

- Tá...

- Segura as penas enquanto amarro a tira.

Luise rodeia a testa com o trapo, dá nó cego nas pontas e coloca a pena branca na cabeça.

- Quer que eu amarre a sua?

— Pronto, agora somos duas índias.

- Olha lá!

- O que é aquilo?

- Um cachorro morto.

Chegam perto.

— Ainda não começou a feder...Podemos pegar dentes e fazer colares.

Da fala, a ação. Pegam uma forquilha. Empurram um canino da carcaça.

- Nossa... Como é difícil!

- Deixa tentar.

Apertam e torcem o graveto.

— Não adianta. O dente não sai soltar.

- Se a gente tivesse uma faca, né...

Desistem do adereço dentado e vão caminhando. Plantinhas vergam sob os pés miúdos.

— Olha o pé de estourinhos.

- Carregado. 
Correm para lá. Pegam as vagens. Apertam. Uma a uma. Divertem-se com as explosões minúsculas de ar comprimido. Cloct! Cloct! Não sobra uma no arbusto. As amigas continuam andando. Chegam perto da grota fechada. Folhagem exuberante. Córrego escondido. Debaixo de pedras. Nas locas. Disfarçado.

- Estamos perto do caldeirão.

— Será que um dia as casas vão chegar aqui?

- Não sei... Se acontecer, o caldeirão há de ser protegido... Não acha... Uma praça linda, talvez... Motivo de orgulho pra todo catalanos...

- Até lá, eu não vou estar mais aqui.

- Ah... Cora... Você é tão bem tratada na sua casa... Não leva surra e nem nada... Para com isso.

Mais embaixo, encontram o mesmo fiozinho d'água se exibindo na piscina natural funda e arredondada.

- O caldeirão.

Alcançam o poço. Entram de roupa e tudo. Tomam banho com peixinhos e girinos.

- Meus irmãos pulam do alto da pedra e mergulham na água embaixo, quando a mãe vem lavar roupa aqui.

Ao voltar a lembrar da mãe, o rosto da menina entristece -Sabe... Eu queria ter a força e a coragem da tal Santa Dica...

- Que Santa é essa?

- Quando fui com a Vovó a Formosa, escutei a história dela contada por um "diqueiro". Os seguidores dela são chamados assim. Ficou conhecida porque criou a Cidade dos Anjos... Lugar livre... Tudo dividido entre todos... Terra... Trabalho... Colheita. 
- Como os índios...

— “Como Canudos", disse o homem de Pirenópolis. "Não à-toa, Santa Dica é chamada de 'Antonio Conselheiro de saias. Diz que conquistou "diqueiros" de todas as religiões. Número enorme. Contrariou fazendeiros, políticos, militares, padres... Encantou muitas pessoas também. Morena. Bonita. Moça. Um jornalista foi fazer uma reportagem com a nova "santa", e apaixonou por ela, casaram e tiveram cinco filhos.

- Ah, isso é muito difícil acontecer. A minha família postiça é toda metida em política, você sabe... Em Goiás, o poder que era dos coronéis continua na mão de poucos.

Luise vai contando o que lembra... "O diqueiro" falou que a Dica era sondada por esses partidos todos que rabiscam suas letras nos muros da cidade... PSD... PTB... UDN... Diz ele que ela sabia que usavam o nome dela e deixava o barco correr. Aproveitava a influência que tinha pra ganhar apoio e conseguir benefícios pro povo dela. Por causa dela, o marido chegou a prefeito, eleito pra prefeitura de Pirenópolis, duas vezes. Recebia simpatia disfarçada de muitos políticos... Ludovico... Juscelino...”

- Acabei de lembrar uma coisa, Luise... Não tem muito tempo, ouvi o meu tio falar de uma mulher de Pirenópolis... Só pode ser essa tal santa Dica... Mas, Luise, ninguém ganha o nome "Santa" e comanda um monte de gente sem mais nem menos. O que foi que essa mulher fez pra isso?

— Pois, é... Diz que tinha "visagens". "Conversava" com anjos... "Curava". Desde criança. A fama começou com ela ainda menina "ressuscitando" do caixão logo antes de ser enterrada. O "diqueiro" contou que os moradores antigos falam que, aos sete anos, a garota Dica, a mais velha de oito irmãos, "suou", ao ganhar o "banho de defunto" da igreja católica.

- Curuuuiz...

Luise vai contando para amiga o que o "diqueiro" dissera. "A família não quis enterrar logo. Preferiu velar o corpo por três dias. Alguém falou que ela deve ter tido um ataque que deixa a pessoa como morta. Não foi ouvido. A notícia de que tinha ressuscitado foi se espalhando. Logo o povo dizia que podia curar doentes. A fama atravessou divisas, fronteiras... Lagolândia virou lugar de 
romaria. Gente chegando de todo canto, atrás de cura pra tudo quanto é mal. Foi aí que juntaram o "Santa" ao nome da Dica e ela começou a incomodar. Diz que o Governo ficou com medo da força dela em cima do povo. A Igreja temia que tirasse a atenção dos romeiros de Trindade...

— Iiih... Competição nas peregrinações... Já vi tudo. Trindade, perto da capital, cidade lotada pela maior romaria goiana...

- Santa Dica tinha vinte anos, quando foi acusada de iludir o povo e não pagar impostos. Processada. Condenada. A polícia foi prender. Armada até os dentes. Os soldados cercaram a Lagoa. Os "diqueiros" não arredaram pé. Acreditavam que seriam salvos por um "Exército de Anjos." Dica teria visões “deles". Um teria ensinado ele a ler. Dica mandou os "fiéis" se jogarem no Rio do Peixe. A água ia abrir e dar passagem.

- Que nem o Mar Vermelho... Aqueles que alcançassem a outra margem estariam salvos...

Luise não interrompe a história. "Diz que morreram onze: seis por tiro; cinco por afogamento e a fama de proteção divina cresceu. O seguidor contou como foi o 'Dia do Fogo': Disse que alguns dos que participaram da batalha contam que as balas pegavam no peito dos "diqueiros" e caíam no chão como grãos de milho. Outros, que os anjos desviavam os projéteis. Outros, que Santa Dica enfrentava os tiros e tirava as balas dos cabelos. Presa. Acusações fracas. Não vingaram. Solta no ano seguinte. Precisava ver o orgulho do homem... "Ela é a nossa Joana D’Arc!” Disse que na Revolução dos Paulistas que queriam se separar Santa Dica ajudou a defender a unidade nacional, levando um pelotão de cento e cinquenta homens pra São Paulo, voltando sem baixas e com a patente de Cabo do Exército Nacional. O bando dela ficou conhecido como os "pés-depalhas e pés-sem-palhas”. Ensinava os matutos a marchar, amarrando uma tira de palha no pé de cada um e... "Pé com palha-Pé sem palha-Pé com palha-Pé sem palha...” A marcha saía certinha.

- Mulher esperta e de sorte.

- Acredita que dois escritores escreveram sobre ela? Uma pintora famosa fez um quadro... Um poeta fez uma poesia.

- Mereceu.

— Queria ter pelo menos a metade da força e da coragem... 
- Escuta aqui, Luise... Acha que é só "virar índia" e o problema tá resolvido? Não precisa desse tipo de coragem. Tem força própria. Sou sua amiga e sei disso.

Conversando, conversando... As amigas, distraídas... O dia voa. O sol esconde. Começa a escurecer. O frio faz tiritar. A fome chega para valer. Não é hora mais de pensar em fuga. Acaba a vontade de ser índia. Melhor voltar antes que a noite caia de vez. Penas e tiaras molhadas, largadas em cima das pedras.

$\mathrm{Na}$ volta, as meninas conversando - Sabe, Luise, o meu negócio não é índio e nem santo... Mas admiro a pessoa que sabe ir atrás do que quer... Já ouviu falar da Lagoinha do Paquetá?

- Não.

Cora Alice vai contando sobre o "Lugar lindo! Perto do aeroporto. A mata fechada escondia um tesouro: animaizinhos silvestres, garças alvas, marrecos, lago cheio de peixinhos, fartura d'água." A descrição faz Luise lembrar a viagem que fizera com a avó, pelo sertão... Posso imaginar direitinho... Conheço lugar assim. “...pequeno povoado debaixo de árvores, poucas casinhas de taipa e sapê, só um casarão com alpendre, vidraças, cobertura de telha. A dona da Lagoinha sabia defender seu patrimônio com zelo. Não deixava danificar. Não tolerava nenhum tipo de agressão. Ai de quem ousasse depredar!” Luise figura a mulher com fama de valentona, que portava revólver de doze tiros e metia medo. "Tinha experiência. Foi dona do 'Chalé da Marcelina', uma casa de mulheres, na antiga Praça Uberlândia. Não perdia tempo. Cuidava bem do seu negócio. Juntou bom dinheiro. Comprou a estância da Logoinha. Fez pousada do casarão. Montou bar. Servia doces, salgados, bebidas, pratos feitos... Café servido com açúcar de primeira. Bolo de cidrão. Queijo do melhor... Cativava os viajantes. Com a ajuda das suas mulheres. Principalmente os cavaleiros, carreiros que vinham da zona rural, transportando cereais para comercializar na cidade. Pra você ter ideia... Um jagunço, que andou pelo grande sertão de Goiás e tem sua história contada em 
livro famoso no mundo inteiro, escrito pelo amigo do Agel, conta que pousou lá uma vez: 'Cheguei e logo achei que tal lugar devia era ter nome de Paraíso'. No interior da época, nem automóveis, nem caminhões, nem rodovias... Os animais pastavam soltos e livres no enorme capinzal verde. Os viajantes dormiam no casarão. As tralhas guardadas num ranchão de sapé. Pagavam aluguel de tudo: rancho, pastos, companheira se quisessem. Diante de qualquer confusão, o revólver de doze tiros falava alto. Marcelina comandava o lugar junto com sua irmã, Ritinha. Diz que as duas eram bonitas... Marcelina branquinha e dengosa; Ritinha morena e beicinho de pitanga. Ricas... dinheiro, terras e roças. Respeitadas... Vindas de boas famílias. Tinham traquejo. De noite, a casa alumiada para admitir os viajantes. A estalagem era ponto de pernoite com altas pagas. Recomendada pros que quisessem coisa boa, a pousada ganhou fama. Depois a Marcelina começou a namorar um ferroviário da Mogiana, e o lugar passou a ser conhecido como 'Pousada da Mogiana'.

Um dia, o Zé Periquito cruzou com a Marcelina, numa rua, aqui em Catalão. Ele tinha sido impedido, uma vez, de entrar no chalé da Praça Uberlândia e era implicado dela. Querendo aproveitar a oportunidade pra fazer uma provocação, colocou dois dedos na boca, deu assobio forte e imitou o apito do trem. Não satisfeito, o gaiato ainda virou pra mulher e mandou essa: “A Mogiana apitou!” A Marcelina, enfiou a mão na saia comprida e rodada, sacou o revólver e respondeu: "E apitou mesmo!" Ao mesmo tempo, que disparava. Ela deu quatro tiros em volta dos pés do Periquito, que voou pela rua afora e sumiu. Mulheres valentes assim, eu admiro. Aqui, tem a Mádima, que a gente conhece, e o povo respeita, mesmo rindo dela. Casou três vezes. Maridos sempre mais moços. Mãe de vários filhos. Homem nenhum manda nela. Diz que quando enjoa, mata e arranja logo outro, atraindo com dinheiro..."

As meninas andam depressa e logo se despendem, cada qual caminhando no rumo da própria casa. Luise chega ressabiada. Sem vontade e nem coragem para entrar. "Onde você tava? Entra, vamos!" A boa sorte trouxera a avó de volta de Goiandira... "Pro banho. Depressa! Sua mãe deu um pulinho até a casa Dinda pra benzer o Elcio e vai voltar logo.” Escutando a aventura, Vó Mina ajuda a neta a se livrar dos troféus: carrapicho, picão e carrapato. 
Luise volta a encontrar a irmã do namorado na hora do recreio. Ela está a par do que aconteceu. A Tita fizera questão de contar. Lídia quer confirmação. Saber mais. Desde o início, aproximara-se da namoradinha do seu irmão... Gentil... Carinhosa até... Chamando de cunhadinha e tudo... A reservada Luise confia. Levanta as mangas do uniforme. Expõe as manchas roxas enormes. Lidia se mostra condoída. Solidária. Despedem-se no fim do recreio. Muito sérias. Poucos dias depois, Lidia traz para Luise o bilhete. Dele! A menina abre quando está sozinha. Não acredita no que lê... Soube o que aconteceu com você e como sou ainda muito novo para levá-la a esse sacrifício, é melhor terminar. No papel aberto, diante dos seus olhos, as letras tremem... embaralham... desaparecem fundidas no borrão azul...

Em casa, no quarto, deitada, dentes cerrados... Não pareciam palavras dele. Alguém ajudou a escolher? A irmã... A mãe... Será? Não sei de mais nada. Uma réstia de luz desce do teto, mas parece brotar do chão. Corta a escuridão em diagonal e expõe milhares de partículas de poeira, suspensa, pairando no ar. Do mesmo modo, Luise, pulverizada. Solta. Aérea. Desintegrada. Como poderia saber que não estava num sonho? Sempre alguém gosta de alguém... Que gosta de outro alguém... Que gosta de outro alguém... Difícil, dois gostarem um do outro ao mesmo tempo. Aconteceu. Aconteceu?

Luise espera o domingo. A semana custando a passar. Nunca demorou tanto. Na porta do cinema, inquieta. Olha de um lado para o outro... O Auro não apareceu. Passa outra semana. A menina lá. Mesmo horário. Mesmo lugar. Espera a voz querida... Única... Soprar em seu ouvido o pedido para guardar lugar. $\mathrm{Na}$ outra. Na outra. Queria tanto saber dele. O sofrimento transparece. Na expressão séria. No rosto desfeito. Não tem como ficar escondido. Não quer 
perguntar para a Lídia. Conversam pouco agora. Só um cumprimento aqui e outro ali. Preciso seguir em frente. Tem a ideia de mandar o caderno de questionário amoroso para o Menino responder. Faz isso. Espera uma semana até chegar de volta. Aflita, quer ver as respostas. Segura a ansiedade. Espera para ler sozinha. Caderno debaixo de braço. Para casa. Rápido. Abre a capa. Dedos trêmulos. Coração aos saltos. Será que ele respondeu? Faz correr a primeira folha pela espiral. Está lá. Letra firme. Completo. Por extenso. O nome dele. No número correspondente. Vira as folhas. Lê as respostas. Uma por uma. Certo cheiro exala? Perturba. Reaviva a lembrança. Música de filme. Entrelaçamento de mãos. Escurinho do cinema. Quer e não quer chegar à última pergunta. A principal. Receia. Não resiste mais. Passa a folha. Na primeira linha. A caligrafia caprichada de Luise faz a pergunta: "O que você acha da dona deste caderno?" Desce a vista. Lê a resposta. "Dispensa comentários." O coração parece encolher. Dispensa comentários?! Isso não quer dizer nada! Nada! Dispensa comentários... Para escrever isso nem precisava ter preenchido... Por que concordou? Esperei tanto-tanto.

Luise é pura decepção. De longe, a mãe observa. Um dia surpreende. "Eu me informei sobre o Auro... Soube que é de boa família... Bla-bla-bla... Pode continuar o namoro". A menina não se dá ao trabalho de responder. Mesmo que quisesse não poderia. Por causa da dor. Não uma dor qualquer.

Luise vai às vezes, à casa do Sr. Cornélio assistir aos calouros que ensaiam nas tardes de sábado para cantar na Rádio Cultura aos domingos. Gosta de ouvir histórias e poesias contadas pelo dono da casa. Muitas verdadeiras. "Casos que aconteceram numa Catalão de outros tempos", como ele mesmo diz. Neste dia, a menina vai lá, para se distrair, e dá sorte. O Sr. Cornélio espera o rapaz da "Rádio Cultura” chegar para dar início ao ensaio, falando sobre Bernardo Guimarães. “...exerceu o cargo de juiz, em duas ocasiões. Na primeira judicatura ficou dois anos, decidindo sobre questões de órfãos e heranças. Na segunda, chegou aqui 
com o ambiente tenso por causa da fuga de alguns presos e a deserção dos soldados que os ajudaram na escapada. Logo que tomou posse promoveu um polêmico júri sumário e libertou o restante... 'por delitos de pouco importância e pessimamente instalados'. Entrou em conflito político com o presidente da província. Catalão fazia parte da comarca do Paranaíba. Bernardo, Juiz Municipal e Virgínio Henrique Costa, Juiz de Direito". A menina fica admirada vendo o Sr. Cornélio, sempre discreto, andando agora de um lado para o outro e gesticulando energicamente diante da jovem plateia... Noossa... Que animação... Deve ser porque é poeta também. "Acusado de usar o alto cargo para cometer arbitrariedades, pelos cidadãos, Antonio da Silva Paranhos, Francisco Manoel de Cássia, José Ferreira de Gouveia Guerra e Antonio Pedro de Melo, Virgínio reagiu, processou os quatro e Bernardo impronunciou todos". Chaaap! Comprou briga. "O Juiz de Direito se voltou contra o Juiz Municipal, baseado em denúncia anônima e apoiado pelo Presidente da Província. Bernardo acabou enquadrado por irregularidade de conduta, acusado de mandar soltar quatro presos e ter vida irregular morando com uma mulata. O escritor relatava os acontecimentos, mandava os artigos para o Rio de Janeiro e o amigo Flavio Farnese publicava no jornal "Actualidade". Os escritos, de valor literário reconhecido, eram reproduzidos por outros jornais. A briga dos juízes deliciava os leitores da Corte. Fazia sorrir bocas nobres. Dava realce a prosaica Catalão. Por ocasião do seu julgamento, Bernardo lavrou a defesa de próprio punho. Peça preciosa. Teor mais literário do que jurídico. Vale a pena ser ouvida." O poeta limpa a garganta e começa a leitura: “O denunciante, não contente em esmerilhar a vida pública do Juiz e de lançar mão de quanta futilidade que lançou mão para vexá-lo com acusações infundadas e irrisórias, ainda vai com mão profana..." Profana... palavra muito estranha... $\mathrm{O}$ dono da casa faz breve pausa, ajusta os óculos e continua lendo, em tom de voz solene, o que Bernardo escrevera... "Solteiro... na alegria dos festins...” Luise se esforça para prestar atenção. Entende uma frase, uma palavra... Festim vem de festa... Então... Na alegria das festas “...ama os prazeres da música e do vinho, a dança..." A música e a dança alegram muito a vida... Vinho também deve ser bom... O padre gosta tanto. “...o próprio denunciante, se não é algum anacoreta...” $\mathbf{A h}$, isso só pode ser xingamento. “...sujeito a essas pequenas fraquezas da humanidade?” Pedra no telhado do outro? "Bernardo era estimado. Cultivava amizade com as famílias mais 
importantes. Foi impronunciado na sentença proferida pelo Juiz de Direito substituto, Manoel Pereira de Cerqueira, um dos mais antigos troncos da família Netto. O juiz-escrito saiu triunfante. Sua carreira, comprometida".

Sem disfarçar sua admiração pelo escritor, o Sr. Cornélio fala agora do poeta, numa linguagem que a menina consegue entender melhor. "Bernardo tinha a habilidade de conviver bem com qualquer pessoa. Não importava o meio social a que pertencesse. Relacionava-se com pessoas respeitáveis e, com a mesma facilidade, misturava-se com boêmios, bêbados, pobres, roceiros, jagunços, injustiçados, mulheres livres. Um talento quase mágico para brincadeiras e ditos. Apreciava uma boa cachacinha. Contam que certa vez, no exercício do cargo de delegado de polícia, acenou para um caipira que passava no seu 'rosilho', o homenzinho, receoso da justiça, quis escapar trotando o cavalo e só a custo Bernardo conseguiu detê-lo... 'Ôooa... Quero ver o que tem dentro desse guampo de chifre, preso na cabeça do arreio'. A intenção era apenas pilhar um pouco da boa pinga do matuto". Deve ter sido engraçado, o roceiro tentando manejar o cabresto pra escapar, e o juiz pendurado no arreio. "Bernardo passou um mês inteiro pescando, caçando, bebendo cachaça ao lado do índio João Afonso e seus comparsas às margens do Paranaíba”. Luise atenta ao relato... Aqui era terra de caiapós, carijós, araxás, cariris... De qual tribo esse índio terá vindo? "Chefiava a parentela a serviço de chefes políticos do tempo da monarquia. Agia no sudeste goiano, no triângulo mineiro e no alto Paranaíba. Morava à beira rio. Participou das lutas ferozes entre Ayres e Paranhos”. Conheço alguns Ayres e Paranhos... Que lutas terão sido essas? "O índio Afonso, às vezes, depois de um "serviço", lavava o sangue da faca comprida, a vista de todos, num corguinho da praça da velha matriz, montava no cavalo e ia embora calmamente. Descendente de índio, mulato alto, fala macia, maneira respeitosa de tratar as pessoas...". Pra ser valentão nem sempre é preciso mostrar ruindade de cara. "Bernardo escutava as histórias e aventuras dos crimes que o facínora cometia, anotando tudo. Um dia, interrompeu a narrativa do temido aventureiro: 'Afonso, tu não és criminoso, és um herói!' Da conversa, nasceu $O$ Índio Afonso. Catalão, cenário. Gonçalo, o personagem principal de outro livro notável do romancista, $O$ Ermitão de Muquém, ambientado no Estado de Goiás, é tido como o fundador da Romaria de Muquém." 
— E o Fagundes Varela, Sr Cornélio?

- Luiz Nicolau Fagundes Varela... Sabemos pouco da passagem dele por aqui. Era muito criança quando morou na casa que futuramente Bernardo viria ocupar como nosso terceiro Juiz de Direito. Ao contrário do Vate de Minas, não teve tempo de deixar marca para vinculá-lo à história da terra.

- Ficou por dois anos

— De 1851 a 1853. Filho do Dr. Emiliano Fagundes Varela, nomeado Juiz de Direito da comarca Meia Ponte, atual Pirenópolis, logo que foi criada. Fixou residência em Catalão, talvez por ser mais perto da divisa com Minas Gerais.

Breve resposta e não hesita em voltar a falar do que quer. "Bernardo gostava de trilhar as estradas sertanejas. Pousar nos ranchos. Escutar a viola à beira do fogo e histórias do tempo antigo. $\mathrm{Na}$ tarde em que recebeu a notícia do falecimento de Álvares de Azevedo no Rio de Janeiro, ele estava aqui em Catalão e passou a noite compondo um poema longo em homenagem ao amigo morto. Mandou para o Jornal do Comércio, na Corte. Não foi publicado."

- Por quê?

— Não se sabe.

"Morte do amigo. Malograda a ideia de tocar adiante a publicação da antologia com trabalhos de Bernardo Guimarães, Alvares de Azevedo e Aureliano Lessa, companheiros inseparáveis, quando estudavam em São Paulo. Fim da chance para As três liras? Bernardo então se lembrou de alguns rascunhos de versos e originais escritos por Álvares para a antologia." De novo a palavra... Antologia. Luise olha ao redor... Caras sérias... Será que tão entendendo tudo? Ou quase nada... Como eu... "Estavam num baú. Esquecido no quarto da Rua dos Bambus em São Paulo. Escreveu para Hilário Gomes de Castro e pediu que mandasse os papéis. Recebeu recado de que as Vidais, na casa das quais tinha morado, tinham posto fogo em tudo, 'num acesso de higiene". Luise imagina as línguas de fogo devorando os versos e as palavras se retorcendo... Perdidas para sempre... Ai, que pena! "Bom músico, excelente poeta sendo o violão seu instrumento de preferência, sempre rodeado de amigos, pessoas de destaque nos meios culturais. Catalão ouviu suas primeiras serenatas, executadas por Bernardo 
e Roquinho". Quando os dois poetas começaram com as serenatas românticas na cidade, adentravam as noites catalanas versejando ilusões desfeitas, amores impossíveis, romances destruídos... Ah, quanto coração chorou a saudade do passado, na música ritmada dos acordes sonoros das serenatas, com suas estrofes poéticas... Bernardo era o mestre do improviso. Mas não conseguia guardar os números musicais de memória. Não podia recompor. Não tinha como voltar a executar. Puxa... Não anotava... Devia... Como fez com as histórias do Indio Afonso... "Diz que chegou a Catalão sem ter gasto vintém na viagem. De fazenda em fazenda, pagando a hospedagem com o poder criador do seu verbo. Cada fazendeiro que o hospedava se encarregava de mandá-lo aos mais. Li em algum lugar que "Bernardo era um Byroniano como poucos". Ai-ai... Quando o Sr. Cornélio se empolga assim... "Se Byron atravessara os Dardanelos para passar a noite com a amada na Turquia asiática, o poeta, estivesse o Paranaíba calmo ou revolto, atravessava a divisa a nado para dormir em Minas Gerais”. Dardanelos... Turquia asiática... Misturado com o Paranaíba... Agora é que eu não entendo nada mesmo! "Mesmo o barqueiro Cirino estando lá, à beira do rio, com a canoa, pronto a servi-lo. Bernardo falando de Cirino: 'De bom grado eu o compararei a Caronte, barqueiro do Averno, se as ondas turbulentas e ruidosas do Paranaíba, que vão quebrando o silêncio dessas risonhas solidões cobertas da mais luxuriante vegetação, pudessem ser comparadas às águas silenciosas e letárgicas do Aqueronte." Nas passagens do discurso que menos compreende Luise é cativada pela variação do som... Cada palavra tem sua música... Uma é mais forte... Outra mais fraca... Varia.

O Gercílio entra. O ensaio vai começar. Luise desiste de assistir. Sai de fininho. Pelas caras ao redor... Parece que ninguém entendeu quase nada... Como eu. Onde o Sr. Cornélio tá com a cabeça? Acho que esqueceu pra quem tava falando... Diz que quem lê muito fica de miolo mole.... Será? Ai, meu Deus... Gosto tanto de ler... O que vai ser de mim? 
Luise gosta mesmo de um bom livro. A Lena fez inscrição na Biblioteca Municipal. Costuma pegar mais de um por vez. Aproveito e leio também. Leu A Cidadela e sofreu com o jovem médico idealista, que acabou se deixando corromper. Leu Clarissa e se encantou, viajando com ela pelas ruas de Porto Alegre. Quero ler tudo de Érico Veríssimo. Li Éramos Seis, Como era verde o meu vale. Nem tudo é perfeito. A menina precisa gastar tempo, estudando álgebra. Ainda bem que a Irmã Carmélia explica bem. Ela gosta da escola... É bom estudar canto com a Irmã Maria... Jogar vôlei... Aprende sem dificuldade. Recebeu até um elogio pela boa redação, lida em sala de aula. Faz novas amizades... Edna, Carolina... Passou facilmente do quinto ano para a primeira série ginasial. Preciso ler Bernardo... Escreveu sobre a nossa cidade... Demaaais! Muita gente importante passou por Catalão. Luise tem interesse em conhecer a história do lugar onde nasceu... Depois da bandeira do Anhanguera, passou muito tempo sem ninguém saber o que aconteceu. $O$ fio do boca a boca rompido. Nenhum registro sobre a fazenda do padre espanhol. A menina imagina uma cortina escura e pesada de silêncio, abafando o sítio. Começa a prestar atenção e a tomar nota de certas frases históricas, pinçando uma aqui... “É certo que o povoado já existia em 1736”. Outra ali... "O território goiano pertencia à capitania de São Paulo, documentos, daquele ano, mencionam duas ocorrências no povoado de Catalão. A primeira, a passagem do governador D. Antonio Luiz de Távora e a vinda do Conde Sarzedas a Goiás para a entrega do remontante dos direitos da cobrança das minas a Bernardo Fernandes Guimarães. A segunda, o assassinato do Capitão José Morais de Toledo Cabral, morto por Domingos do Prado, genro do Bartolomeu Bueno da Silva, "por desavença, conforme relatado pelo Padre Luís Antonio da Silva e Souza”. Coisa horrível... A morte servindo de prova de que o lugar existia... Cruz credo! Anotando as especulações... "Perto do Córrego do Almoço, o pouso de Catalão acolhia as bandeiras que passaram pela região". "A Sesmaria do Ribeirão, nas nascentes do Pirapitinga". "A fazenda do Catalão na Grota, direção Córrego do Almoço." Registrando relatos orais que, a partir de 1808, com a chegada da família real ao Brasil, recomeçaram a circular. "Viajantes descreveram o vilarejo 
com menos de uma dúzia de casas de telha e alguns ranchos de palha". "O povoado surgiu entre os três cursos d'água: o Córrego do Almoço, o Ribeirão Pirapitinga e o riacho que corre ora sob a grota e ora sobre as pedras...”. O riacho do “Caldeirão..." Só pode ser! Cheio de peixinhos... girinos... Eta lugar bom pra tomar banho! Os meninos saltam do alto das pedras, sem medo... Eu entro sem pular. A menina vai fazendo recolha dos fragmentos que interessa... "As primeiras casinhas de taipa e adobe, estilo português, subindo emparelhadas aos ranchos de capim." Traça a geografia do seu jeito... Por isso, Rua da Grota, Bairro da Grota e, não à-toa, o povo pela vida, repetindo: "Quem vem a Catalão e bebe água da Rua da Grota, vai, mas volta". "As primeiras fazendas do município vieram com o sistema de concessão de terras no Brasil. Em 1840, cem anos depois do Anhanguera, Catalão contava 500 habitantes." Crescendo devagar e na calada. "A exploração do ouro diminuiu”. "A agropecuária passou a ser verdadeiro ouro". "Havia pessoas carregadas do metal que passavam fome, por não terem onde encontrar mantimentos".

"A pequena igreja, erguida num plano elevado, a hoje conhecida Velha Matriz, singela, torre única, erguida no meio do terreno, olhando para as primeiras casinhas. A cidade cresceu atrás dela e agora... Nossa Dama do cerrado dá agora as costas pra ela.

$\mathrm{Na}$ aula de história, livro aberto sobre a carteira, Luise acompanha leitura... "O governo português passou a se interessar pela agricultura e pela criação de gado". Seleciona trechos... "Tirava vantagem do sistema de sesmaria para povoar o território e recompensar nobres, militares e navegadores por serviços prestados à coroa portuguesa." Copia as passagens que interessa. "As terras eram doadas para pessoas de confiança da realeza portuguesa". O 'dando que se recebe' de $S$. Francisco aqui também... Muitos ex-sesmeiros e descendentes tornando-se fazendeiros na região. As fazendas tomando impulso. Catalão, sede do município enorme, abarcava vários distritos. No período regencial, na intenção de proteger o Império e o Imperador menino, o Padre Diogo Feijó fundou a 'Guarda Nacional', estrategicamente criada para manter a fidelidade das elites no interior e reforçar a unidade do país. Congregou os homens no corpo único da "sentinela da constituição jurada”. Patentes e cargos honoríficos foram concedidos aos homens de projeção. O nome seguia para o Rio de Janeiro, e a decisão vinha, 
depois, com a investidura mediante o pagamento da importância correspondente à patente indicada pelo chefe político de prestígio com o governo.

Fazendo sua colagem das especulações, relatos e fatos históricos, do seu jeito, a menina vai tirando conclusões próprias. O padre não era bobo... inventou jeito de vender nomes pros vaidosos, pegar o dinheiro deles e ganhar o apoio que precisava. Ai-ai... Tem muita gente esperta nesse mundo... Terras eram cedidas a quem tinha condições financeiras de explorá-la. Roque Alves da Silva chegou a Catalão, 'Coronel' Roque. Tomou posse de grandes extensões. Descrito por Francis de la Porte, Conde de Castelnau, como “muito magro, alto, tinha pernas longas e finas, como as de uma aranha... Já pensou se esse Coronel soubesse que conde ia descrever a figura dele desse jeito e todo mundo ia poder ler? Castelnau, enviado pelo governo francês ao Brasil, aportou no Brasil, chefiando uma expedição científica, formada por um geólogo, um médico botânico e um funcionário do Museu de História Natural de Paris. A expedição saiu do Rio de Janeiro, acrescida de escravos e tropeiros contratados, atravessou o Paranaíba, entrou em Goiás e chegou a Catalão, com o conde, trazendo uma carta de recomendação para o 'Coronel' Roque. Toda essa gente importante que vem a Goiás entra por Catalão... $O$ conde e os cientistas foram recebidos e hospedados, pelo 'Coronel', com a maior cordialidade. A comitiva ficou dez dias. O anfitrião fazendo tudo para agradar. O 'Coronel' Roque não tinha filho e adotou um recém-nascido. $O$ menino foi batizado com seu próprio nome e passou a ser chamado de Roquinho”. Olha só! Castelnau saiu da Vila de Catalão, desceu pelo rio Araguaia e subiu pelo Tocantins, fazendo minucioso estudo descritivo da região: população, história e comércio. Ficou quatro anos aqui em Goiás?!

As terras atraiam. O município de Catalão era famoso pela riqueza e vastidão dos terrenos. Poucos conflitos. Menos por posse do que por demarcação e acesso à água. Escutando certas frases, Luise levanta a cabeça e estica o pescoço. “O Major Manoel Pereira de Cerqueira veio de Poços de Caldas trazendo a família para tomar posse do quinhão da Sesmaria do Ribeirão. A mulher dele era irmã do Marquez do Paraná... Então foi ganhando as terras que os Cerqueira chegaram aqui... A dificuldade na lida com terrenos cansados trazia pessoas dispostas a se embrenhar pelo sertão, buscando lugares cobertos de matas para 
derrubar. Plantar roças. Criar gado. Fazer açúcar. Pinga. Vinha muita gente de Minas Gerais. Os Martins vieram com a mudança normal transportada em carro de boi, e de máquinas de engenho de cana, também, trazendo tachos, tanques de madeira, engenho, alambique e outros apetrechos. Dias e dias na estrada. Direção, o morro arredondado. Década de 1930-40, fazendas com engenhos de açúcar como a Fazenda Morro Agudo. Antonio da Silva Paranhos veio de Paracatu pra Catalão, montou armazém de secos e molhados, sortido com mercadoria que trazia de São Paulo e do Rio de Janeiro, nos lombos das suas tropas de burro...

Luise escuta-anota-reúne-lê-reflete... Ela tem a memória povoada pelas imagens das histórias do Sr. Cornélio... "Com a chegada do padre a cidadezinha goiana juntou, de repente, na mesma ocasião, por diferentes motivos, quatro intelectuais habituados à vida das grandes cidades: o deputado Antonio da Silva Paranhos, do Rio de Janeiro, parente do Visconde do Rio Branco;" Diz que esse tinha até uma liteira... "O poeta Roque Alves de Azevedo, que estudou no Colégio Caraça de Minas Gerais; o Juiz Bernardo Guimarães que estudou em São Paulo; o cônego Luiz Antonio da Costa. O anfitrião, português culto, apreciador das belas-letras, franqueou a casa ao bardo e proporcionou hospedagem generosa enquanto ele esteve ali. Mandava realizar ceias e danças, a quadrilha marcada em francês, o cotilhão, o minueto, a gavota...”. O conhecimento recente mistura-se com o material das imagens retidas na memória da menina e molda novo corpo. Atualiza a colagem. Ao seu modo. Posso ver o escritor Bernardo Guimarães, nomeado Juiz de Catalão, muito bem recebido pelo Deputado Antonio Paranhos, rindo... ceando... brincando... no salão enorme da sua casa bem ali no canto do jardim. Bernardo, amigo do poeta Roquinho filho postiço de Roque um homem "muito magro, alto, pernas longas e finas, como as de uma aranha" que, decerto, pagou dinheirão pra ter o título do 'Coronel'. Começaram as poesias e as rondas de serenatas... Os quatros rapazes tocando, cantando, pelas ruas da cidade... Não devia faltar inspiração. O fresquinho do planalto... O céu ora coalhado de estrelas... Ora alumiado pela luona daqui... Demaaais! Será que o encontro deles foi por acaso... Ou tinha que acontecer mesmo? Devia ser bem divertido ver o escritor, o padre e o boticário entrando nas brincadeiras, participando das rodadas de "voltarete 
e da vermelhinha" ${ }^{12}$ Mas, parece que a vida é também Penélope, no seu faz e desfaz. O Sr. Cornélio também disse "as coisas mudaram. O Deputado Paranhos casou com D. Belizária de Paracatu... Roquinho morreu solteiro... Bernardo foi embora... Quando voltou, pela segunda vez, conheceu a mulata, apelidou de Jequitiranaboia e levou pra casa. O padre Luiz Antonio se uniu à Maria Cristina Rodrigues da Cunha e constituiu respeitável família”. Ai-ai... Como entender essa confusão... Casar não pode... Arranjar família pode? “Quatro filhos: duas meninas e dois meninos. 'Os filhos do vigário' cresceram. Deram gosto aos pais. Uma filha casou com um rapaz da família Netto, outra com um moço da família Paranhos. Um filho casou com uma Pimentel, outro morreu solteiro." O que é certo o que é errado? Ensinam de um jeito, fazem de outro e tudo fica como certo? Pra que servem as regras? Valem pra quem? Não sei de mais nada. O Sr. Cornélio disse que um neto do padre foi deputado federal e se candidatou ao governo estadual na eleição 1954. "Perdeu porque foi esbulhado numa tendenciosa demanda jurídica na qual conseguiu sair vitorioso depois do término o mandato do opositor". $\mathbf{E}$ diz por aí que antes de formar lar com a moça catalana "de ótima família", mãe dos "quatro filhos do vigário", o padre andou enrabichado com uma tal Caetaninha do Rio Verde...

Catalão elevada à cidade em 1835. Sede de município enorme. 18.000 quilômetros quadrados. Abarcando vários distritos: Goiandira, Ouvidor, Três Ranchos, Davinópolis, Santo Antonio do Rio Verde... Este, um povoado estratégico para os comerciantes de gado que saindo de Formosa, em Goiás, ou de Paracatu, em Minas Gerais, acompanhavam suas boiadas na subida para Barretos, em São Paulo. Rio Verde, passagem obrigatória, na ida e na volta. Pousada. Pernoite. O vigário Luiz Antonio dava assistência aos distritos. Celebrava

\footnotetext{
${ }^{12}$ Voltarete: 3 cartas, baralho de 40 cartas, três parceiros, cada um iniciando com 9 cartas. Vermelhinha o dono do jogo mostra 3 cartas, vira para baixo, muda a posição, e a vítima tenta acertar qual é a vermelha.
} 
batizados. Fazia casamentos. Aconselhava e orientava paroquianos... Huum... Logo quem! ...viajando daqui pra lá e de lá pra cá, com o sacristão, Pedro Lira. As primeiras sextas-feiras de cada mês reservadas para Rio Verde. Hospedava-se na pensão do viúvo Caetano, sempre jogando cartas ou negociando gado e largando a pensão por conta da filha Ernestina, a "Caetaninha”. Jovem. Bonita. Namoradeira. Insinuante. Sedutora. Atraía freguesia selecionada, nas barbas de Severino, namorado firme, fazendo vista grossa. Fora da igreja, o padre Luiz Antonio usufruía da companhia de mulheres, sempre que podia. Em Rio Verde, despendia o tempo de folga com a Caetaninha. Não sabia com quem tava se metendo... Nas repetidas viagens, aprofundou relacionamento com a jovem pensionista. Grávida, o vigário se afastou do vilarejo. O casamento dela com Severino, apressado. Nasceu o filho batizado Urias. Bem aceito pelo marido. O casal veio a ter mais três. Sob os olhos do complacente marido, a ardilosa Caetaninha jogando com a sorte. Aliciava comerciantes. Seduzia fazendeiros. Conquistava velhos coronéis da política. Vestida com luxo. Esnobando riqueza. Exagerando no uso das joias: brincos, anéis, pulseiras, colares de contas enormes. A comunidade comentava. "A Caetaninha tá de pescoço torto com o peso de tanto adorno". Avaliava. "Tudo de ouro". O tempo passou. O pai morreu. O marido não existia. Os amigos sumiram. Caetaninha envelheceu. Apelou para a violência. Usava os quatro filhos para praticar delitos e intimidar amantes antigos. Urias, o mais temido. Reforçava o grupo de vez em quando, com jagunços frios e obedientes. Procópio, o pistoleiro preferido. O mantimento diminuindo? A mulher não se apertava. Recado para um fazendeiro das relações antigas: "Minha despensa está vazia, mande alguma coisa já.” Logo, um carro de boi rabeava na porta do seu casarão, descarregava capado gordo, saco de arroz, feijão, milho... Senão... Um morto aparecia logo na beira da estrada. Cabeças de vaca sumiam. Desapareciam comerciantes, vindos de Barretos a caminho de Formosa, com o dinheiro da venda do gado. Medo. Desassossego. Mistério. Ninguém tinha coragem para enfrentar a Caetaninha suspeita. Desfecho de uma tentativa, da polícia de Catalão, contado assim:

O delegado espantado recebeu das mãos do jagunço um embrulho manchado de sangue e indagou: 
-O que é isso, Procópio?

- É as farda dos sordado que vossamecê mandô pa prendê a Sinhazinha...Eles ficaro enterrado sem ropa lá mesmo no arraiá.

Protesto unânime: "Nós ou ela!” O corpo de Jerônimo Có-có apareceu varado de balas de carabina no caminho da sua fazenda e Davi Có-có, seu irmão, decidiu que era hora de dar um basta aos desatinos da mulher capaz de qualquer coisa quando contrariada. Quis organizar os moradores da região e invadir o casarão de vez. Foi aconselhado a ter prudência. Partiu para a capital Goiás, munido de recomendações escritas por políticos influentes, para pedir providências. Aproveitou e alardeou "consequências funestas" caso o povo se amotinasse. Uma escolta enviada a Catalão. Seguiu para o distrito, orientada. Acompanhada por Davi Co-có. Caetaninha de tudo avisada pelos espiões. Reforçou a guarda. Permaneceu na casa trancada com três filhos - o quarto viajando - e mais alguns jagunços bem armados. Os militares chegaram e cercaram o casarão. A mulher intimada a se entregar sem resistir. Não quis conversa. Tentativa de invasão. Tiroteio cerrado. Urias, o filho dileto, atingido. Morto. O desespero da mãe. O lenço branco acenado. A distração momentânea do comandante na mira das carabinas. Alvejado mortalmente. Vítima da simulação. A gargalhada feminina! O palavrão na boca da mulher! O cerco feroz. A invasão. O extermínio. Osório, o neto de dois anos de Caetaninha, escapando. Duas vezes: dos tiros e das ameaças de ser jogado para o alto para ser aparado a ponta de sabre... "Pra acabá com a raça de veiz". O menino arrancado das mãos da soldadesca, no último minuto, salvo por um soldado mais moderado. Fim do massacre. Dentro da casa, arca lotada: rifles, mosquetes, carabinas, arcabuzes, revólveres, garruchas, espadas, facas, punhais... Encontradas, entre as armas, as dos três soldados sacrificados na diligência anterior. Anos mais tarde, casarão demolido. Ossadas achadas pelos escavadores. Os mais antigos dizendo que eram restos das pessoas misteriosamente desaparecidas, executadas no interior da velha morada, sepultadas no porão. 
Com o dia do seu aniversário chegando, Luise não quer perder a oportunidade de tentar uma reaproximação do Auro. Convida os amigos para uma brincadeira de "a direita está vaga". Na porta da casa dela. À noitinha. Será que ele vem? Na véspera, recebe um recado. Fica ansiosa. Dá tempo de pedir ajuda para a Marta e a Lena. Sugerem "pudim de leite condensado, a maior novidade." Ensinam a preparar. Luise serve para a D. Judith e Lídia, que mandaram avisar antes que iam passar de tarde para cumprimentar. Trouxeram presente delicado. Pequeno coração pendurado num cordãozinho de ouro. Dão a entender que o Menino mandou. Luise lê a inscrição' Deus te guie.' Que dor! De noite, cadeiras na porta. Amigos reunidos. A brincadeira durando até tarde. Alguém dizendo ser pena o Auro não ter vindo para ver Luise de vestido novo. Ela mesma fizera. O verde realça a cor dos olhos. De vez em quando, o brilho raso transborda. Será que a gente pode gostar de outra pessoa do jeito que gosta da primeira? Fim de semana com gosto de lágrimas.

$\mathrm{Na}$ segunda feira, Luise entra na confeitaria da avenida, compra um picolé de coco queimado e sai lambendo... Gosto de caminhar devagar por essa avenida. Já foi conhecida como Rua Direita... Rua do Comércio... Gosto de Avenida Goiânia... Será que um dia vão mudar o nome dela de novo? A farmácia... firme, forte, reformada... A prova de amor tá aí, de pé, depois de tantos anos. 1858. Chico Manco montou a botica. Um ano antes de Catalão passar a cidade, a data não é difícil guardar. Raptou D. Dadinha pra casar. Levou um tiro dos Silveira parentes dela. Ficou aleijado. Ganhou o apelido “Manco". Não se importou. Sentiu orgulho até. Diz que usava a alcunha até pra assinar: "Francisco Victor Rodrigues, o Manco." Casou com a Felicidade. Ouvi falar de um marido no estrangeiro que construiu um mausoléu maravilhoso pra mulher dele. Chico Manco homenageou a sua, viva: "Farmácia Felicidade." Devia gostar muito da D. Dadinha. Demaaais... O nome verdadeiro dela, Felicidade. Deu sorte?

Luise para na esquina... Bernardo morou aqui, no número 1182, quando voltou pela segunda vez, Delegado de polícia-Juiz Municipal. Pela cabeça da 
menina, palavras do Sr. Cornélio... "Bernardo não tinha preconceito, era um homem simples...” Sem preconceito, devia ser mesmo... Simples... Será? Já andei pensando nisso... Acho que às vezes uma coisa pode parecer simples e não ser. $O$ escritor era inteligente. Não à-toa conseguiu prova de amizade de homens muito duros... Fizeram questão de dar presentão pra ele. Cisne. Devia ser lindo. Bernardo gostou demais do mimo. Quem não queria ganhar um lindo cavalo branco pra ser só seu? Todo arreado Sela... Coxinilho... Baixeiro... Rebenque, castão de marfim... Tudo! Até caçambas. Diz que foi grande companheiro do poeta, na volta pra terra natal dele. Bernardo fez até um poema para o corcel: 'Adeus a meu cavalo branco chamado Cisne'. Se eu ganhasse um cavalo assim, acho que poderia querer criar versos pra ele também. O Sr. Cornélio diz que quando Bernardo fazia isso... "Talvez buscasse conhecer melhor a alma humana". Será isso possível?

84

O casarão tem histórias. Contam que depois que Bernardo foi embora, a dona voltou a morar nele. Senhora idosa. Devota do Senhor dos Passos. Tinha um oratório. Vela sempre ardendo aos pés da imagem. Sem herdeiros, fez testamento, deixando a moradia para o santo da devoção. Morreu. O chefe político quis anular o documento na justiça e ficar com o casarão Mandou buscar rábula famoso: 'Pássaro-Preto' veio de Paracatu para cuidar do caso. O advogado entrou na casa ainda de botas e esporas. Começou a redigir a petição. Parou. Levou a mão ao peito. Disse que sentia muita dor. Bebeu remédio que trazia. Caiu morto. O chefe político não desistiu, deu seu jeito e ficou com a casa. Alugou para um alferes da polícia, que veio para a cidade, com a famíla. Teve apoplexia. Ficou paralítico. Morreu abandonado pela mulher e as duas filhas. Francisco Faustino foi morar na casa. Certa tarde, na janela, olhando para a rua, distraído, um escravo, que o odiava, veio por trás e cravou nas costas dele um espeto de ferro. Um fazendeiro precisava colocar os filhos na escola e veio morar com a família. Morreu de gangrena com um bicho de pé inflamado. Um vendedor, de fora, estabeleceu 
armarinho sortido na casa. A loja faliu. Um abastado comerciante local comprou o lugar na intenção de nele residir, mandou reformar e benzer. De repente, desistiu, passou adiante, por preço menor e foi morar fora. Diz que o novo comprador acabou louco varrido. O chefão, que primeiro ficou com a casa do santo, não ganhou a eleição, perdeu o prestígio e acabou na miséria. O povo conta que quando o andor do Senhor dos Passos passava na frente da casa pesava tanto que precisava de reforço para ser sustentado e a imagem não cair. Fala de outros fatos estranhos acontecidos nela, como a bola de fogo verde, pairando sobre a cumeeira, nas noites escuras. Diz que a casa passou para as mãos do farmacêutico Cristiano Vitor Rodrigues bem na hora que os fenômenos pararam de acontecer e o azar virou sorte. $\mathrm{O}$ dono acabou premiado na loteria federal com cem contos de réis.

Essas histórias são contadas por aí... Quem sabe inventadas... Verdadeiras para quem acredita nelas... Mas as duas piores aconteceram não dentro da casa e sim do lado de fora. Nesta rua. Nesta quadra. Essas sim, histórias verdadeiramente verdadeiras. E nesta mesma esquina, aqui, a mais terrível delas. Bernardo já estava longe daqui quando tudo aquilo aconteceu. Ainda bem. $O$ escritor amava Catalão. Soube transmitir o sentimento dele pra a família, como um legado.

A menina pensa na carta do filho do escritor, publicada no Catalão Ilustrado, anos mais tarde da partida do escritor. Na missiva, muito eloquente, o filho de Bernardo fala que sente saudade, mesmo sem conhecer a cidade. Descreve a silhueta do casario. Diz que guarda com zelo uma fotografia da casa colonial onde o pai morou. Expressa gratidão para a gente generosa que acolheu $o$ juiz versejador e guardou como relíquias as primeiras legendas da sua intelectualidade. Achei tão bonito esse pedaço. Decorei. 
Depois da Guerra do Paraguai, Antônio Carlos de Andrade, capitão de infantaria do Exército, chegou à cidade, licenciado e se uniu ao partido do senador Paranhos. Em comum: aspiração política, tino comercial, ambição. Podia dar certo? Desentenderam-se. Separaram-se. Tornaram-se rivais. Cada um encabeçando um dos dois partidos políticos que acompanhavam as correntes do fim do Império e início da República. O capitão contando com o apoio do Império e se impondo na política municipal, até a Proclamação da República. O senador, descendente do Barão do Rio Branco, casado com uma moça de Paracatu, constituindo a família numerosa, radicado em Catalão. A luta política acirrada entre os dois culminou nos tiroteios que ficaram conhecidos como "primeiro e segundo fogos".

O primeiro fogo motivado por assunto corriqueiro. O capitão Andrade quis construir um moinho. Requereu à Intendência a autorização para represar a água do Pirapitinga pelo tempo das escavações. O Intendente, capitão João de Cerqueira Netto, indeferiu o pedido. O capitão Andrade ignorou o indeferimento do correligionário dos Paranhos. Represou. Escavou. Sem reação do Intendente. Ergueu o papa-vento para sugar água com torre. Os Paranhos sentiram-se diminuídos. Começaram a cozinhar desforra. Setembro. O índio Afonso adentrou a cidade com seu bando. Reuniram-se numa casa de mulheres. Ayres e Paranhos enxergaram a oportunidade para revanche. Os Paranhos espalharam boatos. “Afonso veio cobrar uma dívida do coronel”. "300 mil réis." "Por conta de um "serviço." Os Ayres exigiram enfrentamento das autoridades. Boateiros atiçavam: “Os correligionários não querem a dívida paga. Estão vendo?”. Argumentavam. "Querem que a polícia entre em confronto e saia desmoralizada com a vergonhosa derrota." De fato. O major Paulino não atendeu a exigência. Com seu efetivo de nove soldados mal armados, o delegado 'se fez de morto'. Os Ayres juntaram trinta capangas às pressas. Atropelaram a lei. Atacaram o bando de Afonso. Fuzilaria do início da tarde. Três dos Ayres tombaram sem vida. Afonso saiu da cidade. Sem baixas. Frustração dos Ayres. Tiros a esmo pelas ruas. Mestre Quincas, um veterano de guerra do Paraguai, ajudou o major Paulindo a freá-los. 
Aproveitando a alta moral, o major proibiu o porte de armas na cidade. Hum... Pra quê? Em Catalão, um homem sem um revólver na cintura ou uma carabina nas costas era um homem pelado. O prestígio dele despencou. Domingos Calaça saiu à rua com seu revólver. Ostensivo. Passou em frente à casa do major. Provocador. Levou uma descompostura. Não reagiu. Pediu desculpas. Convocado pelo capitão Andrade, o jagunço admoestado e recebendo ordem: "Passa lá de novo, armado." Calaça obedeceu. O major vociferou: "Teje preso". Ao invés de levar para a cadeia, manteve o homem em casa, perto do sobrado do senador Paranhos. Os companheiros de Calaça enviados pelo capitão para exigir a libertação do pistoleiro. Perderam tempo. Expectativa de luta. Autoridades municipais e funcionários públicos acorriam para a casa dos Paranhos. Ayres e partidários para a casa do Capitão Andrade, na mesma rua, um pouquinho adiante, do lado aposto, em frente à antiga casa de Bernardo Guimarães. A distância entre os dois sobrados podendo ser coberta por um grito.

1892. 16 de janeiro. Dez horas da manhã. Começou Primeiro Fogo em Catalão. Tiros disparados da casa do capitão para a do senador. Lá, além da família, o intendente, o juiz da Comarca, o delegado major Paulino e uma turma de jagunços. A resposta não tardou. Jagunços e soldados da polícia, irmanados, atirando das janelas da casa do senador em direção à do capitão, onde, além da família, estava José Maria Ayres, o líder, e Elyseu da Cunha seu lugar tenente. "Os tiros impediam homens se locomoverem, pelas ruas", conta Maria das Dores, muitos anos depois. "As mulheres transportavam armas nos braços protegidas por toalhas", modo de carregar os nenenzinhos na época. Tiroteio de uma hora. Acreditavam que a luta ia durar muito tempo. Preparavam-se para isso. Munição sobrava. Estoque grande, na loja do capitão, Andrade e na do senador Paranhos. De repente, a bandeira branca alteada. O tiroteio parou. O cônego Luiz Antonio, cunhado do senador, atravessava a rua com ela. Prestara-se a intermediar o cessarfogo. A irmã dele, D. Belizária Paranhos sofrera uma crise nervosa. "Essa crise 
nervosa é pretexto.", disseram os que achavam que os Paranhos estavam em desvantagem numérica. Negociação dura. Condição imposta. O senador Paranhos devia se retirar da cidade com a família. Rendição aceita. Fim do tiroteio. Escaramuças pipocaram. Resultaram na morte de um jagunço. Muito bem aceita. “Onde já se viu tanto tiro sem nenhuma morte!" Chacota pra cidade. "Não ficava bem." Paranhos se retiraram. Humilhados. Recolheram-se na Fazenda Ribeirão. Cercado pelos parentes, amigos e correligionários. O fazendeiro tinha prestígio político municipal dilatado: chefe do Partido Liberal do município, deputado provincial em Goiás por duas vezes, presidente da Assembleia Legislativa do Estado. Com a proclamação da República, angariou influência federal no Governo Republicano e foi eleito Senador pela Constituição de 1981, na primeira legislatura republicana. "O senador solicitou força federal."

Paranhos e o filho Ricardo foram a Araguari e se inteiraram da data em que unidade do governo republicano iria para Catalão garantir a ordem. Pai, filho e setenta partidários entraram na cidade no mesmo dia da chegada da tropa federal. Poupando-se de assistir a exibição de força, o Capitão Andrade e José Maria Ayres, na retirada estratégica para se refugiarem nas respectivas fazendas. Elyseu da Cunha fincou pé: "Faço questão de ficar!" O batalhão número vinte permaneceu na cidade por alguns meses. Paranhos em evidência. Sobrado entupido de gente. Clima tenso. Tempo de eleições municipais. Campanha eleitoral intensa. Rivalidade. Bajulação. Paranhos derrotados pelos Ayres. Arrogância. Incômodo. O Capitão Andrade tocaiado a caminho da sua fazenda. O atirador errou o tiro. Felipe Estrela, casado com uma neta do Senador Paranhos, tido como o autor do atentado. Abertura de inquérito. Nada apurado. Juras de vingança dos correligionários do Capitão. Os companheiros incitando a agir diretamente contra o senador. O filho dele enviou o jagunço Veridiano ou Atanagildo ou Negrão, temido em São Paulo e em Minas Gerais por seus feitos à bala e à faca, insistindo com o pai para contratá-lo. Negrão chegou à cidade. $\mathrm{O}$ Capitão tomou seus serviços. Afoito para se exibir, Negrão menosprezou a fama dos de Catalão: "Povo bom de briga." "Gente boa de tiro." Entrou num duelo. Saiu baleado. Com a derrota atravessada na garganta, foi curar a ferida na fazenda do capitão. Acoitado na olaria dos imigrantes espanhóis, trabalhadores do chefe. Surpreendido pela força policial, que chegou para prendê-lo, reagiu. No saldo do 
tiroteio, alguns soldados feridos, duas crianças espanholas mortas. Negrão perdeu o que sobrou da crista. Obrigado a fugir para Minas Gerais.

87

30 de novembro de 1897. O senador Paranhos levantou cedo no dia em que o matariam. Tinha sonhado que saíra de casa, sozinho. A rua estava deserta. Caminhara reto até a esquina, descera o beco entre a farmácia e a casa do capitão Andrade, que levava à Rua da Capoeira. Local preferido pelos escravos, estonteados ainda com a liberdade recém-conquistada, dançando batuque a noite inteira, sob as gameleiras crescidas entre velhas cercas de aroreiras. No sonho, o senador andava pelo arremedo de rua entre as touceiras de esporão-de-galo, espinhos-agulhas e palmas de mandacaru, procurava um tropeiro e um peão de boiadeiro. Uma chuvinha mansa começou a cair. O senador fez o caminho de volta. Subiu o beco até a rua principal. Desembocou entre a Farmácia Felicidade e a casa do Capitão Andrade. Não chovia mais. No meio da rua, a grande umburama à sombra da qual, duas ou três gerações comentaram antes os acontecimentos corriqueiros da então pacata cidade do interior goiano. Passando debaixo da árvore, sentiu uma coisa morna caindo na cabeça. Passou a mão. Lambuzou-se de titica. Olhou para o alto. Não reconheceu a ave. Era grande. Voava raso. Acordou e se deu conta de que estivera sonhando. Dormira mal. Sentiu gosto de 'cabo de guarda chuva' na boca. Antes do café, contou o sonho para a mulher. D. Belizária viu augúrio ruim. Tinha reputação na interpretação dos sonhos dos outros. Era o dia do julgamento da mulher de sobrenome Pinheiro, acusada de homicídio. O senador, membro do júri. Os companheiros esperavam para acompanhá-lo à audiência. Ficaram com ele até cerca de duas horas da tarde, quando foi estraçalhado à bala. Lembravam-se dele sonolento, mas de bom humor. Com todos comentou que era um dia bonito. Ninguém estava certo se ele se referia ao estado do tempo. Muitos coincidiam na lembrança de que era mais uma manhã radiante de novembro. A maioria, contudo, falava de um tempo carregado, céu baixo, a ponto de desaguar a qualquer hora. O Senador se vestiu 
com apuro. Não fosse pela audiência, vestiria uma roupa mais informal, calçaria as botas de montaria e iria para a fazenda. Os faustos da Justiça provocavam nele fascinação irresistível. Ao sair para o julgamento da ré, "Defendida pelo próprio Senador Paranhos", como disseram alguns, foi alertado por sua mulher e aconselhado pelos companheiros a não passar pela porta do Capitão. Para chegar ao sobrado da cadeia, com a sala de audiências no segundo andar, era só seguir em linha reta, à esquerda. Deu volta ao invés. Subiu o jardim, dobrou na esquina do Dr. Lamartine, seguiu pela Rua de Cima e desceu na quadra do Sr. Romualdo Borges. Na sala de audiência, surgiu Olinto Victor Rodrigues, esbaforido, avisando... "Elyseu da Cunha entrou na casa do Capitão". O conhecido contador de lorotas, não foi levado a sério. "O Negrão tá com ele” insistiu. Ninguém se impressionou com seus prenúncios de acontecimentos sombrios. "Ele e o capanga, com rifles a tiracolo". Na época era comum entrar armado na cidade. Principalmente voltando da fazenda.

O Júri terminou por volta das duas horas da tarde. A ré absolvida, como esperado. Saiu na companhia dos jurados e dos amigos. Cerca de quinze pessoas todos eufóricos. caminharam pela Rua do Comércio para um café na casa do senador, na praça do coreto. O grupo ultrapassou a grande umburama sombreando parte da via pública. Atravessou a rua entre a Farmácia Felicidade e a casa do Capitão Andrade. Portas e janelas fechadas. O mulato Franklin de Araujo sentado no degrau do comércio no andar de baixo. Como que de vigia. O político cumprimentou. Na rua, falava com todos indistintamente. "Boa tarde, Senador Paranhos", respondeu Franklin bem alto. As pessoas estranharam. Parecia uma senha. E era. Um aviso para os que estavam entrincheirados atrás do balcão comercial do Capitão. O senador deu cerca dez passos. A descarga de tiros veio da casa do Capitão. O senador e o neto, atingidos. O velho caiu de joelhos, tentou se levantar e recebeu a descarga mortal. O jovem saiu capengando e foi socorrido pela tia, no sobrado pegado à Farmácia Felicidade, cinquenta metros adiante. Debandada geral do grupo. Alguns, feridos. Largando chapéus, bengalas, guardachuvas e outros objetos pelo caminho. Dodô e Benzinha, duas das cinco filhas do senador, enfrentando o tiroteio e arrastando o corpo do pai da poça de sangue para dentro de casa. Voltando e recolhendo a terra empapada nas próprias saias. Não dariam oportunidade para profanarem o pai. Não sofrerem arranhão. Sorte? Poupadas? Depois de dois dias insepulto, as duas moças conduziram o corpo ao 
cemitério por ruas não alcançadas pelo tiroteio ininterrupto. Parentes, amigos, jagunçada a serviço engrossavam as duas hostes inimigas. Os partidários dos Paranhos municiando-se na loja do próprio Coronel. Os do Capitão dispondo da farta provisão de cartuchos na casa comercial. Os Ayres moravam em frente ao sobrado e participavam. Escutando a ordem "Fogo nos Ayres!", os jagunços entendiam "fogo nos ares", viravam os rifles para o alto, acertando o estuque sob o qual estavam entrincheirados.

Tudo isso aconteceu quase em frente da casa em que Bernardo Guimarães morou. Poderia o inventor de tramas e histórias dotado de poder criativo, observação arguta e potência imaginativa de alguma forma antecipar o que viria ocorrer em frente à casa que morou? Conhecendo bem o cenário, talvez tenha ficado horrorizado ao tomar conhecimento da perda do amigo e imaginado o sangue dele empapando a rua.

A morte do senador acendeu o estopim do segundo fogo. A casa do Capitão cercada por cerca de trinta homens. Tiroteio dia e noite. A luta desarticulava a cidade. Deixava a população em pânico. Ninguém da zona rural entrava na cidade. Moradores das proximidades dos grupos em luta se retirando. Qualquer um que se arriscasse a transitar pelas ruas poderia ser vítima de um disparo. Um rapazinho que entreabriu a janela do sobrado e espiou o casarão do Capitão, num breve momento de interrupção do fogo, levou um tiro na testa. Enviados partindo em busca de ajuda estadual e federal. As noticias se espalhando. Uma das moças que conduzira o corpo do pai conseguiu se esgueirar pela calçada e chegar à casa do inimigo, seguida por um capanga. Despejou querosene e tocou fogo nas portas e janelas. O incêndio custou a ser dominado pelos entrincheirados. Depois de três dias, o experiente Capitão da Guerra do Paraguai reconheceu sua desvantagem. Ordenou que avivassem o fogo. Fez escapar a família pelo quintal. Alcançou a Rua da Capoeira. Vadeou o Pirapitinga e seguiu para lugar ignorado. Ao amanhecer do quarto dia, silêncio total, na casa do Capitão. Insultos. Tiros. Provocações. Resposta nenhuma. Aproximação cautelosa dos de fora. Invasão da casa. Vazia. Um buraco no porão. Por onde os de dentro rastejaram. Escaparam. Para onde? Ninguém sabia. Quincas Estrela, da Fazenda Pires, casado com a neta do Senador, campeou dois dias. Encontrou rastros de tropa ferrada fora da estrada. Era uma pista. "Na direção da fazenda dos Gonçalves", levou a notícia aos 
Paranhos. Ofereceu para perseguir o grupo "Nas terras dos correligionários". Convocou seis ou sete homens armados. Acabou prendendo o Capitão, o filho dele Carlito e mais três homens. O esperto Elizeu da Cunha escapou. Na porta da cadeia, a aglomeração dos curiosos e da parentela, dos dois lados. Ricardo Paranhos deu uma chicotada na cara do Capitão. Estrela desaprovou a atitude, interferiu e impediu novos incidentes colocando os presos na cadeia sob a responsabilidade do delegado.

"D. Josefina do Porto morava perto da cadeia. Portos e Andrades, entrelaçados. Um filho dela casado com uma filha do Capitão. D. Josefina ofereceu ao soldado João Henrique, "quinhentos mil réis para facilitar a fuga dos presos." Ele aceitou. Deu com a língua nos dentes, numa venda. Chamado por Estrela, o homem de mais força com o afastamento dos dois líderes, contou tudo. Estrela dobrou a proposta, orientando o soldado a levar o plano adiante, deixando-o informado de tudo. Fuga preparada para a meia-noite. Sem lua, valendo-se da escuridão, a cidade ainda sem luz elétrica. Do lado de fora, Estrela e homens armados. Observando escondidos. Aflitos. Ansiosos. Apreensivos. Primeiro, desceu Carlito, o filho do Capitão. Depois, o jagunço João Paula. Por último o Capitão veio descendo, esperaram ele se desligar do parapeito da janela, deram a descarga de tiros. O Capitão rolou pelo chão. Morto na hora. Ambas as famílias sabiam e esperavam aterrorizadas o desenrolar dos acontecimentos.

Os parentes do Capitão se mudaram para uma cidade vizinha. D. Josefina do Porto providenciou o enterro dele no cemitério local. Catalão, afamada. "Cidade de tiroteios." "Terra de valentões." E a pergunta que não queria calar: "Onde andaria Elyseu da Cunha?"

Caçado, Elyseu andou se escondendo pelas matas que bordejavam o Paranaíba. Caso precisasse poderia facilmente atravessar o rio e fugir para Minas Gerais. Depois, ele se recolheu na própria chácara, em Anhanguera. Tropas no encalço. O cabo Anastácio, chefe do destacamento, dando ordens do aos soldados: 
"invadir, arrancar, trazer "vivo ou morto". Recepção violenta e intensa. Os soldados esbaforidos em debandada. Alguns enganchando no arame farpado. "Elyseu riu muito, vendo os restos dos fundilhos das calças da soldadesca, ao vento.", contou alguém depois. Paranhos não desistiriam. A tropa voltaria reforçada. Elyseu não quis esperar para ver.

Em Catalão, o Major Felipe Estrela, Ricardo Paranhos e Alfredo Paranhos, filho e neto do senador, mandando-desmandando. A oposição liderada pelos Ayres enfraquecida. Tudo indicava que o mandanismo dos Paranhos iria durar. Viravolta na política goiana. Revolução na Cidade de Goiás. Elizeu da Cunha e o filho Isaac da Cunha juntos na legião comandada por Eugênio Jardim, ex-militar e político lutando pela deposição do governante do Estado com a tomada da capital, Goiás. Revolução vitoriosa. Eugênio Jardim com as rédeas do poder estadual. Elyseu da Cunha apoiado pelo homem forte do momento. Alfredo Paranhos enfraquecido. Sem apoio do governo e de Christiano Victor Rodrigues. Elizeu volta a Catalão. Politicamente bem escorado. Assume a cadeira de intendente. Apresenta-se ao delegado Marcylio Ayres, filho do Coronel José Maria Ayres, velho aliado político dos Cunha. Pleiteia um segundo julgamento. Quer ser absolvido da morte do senador. O julgamento é marcado para o mês subsequente. Duas testemunhas que depuseram no processo anterior tinham morrido. Outras duas não foram encontradas. Das seis intimadas, nenhuma compareceu. O júri concluiu que o réu não atirara em ninguém.

Ouvindo contar que, naquele tempo, cresceram boatos de que Elyseu iria invadir a casa do coronel Alfredo Paranhos, Luise lembra a vez que entrou em casa e viu o padrasto, rindo largo e dizendo... "Cadê perna? Ha-ha-ha...". Nunca pensei que o Sr. Esteves fosse capaz de rir daquele jeito e mal pude acreditar... "Alfredo que andava sempre bem armado e acompanhado de perto por cerca de seis guarda-costas." “Quem será esse homem capaz de fazer meu padrasto gargalhar?", pensei quando o Sr. Esteves falou no Elyseu. "Naquela 
noite, Alfredo recomendou aos jagunços: 'Olho vivo e ouvido atento. Jagunço de Elizeu além de matar carrega as orelhas' e Davi Có-có, do seu canto, não perdeu a oportunidade de se mostrar: 'Deixa comigo coroné, eu sozinho cabo com essa praga". Madrugada. Tropel na rua. Todos em alerta. Os jagunços presos nas cadeiras, carabinas no colo. O cachorro latiu no quintal. O Coronel foi espiar. Viu o bode acuado pelo cão subir nos latões de leite e as vasilhas rolaram pelo terreiro, numa barulhada infernal. O Coronel voltou à sala, os jagunços tinham fugido, só Davi Co-có tava lá, carabina do lado. Alfredo explodiu. 'E se tivéssemos que enfrentar a cambada do Elizeu? Somente eu e o Davi... O único que não teve medo e ficou... Merece até um aumento... Os outros... Corja de patifes... Fugiram com a primeira bulha e palha... Covardes...' Virou para David e perguntou: 'E você Co-có, não correu por quê?' David, ainda trêmulo, mal pode gaguejar: 'De que jeito Coroné? Cadê perna?' Então foi por isso... Naquele dia, cheguei e vi o meu padrasto, que não era de rir, rindo muito, no fim dessa história. Só agora, depois de escutar inteirinha, posso entender a graça, que ele achava nela.

"Nesse clima, os herdeiros do Coronel Paranhos deixaram a cidade. Ricardo mudou-se em Araguari, onde possuía fornecedora de dormentes de estrada de ferro. Alfredo foi morar em Bagagem, hoje, Estrela do Sul".

90

Nessa época, surgiram os apelidos "papo roxo" para o partido Republicano e "papo amarelo" para o Democrata. Nomes que remetiam às chapas das carabinas nas cores dos partidos que se digladiavam em lutas ferrenhas. Na facção política do Capitão Andrade: Aires, Victor Rodrigues, Gomes Pires, Paivas. Ouvindo esses nomes, Luise... Hã!? O Auro é um papinho-amarelo... Não acredito! O apoio político renovado na pessoa de José Maria Aires da Silva, Randolfo Campos como mentor intelectual. No partido liderado até então pelos Paranhos, João Netto Carneiro assume o poder. Em véspera de eleição, era comum os mais entusiasmados usarem fitas e laços na lapela, na cor do partido. Nenhum 
partidário do papo roxo usava em seu traje cor amarela, nem plantava flor amarela em seu jardim. Do mesmo fazia o do papo-amarelo.

A luta política entre os dois partidos marcou época em Catalão por mais de quarenta anos. Aires e Victor Rodrigues famílias prestigiosas, Elizeu da Cunha o mandante de fato. Seu correligionário, Manoel Gomes de Paiva Rezende, o Nequinha Gomes, o intendente municipal.

Nequinha tinha um filho, rapagão de boa aparência, fisicamente forte, olhos e cabelos claros, Salomão. Personalidade controvertida. Qualificado por adjetivos contraditórios: justo bondoso, valente, espirituoso, bonito, perverso, valentão, violento, grosseiro, atrevido.

Quem era Salomão de Paiva? Cavalheiro perfeito que se apresentava vestido com apuro, comunicava-se com a maior polidez, sabia ser gentil e maneiroso com os amigos, agradável com as moças, brincalhão com as crianças. Brutamontes, provocador e turbulento. Cercado de jagunços, atemorizava com bravatas, aproveitando a posição do pai, para fazer arruaças e praticar violência.

Anjo ou demônio, Salomão acabou substituindo o pai no executivo municipal. Eleito pela força ou não. $\mathrm{O}$ intendente gostava de se divertir saindo às vezes à noite para beber. Perambulava pelas ruas mal iluminadas com um bando de arruaceiros, revólver em punho, apostando atirar nas poucas lâmpadas elétricas então existentes. No dia seguinte, ele intendente mandava trocar as quebradas por novas, que em qualquer noite iria de novo quebrar.

Em tempo de eleições, os asseclas fiscalizavam as seções eleitorais para garantir a vantagem para o partido da situação. Época do voto "a descoberto", que sucedeu o "voto a bico de pena", eleitor votava publicamente. Não precisava saber ler. Escoltado por elementos forçando o voto. Na dúvida quanto ao resultado, urna recolhida, inversão mágica de votos, morte de adversários, comparecimento ao 
enterro, condolências enviadas à família. Protestos da oposição, rejeitados com a aprovação do Tribunal do Dr. Antônio Ramos Caiado.

Escudado por parentes poderosos, chefes de partidos políticos em Monte Carmelo e Estrela do sul, Salomão aumentou a fama da violenta Catalão. Um dia não teve escrúpulos em entrar a cavalo na residência do delegado Furtado de Mendonça, vindo do Rio de Janeiro. Era comum Salomão entrar num bar ou outro da cidade, convidar os que dele se acercassem a beber, sair sem pagar a despesa, com todos embriagados dando tiro para o alto. Algazarra. Gritaria. Os moradores aterrorizados obrigados a se trancarem dentro de casa. De uma feita, implicou com o novo delegado que chegou a Catalão. Levou o homem a beber com ele a noite inteira, tendo que tomar parte na baderna. No dia seguinte, Salomão livre dele. O Delegado ficou envergonhado e pediu demissão. O intendente Salomão rendeu fortes histórias.

$\mathrm{Na}$ gestão de Salomão, Vital Brasil tomou conhecimento de cobras abundando na região e visitou município para falar aos camponeses sobre o soro antiofídico, sua descoberta para neutralizar o veneno. O recinto improvisado para a palestra estava cheio, um benzedor de origem espanhola interrompeu o conferencista e perguntou em portunhol: "Es verdad que las cobras mamam?" Naquele tempo, a crença de alguns de que cobras podiam entrar no quartos das mulheres lactantes, no escuro, colocar a ponta do rabo na boca do nenê e mamar no peito da mulher. Vital Brasil explicou pacientemente que as cobras não têm músculo de sucção como os mamíferos. O espanhol protestou em altos brados: “Entendes de veneno e não de cobras, 'eres’ um ignorante”. O cientista contornou delicadamente a situação. $\mathrm{O}$ incidente chegou aos ouvidos de Salomão. Contrariado com o vexame, chamou o guarda-costas Lucio Madeira, e mandou buscar o espanhol para dizer a ele: "Envergonhando a nossa cidade, heim charlatão? Seu benzedor sujo! Tem 24 horas pra se desculpar com o Dr. Vital ou 
sumir no mundo!" Ninguém soube mais do espanhol. O povo contando o caso dizia: "Justiça de Salomão".

De outra feita, Salomão enrabichado pela Bernardina a ponto de colocá-la numa casa das proximidades da Praça Duque de Caxias por sua conta, quando o lugar não passava de um cemitério em ruínas. José Carretel, um fazendeiro de Olhos D’água, se desentendeu com mulher, bateu na mulher e ainda disse a ela: “ Tá pensando que mulher de intendente não apanha? Apanha sim. E pode dizer ao Salomão que eu não tenho medo dele e nem dos seus jagunços”. Salomão furioso. Mandou Zacarias e Antonio Nunes a Olhos D’água liquidar o fazendeiro. Os jagunços foram descobertos mortos e enterrados no fundo do quintal. Carabinas jogadas num açude. Na época das águas, os moradores da fazenda em pânico. As chuvas fortes arrastaram as terras das sepulturas rasas e deixaram os pés dos defuntos descobertos. Recobertos, as chuvas voltavam, descobertos. A fazenda considerada mal-assombrada.

Zé Carretel continuava ameaçado de morte. Enviou Lucio Madeira e Zé Taipeiro matar Salomão. Interceptados na passagem do Córrego Água Suja, foram mortos e jogados na ribanceira.

Enquanto isso, a Bernardina mantinha seu romance secreto com o maquinista português Manuel Parada, indo semanalmente se encontrar com ele em Ouvidor. Ponto final da linha de ferro. Local de pernoite. Quando o trem da Goiás vindo de Goiandira se aproximava de Catalão, o maquinista puxava a corda do apito da Maria-fumaça com repique diferente e lá ia Bernardina correndo para a estação pegar o trem.

Zé Carretel acabou morto numa roça de milho, numa emboscada aramada pelos jagunços do Salomão. E o português continuou apitando a Maria-Fumaça para chamar a Bernardina. Um dia resolveu tomá-la só para si. Embarcou a 
mulher no trem da Goiás e foi morar com ela em Araguari, longe da sombra do Coronel.

94

$\mathrm{Na}$ época de Salomão, Isaac da Cunha sucedeu o pai Elizeu da Cunha na liderança política. Contam que Elizeu acabou louco vagando pelas ruas e falando sozinho: alardeava que tomara parte na morte do velho Paranhos e o seu tiro certeiro derrubara o senador. Morreu de velhice. Diz que o filho era mais culto, mais hábil, mais moderado e não teve dificuldade em alcançar prestígio como chefe político. Mesmo assim, foi no tempo dele que aconteceu o caso dos ferroviários.

A Estrada de Ferro Goiás avançava em direção a Ouvidor. O acampamento dos ferroviários nas proximidades da Boca da Onça, o bairro onde morava Sana Neiva, a preferida do comandante do destacamento policial. Alto, desengonçado, conhecido como 'Suã de Vaca' por ser considerado muito feio.

Dois ferroviários passando pela frente da casa, janela larga e aberta para a rua, viram a mulher em trajes menores, penteando os cabelos e pintando o rosto diante de um espelho se expondo aos transeuntes. Diante da provocação um dos ferroviários se aventurou.

- Vai ser boa assim no inferno! E aí, boneca, pode ser ou tá difícil?

— Sai fora, porco! Eu sou lá mulher de dar confiança pra moloqueiro?

O moço avermelhou de raiva. Deu ponta pé na porta, entrou e agarrou a mulher. Ela reagiu, lutou e escapou. Perseguida. Alvejada. Morta no meio da rua.

'Suã-de-Vaca' era amigo do Isaac da Cunha. O manda-chuva político ordenou a captura do criminoso pela polícia. Recusa dos ferroviários em entregar o companheiro. Troca de tiros. Um soldado morto. O Coronel e o Comandante esperaram os ânimos esfriarem calculando a desforra. 
O trem de serviço saía de manhã com as gôndolas cheias de trabalhadores para a ponta dos trilhos e voltava de tarde trazendo os homens de volta para o acampamento. Um dia, obstáculo nos trilhos. A pilha de dormentes obrigou a locomotiva a parar. A polícia entrincheirada à beira da linha. Reforçada por um grupo de jagunços. As armas descarregadas nos ferroviários. Doze mortos na hora. Quatro menores. Polícia e jagunços se dispersando, acobertados. Feridos socorridos pela população e levados às pressas para um hospital improvisado no Colégio N. Sra. Mãe de Deus. No meu Colégio... Que tristeza! Só de pensar que o mulherengo do meu pai podia estar metido no meio...

O intendente Salomão cada vez mais cercado de desafetos, contratou Caldeira como chefe dos seus guarda-costas. Na voz geral, Caldeira deu baixa na polícia para ser "mais um dos seus jagunços." As badernas do intendente incomodavam os papos-roxos e mesmo alguns dos próprios papos-amarelos.

O Coronel Luiz Sampaio sendo substituindo pelos filhos na liderança da família. Diógenes Sampaio de olho na chefia política do município; o irmão, João Sampaio, ambicionando o título de mais valente que, para ele, valia mais que qualquer cargo.

7 de setembro de 1924. Desfile comemorativo dos estudantes. Salomão de Paiva no palanque das autoridades, presidindo a Parada da Independência. João Sampaio misturado ao povo assistindo. Repassando plano traçado: Caldeira, morto primeiro e Salomão, depois. Naquele mesmo dia.

Na parte alta da cidade, dois homens chegaram e atiraram no guarda-costas, sem dar tempo ao jagunço de perceber o que acontecia. O intendente Salomão de Paiva morto numa venda em frente a casa do Sr Lourenço Cortopassi, pouco mais tarde. A cidade verteu lágrimas. A cidade soltou riso. 
O suplente Mario de Cerqueira Netto, Nhozico, assumiu a intendência. Irriquieto, alegre, atuante, na sua gestão apareceu a banda de música do Maestro Piraí, depois do Sr. Eduardinho. Augusto Carneiro, mentor político da família, sucedeu o Nhozico na Intendência, tratando mais do embelezamento da cidade: abriu ruas, removeu terras, construiu a primeira praça pública da cidade: o bonito jardim e o belo coreto foi inaugurado com o nome de Eugênio Jardim, mais tarde substiruído por Praça Getúlio Vargas.

Os apelidos papo roxo e papo amarelo duraram até a revolução de 30 . Diógenes Sampaio ocupava espaço político, teve que esperar Antonio de Paiva Sampaio e Jocelin Gomes Pires passarem pela Intendência, antes de ser nomeado prefeito pelo interventor Pedro Lucovico.

De lá para cá uma série de prefeitos nomeados até a eleição de João Netto, que há quem acredite, foi milagre de Antero.

96

Fim da ditadura Vargas. Eleições gerais. 1946. O jovem líder João Netto de Campos disputa com a situação coronelista o cargo de prefeito de Catalão.

Voto feminino implantado. As mulheres rezando aos pés da cruz que marcava o lugar onde Antero morrera. Pedidos e promessas para Joãozinho ganhar as eleições e acabar com o clima violento de vez. Eleito com larga vantagem. Dominou a política por muitos anos.

Depois dele outros candidatos não puseram em questão a fé na força espiritual contra a força bruta. Os que ganharam, pagaram promessas feitas a Antero, por seus eleitores.

Nettos e Sampaios, rivalidade política enorme. 'Quartel dos Netos' na Rua Estreita. 'Quartel dos Sampaios', nos quintais.' Última semana antes da eleição, 
euforia crescente intensificando a competição. No vale tudo do jogo: cédulas trocadas, quilos de sal amargo jogados em cisterna, partidários desandando.

O tempo veio. Luise acompanhou a mãe no dia da eleição pela primeira vez. Não compreende porque é apoderada por um sentimento estranho quando vê as cozinheiras gordas tirando a comida dos panelões enormes e servindo aos eleitores de pratos estendidos... Não sei por que... Mas fico meio envergonhada de assistir o povo encolhido e calado recebendo esse almoço... Arroz, feijão, mandioca, almôndega quase do tamanho de uma laranja...

"Vamos, gente! Joana apressa as filhas. Prometera levar a Pitida para visitar a madrinha de crisma dela. Luise junto. Dona Cota mora lá pelos lados do Marcatempo. Subindo a Rua Cristalina, a mãe mostra a casa do cantor-perneta.

— Aquela é mulher do Sr. Zé Paixão.

Luise surpresa.

- Anda sempre sozinho, não podia imaginar que era casado.

- Tem três ou quatro filhas.

De repente, música bela. "Vem do largo das mangueiras." Estão quase lá. Som maravilhoso. Canto de sereia. Atrai os transeuntes. Plantado da noite para o dia, debaixo do arvoredo, o acampamento de ciganos chama a atenção. Os caminhantes. Retardam o passo, olhando. Como as meninas fazem agora. Devagar, quase parando. Admiram o jeito de vida daquela gente. Diferente! O colorido alegre enche as vistas. Ao redor das choupanas, quinquilharias espalhadas... vasilhas de cobre... tachos... Mulheres de roupas largas, algumas, com grandes lenços na cabeça... Crianças desgrenhadas... Homens de calças 
justas, mangas bufantes... Andando de um lado para o outro... Um deles, toca o violino. O som encantador enche os ouvidos. Joana puxa as filhas. "É preciso cuidado com esses bandos." Adverte. No meio da traquitana, animais... "Por onde passam roubam porcos, galinhas... Negociar com eles é um perigo. Enganam todo mundo. Batizam criança novinha muitas vezes. Nos lugares em que acampam, convidam alguém rico pra ser o padrinho e levar o dinheiro dele. Diz que roubam crianças... Desmontam as barracas de madrugada e botam o pé no mundo. Nunca mais são mais encontrados". Pitida, olhos arregalados, escutando a mãe. Luise admirando os vestidos e pensando na Leontina... "Se ela fosse levada embora na garupa de um cavalo desses... Teria mais graça na vida. Viajar o tempo todo... Lugares, diferentes... Conhecer coisas novas... Pessoas... Quem sabe alguém especial... Acostumada a mexer com tecidos finos, nem sentiria a mudança, fazendo roupa pra ciganada... Seria bom ver a Leontina abraçada por mangas bufantes... Pra desespero das freguesas... Levada embora, no pescoço de um cavalo... Montado por um cigano, roubando a 'costureira de mão cheia' e desaparecendo às gargalhadas.

98

Domingo. Luise compra seu ingresso na bilheteria do cinema e encaminhase para o fim da fila. Vai esperar a hora de abrir e entrar, como sempre faz. "Luise!" Surpresa. A lourinha que conhece apenas de vista faz sinal para ela se aproximar. Sorriso no rosto. Jeito amigável. Luise vai. Regulam em idade. Começam a conversar. A outra faz perguntas. Acabam falando de tudo: filmes, escola, família, menos namorado. A porta do cinema abre. A lourinha diz que está sozinha. Chama Luise para fazer companhia. A Menina não tem motivo para recusar. Fazer amizade é sempre uma coisa boa. Aceita o convite. Entram juntas. Escolhem os lugares. Sentam. Luise estranha a outra reservando a cadeira do corredor e sentando na segunda da fileira. Falou que tá sozinha. Ocupa a terceira e nada pergunta. Dado o sinal, as luzes se apagam e Luise recebe tremendo choque. O Auro tá aqui! E não por causa por causa de mim. Não é 
possível! Veio sentar na cadeira guardada por essa outra? Não pode ser... Não pode ser... Não pode! Auro senta e Luise levanta, ao mesmo tempo. Sincronia perfeita. Parecia ensaiada. A menina desliza rápida e aturdida para o outro lado. Vai embora. Sem desperdiçar palavra. Sem dirigir um olhar sequer. Volta para casa. Tonta. Desorientada. Nem conhecia a barata descascada! Como poderia desconfiar dela? Planejou tudo. Por que foi capaz de tramar ferir dessa maneira? Frieza! É perigosa como a espirradeira...

Luise lembra que, certo dia, na rua, caminhando com a mãe, parou, encantada, olhando os cachos de flor, carregados...branca... rosa....

— Não é uma lindeza?

- Bonita sim, Luise, mas a espirradeira não é flor que se cheire.

- Por quê?

- Não à-toa tem esse nome... Costuma guardar um bichinho dentro dela, que pode entrar no nariz e fazer a pessoa espirrar até a morte.

Tem gente assim também... Agora sei... Aquela talzinha é uma dessas... Carrega veneno dentro dela.

A vez que Luise passou pelo desgosto de ver o Auro e a "barata descascada", juntos, foi única. Nunca pôde ter certeza de ter sido vista antes, por ele, até o ímpeto com que se levantou. Na grande tristeza, pequeno consolo... Talvez, naquele momento, ele tenha percebido a armação da lambisgóia e desistido de namorar com ela, ali mesmo, naquela mesma hora. Ainda bem que o namoro não rendeu. Bem feito! Pela primeira vez, Luise sente as agulhadas do ciúme. Tira o apetite. Leva o sono. Acaba com a graça de tudo. A gente não escolhe sofrer... Por que fui conhecer o Menino? Por que o pensamento traz sempre ele de volta? Queria tanto poder arrancar fora de mim esse sentimento que tenho pelo Auro... De uma vez por todas! 
Joana vai visitar uma amiga e chama Luise, para ir junto. A menina vai pra tentar se distrair um pouco. Logo que chegam, a amiga leva as duas para verem o quintal da vizinha. Passam pelo portão da casa, fechada e silenciosa, seguem direto para os fundos. Um pequeno cemitério?! Luise boquiaberta vendo sobre os canteiros... mudinhas de alface, raquíticas cenourinhas, miúdos pés de salsa e cebolinha... Arrancados fora antes do tempo. Diante dos cadáveres arrumados com todo cuidado, cabeças para o mesmo lado e pés para o outro, meticulosamente alinhados, cada qual do lado da própria covinha, a menina estupefata... Nenhum escapou com vida! Todos deitados! Nenhum de pé!

Do lado, Joana segura o queixo e cochicha com a vizinha. "A Dedeia devia estar enlouquecida..." A outra replica com certa dureza na voz. "Mas precisava lançar a fúria ciumenta contra o que menos podia se defender? Ao invés de sacrificar a horta, que o marido tratava como se cuida de filho, podia bem ter usado o tratamento que as mulheres daqui têm para esses casos.... Eu mesma teria ajudado ela atochar de pimenta aquele lugar da outra e calcar bem”. Vendo a mãe, calada, pensando talvez em si mesma, a filha desconfia... Acho que já sabia antes de vir aqui... Alguém deve ter contado... Ela quis ver. Da conversa em voz baixa, a menina entende que a mulher, traída, matou a horta inteira, para se vingar do marido! $O$ tal amor só faz doer... No aparece-desaparece, às vezes, deixa a pessoa louca e capaz das maiores esquisitices...

Entendido isso, a própria dor da menina faz ela deixar de enxergar o quadro fúnebre, apenas pelo lado dos vegetais sacrificados e assumir também o ponto de vista da mulher sofrida. Luise imagina Dedeia desesperada de ciúme derramando quantidade enorme de lágrimas, matando o que marido gostava... Arrumando os corpinhos, com todo capricho, pra ele ver e ficar ainda mais ferido... Como vou poder descrever isso pra vovó? Que palavras eu vou poder usar? Tô procurando alguma... Não consigo lembrar de nenhuma que fale a verdade do que estou vendo aqui... 
Dias piores vieram. Luise não se lembra de ter visto a avó doente. Agora adoeceu e parece coisa grave. Acamada por muitos dias. Na escola também as coisas não andam boas. A menina está perdendo o fio da meada em matemática com a freira substituta da Irmã Carmélia. Não entendo porque a minha professora teve que voltar para a Espanha tão de repente... Ah... gosto tanto da irmã Carmélia! Sentia-se bem preparada, segura, com os ensinamentos dela, nem se abalou quando teve de enfrentar a banca de avaliação no exame oral das provas finais, do ano anterior. Chamada para sortear o ponto, enfiou a mão na sacolinha roxa tranquilamente e começou a encaminhar corretamente o exercício, quando ouviu o elogio do professor convidado... "Os seus alunos estão realmente muito bem preparados". Luise viu a professora corar e agradecer com a voz meio rouca. Terminou os cálculos e ouviu outro elogio endereçado à professorinha dela. "Seu trabalho é excelente, Irmã... Parabéns! A jovem freira baixou a cabeça. Pareceu sem jeito. Luise percebeu o rosto dela iluminado pelo leve sorriso de satisfação, demorando em seus lábios. viu e Claro que ela estava contente de ver o seu bom trabalho reconhecido. Quem não ficaria? Ainda mais por quem. Ele é um homem inteligente e muito-muito importante na cidade. Mas, naquela vez, a irmã Carmélia estava diferente...". Era mais que satisfação. Era alguma coisa... Alegria... Ah, não sei... A menina lembrava que, dividindo o espaço com o simpático professor a freira parecia deixar escapar alguma coisa forte que ficava pairando no ar. Uma espécie de energia que não podia ser vista, apenas sentida. Luise se lembra de ter pensado... Se ela não fosse freira e ele um homem casado... Que absurdo! Às vezes, sem querer, passa cada besteira pela cabeça da gente... Se a segunda série é a mais difícil... Por que Irmã Carmélia voltou pra a Espanha e deixou a gente no meio do caminho? Esquisito. Por que não deixaram terminar o ano? 
Vó Mina piorou. Não fala e nem reconhece mais ninguém. Luise não consegue estudar. Abre o livro na mesma página do nome escrito e circundado com lápis de cor, por ela outro dia. Alisa com as pontas dos dedos suavemente como se acariciasse a mão daquele que não é mais o namorado dela e o nome tremula antes de virar um pequeno lago rugoso, no seu livro de geografia. Reclina a cabeça sobre os braços cruzados em cima a mesa...

O homem está parado de pé à beira do caldeirão. A mulher chega silenciosamente e passa por ele. Despe o hábito e caminha nua para a água. Ele vai até ela. Mergulham juntos. A transparência da água permite ver o abraço. Não era a Irmã. Não era o Professor. Não era o caldeirão. Eram os vizinhos, com a porta do quarto, largamente aberta, em cima da cama desfeita, vistos pelo vão da parede-meia. Nus, o homem e a mulher pareciam desmaiados. Ha-ha-ha... "Fizeram bobagem." Não era o casal de recém-casados. Era um cavalo urinando no pasto.

Luise arde em febre. A cabeça parece que vai estourar de dor. A mãe faz litros de chá de erva-cidreira. Traz o prato de comida. "Fiz um franguinho." Luise tenta comer. Não consegue. Gosto estranho. Descobre que cozinhara pombo.

102

Numa madrugada, Vó Mina se foi. Partiu com a costumeira discrição. Sempre gostou de viajar pela manhã. Desta vez, não vai mais voltar. O dia é pesado. Por um lado, é gratificante e traz certo conforto ver a casa entupida de gente, mostrando o quanto Vó Mina era querida. Por outro, com tantas pessoas por perto, é impossível não sentir o desconforto da invasão na dor pessoal e intensa. Muitas delas, amigos e irmãos protestantes, frequentadores da Igreja Evangélica em frente ao jardim. Na hora da saída do corpo, chamam Luise para se despedir da querida avó. Apesar da insistência, a menina foi firme em não 
aparecer. Ela já tinha se despedido. Ninguém sabia. Muito antes de ser colocada dentro daquele horrível caixão de pano roxo. Aproveitou um momento que ficou com ela sozinha, na sala e falou muito tempo no último adeus a avozinha querida. Ela estava tão fria! Acompanhou o tempo todo o cortejo, carregando-a embora. Em pensamento. Sentada na soleira da cozinha. Não sendo a avó católica, foi poupada do lamentoso... 'Tem dó... Dó tem... Tem dó... Dó tem'... Repicado pelo sino da matriz até o fim dos enterros. A banda de música devia ser pior. A vovó era tão boa. Nada que a gente faz ou deixa de fazer impede alguém de morrer. Vó Mina fazia tudo direito e se foi. É muito difícil suportar o desaparecimento dela. A falta. $O$ buraco que ficou. De repente, na vidinha da menina o vazio, que nada preenche. Olha chinelinho dela, ainda ali... Com a manchinha de açafrão...

103

Catalão. Sertão goiano. Robusto. Não combina em nada com essa pasmaceira. Nas bocas, pelas ruas, comentários desanimados... "Goiânia tirou a expressão de Catalão". "Muita gente foi embora prá lá e ficou”. "A cidade patinha na estagnação". "Sugada". "Anêmica". "Desvitalizada". "Atolada no marasmo".

4 de abril de 1955. Jataí. 10 horas da manhã. Mais de mil pessoas esperando Juscelino Kubistchek para o comício. Mal o candidato chega, a chuva despenca. Alguém se lembra do galpão da oficina mecânica. Muitos correm, para lá, junto com o candidato. Simpático, bem humorado, ele deixa o povo à vontade. Da carroceria do caminhão, para lá de rodado, o mineiro discursa. "Desenvolvimento". "Transformação". "Fim da miséria". "Emprego". "Democracia". "Cumprimento da Constituição". Termina a fala hipnótica e se prontifica a responder perguntas. Silêncio. "Perguntem o que quiserem", insiste. O rapaz, próximo ao palanque, arrisca:

- O senhor disse que se eleito, iria cumprir rigorosamente a Constituição. Desejo saber então, se pretende por em prática o dispositivo da Carta-Magna que determina, nas suas Disposições transitórias, a mudança da Capital Federal para o Planalto Central? 
- Acabo de prometer que cumprirei, na íntegra, a Constituição e não vejo razão para que esse dispositivo seja ignorado. Se for eleito, construirei a nova Capital e farei a mudança da sede do governo. ${ }^{13}$

Assim falou Kubistchek. Aplausos! Gritos! Hurras! Euforia! Pergunta encomendada? Era a resposta que todos ali queriam saber. O sonho maior de Goiás ganhou seu par de asas.

Outubro de 1955. 36\% dos votos para aliança PSB-PTB. "Juscelino eleito Presidente da República". Vitória não por maioria absoluta. Cautela. "A UDN quer impugnar as eleições!". Preocupação. O Ministro da Guerra, lidera levante e garante a posse. "Ufa!”. A Constituição fixa o ponto para a construção da nova capital: "Planalto Central da República.” Especulação. Planalto goiano? Triângulo mineiro? Disputa. Tradição histórica favorece Goiás: o artigo $3^{\circ}$ da constituição de 1891 vem da emenda de Lauro Miller, fundamentada pelos argumentos de Francisco Adolfo Varnhagen favorável à construção da nova Capital no planalto goiano, na área demarcada pela Missão Cruls. Minas argumenta que boa parte do oeste de Minas ficava no Planalto Central, servido pela excelente rede ferroviária da Mogiana e da Oeste de Minas, lugar melhor para construir a cidade do que no planalto goiano, terras de cerrado, nenhuma estrada de acesso, distante mil quilômetros dos fornecedores de material de construção.

\section{4}

Nos últimos sábados, a menina tem ido, com mais frequência, ao encontro dos jovens, na casa do Sr. Cornélio. Hoje, tem muito mais gente do que nos outros dias. Ultimamente, o assunto mais discutido é a construção da nova capital. "Momento histórico da maior importância". Hoje, vai longe, o Gercílio chegou e entrou a discussão... "Estamos testemunhando a incorporação de Goiás ao processo produtivo do Brasil". "JK só tá colocando a cereja no bolo". "Não é bem assim, ele tinha a receita, mas precisou arregaçar as mangas e por a mão na massa. Que engraçado. “É fácil, colocar a ideia em prática, oferecendo benesses

\footnotetext{
${ }^{13}$ Trecho do livro Porque Construí Brasília, de Juscelino Kubitschek.
} 
à oposição, criando fatos consumados e queimando etapas." "Ele mesmo admitiu se apropriar do princípio básico das estratégias políticas do moralista francês Joubert, pra quem, 'não devemos cortar o nó que podemos desatar no jeito que achou pra viabilizar a construção de Brasília e levar adiante a ideia antiga." "No fim das contas, o mesmo de São Francisco: 'É dando que se recebe'... Ha-haha...". "Não se esqueça que foi outro santo que profetizou a construção da futura capital do Brasil: São João Bosco disse ter visto em sonho uma terra de riquezas e prosperidade situada próxima a um lago entre os paralelos $15^{\circ}$ e $20^{\circ}$ do Hemisfério Sul. Muita gente acredita que foi o sonho premonitório de Brasília. Pra gente, o mais importante foi o Israel acreditar... Ha-ha-ha... Lembra o susto?" Dez dias depois do projeto de lei, criando a Novacap no planto goiano e encaminhando ao Congresso, a notícia de que JK ia pra Uberaba... Centenário da cidade... Inauguração da exposição agropecuária anual... $\mathrm{Na}$ comitiva do Governador Ludovico, o prefeito Venerando, para representar o seu importante papel. Ele esperou Israel aparecer no hall do Grande Hotel e entrou no elevador com ele, levando um livrinho junto ao peito, de modo a ostentar o título, A Nova capital do Brasil, e o poderoso parlamentar não deixar de ver:

- Ô moço podia me emprestar esse livro?

- Dr. Israel eu tenho outro exemplar, pode ficar com este.

"Providencialmente, o organizador da coletânea incluíra a transcrição do sonho-visão e a foto de D. Bosco na abertura. De conhecimento geral a devoção fervorosa do parlamentar pelo Santo. O prefeito conseguiu colocar nas mãos dele o livro sem o carimbo de endereço certo e a questão da localização de Brasília ficou definitivamente resolvida". O poder de um livro... Conversa apaixonada deixa a menina cheia de empolgação... Preciso achar um jeito conhecer essa história toda, desde o início... Como eu ainda não sei... 
Segunda-feira, depois da aula... Atchim!, Luise na biblioteca, espirrando em cima de livros. Que papelada velha... Partes comidas, traças, cupins... Às vezes, nem dá pra ler direito. A menina copia um apanhado de informações no seu caderninho de fragmentos.

1. Século XVII. Brasil colônia. Primeiras idéias de se criar uma nova capital no interior, abrigada das invasões holandesa. Tiradentes, sugeriu São João Del Rei como nova sede do governo...

Quem diria... Nunca ouvi dizer que o mártir da Independência se interessou por isso...

2. Os ingleses aconselharam o Rei de Portugal a edificar uma Nova Lisboa no coração do Brasil.

Esses eram interesseiros... Não à toa ajudaram o Rei a fugir dos franceses e vir pro Brasil.

3. O marquês de Pombal propôs mudar a Capital do Império Português para do Brasil Colônia.

Fazia o que outros mandavam.

4. José Bonifácio de Andrade, o Patriarca da Independência encarregado de trabalhar no sentido da criação da capital propôs o nome o nome Brasil em latim: "Brasilia".

Ai, que lindo! Adoro saber de onde os nomes vêm... Na escola, comecei a aprender latim, francês, inglês... De repente, pararam de ensina, porque deixou de ser obrigatório. 
5. 1877. Francisco Adolfo de Varnhagen, historiador e diplomata, embaixador da Áustria, nascido em São Paulo, trabalhou em cima da ideia da mudança da capital para o Planalto Central. Aos sessenta e um anos de idade fez uma viagem reconhecimento ao Planalto, viajando de São Paulo a Formosa, às vezes, em "lombo de burro. Depois publicou o livro "A questão da capital: marítima ou no interior?", defesa robusta da interiorização da capital.

Parece que nas coisas mais importantes tem sempre livro. Esse Varnhagen passou pela terra da vovó... Sessenta e um anos... Será que vou viver muito?

Terça-feira... Atchim! Luise de novo na Biblioteca, continuando suas anotações.

6. De Londres, no fim do século XIX, Hipólito José da Costa defendia a ideia da transferência da capital do Rio de Janeiro para o interior do Brasil. O jornalista editava regularmente o "Correio Braziliense" ou "Armazém Literário" considerado o primeiro jornal brasileiro e publicava artigos favoráveis à interiorização da capital do país para uma área "próxima às vertentes dos caudalosos rios que se dirigem para o norte, sul e nordeste".

\section{O coração do Brasil é assim mesmo... Atchim!}

7. Proclamação da República. Constituição de 1891. A primeira inserção legal de Brasília: “...fica pertencente à União, no Planalto Central da república, uma zona de $14.400 \mathrm{KM} 2$, que será oportunamente demarcada, para nela estabelecer-se a futura Capital Federal".

\section{A ideia entrou na lei.}

8. 1982. O presidente Floriano Peixoto constituiu a Comissão Exploradora do Planto Central do Brasil, chefiada pelo astrônomo e geógrafo Luiz Cruls. 


\section{Lembro do Sr. Cornélio contar que esse homem depois de uma conversa qualquer com estudantes brasileiros lá na terra dele, resolveu mudar de vida e veio pro Brasil porque não devia estar satisfeito com a sua carreira de militar.}

9. A Missão chegou até Planaltina, antiga Mestre D'Armas, região mais central do país e delimitou a área do 'Quadrilátero Cruls', levando em consideração o trabalho de Varnhagen. Elaborou relatório minucioso da topografia, clima, hidrografia, fauna, flora, recursos minerais e materiais de construção encontrados na região. Depois que a zona de $14.400 \mathrm{Km} 2$ pré-definida pela Constituição foi identificada pela Missão Cruls, pela primeira vez a área conhecida como "Quadrilátero Cruls" no Planalto de Goiás, foi desenhada no mapa do Brasil.

\section{Que interessante! Atchim!}

Desde o início Luise ignora a falta de simpatia e finge não ver a cara fechada do Sr. Aluisio. A menina tinhosa ocupa outro fim de tarde, amolando o bibliotecário, com seus pedidos.

— Sr. Aluisio, Atchim! Será que ainda tem alguma coisa por aí que fala da ideia de construir Brasília?

— Volta amanhã. Qualquer coisa que encontrar, eu separo.

\section{6}

Seja porque quer se livrar dos espirros, seja por ver o esforço, o bibliotecário entrega para a menina uma folha de papel com vários dados, quando ela chega, no dia seguinte.

- Nossa, o Senhor ainda conseguiu descobrir tudo isso? Nem acredito!Muito obrigada Sr. Aluisio! Organizou por data, do jeitinho que eu 
queria. Vou sentar e ler isso já! Melhor mesmo é passar logo pro meu caderno...

10. 1905. O senador Nogueira Paranaguá, com o auxílio de escritores $e$ jornalistas, retoma a Campanha Mudancista.

\section{Entrou na Constituição e parou.}

11. 1922. No centenário da Independência, sem poder comparecer pessoalmente, o presidente Epitácio Pessoa cumpre Lei do Congresso Nacional e manda afixar a pedra fundamental da futura Capital dos Estados Unidos do Brasil em Planaltina, no quadrilátero escolhido e demarcado trinta anos antes.

\section{7 de setembro... Meio dia... Pena o presidente não ter podido participar dessa comemoração tão importante.}

12. '1934. Promulgada a segunda Constituição da República com o artigo $4^{\circ}$ das Disposições Transitórias mencionando vagamente a transferência da nova Capital para "um ponto central do Brasil".

\section{Vagamente, por quê?}

13. 1937. O clima de guerra civil iminente no país propicia o "Golpe de Estado" e Getúlio Vargas cria o "Estado Forte" e outorga nova Constituição que apenas aborda a questão da mudança da Capital.

\section{Atchim!}

14. 1945. O Instituto Brasileiro de Geografia e Estatística emite parecer favorável à interiorização da Capital do Brasil e justifica como "Questão de segurança nacional".

\section{Ganhou importância!}

15. 1946. Fim do "Estado Novo", a $4^{\circ}$ Constituição promulgada diz que a Capital da União será transferida para o Planalto Central”. 
Sem dizer aonde, no Planalto Central, deu motivo pra disputa: "No Planato goiano!" “No Triângulo Mineiro!” Teve até quem quisesse a capital do Brasil "Em Goiânia recém construída!” Ainda bem que o Quadrilátero Cruls ganhou.

16. 1948. O Presidente Eurico Gaspar Dutra nomeia Comissão de Estudo de Localização da nova Capital, presidida pelo General Djalma Poli Coelho. O relatório final apoia a proposta da Missão Cruls com a área sugerida acrescida de 52.000 mil quilômetros quadrados estendida na direção de alguns rios que deveriam funcionar como limites naturais. A nova área escolhida pelo Congresso Nacional é denominada "Retângulo do Congresso" e encaminhada ao presidente Dutra com a mensagem que ficou conhecida com "Mensagem de Corumbá.

Então foi desse General que veio o nome: “Missão Poli Coelho".

17. 1952. O congresso Nacional aprovou a Lei que mandou realizar estudos definitivos para a escolha, de um sítio para a nova Capital Brasileira no Planalto Central.

Por que será que não disseram logo: "No Quadrilátero Cruls"?

18. 1953. Getúlio Vargas determina que a Comissão de Localização da Nova Capital realize estudos definitivos e o presidente da comissão, General Aguinaldo Caiado de Castro, contrata a empresa, Cruzeiro do Sul, para fazer o levantamento aéreo-fotográfico da região do Planalto Central e a firma Donald J. Belcher e Associates para a interpretação das fotografias aéreas.

\section{Estudos importantes.}

19. 1954. Depois do suicídio do presidente Getúlio Vargas, o Vice Café Filho assume a Presidência e a Comissão de Localização da Nova Capital Federal passa a ser presidida pelo Marechal José Pessoa Cavalcanti de Albuquerque, que constituiu a Subcomissão de Planejamento Urbanístico, composta pelos arquitetos Raul Penna Firme, Roberto Lacombe e pelo engenheiro civil José de Oliveira Reis, que elaboraram um estudo preliminar para a nova 
Capital, trabalhando em primeiríssima mão com o material fotográfico para o 'sítio castanho' definido entre cinco opções existentes.

\section{Ano do suicídio... Pouco tempo atrás...}

20. 1955. A Subcomissão de Planejamento Urbanístico elabora estudo preliminar para a Nova Capital, projetando e apresentando a cidade de Vera Cruz ao General Pessoa.

\section{Brasil-Brasília. Prefiro assim.}

21. 1955. Eleito, Juscelino organizou instrumentos para transferir a capital, estabeleceu a construção de Brasília como meta-síntese do seu plano de Metas e criou a Companhia Urbanizadora da Nova Capital - NOVACAP.

\section{Alcançou a gente no tempo é só acompanhar.}

É possível que o interesse real da menina tenha despertado o interesse do bibliotecário, que se mostra disposto a ajudar.

— É trabalho pra escola?

- Não senhor.

- Por que quer tanto saber sobre isso?

— Pra nada, não... Quer dizer... Só pra aprender mesmo.

— Uma pessoa tá desenhando os prédios... Foi escolhido num concurso... Tem um jornal aqui...

— Que bom, muito obrigada!

22. 1956. Lançado o edital do concurso. 63 inscritos. 26 propostas apresentadas. 5 satisfazendo os critérios. A vencedora é a proposta 22 elaborada por Lucio Costa. Na Ata da Comissão Julgadora: o projeto era "o único para uma capital administrativa do pais. Juscelino eleito constituiu a Comissão de Planejamento da Construção e Mudança da Capital Federal. A definição do lugar deu ensejo a uma serie de articulações, até decidir-se pela realização 
do concurso público nacional com júri internacional para a escolha do projeto a ser implantado.

Prédios... Devem ser tantos... Aqui, até agora, a gente só tem o "Dentinho".. Sozinho no meio das casas, foi logo chamado assim.

- Pronto, Sr. Aluisio. Acabei. Muito obrigada. Não podia imaginar tanta complicação e gente envolvida na construção de Brasília.

— Não foi coisa fácil...

\section{7}

Catalão, animada. "Agora é pra valer!" "Wagner Estelita Campos preside a comissão do Orçamento da Câmara". "Chegou hora de ligar Catalão e Brasília". "A oportunidade de integrar o município aos grandes centros econômicos do país." O deputado federal é atuante. A cidade sabe disso. Anos atrás, ele diretor do Dasp e o professor Antonio Miguel Jorge Chaud, prefeito de Catalão, juntaram forças e trouxeram para a cidade grande conquista no campo cultural. No Plano Nacional de Erradicação do Analfabetismo, a determinação de escolher uma cidade, em cada região do país, para a implantação de novos métodos de aprendizagem escolar e adoção de treinamento em caráter experimental. No Centro-Oeste, Catalão eleita, abriu os braços para receber professores, médicos, sociólogos... Toda uma equipe cultural que veio estudar a região, com o propósito de aplicar métodos adequados, na criação de escolas rurais e novos grupos escolares urbanos. Agora, a menina dos olhos do deputado é a ponte sobre o Rio Paranaíba. "Vitória!" "Estelita conseguiu incluir a verba no orçamento da União". A rodovia vai ligar São Paulo, Minas Gerais e Goiás à futura capital do Brasil, Brasília, e a construção da ponte vai evitar que a BR 050 passe por Araguari, dê a volta por Goiandira, Arizona, Brasília e, na rota, a Catalão-Cristalina ligando Belo Horizonte a Brasília. Com ela, os caminhões 'fenemê' que saem de Catalão levando manteiga, charque e açúcar para São Paulo e Rio de Janeiro não vão mais ter que dar a volta por Goiandira, Cumari, Nova Aurora para chegar a Araguari e 
levar três dias em estrada de terra até Campinas, quando começa a estrada asfaltada até São Paulo. Levar na volta tempo igual, no mesmo percurso, carregados de mercadorias variadas para serem revendidas aos comerciantes em Catalão. "Finalmente a cidade vai se livrar da pecha 'Catalão do cotovelo' que carrega desde que a Estrada de Ferro foi desviada para Goiandira.”. Parece tudo uma maravilha... Tomara não abandonem a boa estrada de ferro... Tanto trabalho, dinheiro e sofrimento na construção da linha do trem, não pode ser desperdiçado.

Will they occur,

These people with torsos of steel

Winged elbows and eyeholes

Awaiting masses

Of clouds to give them expression, These super-people!- - - ${ }^{14}$

De repente, Catalão invadida... A BR-050 avança até a cidade, trazida pelas máquinas, e tratores Carterpiller... Dinossauros de ferro enormes, rasgando a terra e escorraçando os bichos! A inauguração, grande acontecimento: o Presidente calorosamente recebido debaixo do temporal. $\mathrm{O}$ aguaceiro não esmorece o seu entusiasmo. Não quer alterar a solenidade. No palanque improvisado do novíssimo Posto JK, Juscelino fala ao povo, desejando que as bênçãos de Deus jorrem sobre a lendária e querida Catalão, como a chuva torrencial jorra sobre a cidade.

A rodovia impulsiona o aparecimento de postos de gasolina, oficinas mecânicas, caminhões, ônibus e carros na cidade... Novinhos. Levas de trabalhadores chegam de várias partes do Brasil. Pessoas em trânsito em busca de oportunidades de trabalho. Candangos que vão ajudar a construir Capital Federal. A gente de fora traz novidades para os habitantes. Costumes diferentes chegam às

\footnotetext{
${ }^{14}$ Primeiras estrofes do poema "Brasília" de Silvia Plath.
} 
vezes de cidades possuidoras de maior poder aquisitivo, modificam costumes, criam novas atitudes, valorizam produtos da terra. A cidade começa a se transformar. No meio dos que gostam, os que não aprovam. "Essa influência toda não vai dar certo". "Lá se vai o nosso jeito de fazer as coisas". "Quem pode segurar?" Vai-e-vem... Zum-zum... O português falado de diferentes maneiras e em sotaques diversos - chiado, cantado, rascante, mordido - às vezes parece outra língua. Efervescência nos crescente: negócios: moradias levantadas, vendidas, alugadas, empregos novos. Zé Luiz chega numa dessas levas. Trabalhando na estrada, o cunhado trouxe a família e escolheu a cidade para morar por uns tempos. Alugaram casa ótima na Rua Bernardo Guimarães. O rapazinho é bem aceito pelo grupo de Luise. Mesma idade dela. Tornam-se bons companheiros. Quase namoradinhos. Saem com a turma. Os dois sempre juntos. Ele é habilidoso. Deu de presente dois pares de sandálias para ela que ele mesmo fez... Lindas, macias e confortáveis... Uma azul e uma preta. Na amizade dos dois, leveza, carinho, serenidade. Durante o tempo que ficou. Nenhuma desavença. Na véspera de ir embora, despediu-se com uma serenata tão linda! Ótima pessoa. Sempre. Luise guarda boas lembranças dele. O flerte não deixou marca. Nos primeiros dias, falta, saudadezinha e só. Diferente da Ivone que namorou o Chico, irmão dele. Para desespero da avó dela, que desaprovava e agora não sabe o que fazer para aliviar a dor de cotovelo da neta que ficou para trás, apaixonada, suspirando pelos cantos.

109

No sábado depois que o Zé Luiz foi embora, Luise volta à casa do Sr. Cornélio. Encontra o poeta-escritor, do lado de fora, conversando com um respeitado médico da cidade e com um importante político.

— Boa tarde, Luise. O pessoal tá lá dentro. Fica a vontade.

- Obrigada Sr. Cornélio. 
A menina senta na mureta do alpendre e pode ouvir o político, recémchegado da capital, dizendo que quis dar logo um giro pela terra natal, passou pela porta do amigo e não resistiu em saltar do carro... "só pra cumprimentar e dar 'dois dedos de prosa', volto depois pra conversar com calma".

Um ronco no céu, pescoços estirados para o alto. O médico cogita... "Pode ser o Presidente..." O político toma como certo que é pergunta para ele... "Juscelino não tira os olhos da construção. Fiscaliza uma ou duas vezes por semana. Fala da cidade como sua terceira filha: Márcia, Maristela e Brasília”.

Luise vê avião passar... Pena que só um teco-teco ou outro desça de vez em quando no nosso campo... Apoiado na porta do carro, o político conta um caso.

"O homem passa muito tempo no ar. Não tem medo. Encomendou até um avião mais rápido. Quando era governador, viajava no "Mate Sete", conhecido assim por causa do número de passageiros que cabia nele. Lembro do Affonso Heliodoro contar lá no Liberdade que voando uma vez de Mantena pra Belo Horizonte o cacareco quase caiu,... Chefe da Casa Militar, Affoso foi convocado na cabine para dar uma mãozinha ao piloto Miltom Prates, naquele dia, sem copiloto. Sentado ao lado do Miltom, um dos motores parou, o avião começou a perder altura, e o piloto experiente identificou logo a pane. Esquecera de abrir um dos tanques de combustível... Ha-ha-ha... Foi muito engraçado... Ha-ha-ha... O Affonso contando essa história...

O Miltom gritava: "Abra a válvula sô!" Eu respondia: "Que válvula, sô?" "Essa daí do seu lado, rápido, sô!” Válvula aberta. Combustível abastecendo o motor. Juscelino, que estivera dormindo, irrompe na cabine de pijama: "Que escarcéu é este?" Eu respondi: "Foi o avião, Governador, quase íamos pro chão." E o Juscelino: "Ora, tenham paciência, gente! Vão amolar o boi!" Voltou pra cama.

Os três caem na gargalhada... O médico diz "O homem é corajoso...., diz o médico. O Sr. Cornélio emenda: "Habilidoso também... Contam que num almoço, percebendo o constrangimento de alguns convivas, largou os talheres 
com que vinha destrinchando o frango e disse: 'Lá na minha terra, a gente come frango é assim, ó...”. Pegou o pedaço com a mão, levou a boca e voltou a comer tranquilamente. Deixou todo mundo à vontade e o encontro foi um sucesso"'. Os homens esquecem a pressa quando o Sr. Cornélio convida os amigos a uma reflexão.

- Certas coisas acontecem e deixam a gente pensando... Aquele Cruls... Conversando casualmente com estudantes brasileiros lá na terra dele, percebe oportunidade de largar o exército e vir para o Brasil sem precisar prestar contas a ninguém. $O$ belga não tinha noção da transformação que a atitude dele iria provocar. Tem coisas... Sei não... Vejam bem... Na viagem de vapor, o homem conheceu Joaquim Nabuco no início da carreira diplomática podendo ajudá-lo a se aproximar do Imperador e das famílias cariocas tradicionais... A República veio e Cruls conseguiu o financiamento pra fazer a expedição com o Presidente...

\section{Engraçado... Esqueceram a pressa.}

- Seria destino do astrônomo Luís Cruls nomear e liderar aquela expedição integrada por médicos, geólogos, geógrafos, botânicos naturalistas, engenheiros, higienistas... Fazer o levantamento da topografia, clima, geologia, flora, fauna e o recursos materiais da região do Planalto Central...

- Parece que levava o negócio a sério... Era escrupuloso. Relatava tudo que descobriam. Lembrava sempre que usavam dinheiro de uma nação. Pela primeira vez uma expedição foi toda registrada em nosso território.

O médico interveio.

- Quando eu estudava no Rio de janeiro, conheci um Morize na Faculdade Nacional de Medicina descendente da família do médico e pintor Henrique Morize, o sujeito que tirou a maioria daquelas fotografias.

Nesse ponto, o Sr. Cornélio não resiste e dá sua opinião de conhecedor. 
- E tinha o que fotografar... imagina só... A saída do Rio de Janeiro, passando por São Paulo, São José dos Campos, Campinas, Casa Branca, Ribeirão Preto até Uberaba, a estação final da linha da Mogiana.

- Ehê viajona! De Uberaba, o grupo em lombo de burro, percorrendo 4 mil quilômetros, com quase 10 toneladas de equipamento, dormindo em barracas de lona cedidas pelo Exército, passando por Uberlândia, Araguari, Catalão...

Luise se enche de orgulho. Primeiro os bandeirantes... Depois essa expedição... A nossa cidade é mesmo a porta principal do Estado de Goiás!

$\mathrm{Na}$ medida em que o Doutor Martino vai citando as cidades por onde o grupo de Cruls tinha passado... “...Ipameri, Pires do Rio, Silvânia, Goiás Velho, Pirenópolis..." a menina vai reconhecendo os nomes... Eu e vovó passamos por algumas dessas cidades na nossa viagem pra Formosa...

A discussão se envereda para a política. Luise pouco entende. Acha que às vezes o político... 'Puxa a brasa para a sardinha dele' e começa a falar empolado como se tivesse num palanque. "Boneeeca cobiçaaaada..." A voz modulada vem de dentro da casa. Vendo que Gercílio está começando a ouvir os calouros, os amigos se despedem, combinando novo encontro. Luise assiste um pedaço do ensaio e volta para casa... Sempre que venho aqui, aprendo coisas interessantes.

"Telefone em Catalão?” “Maravilha!" "Estão selecionando telefonistas.” Alguns meses

depois das primeiras notícias, o padrasto de Luise chega em casa com a novidade. "Compraram mais uma mesa telefônica. Vão precisar de outra telefonista. Dei o nome da Luise." Um dos diretores da nova companhia é sócio da charqueada e preza muito o Sr. Esteves. Entrevistada pelo gerente da Companhia Telefônica de Catalão - CTC, a menina sai de lá empregada. Quatorze anos de idade. Para de estudar. Primeiro dia de trabalho. Sentada diante da mesa 
telefônica... Faz lembrar um piano, no lugar das teclas... "Chaves, pegas, lâmpadas, buraquinhos dos circuitos, tudo tem correspondência." Edwarda na mesa ao lado ensina o serviço. "As lâmpadas e os circuitos enfilleirados no painel à frente correspondem aos números dos telefones instalados na cidade.” Primeira telefonista a ser contratada, Edwarda assume a postura de chefe. "Quando alguém tira o fone do gancho, a lâmpada acende, a telefonista introduz a pega no buraco correspondente, vira a chave e pergunta: 'Qual o número, por favor?" A voz dela é enfadonha. "O assinante informa, a telefonista pede 'Um momento, por favor,' introduz o par da pega no circuito correspondente ao número solicitado e puxa a chave para acionar a campainha do telefone." É tudo muito mecânico. "Quando a luz apaga, é sinal de que o telefone foi atendido. A telefonista deve voltar a chave para a posição normal e se retirar da comunicação. Quando as duas lâmpadas voltam a acender indicam que os dois aparelhos foram recolocados no gancho, e as pegas devem ser puxadas. Numa conversa mais demorada, a telefonista tem a obrigação de virar a chave a certos intervalos e verificar se a comunicação flui normalmente.”

Quando Luize vai para casa, passa pela sapataria e namora o par de sapatos brancos na vitrine... A primeira coisa que vou comprar, quando receber meu salário. Desta vez não vai sumir da vitrine, como a bonequinha.

\section{1}

Por conselho das amigas, e insistência do próprio... "Quer ir ao cinema comigo?" Luise resolve dar uma chance ao Danilo. Encantadas por ele, elas diziam: "Moreno." "Forte." "Bonito.” "Um rapagão!” Não me impressiona... Por quê? Mesmo assim, quem diria... Foi ele a colher o primeiro beijo da menina. Numa noite, depois do cinema, ao deixá-la na porta de casa, surpreendeu com o repentino roçar de lábios, levíssimo. Então, isso é que é beijar? Coisa mais sem graça. Esperava que um dia acontecesse. Do jeito que leu. Cadê as estrelas? Distanciadas no céu nublado. Nenhuma piscando. O tempo fechou. A mãe espiava pela greta da janela. Arrochou. Por conta da leve bicota. Luise 
forçada a casar? Ai-ai... O Danilo parece gostar mesmo de mim. Por que não consigo olhar pra ele do jeito que olho pro Auro? Acho desperdício, o gostar aparecer tantas vezes desencontrado... Pensando nisso, lembro o rapaz bem apessoado que chegou à casa do tio Eufrísio, naquela manhã, montando belo cavalo e falou pra Ana que passando por ali a galope pra sua fazenda, sentiu qualquer coisa entrar em seu olho. "Deve ser um cisco". "Não consigo enxergar nada... Será que dá pra tirar? Tá incomodando muito". Ele perguntou pra Ana, e ela pediu para mim. "Luise dá uma olhadinha e vê se consegue tirar". Fui na mesma hora, pensando, Coitado! O moço sentou no banco e ficamos cara a cara. Examinei o olho e não vi nada. Pediu que eu abrisse a pálpebra. Fiz isso com todo cuidado. Ele revirou a bola negra pra todo lado. Eu disse que não via cisco algum. Ele insistiu: "Sinto qualquer coisa arranhando... Pode procurar melhor desse lado?" Repuxei a pálpebra de novo... Olhei... Olhei... "Ué, eu não vejo nada, não". Ele garantindo que alguma coisa havia de ter, e os meus olhos não enxergando nada. Desisti de procurar. Ele ficou sem graça. Despediu logo. Foi embora. "Não tinha nada no olho dele não, Ana". "Eu sei, Luise... ele inventou aquele cisco só pra vir aqui te conhecer e ocê nem reparou". Surpresa. "O cisco, desculpa!?" Mal acreditei. Cheguei perto dele só pra ajudar e sem perceber o esforço do moço. Na época, eu só queria brincar. Hoje, penso... Se ali pertinho do fazendeiro, visse o seu olhar diferente... Correspondesse... Entrasse no jogo... Participasse da trama... Quem sabe hoje eu seria uma fazendeira em Goiás... Já pensou? Quem manda no sentimento de uma pessoa pra outra? Ninguém. $O$ pedido do corpo da gente não é igual pra todo mundo. Mistério. Não senti nada por ele a não ser pena por causa do cisco. Diferente do Auro, logo que vi... Ah. O Danilo quis logo ficar noivo. Chegou a comprar par de aliança, coitado... Não ia dar certo. O primeiro beijo pôs fỉm ao breve namoro. Gostava dele apenas como bom amigo. No coração e na cabeça da menina, Auro continua ocupando o lugar. 
Na rotina do trabalho há mais de um ano, Luise vira a chave de uma ligação mais demorada. "...o cheiro do cabelo." Captura fragmento da frase fora do comum e leva susto! Não é possível. Apreende outro... "A doçura da voz penetrando..." Que conversa mais esquisita é essa? A menina sabe de quem são os telefones e quem fala com quem. Não pode ser! Entre um chamado e outro... "Numero, por favor?" "Um momento, por favor.", não pega frase inteira. “...momentos de felicidade inimaginável.” Conversa murmurada. Difícil de ser compreendida. Palavras. Sussurros. Lembram gritos contidos. Luise não entende nada. Pode ser que estejam lendo poesia. Não quer despertar a curiosidade de Edwarda. Nos horário comercial, duas telefonistas trabalham ao mesmo tempo. Retorna discretamente a chave para a posição vertical. Evita ruído que denuncie a sua presença na linha. Passa o resto do turno, perturbada. A ligação dura uma eternidade. Nos momentos de fluxo lento, Edwarda, do lado, fazendo confidências e falando sobre o Marluz. Está loucamente apaixonada por ele. "Sei que ele é bem mais moço do que eu, mas a gente não manda no coração.” Luise sabe que o rapaz está interessado na Lélia. Entre quem mal acaba de conhecer e a amiga de tantos anos, a menina não tem dúvida. Claro. Torce mesmo é pra segunda. Por que alguém gosta de alguém, que gosta de outro alguém, que gosta de outro... Será sempre esse inferno?

O tempo passa. O turno varia. Luise pega parte da noite. Cumprindo o dever de fiscalizar as ligações mais demoradas, passa a ouvir os fragmentos da conversa sussurrada, com a maior curiosidade. Todas as noites, no mesmo horário... "como o sol e a lua, de vez em quando...” Entre uma chamada e outra... “...passarinho, voaria agora e iria pousar na janela.” ...captura partes das frases sussurradas. “...iluminados pela mesma luz." "A lua vê alguém, que eu queria tanto ver” Eta conversa esquisita! "O que vai ser amanhã" "suportar" "alma gêmea" "afinidade." “...ninguém que combinasse tanto" “o dia todo" "Eu também” "está sempre comigo." “Ooooh... Não! Não é verdade.” Luise já não se perturba tanto. Parece coisa de filme! Deixando o trabalho à noitinha e caminhando para casa... Já não bastam meus problemas? Por que tinha que tomar conhecimento do segredo deles? Soubesse a vovó disso, o que diria? Nunca vou saber. Mesmo 
que não estivesse doente, acho que não contaria nem pra ela. Não suporta mentiras, intrigas, falatórios... Como poderia contar uma coisa dessas? Luise não é mexeriqueira. Além disso, sabia que o assunto era grave demais para ser comentado. De agora em diante vou ter que carregar esse peso, sozinha. Dependesse só dela, o segredo estaria garantido. Todos têm seus mistérios. Ao atravessar o jardim, passa pela "Pulguinha" e o filho do farmacêutico, agarradinhos, num banco. Ai-Ai... Tá aí outra coisa que pode dar problema. Aqui, as mocinhas não costumam namorar desse jeito, não. A família veio morar na cidade há muito pouco tempo... Ela, miudinha... Cinturinha de pilão... Mal chegou e ganhou o apelido. Pulguinha entrou há pouco na escola. Não conhece os costumes daqui. Namorando desse jeito... Ah, isso não vai dar certo.

$$
113
$$

Com o tempo passando, Luise percebe tensão crescente nos fragmentos e poucas frases completas que consegue capturar. "Na lembrança...” “...tudo em meu pensamento, em minha vida." "Estou toda trêmula, só de falar". "Penso o tempo todo..." "A lembrança me desespera." Mesmo que não entenda a menina não tem dúvida de que a coisa é muito séria. ...líquidos misturados..." “...molhadinha.” Não quis tirar. "Sentir perto... Queria ser sua toalhinha. " “Ainda sinto em mim..." "Ilusão”. "Não.” “...rígido, causa dor.” Isso é muito perigoso! A moça está enredada.“...linda, iluminada pelos foguetes!” Luise fica triste. “Tremi e empalideci...” Sente pena “...muito mal..." "Mamãe chegou a chamar o médico." "Precisava ficar tão distante?" "Quase morro só de pensar que daqui a pouco, vai estar..." "Por causa das crian...". Ela pertencia a uma das famílias mais tradicionais da cidade. Ele a outra. Ambas teriam motivos para se orgulharem com a união dos dois, exceto pelo fato dele já ser casado e pai de vários filhos! "O casamento foi um erro." Um erro... E ainda dizem que casamentos são arranjados no céu... Pois sim! O da minha mãe com meu o pai foi? O da mãe Estela com o pai dela também não foi. "Você é tão poderoso... Por que não 
arranja um jeito?" "Sim, sim, meu amor! Tudo o que você quiser."Que jeito meu Deus? Fugir? Matar? Não, não. Não quero nem pensar nisso. Luise fica ainda mais triste. "Não tenho sido capaz de fazer nada". "É como se estivesse vivendo um sonho terrível." "Entro num novo ano com o coração estraçalhado". "...fugir pra bem longe". "Você sabe que eu não..." "Mamãe anda desconfiada." "Sonhos". "Pressentimentos". "Não dá pra continuar assim." "Assim, não vale a pena viver." "Não fossem os...". "Não duvide." “A ponta da saia dobrou. Apareceu um pedacinho da coxa. Quis colher a rosa na hora". Parece que entraram numa ratoeira. Têm coisas que não dá para entender... Como pode uma moça bonita, mimosa e cheia de vida como ela não arranjar namorado que a mereça? Será verdade que os rapazes têm medo de moças bonitas e inteligentes? Tantas outras mais feias, na idade dela... Se ficar nessa... Tantos casos servem de exemplo... Não tem muito tempo, a filha do Sr. Menelau se envolveu com o jogador de futebol de outra cidade... O pai dela chamou o genro e exigiu que exercesse o direito de marido... "Legítima defesa da honra!" Senão ele mesmo faria. O marido matou a mulher. O pai dela pode andar pela rua de cabeça erguida e encarar os clientes. "A 'moral' e os 'bons costumes' têm que ser preservados." Casada ou solteira, a mulher paga a conta. Com sangue. Ou humilhação. Aquela mocinha que passou lá na frente de casa, perdida como um passarinho que caiu do ninho...

\section{4}

A lembrança da menina reconstrói o dia em que escutou a mãe e a vizinha cochichando, na janela, sobre alguém que passava pela rua. "Essa aí se perdeu com o namorado." Curiosa, a menina foi ver quem era. Alcançou a porta no momento em que a mocinha passava cabisbaixa pela frente da casa. Carregava trouxa pequena. Parecia tão envergonhada! Atraída, talvez, pela força dos olhares das duas meias-caras cravados nela, a mocinha levantou a cabeça e Luise pôde ver o seu olhar tristonho, por um instante. "O pai soube e expulsou de casa, na hora." "Vai morar na casa da Nina." No limiar da porta, sem ser vista pelas 
tagarelas, a menina vê pessoas virando rosto na rua e passando ao largo. Afastam dela como se tivesse doença contagiosa. Credo! Qual a diferença entre essa mocinha e os leprosos obrigados a viver naquelas cabaninhas de pano à beira da linha, longe de todo mundo? Coisa mais triste... Tratada desse jeito depois que o namorado terminou com ela... Condenada pelo próprio pai a viver longe da família... Obrigada a ser "mulher à-toa pra viver... A morar na casa da Nina... Até a dona de casa de mulheres livres tem cuidado danado para evitar que as filhas fiquem faladas. As duas vivem resguardadas na casa a avó e são vigiadas de perto pelo tio. Ida, a mais velha vai sempre aos sábados à casa do Sr. Cornélio ensaiar para se apresentar aos domingos no programa de calouros. Canta bem. Nunca é buzinada. Está noiva e não demora a casar. Nívea, a mais nova é enjoadinha, boboca e ciumenta com aquela mania de querer afastar a Lélia de todo mundo para ser só amiga dela. Na janela, as mulheres continuam comentando. "E a Coralice, heim?" "Ah, não dá pra comparar a Coralice com essa mocinha aí. É diferente. A Coralice fez o que fez porque quis." "Escolheu ser "mulher da vida, de propósito." "Tava decidida". "Não escondia a intenção." "Dizia que ia fazer isso, aprontar aquilo, ninguém acreditava até um dia rolou mesmo com um moleque qualquer, lá no pasto do Pedrinho. "Não era namorado e nem nada." "Que frieza." "Foi embora para Anápolis, morar numa casas de mulheres e não se despediu de ninguém". "Ela não era boba de enfrentar o desprezo da cidade." "Escolheu caminho próprio." “ "Não dá pra imaginar a Coralice mais triste do que era depois do que fez."

Luise escuta e pensa... Talvez a "Coroista" ainda venha conhecer alguém... Gostar de alguém... Não é impossível. Aconteceu com a Amélia Nazar. Pobre ou rico, expulsar a filha de casa é o menos que se espera do pai de qualquer moça que "se perde" por aqui. O pai da Amélia não fez diferente. Ela foi morar em Campo Grande. Lá, com o tempo, passou a comandar uma casa de mulheres livres. Conheceu o Antero. Convenceu o poeta de Jataí a vir morar com ela aqui. Talvez quisesse mostrar ao pai que, apesar de tudo, podia viver na sua cidade natal como qualquer "mulher direita". A Coralice, custosa do jeito que é, pode até comandar uma casa assim, um dia. “A Tita tá em Anápolis, também né?" “Trancada num convento, contra a vontade." "O pai tem medo de aconteça isso com ela". Coisa injusta. Prendem a menina lá e tomam como certo que ela tá livre da praga da 
madrinha. A Tita e a Coralice, morando em Anápolis... Uma no convento. A outra numa casa de mulheres. Será que um dia, as duas vão se encontrar... Por acaso... Na mesma rua... Vão se olhar... Se reconhecer... A Tita indo pra missa, contando contas do seu rosário... Custa tanto a acabar! Às vezes, senta e chora um pouco... A Coroista sem ligar nada pra esse negócio de igreja, voltando pra casa pra dormir. Sorriso fingido. Parte da profissão. Nunca escolheu namorado. Agora é que não escolhe mesmo. Nossa, que vida danada deve ter as duas!

$$
115
$$

Depois de dois anos de trabalho. Férias! As primeiras. Luise empolgada com a proximidade. Pensando nisso, entra automaticamente na linha de uma ligação mais demorada. "Como tá ele hoje?" Escuta a voz melosa da Pulguinha fazendo perguntas para o namorado. Ele, que ele? Pergunta estranha. Bobeira. "Ele sentiu falta de mim?" Ele, que ele? Que enjoamento. A ligação flui perfeitamente. Luise sai da linha sem ouvir a resposta. O programa Peça a sua música está começando. Explodem pedidos de ligação para a Rádio Cultura. "Número, por favor?" Luise está ansiosa pelas férias. "Um momento, por favor." A Pulguinha e o namorado são logo esquecidos. Em breve, vou ter um descanso da lenga-lenga da Edwarda e do nhê-nhê-nhê da Pulguinha.

Não demorou muito, Luise viu a "Pulguinha" de barriga crescida e compreendeu a que "ele," a namoradinha se referia, naquele dia. O resultado não surpreende. O namoradinho desapareceu. Os comentários varrem a cidade. "Foi estudar na capital.” "O tio levou.” "É um importante político, lá." Exemplos mostram. Casos como esse têm sempre o mesmo fim. O rapaz poupado. A moça pagando a conta. 
Outubro aproxima. Movimentação. Hora de construir o ranchão. Reformar caixas. Bordar capacetes... Cocares... Chapéus... Fazer novos uniformes. Ensaiar. Deixar tudo pronto, e todo mundo livre para ir pra igreja quase o mês inteiro. Rezar para a Virgem do Rosário. Louvar a padroeira. Pagar promessas Fazer pedidos.

Está chegando o dia

Está chegando a hora

De cantar e bater caixa,

Pra louvar Nossa Senhora

Primeira sexta-feira de outubro. Luise é acordada cedinho... A festa já começou. O batuque da Alvorada, tá avisando todo mundo.

O batido dessas caixas

Anuncia tradição

Começou a nossa festa

Na cidade de Catalão

Os ternos todos saindo dos pontos de ensaio... vestindo a cidade de cores... indo pro ponto de encontro... Daqui a pouco todos lá... no Largo do Rosário... o apito zunindo e dando início ao espetáculo... Cor... Dança... Cantoria... Religiosidade... Fé... Todo mundo por perto contagiado. Depois da apresentação, os dançadores vão tomar o café da manhã servido pelos festeiros e pelo pessoal da comissão da festa. Tradição. Fartura. Domingo passado foi o último ensaio da Congada. De hoje em diante é missa a semana inteira na capela. De noite. Não posso perder. O Pedrinho entrou pro Terno do Pio. Quero ver como dança. Gosto do Pedrinho. Dos filhos do Sr. Esteves, me dou melhor com ele. O Berico é bem mais velho. A Tita nem digo nada.

Luise conhece Joãozinho. O rapazinho é de Goiânia. Coincidentemente, em férias do trabalho. Aproveitando para conhecer a cidade. "Sempre tive vontade de assistir a festa". Conversador. Fala da novidade da televisão. "Assis 
Chateaubriand quis implantar um antena retransmissora em cada cidade grande. Comprou dez estações. O canal 7 de Goiânia, TV Rádio Clube, retransmite programa da Rádio Tupi”. Luise tenta imaginar imagens movimentando dentro das caixas, nas casas das pessoas. Pequenos cinemas? Joãozinho conta coisas que estão acontecendo pelo mundo. "O Rock And Roll é o ritmo do momento." "Elvis Presley entrou numa gravadora, pensando em gravar um disco pra a mãe e foi descoberto, agora estoura nas paradas se sucesso." "O jeito dele cantar é mesmo diferente!" "Mistura tudo quanto é tipo de música." "Ninguém resiste." "No filme, faz todo mundo se levantar e requebrar dentro do cinema". "Sabia que Elvis começou a ganhar a vida como motorista de caminhão?” Joãozinho traz muitas novidades. "Juventude Transviada." Fala... Fala... Fala... "O topete e a jaqueta vermelha do James Dean.” Luise, encantada, imaginando corrupios no mundo, misturando ares, mudando usos, transformando, costumes. Ela percebe as coisas começando a mudar. No cinema, Brigitte Bardot é a sensação do momento, quebrando tabus... A Ivone agora só fala fazendo biquinho para imitar a atriz de "E Deus criou a mulher" Se acha parecida com ela. Se não tivesse o nariz de batatinha e fosse um pouco menos rechonchuda... Talvez parecesse mais.

\section{7}

Luise conta para Joãozinho como é a festa. "A origem da congada é contada de diferentes maneiras. Mas todas concordam que a Virgem do Rosário já era venerada desde o começo da escravidão. Iemanjá. Nos terreiros dos engenhos... Nas fazendas de café... Os negros dançavam escondido pra suportar os sofrimentos. Os senhores não aceitavam os cultos e as danças das 'Festas dos Pretos', mas eles deram um jeito de continuar homenageando sua Mamãe do Rosário, usando diferentes truques: misturando a língua africana nas cantorias em português podiam fazer críticas e deboches disfarçados contra os algozes de modo a desabafar; mudando a cor e a figura da imagem de negra pra branca de olhos azuis, mascaravam a santa. Ela deixa de ser a Iemanjá dos Pretos para ser N. Sra. do Rosário. Antigamente, na nossa região, a festa era feita nos domínios dos 
grandes fazendeiros". A menina explica do seu jeito que a maior estratégia dos Pretos foi misturar os rituais pagãos com a fé cristã para conquistar a adesão popular. A aceitação, pela sociedade local, era um passo a mais para a celebração quebrar a resistência da Igreja e ser assumida como ritual católico. A mistura das tradições igreja e com as tradições africanas uniu negros e brancos, ricos e pobres debaixo do mesmo teto. "Pra serem aceitos pelo povo, juntaram missa... novena... terço... dança... ritmo... batida de caixa... canto... ternos..." Com o tempo, a festa passou a ser realizada aqui, no centro da cidade, todo ano. "Ninguém sabe a data certa em que os dançadores saíram pela primeira vez batendo os tambores pelas nossas ruas... No começo, só os ternos dos Congos e dos Moçambiques. Depois... outros sendo criados... Catupé, Vilão, Marinheiro, Marujeiro, Penacho e Mariarte... Fundaram a Irmandade de N. Sra. do Rosário. Ela cuida da organização da festa. Escolheu o segundo domingo do mês de outubro para ser o ponto alto".

\section{8}

Sábado, antepenúltimo dia da festa, "Levantação" do Mastro. Luise no largo do rosário explicando para Joãozinho o ritual: "O cortejo saiu da casa do casal Mordomos das Bandeiras com os estandartes de N. Sra. do Rosário e de São Benedito escoltadas pelos Guardas da Coroa e veio caminhando pra cá... batuque...dança... canto... orações... Aqui no largo... Olha lá a roda do povo... O mastro tá sendo levantado... Vamos!" Chegando perto, Luise tapa os ouvidos! "Lá vem o foguetório!". Depois da cerimônia, a missa coroando terços e novenas rezadas a semana inteira.

Domingo pela manhã. Apresentação da congada. Luise e o amigo observam o esforço do Pedrinho dando o seu melhor no Terno do Pio. Joãozinho aponta para o outro lado. “Olha aquele mulato lá! Conhece?” “Aquele é o Marluz!” Luise vê todo mundo capturado pelo desempenho do rapaz. "Parece tomado pela dança!". Não sabia que ele podia dançar desse jeito... Pula... sacode... requebra... agita... Como se a música viesse de muito longe e atravessasse o 
corpo dele inteirinho procurando caminho pra sair na cabeça, nos braços, nas pernas, no tronco... "De vez em quando fala uma coisa ou outra, deu pra perceber?"... Palavras confusas... Não dá pra entender... Olhar fixo, vidrado... Jeito de rezar? Sem olhar pra ninguém...Chama atenção... Parece não perceber tanta gente em volta. Bate com força e com muita graça! Corpo suado. Que jeito de sapatear! Não tem como passar despercebido. As moças não desgrudam os olhos. Elogios cochichados. Suspiros. Olha a cara a da Edwarda! Meeu Deeus... Que olhar mais pidão! Luise vira o rosto... Do outro lado, Pedrinho bem tenta imitar... Vai precisar de muito mocotó!

Depois da missa, o pão... Congos todos para o almoço preparado pelo festeiro e pelas pessoas envolvidas. Fome de quê? Carne de boi, porco, frango. Costume. Luise conta para Joãozinho que a comemoração começara simplesinha com terços e danças nos terreiros. Passara a festejos de congada nas sedes das grandes fazendas, ocasião em que matavam absurdo de porcos, vacas e frangos... enchiam latas de querosene de doces... para o almoço servido pelo fazendeiro e a família aos seus negros, firmando tradição: Na comilança, não podia faltar arroz, tutu, mandioca, almôndega, carne frita guardada em grandes pedaços na gordura, sopa de macarrão com frango...Sede de quê? Banquete regado à boa cachaça. “Pros que gostam”. “Quem não quer?”.

À tardinha, outra apresentação. De novo, as fitas coloridas das roupas dos Congos enlouquecidas... Os tchiques tichiques dos Moçambiques retinindo... Lá vai aquele moço na religião colorida se deixando levar no transe. Autômato. De repente no meio de tanta cor, o branco dos anjinhos surgindo de todo lado... Grandinhos puxados pelas mãos... Menorezinhos, carregados. Olha o padre paramentado abrindo o caminho... Por que tanta pressa? O povo ondula. Acende velas. Aperta. Empurra. Ajeita lugar atrás dele, do jeito que pode... Todo mundo no mexe-mexe... O casal jovem rompendo o caminho... Tem sempre um engraçadinho para dar o esbarrão... "Sem querer". A moça retida pela multidão. O rapaz esperando ela se desvencilhar. A batina parece ganhar vida com os passos largos do padre. Lá vai ele apressado puxando o cordão. Parece quer voltar logo para a paz da sua igreja... "Deus... Cadê suas próprias atrações?" "Onde foi parar a calma boa de rezar ao pé da cruz?". No alto do andor, rodeada de rosas frescas, a imagem da Senhora do Rosário, olhando piedosamente para os próprios pés. A 
procissão indo e voltando... Canto... Reza... No meio dos fiéis de verdade, uma jacuzada pretensiosa se aturdindo na domingueira.

Segunda-feira. Último dia da festa. Entrega da coroa. Pela manhã Luise vai procurar Pedrinho e perguntar: "Quem sabe explicar direito as crenças e mitos que moram na imaginação do povo?" Ele se presta a apresentar o Moçambique vizinho do lado, descendente direto da tradição. O velhinho, perspicaz e altivo, depois de escutar o pedido de Luise e Joãozinho, feito com o maior respeitoso, não se faz de rogado. Sentado do lado de fora da casinha humilde, porte de nobre, faz gesto largo de aquiescência e convida os jovens a se acomodarem sob a sombra.

Nossa Senhora do Rosário apareceu num rochedo de pedra. Todo mundo queria ver. E iam. Uns via, outros não viam. Aí foi padre, celebrou missa lá no lugar. Vamos trazer a santa! Vamos trazer pra Igreja. E ela acompanhava. E no outro dia lá a santa não tava. E tem que buscar de novo. Daí apareceu um preto velho, Pai João e disse: Ó essa é nossa mãe, é nossa mãe. Ah, vamos visitar nossa mãe. Mas eles disseram: Ó, mas que é isso, que, que já foi padre, já foi banda de música, já foi tudo, mas ela não fica na igreja. Esse crioulo é que vai trazer essa santa? Ele nem vai ver ela! E o pai João entrou na mata, tirou taquara, fez um tchique-tchique, que é aquele que nós batemos, e arrumou os companheiros e foi. E já marchando. Quando ele chegou perto, da gente, do padre, a santa já presente. Ele foi, chegou, ajoelhou, cantou ali na língua dele. Beijou. Cantou: Minha mãe, vamos em casa santa? Ela aí saiu. Ela virou e o terno seguiu. Colocou na Igreja e tá lá até hoje, e ficou sendo o Pai João, o maior. Ele conseguiu. Agora, eles falam que é festa de preto. Não, ela não é festa de preto. É festa de todo mundo, daqueles que tem fé. 
Aproveitando a oportunidade de retransmitir oralmente o ensinamento do jeito que aprendeu, o preto-velho parece orgulhoso de poder esticar a missão adiante, falando do tranca-rua:

Se o terno precisa passar numa encruziada tem que passá de costas, por causa do 'tranca-rua'. Senão, a entidade derruba o grupo ou deixa os agouros atrapaiarem a apresentação. Os que tentaram passar com o corpo virado pra frente, caíram. Até quem carrega os andores com as imagens vira de costa pra atravessar. Só a escolta da coroa e a Família Real passa de frente. Não deve dá as costas pra joia. Nas caminhadas pela cidade, quando dois ternos esbarram, um deve pedir licença pro outro pra passar. Pedir cantando. Senão a entidade que protege um terno joga pedra ou marimbondo no outro.

O Moçambique é olhado com respeito pelos jovens e animado pela atenção que desperta, ajuntando algumas histórias:

Teve uma vez que a festa tava chegando e num domingo de manhã, o povo acordou com um susto. No meio da noite... pancada de chuva... baruião danado... a igrejinha desmontada! Raio? A notícia divulgada. O povo chegava pra ver os estragos: "Milagre!”. "Ó a santa lá em cima do portal, inteirinha no seu altar de gesso!" Entenderam logo. "A santa manda recado." "A festa de Catalão num deve acabar nunca." Correram e levantaram a igreja depressa. Teve outra vez que roubaram a coroa. Os féis se uniram em oração e pediram pra santa mostrar onde tava. Foi achada com uma muié. A joia significa o reinado do príncipe e a libertação dos escravos. A Coroa, a imagem de N. Sra do Rosário e a Igreja formam os três elos da Congada.

Começo da tarde, de novo para a Igreja. Outra missa campal. Depois, a comissão da festa e o casal de festeiros velhos escoltados pelos guardiões da coroa, seus responsáveis simbólicos, saem da Capela do Rosário e atravessam as principais ruas da cidade para entregar a jóia ao casal de festeiros novos, 
esperando em local determinado. A entrada do reinado: rei, rainha, príncipes e princesas é anunciada pela cadência dos pés dos Moçambiques, compasso bem medido. A imagem da Senhora do Rosário num andor tão bonito quanto o da procissão da noite anterior ou mais. Faícas! A festeira do ano chega com a coroa protegida pela guarda e passa jóia para as mãos do festeiro novo com a obrigação de organizar da festa do próximo ano. Joãozinho comenta: "Deve ter competição." Saudável. "A festa parece mais bonita a cada ano". Apresentação final da congada...... cantos... danças... acrobacias... Esmero no encerramento. Palmas merecidas. Acaba a festa.

Luise gostou de conhecer o rapaz de Goiânia. Trouxe tanta novidade. Estava sempre com ele durante a festa. O rapazinho se despede. Acabou-se o que era doce. A menina fica com a cabeça dando voltas. Pensa na madrinha Maria, morando de novo em Goiânia. "Pode ir quando quiser. Morar. Estudar.” Quando vem a Catalão, insiste sempre.

Luise enfadada nos seus últimos dias de férias. "Posso usar o telefone, Sr. Custódio?" Quer ligar para o trabalho. Saber como andam as coisas por lá. "Claro, Luise. Posso recusar isso pra minha telefonista favorita?" Escolhe um horário de fluxo pequeno. Torce para Edwarda não atender. "Qual o número, por favor?" Reconhece a voz da Matilde. A colega mora no Bairro S. João, vizinha de Marluz. Ela e Luise já tinham comentado a fixação da Edwarda por ele. A conversa ao telefone acaba resvalando para o assunto. "Sabe... Matilde, eu já não aguento mais ter que trabalhar o tempo todo ouvindo a lenga-lenga da Edwarda sobre esse rapaz". Matilde calada. A menina sabe que a Edwarda está trabalhando na mesa ao lado. Corre o risco. Luise solta o verbo no desabafo. "Se visse a cara dela na festa, não ia acreditar...”

A menina volta a trabalhar no dia em que a cidade é varrida pela notícia da morte prematura. Cochichada. "Suicidou!" "O quê?" "Por quê?" "Bonita." "Que desperdício!" "Uma tragédia!" "Uma moça tão linda." "Cheia de vida." 
"Coitadinha!" Choque em saber que uma moça "bela, nova e esbanjando saúde" morrera antes do tempo. Ninguém perguntava o que estava por trás. Poucos comentários a respeito do motivo. Zunzum discreto. "Os dois combinaram." "Ela cumpriu." "Não tinha saída." "É isso que dá se envolver com homem na situação dele." "Diz que a mulher é doente." "Só podia terminar assim." Pouco importa se o gesto final é da moça ou não. Mais importante do que a vida, a honra lavada. O orgulho. Questão comum. Coisa bem aceita. A pessoa não é pessoa, é família. O destino é apossado. A ovelha negra excluída é o que importa. Bocas caladas. Escândalo abafado. Fim da pouca vergonha. Honra dos parentes resguarda. Suicídio? Não? Não faz diferença. A verdade é sepultada com o corpo jovem.

De noite, na cama, Luise chora. Mergulha a cabeça no travesseiro e chora. Por que acontecem tantas coisas ruins na vida? Será que a felicidade não existe em lugar nenhum? Moça bela. Pele brilhante. Pétala de rosa. Destino breve da flor. Vida. Nasce para cumprir seu papel. Sedução. Diversão. Quebra da monotonia. A flor encanta a todos... Cheiro... Beleza. Acontece qualquer coisa diferente, no tempo dela. Contamina. Desarma. Abre sorriso. Uma rosa bela significa amor. $\mathrm{O}$ amor trouxe o cheiro da morte para a moça linda.

Naquele dia, Luise ligou para a central telefônica e Matilde não deu qualquer sinal de que não era a única a escutá-la. A Edwarda não costuma fazer isso... Será que a Matilde fez sinal pra ela ouvir? A Matilde podia ter dado a entender que tinha 'boi na linha'... Por que não fez? Ai-ai... nesse mundo tem gente pra tudo. Só quando voltou de férias, soube. A Edwarda estava com a pega da mesa dela conectado no circuito corresponde ao da mesa da Matilde e ouvira tudo que a menina dissera a respeito dela. Não pude evitar. Na primeira chance que teve, lá foi a Edwarda reclamar com o superior. Chorosa. Na base do "ela ou eu". Não abriu mão. Luise não foi poupada. A falta não era tão grave. A pena foi desproporcional. Primeiro, a suspensão. Depois, a dispensa. Edwarda, com a sua insistência, venceu a relutância do gerente. 
Luise escuta o ronco do avião... Será o Presidente? Aprendi muita coisa sobre o JK. Na casa do Sr. Cornélio... Na biblioteca... Até os 16 anos, a vida dele não foi muito diferente da minha. Muitas coincidências. Pai e mãe: casais J-J. João-Julia perdeu seu primeiro bebê, Eufrosina, com poucos meses de vida, como aconteceu com Joana-João. O pai do Juscelino era caixeiro-viajante, vendedor, que nem o meu. Pegou um resfriado fazendo serenata na cidade de Rio Vermelho... Virou pneumonia... Cresceu pra tuberculose... Largou a família. Foi morar separado pra evitar pegar o mal nos outros. Morreu e deixou os filhos pequenos: Juscelino com três anos e a irmãzinha com dois, ele chamado de Nonô, ela de Naná. Eu não tive apelidos, mas na escola era às vezes chamada de "olho-de-gato" ou "espoletinha-depapel”. Juscelino quebrou o mindinho do pé brincando de esconde-esconde. Eu tive problema no dedo do pé, quando menininha. Juscelino gosta de dançar, criou fama de pé de valsa, conheceu D. Sarah numa festa e começou a namorar com ela. Eu não levo jeito pra dança, conheci o Auro na escola, e comecei a namorar com ele na festa do Carnaval. Juscelino foi telegrafista, tendo que aumentar a idade de 16 anos pra 18 por causa do concurso. Eu trabalhei como telefonista até agora. Ele queria ser médico e foi para BeloHorizonte estudar. Eu quero voltar a estudar e não sei o que será de mim...

O ruído do avião vai se distanciando... Difícil Juscelino descer aqui... O nosso campo de pouso não é quase usado... Serviu para reunir o povo na missa campal organizada pelos três missionários quando a peregrinação mundial de N. Sra. de Fátima terminou no Brasil. Uma festa pra ninguém esquecer mais. Preparada com antecedência. Os padres chegaram bem antes. Nunca vi fervor igual. O mulherio confessava, comungava, pedia conselho, oferecia ajuda... Animação Atividade. Solicitude. Todas as vezes que eu entrava na igreja, olhares piedosos por todo lado, prontidão em participar. Na despedida, depois da missa no aeroporto... Que beleza! O povo cantando em coro... 
A treze de Maio

$\mathrm{Na}$ cova da Iria

No céu aparece

A Virgem Maria.

Avê, avê, avê Maria

Avê, avê, avê Maria

A três pastorinhos,

Cercada de luz,

Visita Maria

A mãe de Jesus.

$\mathbf{E}$ aconteceu aquela coisa engraçada... Nenês nascendo em quantidade. Batizados com os nomes dos pastorinhos e dos padres, em homenagem. Parecia que a mulherada combinada escolheu a mesma época pra esperar. Vendo aquilo, muita gente juntava as mãos e dizia... "Milagre".

Com a morte da avó, Luise perdeu a grande companheira. A mãe sempre às voltas com seus nenês... Ganhou mais um. Não é louro como o Élcio. Nem moreno como o Ruiz. Quando ri, fecha um olhinho mais do que outro... Dilson é mesmo uma gracinha!

As amigas estão dispersando... A Ivone vive agora viajando pra casa da irmã dela em Ipameri. Está interessada num rapaz de lá. A Lélia desistiu de vez do Zé Torres. Não quis saber do Marluz. Recebeu permissão dos irmãos pra namorar sério, outro Zé. Veio de Minas. Parece bom sujeito. Deve ser ótimo mecânico. Chegou e começou a trabalhar na oficina mecânica da rua. Não é bonito. Nem tão feio pra merecer o apelido de "Zé-doença" que as más línguas botaram nele. O Gercílio bem mais feio namora a Lídia, tão bonita. Anda sumido. Não tá mais na rádio. Deve ter ido pra Goiânia. Não tem muito tempo, fiquei sabendo que a família do Auro foi morar lá. O Sr. Paulo, vejo sempre. Separação de casal não é coisa que acontece todo dia, por aqui. A D. 
Judith foi sempre muito reservada. Foi embora com os filhos, caladinha, pra evitar falação. Será que verei o Auro de novo algum dia?

Luise sobe a Rua Cristalina. Dobra a esquerda. Passa pelas mangueiras. Desce para a Avenida Goiânia. Caminha até o jardim. Meio da tarde. Pouco movimento. Senta no banco favorito, o mais perto do Cine Real, debaixo da velha árvore. Quantas vezes eu já sentei aqui? Muitas-muitas... rindo... chorando... Com os olhos absorvendo o rosa da buganvília, não se dá conta que tora um galhinho de cipreste, esmaga entre os dedos e leva ao nariz. Levanta. Cruza a praça. Sempre bem cuidada. Atravessa a avenida. Vai até a ponte. Para no meio dela. Caminhasse mais um pouquinho, dobrasse a esquerda, daria com a escadaria do São Bernardino e veria o pé de amora... Você gosta de amora? Vou contar pro seu pai que você namora... Quantas vezes, ouvi ou falei isso? Muitasmuitas... O Morrinho de São João oscila à distância. A menina passa as costas das mãos pelos olhos e evita o transbordamento. Volta para a avenida. Passa pela telefônica... Pela confeitaria... Pela casa dos poetas... Sobe a rua da esquina e desemboca no largo da Matriz. A velha boa amiga, sempre lá, de portas abertas, acolhendo todos os que queiram entrar. No interior... Rendas... Rosas... Cheirinho especial... Incenso. Senta. Espia ao redor... Um encanto, o vitral... O silêncio favorece a reflexão. Dá espaço para a lembrança se apropriar do momento. Trazer pedaços de outra tarde. A menina tenta recompor, sorrindo sem perceber... Como foi mesmo? Entrara na igreja naquela vez com várias coleguinhas. Não tinha ninguém. Por que não aproveitar e subir a escada para ver o que tinha no alto do campanário? Galgaram o primeiro lance. Dele não passaram... Credo! No topo mal iluminado, um corpo no caixão. Assombraram. Atabalhoaram. Tropeçaram. Era imagem do Senhor Morto. Souberam, depois. Será que os padres fazem de propósito? Colocam o caixão lá em cima, bem à vista, pra espantar bisbilhoteiros? Luise tenta rezar. Quem disse que consegue? Corre os olhos ao redor. Contemplativa. Na pia batismal, ganhara o nome de Maria. Na mesa da 
comunhão recebera o Corpo de Cristo, pela primeira vez. Vestida de branco. Segurando a vela grande decorada. No confessionário, dissera pecaditos morrendo de vergonha de ser reconhecida pelo padre, através dos buraquinhos. Diante do altar, ajoelhara para comungar muitas vezes. Postara diante do Senhor Morto e fizera vigília, como guarda de honra, na quaresma. Ouvira cantos de Madalenas, nos atos da Paixão... Vira anjos vestidos de cetim e asas de penas, nas festas de coroação de Nossa Senhora... Sonhara um dia entrar vestida outra vez de branco, esperada por ele no altar...

Nesse momento, surge a velha na porta lateral e tira Luise de suas recordações. Observando ela entrar, fazer genuflexão, ajoelhar no primeiro banco, fazer o sinal da cruz e concentrar-se em oração, a menina tapa a boca com a mão e ri. Não dela. Mas da outra, que aflorou na sua lembrança, do jeito que o povo conta. Mês de maio, a igreja lotada pelas 'Filhas de Maria', fita azul celeste e medalha de N.Sra. no pescoço. O padre celebra a missa matinal. A pombinha surge. Esvoaça de um lado para o outro. Dá rasante em volta da careca do padre. Ele tenta espantar. Não consegue. A ave atrapalha o ritual. O sacerdote interrompe o serviço. Contrariado e esbravejando. "Quem ter pomba, ir embora." A maioria das moças de cabeça baixa rezando, compenetradas, não viram a ave, erguem os olhos e não entendem nada, achando muito esquisito o padre dizer uma coisa daquelas olhando para elas! Troca geral de olhares. Todas levantam e saem envergonhadas. Na igreja, só a velhinha, sentada na frente, rezando fervorosamente. $O$ sacerdote atônito se dirige- a ela mais brabo do que nunca. "A senhora não ter pomba?" A velha nem se abalou. "Iiiihhh...meu fio, a minha...'Ooohhh'..." Trisca o polegar no dedo médio rápida e seguidamente e acaba de responder... “...já virou morcego há muito tempo”. Ai, meu Deus! Então igreja é lá lugar para lembrar piada? Ai-ai... Não adianta, hoje não vou conseguir rezar. Desiste. Percebe que falhou no intento de deixar o templo sem atrapalhar a concentração da fiel, vendo a velha torcer o corpo para trás e endereçar a ela riso desdentado. Saiu e foi embora para casa, intrigada. 
Luise não consegue dormir. Pensa na velha da igreja, sem entender a razão do sorriso dela. Pensa no Auro. Sim, tinha visto o Menino, outra vez. Ainda trabalhava na CTC... Saí à porta, na hora do intervalo e dei de cara com ele vindo pela mesma calçada, a poucos metros de distância. Como sempre acontecia quando via o menino, primeiro o choque e depois a confusão... Pernas tremendo... Mãos gelando... Cara ardendo... Ainda que quisesse não conseguiria sair do lugar. Tentou se controlar. Ele chegou perto. Parou.

— Luise... Como vai essa senhorita?

- Bem e você?

Respondeu que estava ótimo, examinando a roupa de trabalho dela.

— Então, trabalha aqui agora.

— Pois é... Como vai a Dona Judith... a Lídia?

Ao invés de responder, surpreendeu com um convite - Passa lá em casa, pra ver as duas e saber.

Com a voz um pouco mais firme, ela perguntou.

— Ué... Não pode me dizer agora?

- Não. Passa lá.

Estava perturbada. Parecia que ia derreter. Ele percebia. Sorriso matreiro. Olhar envolvente. Dominava o jogo. Era impiedoso. "Vou te falar uma coisa." Chegou pertinho. Esticou o pescoço. Soprou no ouvido dela. "Agora, eu já sei namorar, de verdade." O hálito quente... O cheiro inconfundível... E aquela coisa esquisita acontecendo com ela... Como se um rastilho percorresse o corpo da cabeça aos pés... Um arrepio quente parecia poder queimar o uniforme. Uai... Que isso... Credo! Olhou de um lado para o outro, preocupada. Ninguém percebeu. 
Sorte. Dá pra imaginar ficar sem roupa em plena Avenida Goiânia... Como em certos pesadelos... Já pensou?

Aureo falou aquilo e se despediu e foi embora. Luise ficou lá na calçada paralisada vendo a figura dele indo embora. Atravessou o jardim com passos firmes e elásticos. Enquanto se recompunha, a menina falou de si para si, bem baixinho... "Eta goianinho custoso!" Entrou na CTC, completamente perturbada... Nem sei como consegui cumprir o resto daquele turno... $E$ essa agora de 'Vai lá em casa...' $O$ que pode significar?

Naquela noite, dormira mal. Na cama, rolando de lado para o outro, parecia ter febre. Será que eu vou ficar doente? Pensava na afirmação enigmática... O que quis dizer com 'Agora, eu já sei namorar, de verdade'? Pensava no acontecimento, atormentada pelo ciúme e assaltada pela dúvida... Será que ele "aprendeu a namorar" com a lambisgóia loura? Com ela ou com outra... Que importa. Não vou poder conferir. Ainda que quisesse. Muito. Gostar de alguém e sofrer desse jeito... Que inferno! Mas quantas meninas podem dizer que tiveram um primeiro amor tão verdadeiro e bonito? Amor e verdade juntos.

Nessa noite, Luise não dormiu direito outra vez. Com as horas esticadas, pensei bem no que quero. Levanta cedo. Sente-se recompensada pela manhã luminosa. Quer ir ao campo. Não convém ir, sozinha. Acorda Pitida. As irmãs engolem café preto e mastigam pedaços do bolo de fubá, assado pela mãe, na véspera, na panela de ferro com a tampa coberta de brasas. Deixam a casa, sob o intenso sol matinal, caminhando na direção das Três Cruzes.

- A gente vai subir o morro, Luise?

- Não, rodear.

— Lá em cima não tem nada mesmo, né?

- É... Fruta, nenhuma... Só as cruzes. 
— Diz que tem gente enterrada lá...

Luise responde passando por debaixo do arame farpado - Diz que, antigamente, tinha un leprosário...

— O que é um "leporsário?"

- Leporsário não, leprosário, é um lugar onde atendem leprosos para tratamento.

- Hospital?

- Mais ou menos... Lembra uma vez que a gente foi catar gabiroba e viu cabaninhas de pano no meio do cerrado? Parece que aqui...era mais uma colônia de doentes recolhidos e cuidados pelos protestantes dirigidos por uma mulher chamada Helena Bernardes.

- Da igreja da vovó?

- Ah, isso eu não sei. Ouvi dizer que ela se mudou daqui depois que a cidade cresceu, e o lugar não era mais tão isolado.

- Foram eles que colocaram essas três cruzes grandes e pesadas desse jeito?

Luise conta para a irmã o que ouvira da mãe: "São de aroeira e foram colocadas aqui depois que três Joãos se uniram pra construir a primeira igreja no morrinho da Saudade. Diz que outro João danado da vida por não ter sido convidado para tomar parte na construção da igrejinha de S. João, mandou fazer essas três cruzes de madeira de lei para colocar no morro contrário, que ganhou o nome de Morro das Três Cruzes. Foram colocadas no lugar das pequenas cruzes que os pobres fincavam aqui quando enterravam anjinhos aqui no morro. Diz que em épocas antigas, quando havia atraso na queda d'água, era comum subir uma procissão trazendo água para aguar e flores e enfeitar as cruzes ".

A menina lembrou da história, contada pelo professor João Martins, do sargento do Tiro de Guerra, tremendo atirador, que quis simular a tomada do Monte Castelo, ocupando o Morro das Três Cruzes. Saiu com a tropa de madrugada. Dividida em dois grupos: um grupo subiu, o outro ficou como observador. Quando o tempo passou e o sinal combinado não veio, o sargento subiu com o grupo observador. Lá em cima encontrou os seus soldados parados, quatro meninos de branco iluminados e o corpo de um expedicionário da FEB. O herói de guerra, Adhemar Ferrugem, tinha morrido. 
Eu queria ser o irmão caçula do vento,

Para balançar as águas do lago,

Derrubar as flores silvestres,

Brincar na poeira da estrada... ${ }^{15}$

As meninas ganham o campo aberto. Caminham. Pitida cantarolando. Luise calada. Suas objetivas, cor de folha seca, registrando tudo. Depois de algum tempo aponta para uma das árvores amadas e convida a irmã para subir. Sobem. "Pronto!" A passarinhada não se perturba com as novas presenças e continua cantando. O momento é de ajustamento. Ali, as meninas não se diferenciam dos outros elementos da natureza... Flor... Fruta... Bicho... Ficam em cima da árvore de tronco grosso e casca rugosa, por bastante tempo. O sol filtrado entre folhas começa a ficar cada vez mais fraquinho. Os pássaros voam baixo. As nuvenscarneirinhos se arrumam, cobrindo céu com o cobertor grosso e cinza. Começa o espetáculo. A chuva bate forte. As folhas tremem. O som grita. Harmonioso. Luise no alto do galho, pensa ora no coral na matriz, ora na banda que toca no coreto do jardim. Os pingos lavam o sal no rosto dela. O aguaceiro quebra a tensão. Traz serenidade. Também para o pequeno coração. Quando Luise desce e sai caminhando com a irmã, a chuva ainda insiste em cair fininha, mesmo com o sol voltando a brilhar. A luz decomposta em colorido e diáfano cortinado cobrindo todo o cerrado. "Decerto têm raposas se casando, por ai". As meninas passam dialogando debaixo da cerca de arame farpado, deixam o campo na altura do Córrego do Almoço e seguem ensopadas pela rodovia. Passando em frente à casa do seleiro-soldador, Luise aponta... "Lá, o Sr. Gercino batendo sola". Diante da casa dos pretos papudos... "Diz que a D. Augusta tá de cama... Doença ruim. Coitada. É boa amiga da mãe.” Passam pela Cruz do Antero, se benzem e seguem adiante. Dali a pouquinho, Luise para e aponta "Olha as moças-velhas...". As flores multicoloridas crescem livres no canteiro da esquina. Alcançam a Rua da Grota. Tudo parece igual. De olhos bem fechados, a menina corre com os irmãos

\footnotetext{
${ }^{15}$ Estrofe do poema "O irmão caçula do vento" de Catalão Poesias, Lendas e Histórias, do Cornélio Ramos.
} 
e os amigos por ali... Escuta as vozes... As cantigas de roda... Persegue os vagalumes... Conta estrelas.

Mas, as coisas tinham mudado. Diz que a Helena parou de estudar e casou com o primeiro que apareceu... "Um jogador de futebol.” A Marizé tá de namoro firme. A Cecília é talvez uma bailarina. Olhando a casa onde moraram por tantos anos... "Essa é a casa onde o Ruiz nasceu." Pintura descascada. Maltratada. Triste! "Sodade' dele, desde que foi ser padre, a gente não vê." O pequeno Ruiz tinha deixado a família para conviver com estranhos. Fazia tempo. Estudando em colégio religioso, coroinha ajudando em missas e gostando de pensar, encontrou nos padres a referência para ter vida melhor. Promessas falsas? Verdadeiras? Ele iria descobrir sozinho. Lembro o dia em que saiu de casa. Calças curtas. Carinha de menino. Seriedade de adulto. Lembranças. Aperto no peito.

-Tá na hora de voltar pra casa.

Encurtam caminho pela linha do trem. Equilibram nos trilhos. O sol brilha forte, outra vez. O ingazeiro derrama generosa sombra sobre o capinzal verde e as plantas miúdas. Luise grita:

— Obrigada pé de ingá pelas frutas doces e carnudas que tantas vezes comi!

Pitida aponta para o outro lado e pergunta:

— E para o pé de jenipapo, não vai falar nada?

Do lado esquerdo lá embaixo e ao longe, a copa do grande jenipapeiro tremula e parece acenar. "Diz que dá bom licor." Não gosto da fruta. Cheiro é forte e enjoativo. Mas como não gostar da árvore? Linda ramagem. Tronco forte. Conhecia desde pequena. No dia reservado para as despedidas, bem merecia um aceno. "Tchau." Luise abre os braços e inspira com força. Como se pudesse armazenar o ar é puro e perfumado. Sim, Luise está indo embora. Vai partir amanhã. Não sabe quando vai voltar. Eu posso estudar lá, se quiser. A madrinha sempre falou. As promessas vão ser cumpridas? O que vai encontrar? Não sabe ao certo. Não quer viajar sem antes se despedir das coisas que mais gosta. Lembra a falta que sentiu de tudo, quando esteve com Vó Mina na capital. Sabe que não irá só. Não! Nunca estará sozinha. Nem daquela vez, ficou. Ela 
deixa para trás uma parte de si e leva um pouquinho de tudo... Vozes... Sorrisos... Músicas... Esperanças... Amarguras... Alegrias... Cores... Cheiros... Gostos... Pedacinhos do cerrado, agasalhados no coração da menina,

$\mathcal{P A R \mathcal { A }} S \mathcal{E} \mathcal{M} \mathcal{P} \mathcal{R}$

Aonde ela for 


\section{2 \\ Referências Bibliográficas}

A PONTE. JK e Lula, pontes Históricas. Disponível em: <a-ponteaponte.blogspot.com.br/2007/01/JK-e-lula-pontes-historicas.html> Acesso em: 24 fev. 2013.

ANDRADE, M. Poesias Completas. São Paulo: Martins Editora, 1666.

BATAILlE, G. A Linguagem das Flores. Paris: Documents.

BENJAMIN, W. "Infância em Berlim por volta de 1900". Rua de mão única. Trad. Rubens Rodrigues Torres Filho e José Carlos Martins Barbosa. São Paulo: Brasiliense, 1987.

CAMPOS, M. das D. Catalão Estudo Histórico e Geográfico. Goiânia: Bandeirante, 1977.

CORALINA, C. Poemas dos Becos de Goiás E Estórias Mais. 19.ed. São Paulo: Global, 1997.

COUTO, R. C. Juscelino Kubitschek. Biblioteca Digital da Câmara dos Deputados, 2011. Disponível em : <http://bd.camara.gov.br> Acesso em: 18 abr. 2012.

Por que JK construiu Brasília? Disponível em: <Veja.abril.com.br/especiais/Brasília/por-que-jk-construiu-brasilia-p-42.htlm> Acesso em: 01 mar. 2013.

GÓRKI, M. Infância. Trad. Rubens Figueiredo. São Paulo: Abril, 2010.

JORNAL DO BRASIL . A2, 8 de maio de 2003. Disponível em: <memóriajb.com.br> Acesso em: 18 abr. 2012.

MARQUES, G. G. Crônica de uma morte anunciada. Trad. Remy Gorga, filho. Rio de Janeiro: Record, 1981.

MENDES, M. A idade do serrote. São Paulo: Record, 2003.

MONTERO, R. A Louca da Casa. Trad. P. Wacht e A. Roitman. Rio de janeiro: Ediouro, 2004. 
NAVA, P. Baú de Ossos. São Paulo: Companhia das Letras, 2012.

NIETZSCHE, F. W. Assim Falou Zaratrusta. Trad. Mário da Silva. Civilização Brasileira. 4. ed. Rio de Janeiro: 1993.

MORLEY, H. Minha Vida de Menina. 11. ed. Rio de Janeiro: José Olympio, 1971.

O GLOBO. Traços de uma poeta. Segundo caderno, 26 de outubro de 2011.

POLONIAL, J. T. Anhanguera: História de Goiás. Goiânia: Kelps, 1997.

PROUST, M. No Caminho de Swann. Trad. Fernando PY. São Paulo: Abril, 2010.

QUEIRÓS, B. C. Por parte de Pai. Rio de Janeiro. RHJ, 1995.

RAMOS, C. Colina dos Poetas. Goiânia: Kelps, 1992.

Catalão de ontem e de hoje. Catalão: Distribuidora Kalil,1984.

. Catalão, poesias, lendas e histórias. Catalão: Gráfica e Editora Modelo, 1997.

RAMOS, G. Infância. 18. ed. Rio de Janeiro: Record, 1982.

ROSA, J. G. Grande Sertão: Veredas. 19.ed. Rio de Janeiro: Nova Fronteira, 2001.

Magma. Rio de Janeiro: Nova Fronteira, 1997.

O Recado do Morro. Rio de Janeiro: Nova Fronteira, 2007.

SAINT-HILAIRE, A. Viagem à Província de Goiás. Trad. Regina Regis Junqueira. Belo Horizonte: Itatiaia, 1975.

SCHWARZ, R. Duas meninas. São Paulo: Companhia Das Letras, 2006.

SOUZA, C. de ; CARNEIRO, M. E. F. Reprospectiva Histórica de Goiás: da colônia a atualidade. Goiânia: Livraria Cultura Goiana, 1996.

TEIXEIRA, J. M. De modo que... Catalão: Gráfica e Editora Modelo, 2003. 
VASCONCELOS, J. M. Meu pé de Laranja Lima. 9.ed. São Paulo: Melhoramentos, 1968.

VAZ, C. Vultos Catalanos. Goiânia: Kelps, 2009.

VEIGA, J. J. Os cavalinhos de Platiplanto. Rio de Janeiro: Civilização Brasileira, 1972.

VERÍSSIMO, E. Clarissa. 51.ed. São Paulo: Globo, 1997.

UFMG. A Cartografia do Distrito Federal. Graciete Guerra da Costa. Disponível em: <https://www.ufmg.br/rededemuseus/crch/costa_medeiros_acartografia-do-didrito-federal.pdf> Acesso em: 24 mai. 2012.

WIKIPEDIA. Origem e educação. Disponível em: <PT.Wikipedia.org/Wiki/Juscelino Kubistchek> Acesso em: 24 de fev. 2013. 


\section{3 \\ Autocrítica}

$\mathrm{O}$ jovem sorri na tela enquanto ela dura. O sangue lateja sob a pele deste rosto de mulher, e o vento agita um ramo, um grupo de homens se apressa em partir. Num romance ou num filme, o jovem deixa de sorrir, mas começará outra vez se voltarmos a tal página ou a tal momento. A arte conserva, e é a única coisa no mundo que conserva.

Gilles Deleuze

Parece que há coisas que acontecem antes das ideias, das palavras... Aproximam-se de algo como um sentimento, um incômodo, não sei... Um livro pode ser escrito só pelo desejo?

Antonin Artaud, movido pelo desejo de ver circular sua obra considerada “impublicável”, surpreendeu o editor e atingiu seu propósito pela força da coerência que alcançou ao defendê-la. ${ }^{16}$

"Somos feitos da mesma matéria de nossos sonhos.", , Shakespeare intuiu. Existem coisas para além das nossas certezas.

A ideia inicial do meu trabalho partiu do sonho de preservar uma fatia do passado pré-televisivo, pouco apreendido por outras linguagens como a fotografia e o cinema, arquitetando uma história a partir de impressões próprias, captadas na infância transcorrida numa cidadezinha do interior de Goiás.

Adulta e radicada em contexto metropolitano, acompanhando o desenvolvimento do progresso que arrasta irremediavelmente as particularidades dos contextos em direção a uma homogeneização radical, comecei a sentir o peso da responsabilidade de guardiã do passado, exigindo o compartilhamento do fardo nobre no presente. Como se as perdas e privações que abalaram a minha infância tivessem ocorrido, talvez, para fortalecer o imaginário, refinar a sensibilidade, aumentar a capacidade de observação, fixar a independência de pensamento,

\footnotetext{
${ }^{16}$ Carta a Jacques Rivière, 5 de junho de 1923 - Obras Completas, Paris: Gallimard.

17 "We are such stuff / As dreams are made on" - The tempest, Act IV, sc. 1
} 
direcionar o olhar para uma janela particular de modo que, mesmo no lugar mais feio e sujo - "Tem uma florinha, ali." - pudesse ver o belo; adestrar a virar o rosto para o lado contrário da dor, sublimá-la na poesia, não me deixar tragar pelos dogmas eclesiásticos e provincianos que dominavam a cidade; crescer determinada a resguardar um tesouro que me foi confiado para dele só me desvencilhar no livro que sou compelida a escrever, tomar a obrigação e dar a ela alta prioridade.

Ciente de que uma vida, por mais atribulada que seja, quase nunca, por si só, pode despertar maior interesse, aspirei fazer da protagonista fio condutor para trazer à tona a experiência de determinada comunidade em certa região abraçada pelo campo, cuja população é regida pelas mesmas regras de comportamento, irmanada pela mesma herança cultural, econômica e histórica.

A par de que o deslocamento de percepção da temática abordada não reproduz o mundo real, mas transfigura-o pelo olhar distanciado e faz surgir objeto novo, agarrei-me à possibilidade de me munir de referências do mundo verdadeiro.

Dissertar personagens a partir de modelos originais, misturando elementos racionais com irracionais de modo equilibrado para imbricar o real no ficcional, na urdidura imaginária de um texto provocativo e inquietante.

Colocar a protagonista em trânsito pela teia de relações para registrar costumes, tradições do corpo social, que seguia ruminando intrigas, desfrutando da convivência aparentemente pacata, enquanto se ocupava, por um lado, em tomar conta uns da vida dos outros e, por outro, em praticar a solidariedade mútua nas trocas e repartições.

Fazer a menina testemunhar o comportamento de um conjunto populacional politicamente dominado pela mão de ferro da hegemonia pecuária e rural, acostumada a tocar a vida no compadrio e a acabar com as pendengas maiores picando à faca ou estraçalhando à bala.

O hábito da leitura me permitia enxergar a linguagem ficcional como um instrumento hábil para trabalhar com coisas existentes, coisas inexistentes e coisas desaparecidas. A ficção é sonho escrito. Entreguei-me ao sonho de escrever o 
livro. Por amor. Amor pela terra onde nasci. Um livro pode ser escrito só por amor?

Desde o início, soube que a empreitada não podia ser encarada de modo leviano. A experiência de leitora escancarava para mim a potência política do fazer literário como não banal. A intuição bradava que um romance não se sustenta numa escrita ingênua.

Perseverei na intenção. "É só escavar o passado, que imagens antigas saltam, alegrias jorram e amarguras derramam". Pensei. Na ilusão de poder voltar para a vida vivida, mal comecei a mobilizar a memória... "Cadê a autonomia?" Os dados iniciais que eu tinha não eram mais do que fiapos de lembranças obscuras, impulsionais e obsessivas. "Imaginação, para onde vai remendando as lembranças esfiapadas desse jeito?" Fato e fantasia fundiam-se. A minha história transformava-se numa constelação de resíduos heterogêneos. Os ingredientes tornavam-se indiscerníveis e não podiam mais ser desunidos do mesmo modo que seria impossível separar farinha de trigo, ovo, manteiga, açúcar ou limão da massa pronta da madalena.

Percebi que a substância artística tem leis próprias, sofre interferências da cultura em que está embebida e que certos problemas precisam ser resolvidos em cima da matéria mesma que o artista trabalha. Seja pintor, escultor ou compositor sabe o quanto lhe custa o desempenho do seu trabalho.

A figura moderna do artista deleuziano é a do "artesão cósmico", a do artista que olha os meios em volta de si, capta "o rastro da criação no criado", instala-se "nos limites da terra" e se interessa pelo microscópico, pelos cristais, pelas moléculas, pelos átomos, pelas partículas, não em função da conformidade científica, mas "pelo movimento imanente."

Apropriando-se da ideia de Nietzsche do eterno retorno "como pequena cantilena, como ritornelo, que captura as forças mudas e impensáveis do Cosmos", Deleuze diz que o artista abre-se ao Cosmo para captar forças numa "obra", que requer "meios muito simples, muito puros, quase infantis..." O ritornelo seria um prisma, um cristal de espaço-tempo agindo sobre tudo que o rodeia - som ou luz - tirando daí vibrações variadas, decomposições, projeções, transformações - e teria função catalítica - aumentar a velocidade das trocas, 
provocar reações naquilo que o rodeia, assegurar interações indiretas entre elementos sem afinidade, formar massas organizadas. Para desencadear o devircósmico, sair dos meios, sair da terra, ser um artesão, ao invés de um artista, é preciso ser um criador, um fundador (Deleuze, 1997, p.160). Entreguei-me ao texto, trabalhando "com os meios em volta"18,

Quase tudo, aproveitado. Mas, Vó Mina gosta mesmo é das verduras. Pega uma coisinha aqui, outra coisinha ali, outra acolá, umas ervilhas, umas ervas, brotos da aboboreira que chama de cambuquira... E olha que comida simplesinha e gostosa!

$\mathrm{Na}$ cena de iniciação da inexperiente protagonista no ofício da costura, a evolução do processo do fazer literário, metaforizada: ${ }^{19}$

-Luise, encontrei a Leontina na rua e ela me disse que está muito apertada de costura. Perguntou se pode ajudar.

—Eu... Como? Não sei costurar, Mãe...

- Bobagem... Já fez tanta roupa de boneca... Bordado pra sua professora... É serviço de mão. A Leontina ensina. Aproveita as férias pra ganhar um dinheirinho.

A inexperiência era comparável à da personagem que fazia roupinhas de boneca e foi sendo iniciada no ofício da costura trabalhando como ajudante da costureira de "mão cheia".

Logo Luise começa a passar algumas horas das tardes, imersa nas cores do arcoíris, aprendendo a distinguir diferentes tecidos... Musseline... Fustão... Piquê... Cambraia... Chiffon... Seda... Georgette... Javanesa... Chamalote... Renda... Organza... Morim... Laise... Gabardine... A reconhecer linhas.

—Você pensa que linha é linha e pronto? Nada disso, minha filha, cada pano pede uma diferente...

- Como saber a certa?

- A linha tem que estar de acordo com o tecido, a costura... É preciso pensar em resistência, suavidade, espessura, cor... Pano mais grosso, linha mais grossa... Linha fraca em tecido grosso arrebenta. Um bom teste é tentar partir a linha com a mão... Cuidado pra não se cortar!

\section{A Leontina entende mesmo do "riscado."}

- Fio fino serve pra pano delicado... Se o tecido é fino e leve, tem que usar linha suave, lisinha...

\footnotetext{
${ }^{18}$ Idem, p. 66

${ }^{19}$ Cf. parte 1, p. 130
} 
- Como saber se a linha é assim?

- Passe o fio no lábio. De novo, cuidado pra não se cortar! Num tecido de trama aberta, a linha tem que ser mais espessa. O risco de ter um fio puxado depois, é menor. Fio grosso também é usado em trabalhos decorativos, bordados...

- E a cor?

- Depende do efeito que busca... Quer combinar com a cor do tecido? Contrastar?

Se o pano é xadrez ou listrado, a dica é optar pela cor mais escura.

- Pensava o contrário.

- Parece que o olho humano repara mais num detalhe claro sobre uma base escura do que o contrário, a cor mais escura disfarça a costura.

No universo diegético, a menina precisa de algum tempo para aprender a ocupação a ela ensinada.

Não demora muito e Luise aprende a lidar com o material usado pela Leontina. Alinhava enfeites: renda, fita, gorgurão, sianinha... Prega botão, colchete, chuleia, faz bainhas... A costureira sempre por perto com a atenção voltada para o serviço dela. "Em fazenda delicada como essa, não poderia usar o ponto 'espinha de peixe' pra fazer a bainha".

Da mesma forma que a personagem, principiei a ganhar prática no meu ofício sob orientação permanente e cuidadosa. Queria escrever um livro não ingênuo, saber lidar com os materiais da criação literária, utilizar o conhecimento e erigir um trabalho artesanal, pensado. Dispus-me a dar atenção não só ao que a lembrança oferecia de pessoal e útil à prática literária, mas a levar a efeito criteriosa pesquisa teórica voltada para investigação da noção da escrita contemporânea, apropriando-me de determinados conceitos da filosofia recente como intercessores para engendrar um romance entremeado de resíduos da memória colados com a fabulação criativa, apresentando percepções artísticas capazes de se aproximarem de conceitos da filosofia contemporânea.

A arte é coisa mental. Uma parte do trabalho dedicada à análise de documentos, exame de textos históricos, periódicos, fotografias, objetos significativos, entrevistas, leitura de longa lista livros sobre infância e filosofia. Outra parte à escritura, propriamente dita. A tarefa suscitou receios e vacilações semelhantes aos da personagem menina chamada pela professora, à mesa dela, com o pedaço de linho e as meadas na mão... "Pode bordar isso pra mim?" 20

\footnotetext{
${ }^{20}$ Cf. parte 1, p.31.
} 
Tive receio de não dar conta. $O$ risco era grande. Dava volta no quadrado inteiro. Parecia pedir até ponto cheio, talvez até rococó e sombra... Já tinha bordado um ou outro paninho de prato... Ponto-atrás... Maria preguiçosa... Correntinha... Só. Mas não podia ir logo dizendo não pra D. Odete, sem pelo menos tentar. Não foi fácil. Passei bons apertos escolhendo as linhas, combinando as cores... No fim, acho que deu certo. Bom demais provar aquele doce gostoso, ganhar o estampado de bolas, bonecas e bichinhos espalhados... Só ficou faltando uma coisa... A D. Odete dizer se o bordado ficou bom ou não. Será que vai dar tempo de fazer o vestido para levar na viagem?

Não esquecia a lição de Deleuze de que o artista se abre ao Cosmo para captar forças numa "obra" e que essa abertura, mais do que devaneio, serve para ampliar os limites da terra, na criação da obra, que requer "meios muitos simples, muitos puros, quase infantis..." 21

$\mathrm{Na}$ vivência do quintal murado, menininha crescia e aprendia a amar a terra. Ainda não podia se expressar com palavras. Nem precisava. Externava respeito na contemplação embevecida daquele mundo encantado... A profusão da folhagem... A alternância das cores... A exuberância da floração... No canteiro multicolorido, o girassol era rei. Flor preferida do Tio. Não podia ainda subir nas árvores. Sentava à sombra delas. Escutava passarinhos, cigarras... Prestava atenção ao som do vento... Observava a vida miúda - tatuzinho-bola, joaninha, centopéia, lagarta, minhoca, caramujo, borboleta branca, azul, preta amarela... Fuxicava a terra. Sujava as mãos. Fazia arte. Algumas manguinhas caídas, poucos gravetos... Pronto. Era rica. Dona de rebanhos de vaquinhas verdes.

Não olvidada também a reafirmação do filósofo sobre a compreensão que Paul Klee tem do assunto, dizendo que exercemos um esforço por impulso para decolar da terra e nos elevamos acima dela, sob o império de forças centrífugas que triunfam sob a gravidade.

O texto autoficcional parte da memória pessoal para a escrita criativa de si e faz desaparecer a dicotomia verdade-ficção. No tocante à semelhança entre essas instâncias, cabe pensar no que Deleuze diz: “é uma semelhança produzida por seus próprios meios: o sorriso na tela é feito de cores, de traços, de sombra e de luz". "O plano do material invade o plano do composto das sensações e passa fazer parte dele" (Deleuze, 2010, p.196).

Compreendi que a prática literária, mesmo quando se quer autobiográfica, é um verdadeiro "faz de conta" e optei pela autoficção para compor a imagem do

\footnotetext{
${ }^{21}$ Cf. parte 1, p.19.
} 
passado, cuja inteireza escapava mas investia intempestivamente no presente com insistentes fragmentos anacrônicos fulgurando na memória, tendo que enfrentar questões que surgiam.

Autoficção: da memória pessoal à escrita-invenção de si. Narrar objetivamente o que vivemos não é uma impossibilidade? Ao lembrar, inventamos? Quem somos senão quem decidimos ser?

$\mathrm{Na}$ obra literária as figuras do imaginário, originalmente, fragmentadas, nebulosas, difusas, solidificam-se de forma objetiva na fabulação, propiciando que o ato da escrita seja integralizado pelo ato da leitura, ponto de entrecruzamento do estado do sonho e o da vigília, em que o leitor movimenta-se alternadamente do real para o imaginário, com cenas do mundo "real" e imagens do texto sendo simultaneamente evocadas, apagadas, fantasmagorizadas. A ficcionalidade da literatura deixa a relação da obra com o mundo aberta à interpretação dos leitores.

No jogo do fingimento o real é percebido e transformado pela criação do imaginário num ponto de ruptura, instituída pela obra de arte, onde a referência se aninha. A mimese ultrapassa a referência, evita repetir o modelo prévio de realidade ou subjetividade e o receptor assimila modos possíveis de ser, autorreferências novas numa "aprendizagem ativa" que une a expansão prazerosa dos afetos à determinação cognitiva.

Convencida da noção bergsoniana de que o tempo é o tempo no seu devir, senti-me encorajada a explorar a prospecção sensorial, a me esforçar para (re)viver ambientes, atmosferas, através do feixe de interações dos múltiplos personagens da cidadezinha de outrora, relembrar o apanhado de costumes e tradições locais na tentativa de provocar experiências mais concretas, robustecer a obra com a lembrança do passado revivida no futuro com a percepção que não captara no tempo anterior.

Aprendi, na leitura de Deleuze-Guattari, que a lembrança, instância da ordem do sensível, que o sujeito não controla, é capaz de trazer outro tempo, na experiência da descoberta, através da arte e do conhecimento, no futuro, de um viver ainda não vivido no passado, para o qual não se estava preparado. A experiência só pode ser reconstruída a posteriori e não no próprio tempo, pela sensibilidade, que capta a essência daquilo que se viveu. A arte da escrita se faz de 
lembranças do cheiro, do gosto, da sensação de pisar no paralelepípedo, etc. Os sentidos do corpo que escreve são responsáveis por forjar, no trabalho com a linguagem, uma vivência infantil, registrada como memória. O corpo que se relaciona com a memória não está no sujeito e não está na lembrança do objeto, é uma sensação. Assim se apresenta como potência criativa que, se for ativada, permite a presentificação de passado e futuro, propiciando, pela leitura, uma vivência desdobrada em duração.

Com Proust e Barthes, percebi que olhar uma fotografia, experimentar um sabor, pisar num paralelepípedo, escutar as notas de uma melodia, sentir aromas, pode ser determinante na caracterização de uma fatia de tempo. Sensações apreendidas em determinada época podem perdurar, em estado de latência, como índices na memória, com possibilidade de abertura e expansão pelos sentidos. Costumo pensar neles como "ícones" minimizados, que uma vez "clicados" e abertos podem ramificar em "links", ressoando ecos da época em que foram experienciados.

A sensibilidade cria uma ponte, estabelece a relação e condensa a experiência de presente e passado. O presente se torna presente no passado e viceversa, numa sensação que não está na memória que o sujeito guarda do objeto, mas no eu em constante devir, presente apenas como possibilidade que se abre pelo contato. "A memória intervém pouco na arte" diz a filosofia deleuzina. "Não se escreve com lembranças da infância, mas por blocos de sensações, que são devires-criança do presente", um material complexo que não se encontra na memória, mas nas palavras e nos sons. Algo como a música. Algo mais que memória (Deleuze, 2010, p.198).

Sendo o elemento pré-textual apenas ponto de partida para a compreensão comum dos leitores, ao operar a memória em ficção artística, possibilita-se o contato da produção com a recepção. Inspirada em Proust quando diz que a imagem é o único elemento essencial no aparelho das nossas emoções e que o achado do romancista foi ter tido a ideia de substituir partes impenetráveis do ser pela mesma quantidade de partes imagéticas que a alma do leitor pode assimilar, quis mobilizar a memória e a inventividade, abrir as comportas e deixar as imagens mentais jorrarem, formando precipitado no suporte material. 
A narrativa das reminiscências foi sendo construída por meio de referências diacrônicas a eventos posteriores e anteriores, a cenas políticas ou a reflexão sobre algum aspecto do período histórico em pauta: uma conversa da avó serve para evidenciar a luta do camponês por um pedaço de terra; a conversa da menina com um amigo remete ao aparecimento da televisão do rock and roll; a ida ao campo e a visão de uma cabana de trapo dá ensejo a reflexão sobre a hanseníase para ser comparada posteriormente com a postura da época em relação à prostituição. Assim, produz-se efeito, usando as lembranças de várias maneiras e meios: cheiros, sons, lugares, personagens, instituições, ritmos de deslocamentos de veículos, trem ônibus, caminhão.

A relevância da concretização da proposta, recortando sincronicamente a linha do tempo e (re)compondo literariamente a vivência de certa comunidade, implica: fazer emergir dados sociais difíceis, senão impossíveis de serem de outro modo recuperados; tentar preservar tradições, usos, costumes, comportamentos, brincadeiras, jogos infantis de um contexto brasileiro que transcorreu isento da interferência da mass media.

Trabalhando com um recorte de tempo específico, pensei em Foucault dizendo que uma época é feita das suas visibilidades e dos seus enunciados, para ensinar aos pesquisadores a investigar não 'o que está por trás' dos textos e documentos, nem 'o que se queria dizer com aquilo', mas, sim, quais as condições de existência de um discurso ou enunciado (Foucault, 1998, p.14-15).

Visibilidade. Enunciado. Palavras que remetem à visão e à audição. Pensei no que é captado pelos demais sentidos, na importância dos cheiros, das sensações e dos sabores para a caracterização de determinada época. Pensei na Teoria do Belo de Baudelaire - o belo formado pelo elemento histórico constante e pelo componente circunstancial variável, refletido na moda, na moral, na paixão. Pensei em Combray saindo inteira de uma xícara de chá de tília, degustado com a madalena.

Outra questão evocou o autor de Sobre a Modernidade: o mal estar causado pelo espinhoso tema da 'globalização' - cuja capilaridade avança irremediavelmente, igualando contextos, nivelando comportamentos, num mundo interligado pelas redes de comunicação, saturado de imagens e dominado pela 
mídia - que me fazia querer preservar o registro de um viver mais singelo. Quando Baudelaire foi privado da proteção do mecenato, desceu do "Olimpo" e perdeu a auréola, tendo que lidar com o incômodo da modernidade, o que fez? Embebedouse dela, processou e regurgitou poesia.

Faceando hipóteses e questões, entreguei-me à experiência estética. Sustentada pela fé de que a experiência de outrora, estetizada no presente podia, talvez, servir para o leitor mirar, cotejar afinidades e disputas entre pessoas, perceber e driblar a dominação grassando, escamoteada.

Tradicionalmente, o romance da adolescência tem sido um desafio para muitos escritores, porque, aí, torna-se impossível aceitar personagens que falem a mesma língua do autor, pensem e ajam como adultos, situando-se irremediavelmente, fora da capacidade de compreensão dos leitores.

No prefácio "Releitura de Clarissa", Flávio Loureiro Chaves diz que o romancista será bom ou mau justamente na medida em que a sua capacidade de expressão nos faça aceitar como verdadeiro esse mundo que é de pura fantasia, quando as pessoas fictícias nos convençam e emocionem tanto quanto as 'reais'.

O problema da narratividade, o primeiro a demandar atenção, se ergueu como o maior desafio para a concretização da proposta: Como fazer para clarificar fatos graves da história complexa sem podar a voz infantil com a inexperiência que equilibra a gravidade do discurso? Decidi experimentar um hibridismo enunciativo pelo qual a narradora adulta fala do passado nos momentos mais cruciais, sendo gradualmente contaminada pelas lembranças, entrando numa espécie de regressão e cedendo espaço para a voz infantil se apoderar do discurso para empurrá-lo adiante, fantasiando.

A substituição de vozes implica alterações no universo diegético: a narradora adulta opta por uma linguagem mais densa, evita ênfase, adjetivação exagerada, usa uma prosa mais seca, deixando a articulação do episódio falar por si mesma, levando o receptor a se sentir mais próximo dos acontecimentos. A personagem infantil, por sua vez, nos momentos de maior sofrimento ou alegria, traz a fantasia, ocupa o ponto de vista enunciativo e a poesia comparece. A narração passa para o discurso direto, o passado pula para o presente e, se o momento diegético permite, a interação evolui diretamente para o diálogo. 
A instância narrativa é um problema de estilo e de poesia. O recurso narrativo híbrido solucionou a questão da coerência do discurso. A personagem adulta e a infantil duplicando constantemente as vozes em cena. $\mathrm{O}$ encaixe das vozes na história narrada é mistura proposital. O discurso mais complexo, por conta da narradora adulta. Certos eventos e ambiguidades pela voz da menina registrando os acontecimentos sem entendê-los perfeitamente. Tentativa de fazer o leitor perceber tudo através de alguém que compreende quase nada, devolver a ele dificuldades do pensamento, mistérios da vida, tremuras da adolescência nos momentos incompreensíveis de sexualidade incipiente da adolescência. A diferença de vozes é bem marcada no texto: voz adulta fala a linguagem formal; voz infantil, a oral. O pensamento da menina é sempre negritado. No trabalho todo, é perceptível a intenção de mostrar os volteios do pensamento tal como rizoma com cada caminho se ligando a outro, sem centro, sem periferia e sem saída. A tessitura do pensamento rizomático é mostrada como uma colcha de retalhos que resulta de simples quadrados e elaborados fuxicos entremeados.

Embora a narratividade se apresentasse, desde o início, como questão crucial a ser explorada e desafiasse a experimentar o recurso narrativo híbrido, outras questões no projeto demandavam atenção. Como preservar uma sensação? “A arte conserva, é a única coisa no mundo que se conserva" (Deleuze, 2010, p.193). A resposta deleuziana surpreende: o projeto aspira rebentar numa obra de arte? Nunca tinha encarado isso de frente. Traz outra pergunta. O que é arte? "Toda obra de arte não é um ato de resistência, e no entanto, de uma certa maneira, ela acaba sendo" (Deleuze, 1999). Pronto! Finalmente, no colo da autora, a motivação nua e crua. Com a conscientização, pode inferir que o plano de escrever o livro se engasta na possibilidade de se posicionar na vida, depreender de onde vem a necessidade visceral do que quer fazer, ver respondidos os antigos e renitentes porquês - Por que persevera na ideia de escrever? Por que não se contenta em fazer tricô? Por que persegue o aperfeiçoamento técnico? Por que escrever o romance era uma necessidade?

Deleuze responde que não temos ideias em geral, que ideia surge destinada a certo domínio, aparece como potencial já empenhado em algum modo de expressão e compreende que ideias aparecem em função de técnicas que se podem 
dominar. Por experiência própria, eu podia confirmar que "ter uma ideia é uma espécie de festa" (Deleuze, 1999).

Alcancei, por fim, a compreensão de que a busca pertinaz pelo aprimoramento na escrita decorre simplesmente de certa intimidade que se tem com o meio de expressão: tivesse facilidade para pintar, procuraria melhorar e compor quadro expressivo; pudesse esculpir, cabia aperfeiçoar-me e erigir bela estátua; pudesse compor, iria aprimorar-me e alcançar perfeita harmonia. Seduzida pela ideia-festa, me deixei levar pelo impulso inventivo, entrei no barco que ganhou mar aberto a mercê do assalto corsário das questões.

Como utilizar a palavra para explicitar gestos, pose, ar e tipo de vida, de maneira convincente? O objetivo da arte com os meios do material é extrair um bloco de sensações, diz Deleuze e ensina que "sempre é preciso o estilo - a sintaxe de um escritor, os modos e ritmos de um músico, os traços e as cores de um pintor" (Deleuze, 2010, p. 201)

O que é ser romancista? "Um grande romancista é, antes de tudo, um artista que inventa afectos não conhecidos ou desconhecidos, e os faz vir à luz do dia como o devir dos seus personagens" O artista é mostrador de afectos, inventor de afectos, criador de afectos em relação com os perfectos, ou a visão que nos dá. Através do artista, os perceptos fazem estourar as percepções vividas numa espécie de cubismo, de simultanismo, que não têm mais outro objeto e nem sujeitos que não eles mesmos. (Deleuze, 2010, p.206), Entre os artistas, o romancista excede os estados perceptivos e as passagens afetivas do vivido. Um monumento não comemora, não celebra o que passou, mas transmite para o futuro as sensações persistentes que encarnam o acontecimento". O escritor trabalha com as palavras, cria "uma sintaxe que as introduz na sensação, e que faz gaguejar a língua corrente, ou tremer, ou gritar, ou mesmo cantar: é o estilo, o 'tom', a linguagem das sensações ou a língua estrangeira na língua, a que solicita um povo por vir. (Deleuze, 2010, p. 208).

Deleuze, fonte das afirmações acima traz o exemplo de Proust, que inventa um afeto ao colocar o ciúme como destinação e inverter a ordem da opinião nas afecções, que tem no ciúme uma consequência infeliz do amor - se é preciso amar, é para poder ser ciumento - Deleuze é enfático. “A arte não tem opinião". Mostra com Proust que os afetos criadores podem se prender em compostos de sensações 
ou se desviar dos mesmos; estes se transformam, vibram, se enlaçam ou se fendem, de um escritor a outro. E são esses seres que, no entendimento deleuziano, dão conta da relação do artista com o público, da relação das obras de um mesmo artista ou de uma eventual afinidade de artistas entre si (Deleuze, 2010, p.207).

A arte produz pensamento? Não há como duvidar. A arte não pode ser alijada da construção do saber. Com os grandes autores, aprendi quase tudo que sei. Os romances que li me levaram a pensar. A arte literária me trouxe até aqui. A ficção é uma forma peculiar, mas potente de conhecimento. Não o conhecimento das respostas retas, mas aquele que se manifesta de través. Surpreende com perguntas de esguelha. Esburaca o senso comum. Leva a tremer. De sobressalto. Ou deleite. Não o conhecimento do conceito e da abstração. Mas o da fantasia e da vida. Só a arte expõe com ironia, compaixão e maravilhamento a nossa fragilidade, a nossa patetice, fazendo da nossa impotência uma potência.

Lidar com a arte é trabalhar na fronteira tênue, que mal e mal nos separa de outros elementos da natureza e nos diz que a vida é muito maior do que as verdades humanas estabelecidas. Toda gama de sentimentos cabe na arte. Beckett afirma que "a arte deve abarcar o caos". Sylvia Plath, que "a arte é roubo, a arte é assalto à mão armada, a arte não é agradar a sua mamãe.”

A linguagem literária constrói o próprio universo. Não "representa" o mundo, mas "apresenta" o que Blanchot chama de "o outro de todos os mundos." Não se refere a um objeto ausente, mas evoca o objeto em seu esplendor. As palavras colocam o leitor em contato com a irrealidade da obra ficcional. Apresentam situações e sensações que reverberam no corpo do leitor, sentidas e vividas, numa experiência real, na realidade plena do mundo imaginário (Levy: 2003). Constroem personagens, inventam trajes, jeitos de ser, criam os cenários para sua vida acontecer, seus gestos, seu olhar, seu sorriso, sua dor, sua alegria, sua pequenez e grandeza, seu ridículo, dão vida a personagens com os quais nos identificamos intensamente.

Decidi não apenas contar sobre o passado, mas contar no passado e levar o leitor até mundo construído para a história. Um mundo edificado com palavras. O narrador preso pelas próprias premissas e o desenvolvimento da narrativa 
situando-o no mundo construído. A história fazia parte do mundo diegético e precisei lançar mão dos recursos informativos disponíveis para o espaço-tempo abrangido.

A linguagem literária procura produzir sentidos que extrapolem o simples significado dos signos estereotipados pela lexicalização convencional. $\mathrm{Na}$ impossibilidade de escapar de modo absoluto das imposições da linguagem comum, o poeta explora a sonoridade em todas as potencialidades do código.

Guimarães Rosa se ocupou com a questão, dizendo, numa entrevista, que gostaria de ser lembrado não como um revolucionário das palavras, e sim como um reacionário, por querer recuperar a força original da palavra, ainda confundida com a coisa.

O desejo do grande escritor condensa a vontade de muitos: combinar o pensamento lógico ao pensamento concreto-mítico do homem arcaico, encontrar na linguagem um objeto sensório, como faz a criança na primeira fase do aprendizado, provando as potencialidades, fazendo treinos de aprimoramento, antes de se servir dela como elemento de socialização e de comunicação com o outro.

Arvorei-me de narradora que dispõe corpo e mente a serviço da tessitura dos resíduos da memória depositária do olhar infantil, base para a fabulação criativa. Tatuei os personagens em meu próprio corpo com agulhas de afetos e pigmentos de perceptos.

A travessia chegou ao fim. O livro terminado. Não é um conto de fadas. Embora uma delas tenha sobrevoado cada linha do trabalho com todo zelo, destacando acertos e corrigindo erros. A história não tem moral. É um trabalho de impacto, que pretende alcançar a dúvida, faceando desajustes da sociedade. Transcende o pessoal e o biográfico. Não se destina à reconstituição do passado ou à recuperação das lembranças mas, sim, à tentativa de inscrever momentos e sensações difusas. Explodir o flash. Crivar a imagem.

Barthes definindo o haicai diz: "é um átomo de frase que anota um elemento tênue da vida 'real', presente, concomitante." Como o haicai, o livro surgirá menos que representação e mais como tentativa de captação da vida no instante 
que morre (carpe diem), de capturar o que há de infinito e perdurável no minúsculo presente cotidiano.

A história contada tem um preço. $\mathrm{O}$ preço de uma busca. $\mathrm{O}$ preço de uma espera. O preço de uma necessidade. Busca, espera, necessidade de quê... 


\section{Referências Bibliográficas}

AGAMBEN, G. “O que é contemporâneo?". In: O que é contemporâneo?

E outros ensaios. Chapecó: Argos, 2009.

ARFUCH, L. O espaço biográfico: dilemas da subjetividade. Trad. Paloma Vidal, Rio de janeiro: UERJ, 2010.

BARTHES, R. A Câmara Clara. Nota sobre a fotografia. Tradução Júlio Castañon Guimarães, Rio de Janeiro: Nova Fronteira, 1984.

BAUDELAIRE, C. "O Pintor da vida moderna". In:__. Sobre a Modernidade. São Paulo: Paz e Terra, 2007.

DELEUZE, G. “A literatura e a vida”. In:__ . Crítica e Clínica. São Paulo: Ed. 34, 1997.

"O Ato da Criação". Trad. José Marcos Macedo. Disponível em: $<$ http://intermidias.blogspot.com/2007/07/o-ato-de-criação-por-gillesdeleuze.html.> Acesso em 29 de fev. 2012.

DELEUZE, G.; GUATARI, F. "Pecepto, afecto e conceito". In: . O Que é a Filosofia. Trad. Bento Prado Jr. \& Alberto Alonso. São Paulo: Ed. 34.1992. "1837 - Acerca do ritornelo". In: Mil Platôs, Capitalismo e Esquizofrenia. Trad. Suely Rolnik, São Paulo: Ed. 34, 1997.

ECO, H. Pós-Escrito a o Nome da Rosa. Trad. Letizia Zini Antunes \& Alvaro Lorencini. Nova Fronteira: Rio de Janeiro, 1984.

ESTRADA, E. M. D. Devires autobiográficos: a atualidade das escritas de si. Rio de Janeiro: Nau. Ed. Puc-rio, 2009.

FAUSTO, B. História do Brasil. 13. ed. São Paulo: Edusp, 2008.

FOUCAULT, M. A Ordem do Discurso. Trad. Laura fraga de Almeida Sampaio. São Paulo: Edições Loyola, 1996. 
KLINGER, D. I. Escritas de si, escritas do outro: o retorno do amor a virada etnográfica. Rio de Janeiro: 7 Letras, 2007.

LACOUE-LABARTHE, P.; NANCY, J. L. "A exigência fragmentária”. Terceira Margem. Revista do Programa de Pós-Graduação em Ciência da Literatura da UFRJ, ano IX, número, 10, 2004.

LEVY, T. S. A Experiência do Fora, Blanchot, Foucault e Deleuze. Rio de Janeiro: Relumé Dumará, 2003.

MENDES, M. Poliedro. Rio de Janeiro: José Olypio, 1972.

PROUST, M. No Caminho de Swann. Trad. Fernando PY. São Paulo: Abril, 2010.

RAMOS, N. “Infância, TV”. In: Ó. São Paulo: Iluminuras, 2008.

SCHWARZ, R. Duas meninas. São Paulo: Companhia das Letras, 2006.

VERSIANI, D. B. Autoetnografias: conceitos alternativos em construção. Rio de Janeiro: 7 Letras, 2005. 